\title{
The release of cardiac troponin : when, where and how
}

Citation for published version (APA):

Jacobs, L. H. J. (2012). The release of cardiac troponin : when, where and how. [Doctoral Thesis, Maastricht University]. Universitaire Pers Maastricht. https://doi.org/10.26481/dis.20120203lj

Document status and date:

Published: 01/01/2012

DOI:

10.26481/dis.20120203lj

Document Version:

Publisher's PDF, also known as Version of record

\section{Please check the document version of this publication:}

- A submitted manuscript is the version of the article upon submission and before peer-review. There can be important differences between the submitted version and the official published version of record.

People interested in the research are advised to contact the author for the final version of the publication, or visit the DOI to the publisher's website.

- The final author version and the galley proof are versions of the publication after peer review.

- The final published version features the final layout of the paper including the volume, issue and page numbers.

Link to publication

\footnotetext{
General rights rights.

- You may freely distribute the URL identifying the publication in the public portal. please follow below link for the End User Agreement:

www.umlib.nl/taverne-license

Take down policy

If you believe that this document breaches copyright please contact us at:

repository@maastrichtuniversity.nl

providing details and we will investigate your claim.
}

Copyright and moral rights for the publications made accessible in the public portal are retained by the authors and/or other copyright owners and it is a condition of accessing publications that users recognise and abide by the legal requirements associated with these

- Users may download and print one copy of any publication from the public portal for the purpose of private study or research.

- You may not further distribute the material or use it for any profit-making activity or commercial gain

If the publication is distributed under the terms of Article $25 \mathrm{fa}$ of the Dutch Copyright Act, indicated by the "Taverne" license above, 


\section{The release of cardiac troponin when, where and how}


Cover illustration modified from "abstract fractal heart" @ Dreamstime.com Printed by: Datawyse Universitaire Pers Maastricht

ISBN: 9789461591142

(C) Copyright L.H.J. Jacobs, Maastricht 2012 


\section{The release of cardiac troponin when, where and how}

\section{Proefschrift}

ter verkrijging van de graad van doctor aan de Universiteit Maastricht, op gezag van de Rector Magnificus Prof. Mr. G.P.M.F. Mols volgens het besluit van het College van Decanen, in het openbaar te verdedigen op vrijdag 3 februari 2012 om 14.00 uur door

Leonardus Hubertus Jozef Jacobs

geboren op 15 mei 1980 te Venray

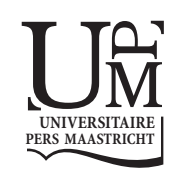




\section{Promotor}

Prof. dr. M.P. van Dieijen-Visser

\section{Copromotor}

Dr. W.K.W.H. Wodzig

\section{Beoordelingscommissie}

Prof. dr. C.P.M. Reutelingsperger (voorzitter)

Dr. P.O. Collinson (St. George's Hospital, London, UK)

Prof. dr. L. Hofstra (Cardiologie Centrum Utrecht)

Prof. dr. H.A. Katus (University of Heidelberg, D)

Prof. dr. L.J.C. van Loon

The research described in this thesis was supported by a grant of the Sint Annadal Stichting and the E.C. Noyons Stichting.

Financial support by the Dutch Heart Foundation and the E.C. Noyons Stichting for the publication of this thesis is gratefully acknowledged.

Roche Diagnostics, Abbott Diagnostics and AKSA Medical are also gratefully acknowledged for their financial support. 


\section{Contents}

$\begin{array}{lll}\text { Chapter } 1 \quad \text { General introduction } & 7\end{array}$

Chapter 2 Haemodialysis patients longitudinally assessed by highly sensitive cardiac troponin $\mathrm{T}$ and commercial cardiac troponin $\mathrm{T}$ and cardiac troponin I assays

Chapter 3 Highly sensitive troponin T versus conventional troponin $\mathrm{T}$ testing for risk stratification in patients presenting with acute dyspnoea to the emergency department

Chapter 4 Reference population and marathon runner sera assessed by highly sensitive cardiac troponin $\mathrm{T}$ and commercial cardiac troponin $\mathrm{T}$ and I assays

Chapter 5 Ischemia and mechanical stretch in cultured cardiomyocytes and their varying effects on cardiac troponin release and degradation

Chapter 6 Inflammation, overhydration and cardiac biomarkers in haemodialysis patients: a longitudinal study

Chapter 7 Renal dysfunction, hemodialysis, and the NTproBNP/BNP ratio

Chapter 8 General discussion

Summary

Samenvatting

Dankwoord

List of publications

Curriculum Vitae 



\section{CHAPTER 1}

\section{General introduction}




\section{Introduction}

Cardiovascular diseases accounted for about 30\% of all deaths in the Netherlands in 2009 and a significant part of these deaths (27\%) were a direct consequence of acute coronary syndromes (ACS). ${ }^{1}$ The ACS encompass a number of cardiac ischemic events, including unstable angina pectoris and ST-segment and non-STsegment elevation acute myocardial infarction (AMI). ${ }^{2}$ In order to initiate a timely and accurate therapeutic response it is important that a rapid diagnosis of ACS can be made. As the clinical symptoms associated with ACS, such as chest pain, dyspnea and nausea are non-specific, additional diagnostic techniques, such as electrocardiography (ECG) and cardiac biomarker measurements are required to accurately diagnose ACS.3, 4 Nowadays, the diagnosis of ischemic cardiac damage relies strongly on cardiac biomarker measurements as can be illustrated by the 2007 "universal definition of myocardial infarction", that was published by an ESC/ACCF/AHA/WHF taskforce, wherein guidelines for the diagnosis of AMI were described. ${ }^{4}$ According to these guidelines an AMI is diagnosed when an increase or decrease in cardiac biomarker concentrations, with at least 1 value above the 99th percentile of the upper reference limit (URL) is detected, in combination with evidence of myocardial ischemia, as detected, either by clinical symptoms, electrocardiographic changes or imaging evidence. ${ }^{4}$ The cardiac troponins (cTn) were marked as the cardiac biomarkers of choice and cardiac troponin $\mathrm{T}(\mathrm{cTnT})$ and cardiac troponin I (cTnI) have become the 'gold standard' for the detection of myocardial injury.

Nevertheless, elevated cTn concentrations have been found in conditions without any apparent signs of ischemic cardiac damage and these elevations can frustrate the diagnosis of ACS. This thesis is focused on addressing the diagnostic implications and the underlying mechanisms of these non-ACS related cTn elevations.

\section{The cardiac troponins: when and how are they released?}

The troponin complex consists of 3 proteins, troponin C (TnC), troponin I (TnI) and troponin $\mathrm{T}(\mathrm{TnT})$ that together with tropomyosin regulate the affinity of actin towards myosin during muscle contraction (Box 1). The troponin complex is 
present in all striated muscles, but different isoforms of troponin I and T exist in skeletal and cardiac tissue. This tissue specific expression of cardiac troponin I (cTnI) and cardiac troponin $\mathrm{T}(\mathrm{cTnT})$ isoforms within the heart has enabled the development of immunoassays that can specifically detect troponin originating from the heart.5, 6 Following an AMI, the release kinetics of cTnT and cTnI are roughly similar and concentrations begin to rise 3-6 hours after the onset of AMI and peak after 12-24 hours.7, 8 The release of cTnT is often marked (especially after early reperfusion) by a biphasic release pattern, where a peak value (after 12-24 hours) is followed by a "plateau phase" lasting about 48 hours after which cTnT values gradually decrease to pre AMI levels.9, 10 For cTnI no biphasic release pattern has been shown, and its release is characterized by an initial rise, directly followed by a gradual decrease to undetectable levels. Figure 1 visualizes the release kinetics of cTnT and cTnI following AMI.

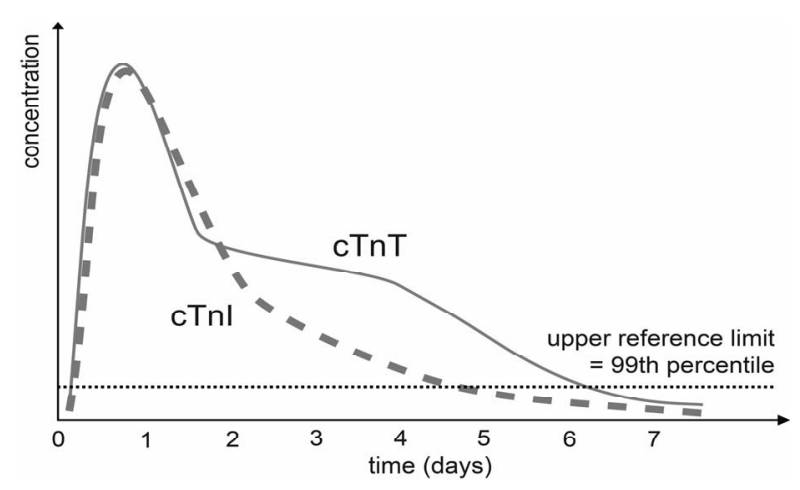

Figure 1. Typical Release kinetics of $\mathrm{cTnT}(-)$ and $\mathrm{cTnI}(--)$ seen after an acute myocardial infarction.

The typical biphasic release pattern of cTnT after AMI has been suggested to be the result of an initial release of cytoplasmic cTnT (first peak) followed by the release of the sarcomeric bound cTnT. ${ }^{11}$ Research, however, has shown similar cytosolic amounts of $\operatorname{cTnT}(6 \%-8 \%)^{9,12}$ and $\operatorname{cTnI}(8 \%)^{12}$ and one would expect that a biphasic release pattern would also be present for cTnI, so there may be other reasons for the different release kinetics. Another difference between the release kinetics of cTnT and cTnI pertains to the length of time they remain elevated after AMI. CTnT can remain elevated for several weeks, whereas cTnI drops to baseline 
levels after 5-7 days. ${ }^{8}$ Factors contributing to the prolonged elevation of cTnT relative to cTnI, include an increased serum half-life of cTnT (5-7 days) versus cTnI (3-5 days) and differences in the tissue content of cTnT (10.8 mg/g) and cTnI (4-6 $\mathrm{mg} / \mathrm{g}) .^{7} \mathrm{It}$ is important to note that $\mathrm{cTn}$ is released into the bloodstream in various molecular forms and complexes (visualized in figure 2).

Healthy cardiomyocyte

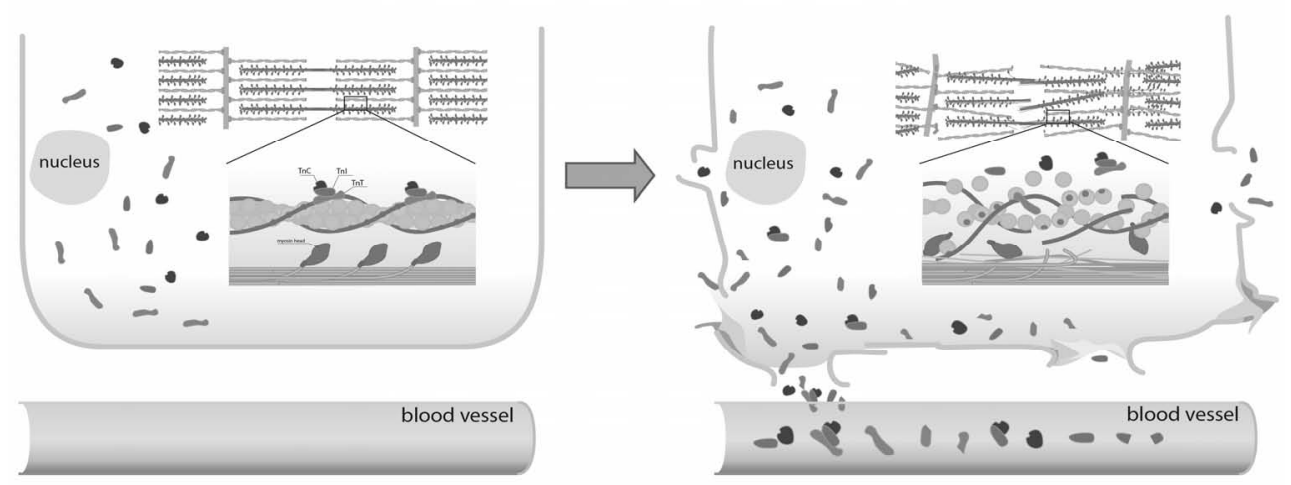

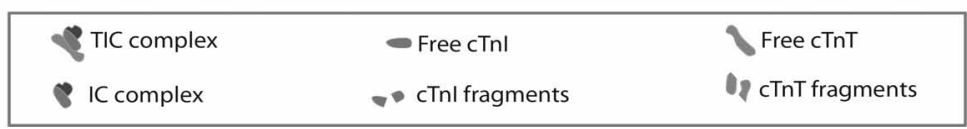

Figure 2. Visualization of the release of cardiac troponin from damaged cardiomyocytes. In response to (irreversible) cellular damage various molecular forms of cardiac troponin are released from the cytosol and from disintegrating. myofibrils.

For example, cTnI is mainly released into the circulation as a cTnT-cTnI-TnC (TIC) and cTnI-TnC (IC) complex and only a small fraction is released as free cTnI. ${ }^{13}, 14$ CTnT is thought to be released predominantly in the free form. ${ }^{13}$ Furthermore, both cTnT and cTnI can be targets of a wide variety of post-translational modifications, including specific degradation, phosphorylation and covalent complex formation. ${ }^{15-18}$ Some of these post-translational modifications are time-dependent, as demonstrated for the fragmentation of $\mathrm{cTnT}^{19}$ and $\mathrm{cTnI}^{20}$ after AMI. A better understanding of the release kinetics of the molecular forms of cTn in different conditions could lead to immunoassays with the ability to pinpoint the underlying causes of elevated cTn levels, enabling a more specific diagnosis and treatment. 


\section{Box 1 - The troponin complex and muscle contraction}

Skeletal and cardiac muscle cells contain several cylindrical organelles called myofibrils. These myofibrils are spread out from one end of the cell to the other. Myofibrils are organized into small contractile subunits called sarcomeres. Within these sarcomeres, two types of axially aligned filaments can slide over each other, whereby the length of the sarcomere decreases. During muscle contraction, this sliding action is initiated at the same time in all sarcomeres within the muscle cells and this, in effect, causes the shortening of the muscle cell. ${ }^{21}$ These "sliding filaments" are made up of thick filaments which consist mainly of the protein myosin, and thin filaments which consist of the protein actin. The molecular interaction between myosin and actin filaments is triggered by an increase in the intracellular Ca2+ concentration, whereby actin is pulled along myosin in an ATP hydrolysis driven reaction. ${ }^{22}$ Under resting conditions, when the intracellular Ca2+ concentration is low, myosin cannot interact with actin, due to steric hindrance of an actin bound protein called tropomyosin. ${ }^{23}$ In this resting state, tropomyosin is held in place over the myosin binding site by a complex of closely interacting regulatory proteins called the troponins. When muscle contraction is initiated and intracellular $\mathrm{Ca} 2+$ concentrations rise, the $\mathrm{Ca} 2+$ binds to the regulatory troponin complex and induces a structural change that causes tropomyosin to move away from the myosin binding site on actin, allowing myosin to interact with actin (reviewed in ${ }^{24}$ ). The three proteins constituting the troponin complex: troponin C (Calcium binding), troponin I (Inhibitory) and troponin $\mathrm{T}$ (Tropomyosin binding) each have a separate role in this regulatory process. Troponin $\mathrm{C}$ $(\mathrm{TnC})$ can bind $\mathrm{Ca} 2+$ and upon binding undergoes a conformational change, which increases its affinity towards troponin I (TnI) and induces a conformational change of TnI. This conformational change removes the bond between $\mathrm{TnI}$ and actin whereby tropomyosin is shifted away from the myosin binding sites of the actin molecules, allowing myosin to bind to actin. Troponin $\mathrm{T}$ structurally anchors the troponin complex to tropomyosin. ${ }^{25}$ The figure below (figure box 1) visualizes the role of the cardiac troponin complex in muscle contraction.

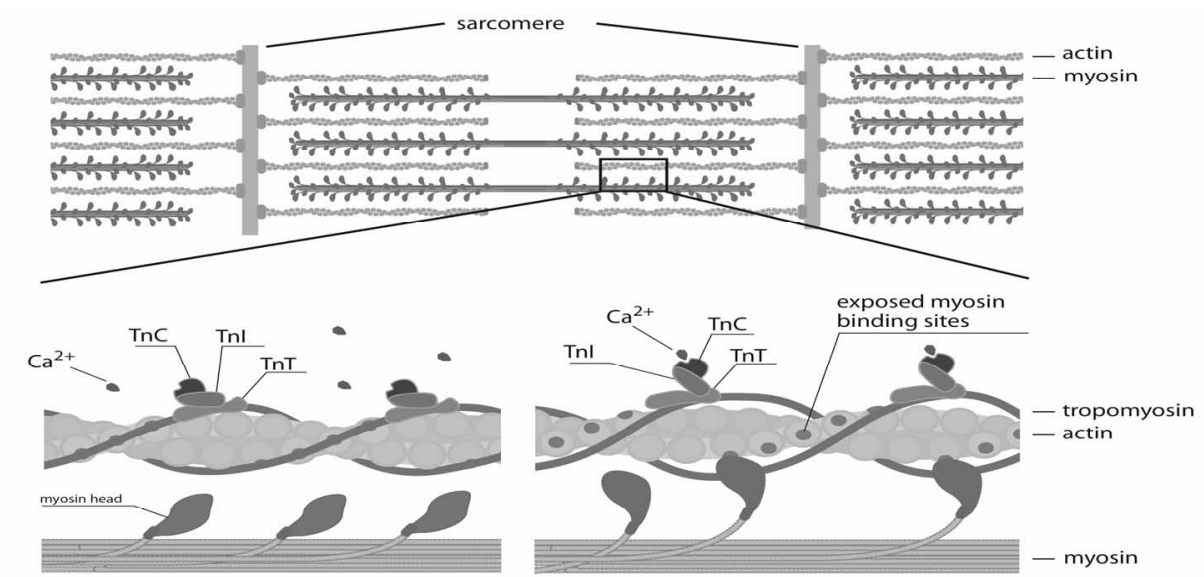

Figure box 1. Schematic representation of the structure and function of the troponin complex within the sarcomere. The left side of the figure shows the sarcomere in the relaxed state, the right side visualizes the conformational change of the troponin complex in response to calcium binding. 


\section{Troponins and the diagnosis of ACS}

Current guidelines describing the utilization of biochemical markers in $\mathrm{ACS}^{3}$ as well as the 2007 universal definition of myocardial infarction ${ }^{4}$ have firmly established the importance of cTn measurements for the diagnosis of ACS. As mentioned above, an AMI is diagnosed when an increase or decrease in cardiac biomarker concentrations (preferably cTn), above the $99^{\text {th }}$ percentile of the upper reference limit (URL) is detected, in combination with evidence of myocardial ischemia, as detected, either by clinical symptoms, electrocardiographic changes or imaging evidence. Additionally, the guidelines state that the cTn-assays should be able to measure the $99^{\text {th }}$ percentile concentrations with a coefficient of variation (CV) smaller than 10\% (Box 2). ${ }^{4}$ Ideally, blood samples for the measurements of cTn should be drawn on first assessment (after the onset of clinical symptoms) and 6-9 hours later in order to detect a rising or falling pattern. However, as is illustrated in figure 1, cTn levels can remain elevated for some time and the diagnostic window for diagnosing AMI can remain open for several days after the onset of symptoms (e.g. when a patients presents $>24$ hours after onset of symptoms).

Most of the studies investigating cTnT and cTnI elevations outside of AMI have been performed using immunoassays that lack sufficient analytical performance to accurately detect cTn concentrations in healthy subjects, either because the limit of detection (LOD) of the assay is higher than the reference concentrations or because the CV exceeds $10 \%$ at the 99 ${ }^{\text {th }}$ URL. ${ }^{26-28}$ Highly sensitive assays with the ability to accurately measure cTn values even in healthy subjects have been developed recently for $\mathrm{cTnT}^{29}$ and cTnI. ${ }^{30,31}$ The increased sensitivity may improve the prognostic power of cTn measurements and may enhance identification of subjects at risk. Indeed, two recent studies have shown the prognostic value of cTnT at previously undetectable levels in patients with stable coronary disease ${ }^{32}$ and with stable chronic heart failure. ${ }^{33}$ Moreover, cTnT values measured by a high sensitive cTnT assay (hs-cTnT) that were undetectable with the conventional assay were found to be associated with the extent of coronary atherosclerosis. ${ }^{34}$ 


\section{Box 2 - Analytical requirements for the cTn assays}

Determining a cut-off value for a diagnostic test can be difficult and various statistical, clinical, but also economical and logistical considerations are taken into account for determining the best cut-off point for classifying a positive or negative test result. With respect to the cTn measurements, a consensus was reached, stating that cTn concentrations can be considered elevated when the measurements exceed the $9^{\text {th }}$ percentile URL, with the prerequisite that they can be measured with a CV $<10 \% .^{3,4}$ What does this mean? Well, let's begin with the $99^{\text {th }}$ percentile URL. The $99^{\text {th }}$ percentile URL is the concentration below which $99 \%$ of subjects in a healthy population have their value, i.e. only $1 \%$ of all healthy subjects exceed this value. Figure box 2 a exemplifies this concept by showing the cTnT concentration measured in a population of 477 healthy subjects. Within this population $99 \%$ of all subjects have cTnT concentrations below $16 \mathrm{ng} / \mathrm{L}$ and therefore the $99^{\text {th }}$ percentile is set at $16 \mathrm{ng} / \mathrm{L}$. The requirement that this concentration should be measurable with a CV of less than $10 \%$ pertains to the analytical variation that is seen upon repeated measurements. Statistically, the $\mathrm{CV}$ is defined as the standard deviation divided by the mean. Figure box $2 \mathrm{~b}$ shows a precision profile for the hs-cTnT assay (Roche diagnostics, Mannheim Germany). To generate this profile we performed repeated measurement $(n=20)$ of 7 pooled serum samples, with cTnT concentrations varying between 2 and $19 \mathrm{ng} / \mathrm{L}$ and calculated the $\mathrm{CV}$ found for each of the samples. As can be seen in figure box 2, the CV decreases with increasing cTnT concentrations and from a concentration of $9 \mathrm{ng} / \mathrm{L}$ and upward the cTnT concentration can be measured with a CV of less than $10 \%$. As the $99^{\text {th }}$ URL (16 ng/L) lies above the $10 \%$ CV level $(9 \mathrm{ng} / \mathrm{l})$ it can be determined with the precision required by the current guidelines. . $^{3,4}$

a)

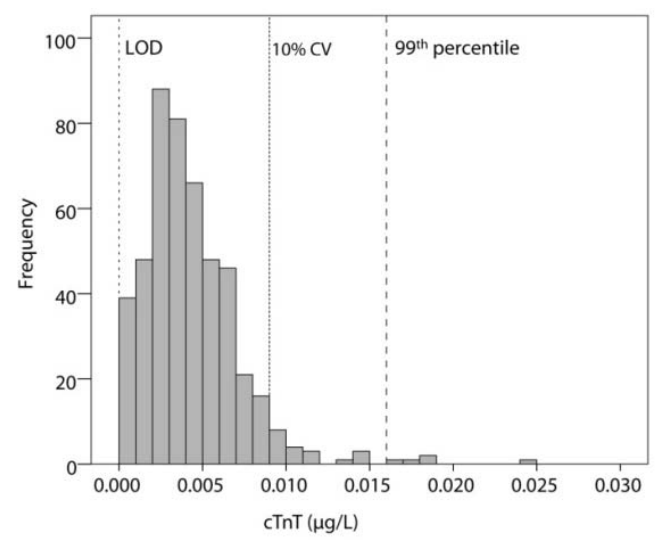

b)

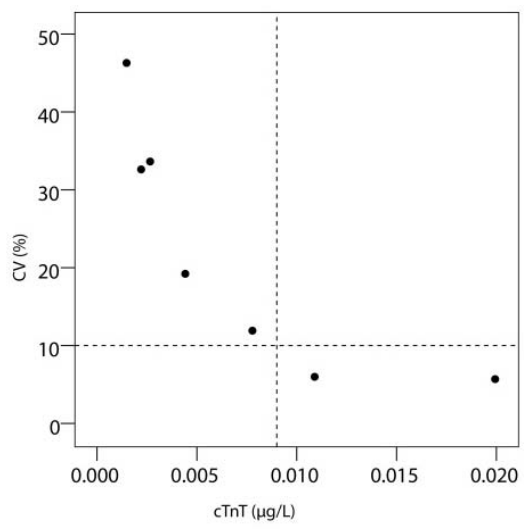

Figure box 2a \& 2 b

Figure 2a shows the cTnT concentrations measured with the hs-cTnT assay in a reference population of 477 healthy subjects (adapted from Jacobs et al.). ${ }^{35}$

Figure $\mathbf{2} \mathbf{b}$ shows the precision profile for the hs-cTnT assay (adapted from Mingels et al.). ${ }^{36}$ 


\section{Cardiac troponin elevations not related to AMI}

The release of the cTns is not limited to AMI and other forms of myocardial damage may result in elevated cTn levels. The occurrence of such non-AMI cTn elevations have been extensively reviewed 37,38 and are discussed in the current "Universal definition of myocardial infarction guidelines". 4 Table 1 outlines some of the pathological conditions describing cTnT elevations in the absence of overt ischemic disease. Obviously, the occurrence of these cTn elevations can interfere with the diagnosis of AMI and an understanding of the pathologies underlying these elevations can prevent unnecessary and costly interventions. The fact that these elevations occur outside of AMI does not mean that they are benign in nature and cTnI and cTnT elevations have been shown to be highly prognostic of adverse outcomes. For example, in acute ${ }^{39}$ and chronic heart failure (HF) patients, ${ }^{40-42}$ patients suffering from end stage renal disease (ESRD) ${ }^{43-45}$ and even in subjects without signs of cardiovascular disease, ${ }^{46,47}$ elevated cTn levels are associated with more severe disease and worse prognosis.

Table 1. Cardiac troponin elevations in the absence of overt ischemic heart disease

Cardiac contusion or trauma

Congestive heart failure (acute and chronic)

Rhabdomyolysis with cardiac involvement

Myocarditis

Tachy- or bradyarrhythmias

Aortic dissection and severe aortic valve disease

Coronary vasculitis, e.g. systemic lupus erythematosus, Kawasaki syndrome

Sepsis

Acute respiratory failure

Frequent defibrillator shocks

Cardiotoxic agents, e.g. anthracyclines, herceptin, carbon monoxide poisoning

Severe burns affecting $30 \%$ of body surface

Severe acute neurological diseases, e.g. stroke, trauma

Severe pulmonary embolism or pulmonary hypertension

Frequent defibrillator shocks

Renal failure / End stage renal disease

Extreme exertion / strenuous exercise

Table 1 is modified form Agewall et al. ${ }^{48}$ and Thygesen et al. ${ }^{49}$

Nonetheless, the elevated levels can be difficult to interpret by clinicians and can frustrate the diagnosis of AMI. Particularly prominent in the debate on cTn elevations outside of ACS are the elevations in ESRD patients and those subsequent to strenuous exercise, these are discussed in more detail below. 


\section{Cardiac troponin elevations in End Stage Renal Disease}

Patients with end-stage renal disease (ESRD) often suffer from cardiovascular complications and comorbidities. For example, 55\% of ESRD patients suffer from congestive heart failure (CHF), and cardiovascular diseases account for the majority of deaths among ESRD patients. ${ }^{50-52}$ It is, therefore, of great importance to diagnose the underlying cardiac pathologies and to provide accurate risk stratification in ESRD patients. As described above, the introduction of cTn has greatly improved the diagnosis and risk stratification of $\mathrm{ACS},{ }^{4}$ but in the setting of ESRD, cTn concentrations can be elevated in the absence of apparent cardiac damage or clinical symptoms. ${ }^{43,53-56}$ The exact frequency of these elevations varies somewhat between studies, depending on the patient inclusion criteria, the applied cut-off values and the troponin assay used. In general, cTnT has been found elevated more often than $\mathrm{cTnI}$ (roughly $53 \%$ for $\mathrm{cTnT}$ and $17 \%$ for $\mathrm{cTnI}$ as reviewed by Kanderian et al $)^{57}$ although recent publications, using more sensitive assays suggest that the frequency of cTnT and cTnI elevations are similar. 58,59

The underlying mechanisms behind these elevations have not been fully elucidated. The high incidence of coronary artery disease in ESRD patients ${ }^{50,51}$ and the close relationship between cTn levels and the severity of coronary artery disease ${ }^{56,60}$ make the presence of subclinical ischemic cardiac damage a possible cause of cTn elevations. In this respect, it is interesting to mention a study by DeFillipi et al. ${ }^{61}$ who compared elevated cTnT values in 23 ESRD patients, with evidence of myocardial ischemia gathered by means of cardiovascular magnetic resonance (CMR) with late gadolinium enhancement. ${ }^{61}$ This study found that only a very small number of patients with elevated cTnT had CMR evidence of myocardial damage ( $0 \%$ of patients with cTnT $<0.03 \mu \mathrm{g} / \mathrm{L}$ and $23 \%$ of patients with $\mathrm{cTnT}>0.07 \mu \mathrm{g} / \mathrm{L}){ }^{61}$ So, these patients, without known coronary artery disease and virtually no evidence of myocardial ischemia still had elevated cTnT values. Additionally, a recent study which used a highly sensitive cTnT assay found cTnT elevations at least once during a six-month period in all of the 32 ESRD patients under investigation, of which 15 did not have a history of cardiovascular disease. ${ }^{35}$ These findings, together with the lack of clinical symptoms, suggest there might be other than ischemia related reasons for the elevated levels of cTn. For example, the cTn half-life was shown to increase with the degree of renal impairment ${ }^{62}$ and the 
dialysis process itself can also have a direct effect on cTn concentrations. ${ }^{63}, 64$ Furthermore, Diris et al. ${ }^{65}$ have shown the presence of immunoreactive cTnT fragments, which are small enough to be cleared by the kidneys and which might accumulate in ESRD patients. Others, however, have found only intact cTnT in patients with kidney failure, ${ }^{66}$ and to date there is still a great deal of debate on the mechanisms underlying the cTn elevation in ESRD patients. Whatever the exact mechanism, the elevations should not be taken lightly as they are highly predictive for adverse cardiovascular events. ${ }^{43-45}$

Irrespective of the underlying mechanism, the presence of continuously elevated cTn concentrations can frustrate the diagnosis of AMI (eg. when ESRD patients present with clinical symptoms). The National Academy of Clinical Biochemistry (NACB) has recognized this issue and has published guidelines that address this issue. ${ }^{67}$ These guidelines suggest that for patients with chronically elevated concentrations of cTn, changes in cTn (>20\%) 6-9 hours after the onset of clinical symptoms are indicative of an AMI. To date, however, little is known about the analytical and biological variations of cTn in ESRD patients and $>20 \%$ changes might also occur in the absence of clinical symptoms.68, 69 The lack of detailed knowledge of the biological variation in ESRD patients, in combination with the likely increase in the frequency of chronically elevated cTnT as a result of more sensitive measurements call for further refinement of the current guidelines. As the highly sensitive cTn assays will enable a more accurate assessment of the biological variation, the use of serial measurement in order to detect abnormal changes in cTn values will likely be incorporated into these refinements.

\section{Cardiac troponin elevations after strenuous exercise}

Endurance exercise is generally seen as a healthy activity which can promote wellbeing, and prevent cardiovascular disease. ${ }^{70}$ Nonetheless, immediately after strenuous exercise, such as marathon running, markers of cardiac damage, like cTnT and cTnI can be detected in the bloodstream..$^{71-75}$ Obviously, these elevations can frustrate the diagnosis of AMI in athletes presenting to the emergency room with clinical symptoms of AMI and could subject them to unnecessary interventions and hospital admissions. 
To date it is unclear whether the elevations seen after strenuous exercise are benign in nature, or if they are suggestive of underlying cardiac pathologies. The fact that intensive exercise can lead to transient systolic and more persistent diastolic dysfunction of both the right and the left ventricle ${ }^{76}$ is suggestive of cardiac damage. Furthermore, a recent study showed that $12 \%$ of apparently healthy marathon runners had evidence of myocardial damage, as shown by CMR imaging and that this rate was 3 times higher than in age matched control subjects. ${ }^{77}$ On the other hand, investigations in a group of young Olympic endurance athletes showed that the long term consequences of intense endurance training was not associated with changes in left ventricular function or morphology, or with the occurrence of cardiovascular symptoms or events. ${ }^{78}$ So, with respect to the clinical findings it cannot be definitively concluded that strenuous exercise causes cardiomyocyte death and if the cTn elevations are associated with cardiac pathologies.

On the basis of the elevated cTn levels it is also difficult to conclude if there is irreversible cardiomyocyte death after strenuous exercise. As minimal cTn elevations are predictive of cardiovascular events in subjects without overt cardiovascular disease, ${ }^{47}$ and associated with the extent of coronary atherosclerosis $^{34}$ one might suspect that cTn elevations after exercise are not benign in nature. However, to the best of our knowledge there is no data that show if cTn elevations after strenuous exercise are associated with mortality. Moreover, recent data suggest that cTn elevations not only occur after strenuous exercise but also after low intensity workouts. For example, only 30 minutes of high intensity exercise $^{79}$ (running) and even walking 80 (albeit over long distances) can cause cTn elevations. An interesting study by Middleton et al., ${ }^{81}$ showed that release of cTnT during marathon running already occurs during the first hour of running. These elevations had disappeared to baseline levels at the completion of the race (or within 1 hour of completion) and in some patients the elevations returned several hours after the marathon. These data not only show that the timing of blood-draws is important to accurately assess the prevalence of cTn elevations after exercise, but also that the release kinetics of cTn elevations after exercise are markedly different than those seen after AMI. Compared to AMI, the cTn increases after exercise appear much earlier and the elevations return to baseline much faster. ${ }^{81,} 82$ The 
above mentioned findings question whether the cTn elevations after strenuous exercise are the result of irreversible cardiomyocyte damage.

\section{Release of cardiac troponin from reversibly damaged cardiomyocytes}

It has been hypothesized that the elevated levels of cTn seen after exercise are the result of a transient increase in the cardiomyocyte membrane permeability, resulting in the "leakage" of cytosolic cTn from reversibly damaged cardiomyocytes.82, 83 Figure 3 visualizes the hypothesis of cTn release from reversibly damaged cardiomyocytes. The exact mechanism behind the reversible release has not been elucidated although recently, Hickman et al. ${ }^{84}$ offered an interesting explanation for the release of cTn from viable, non-necrotic cardiomyocytes. According to their hypothesis, blebs can form on the plasma membrane of cardiomyocytes in response to ischemia. These blebs, can either be reabsorbed, or release their content into the circulation. When the blebs release their content, cTn levels in a patient's blood will rise, whilst the cardiomyocytes remain viable (if the ischemic damage is not too large). Irrespective of the mechanism, one should note that a specific cytosolic release of cTn could lead to differences in the molecular forms of cTn that are released upon reversible and irreversible damage. As was shown in figure 2 and its accompanying text, irreversible cellular damage of cardiomyocytes will not only induce the release of free cTnT and cTnI from the cytosol, but also of the different cTn complexes that are released from disintegrating myofibrils. Reversible cellular damage however, has been suggested to induce an exclusive release "leakage" of cytosolic (unbound) cTn. ${ }^{11,85}$ In addition to the presence or absence of myofibrillar cTn, there might also be differences in the presence of cleaved forms of cTn. As the cells are not irreversibly damaged, the release of cell-death related proteases (i.e. calpain and caspases) will likely be much less pronounced. Figure 3 also visualizes some of the potential differences in the released molecular forms of cTn after reversible and irreversible damage. 


\section{Healthy cardiomyocyte}
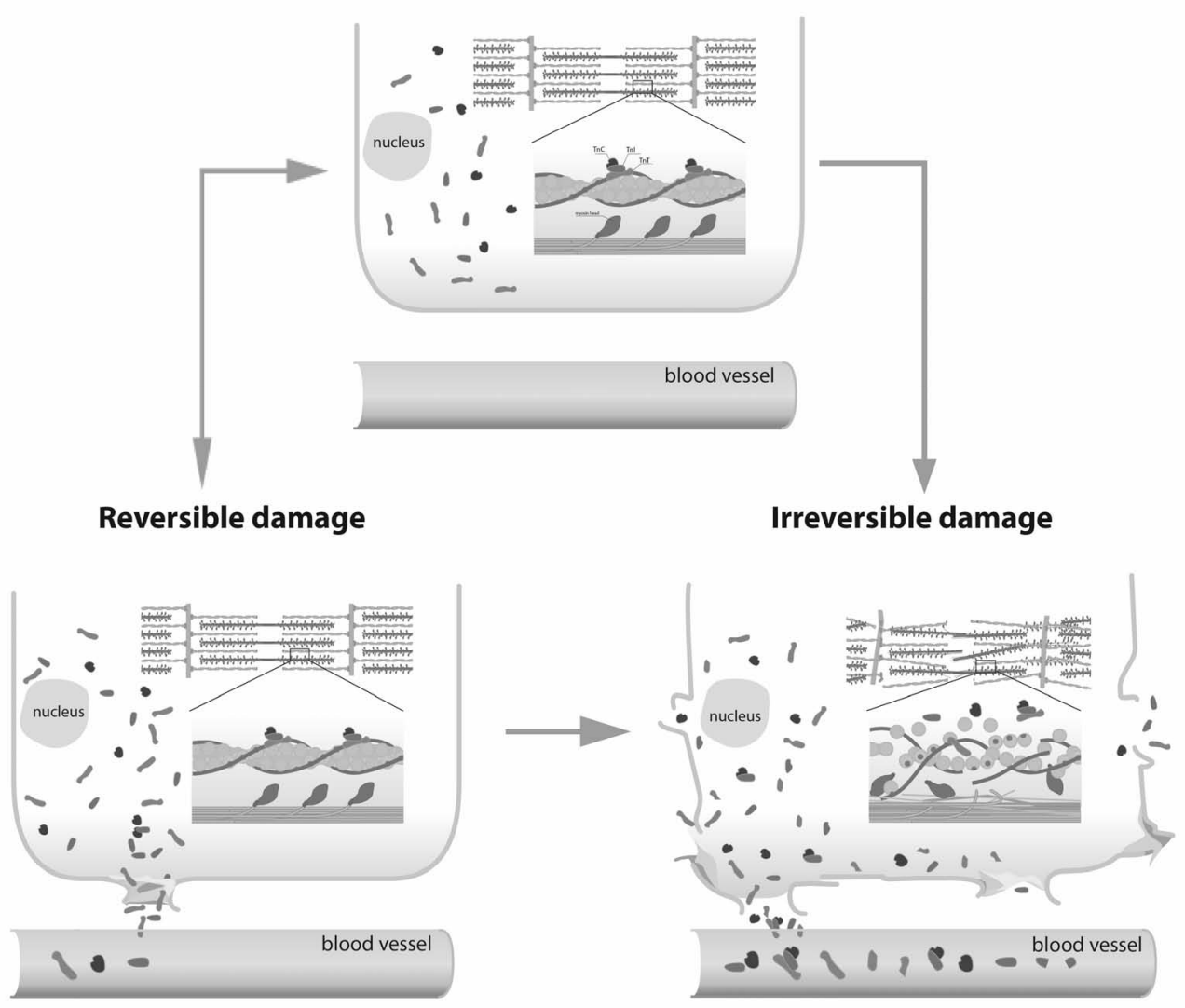

\begin{tabular}{|c|c|c|}
\hline TIC complex & Free cTnl & Free cTnT \\
\hline - IC complex & cTnl fragments & If cTnT fragments \\
\hline
\end{tabular}

Figure 3. Cardiac troponin release from reversibly versus irreversibly damaged cardiomyocytes.

a) Represents an intact healthy cardiomyocyte.

b) Shows a reversibly damaged cardiomyocyte, from which cTn can leak from the cytosol into the bloodstream.

c) Shows the release of cTn from irreversibly damaged cardiomyocyte, whereby cTn is released from both the cytosol and from disintegrating myofibrils. 


\section{Chapter 1}

Furthermore, the complexed forms of cTn might be more or less susceptible to proteolytic degradation than the free forms, as for example shown by Communal et al., who showed that caspase-3 cleaves cTnT when it is in complex with cTnI and TnC, but not as free cTnT. ${ }^{86}$ Some support for this hypothesis comes from the findings by Hessel et al. ${ }^{87}$ who showed the release of intact cTnI from viable cardiomyocytes by stimulation of stretch-responsive integrins. Conversely, irreversible cardiomyocyte damage, induced by metabolic inhibition with sodium azide, induced the simultaneous release of intact and fragmented forms of cTnI (and T). ${ }^{87,88}$ To date, no study has investigated the released molecular forms of the cTns after strenuous exercise and further work is needed to understand the mechanisms behind exercise induced release of cTn.

\section{Heart failure and the natriuretic peptides}

The damage to the heart that is sustained during an AMI, but also other disorders that can impair left ventricular myocardial function can lead to heart failure (HF). In HF there is a structural or functional cardiac disorder that impairs the ability of the ventricle to fill with or eject blood. ${ }^{89}$ In effect, the pump-function of the heart is impaired, which may lead to symptoms of dyspnea, fatigue and fluid retention. In the population over the age of 65 , the incidence of HF is about 1 per 100 and within this age group it is the leading cause of hospitalization in the United States. ${ }^{90}$

Considering the wide variety of causes underlying HF, the diagnosis and risk stratification in these patients is difficult. Over the years several advances have been made and the use of cardiac biomarkers, notably Brain Natriuretic Peptide (BNP) and N-terminal proBNP (NT-proBNP) has greatly advanced the physicians ability to identify patients with $\mathrm{HF}^{91}$ and to provide accurate risk stratification in this population. ${ }^{92}$ 


\section{The natriuretic peptides}

Physiologically, BNP plays an important role in the regulation of blood pressure; it induces natriuresis and diuresis, acts as a vasodilator and inhibits the reninangiotensine system..$^{93}$ The sysnthesis of BNP begins in the ventricular myocytes with the production of a precursor protein that is intracellularly converted to the prohormone proBNP. This prohormone is released into the bloodstream in response to increased hemodynamic stress (i.e. mechanical stretch seen during volume overload). Upon release into the circulation, the proBNP is split into the biologically active BNP and the inactive NT-proBNP, although recent data suggest that proBNP itself also remains present in the bloodstream. ${ }^{94} \mathrm{BNP}$ and NT-proBNP concentrations correlate with the severity of left ventricular dysfunction ${ }^{95}$ and congestive heart failure ${ }^{91,95}$ and are highly predictive of adverse events in patients who have suffered an AMI. ${ }^{96}$ Clinically, the use of BNP and NT-proBNP has been particularly successful in the diagnosis of heart failure in patients with acute dyspnea and in ruling out heart failure..$^{97} 98$ There are, however, various factors that can influence the BNP and NT-proBNP concentrations which can interfere with their diagnostic and prognostic potential. For example, NT-proBNP is influenced by age, gender and obesity ${ }^{99-101}$ and in particular by renal dysfunction. ${ }^{102,103}$

\section{Natriuretic peptide elevations in End Stage Renal Disease}

In patients with ESRD, the BNP and NT-proBNP concentrations are virtually always elevated above normal cut-off values. ${ }^{53,} 104 \mathrm{BNP}$ and NT-proBNP remain prognostic in ESRD patients, ${ }^{104}$ but the optimal cut-off values are significantly higher and the diagnostic potential is diminished. ${ }^{105}$

In ESRD there are several mechanisms that can explain (in part) the elevated BNP and NT-proBNP concentrations. In the first place there might be a lack of renal clearance as BNP and NT-proBNP have been shown to be inversely correlated to the glomerular filtration rate (reviewed in ${ }^{106}$ ). Interestingly, it is not clear if BNP and NT-proBNP are affected similarly by the reduction in renal clearance. Some reports mention that NT-proBNP is more strongly influenced by a decrease in renal function than $\mathrm{BNP},{ }^{102}$ whereas others state that they are equally dependent on the renal function for their clearance.103 It should be mentioned that the discrepancies between NT-proBNP and BNP increase with a decreasing 
glomerular filtration rate, as illustrated by the significantly higher NTproBNP/BNP ratios in patients with a decreased renal function. 102, 103, 107, 108 In particular in patients with a severely reduced renal function (eg. eGFR $<20$ ) the NT-proBNP/BNP seems to increase exponentially. ${ }^{102,} 107$ Recent reports in ESRD patients suggest that the NT-proBNP/BNP ratio increases even further in patients receiving hemodialysis. ${ }^{109}$ This increase in the NT-proBNP/BNP ratio might not be the sole result of renal clearance and other mechanism such as the extra-renal clearance by circulating type-C natriuretic peptide receptor and by neural endopeptidases ${ }^{110}$ may play a role. ${ }^{103}$ Specifically in ESRD patients, there are several other factors that can influence BNP or NT-proBNP concentrations. For example, the dialysis process itself may influence BNP and NT-proBNP concentrations, whereby, interestingly, some find elevated levels of NT-proBNP after dialysis ${ }^{64}$ whereas others find lower values. ${ }^{104}$ Other parameters, related to the dialysis treatment, such as a patient's volume status could also affect NTproBNP and BNP concentrations, ${ }^{111,112}$ whereby an increase in extracellular volume might induce left ventricular dilatation and subsequent increases in (NT-pro)BNP concentrations. More research is needed to understand the renal and extra-renal clearance of BNP and NT-proBNP and to identify ESRD related differences in the clearance or production of these peptides.

As BNP and NT-proBNP are still related to cardiovascular disease and all-cause mortality their measurement remains of importance for diagnosis and risk stratification in ESRD patients..$^{53,104}$ However, with the optimal cut-off values being significantly higher ${ }^{105}$ in ESRD patients it is of great importance that appropriate cut-off concentrations for BNP and NT-proBNP are developed.

\section{Outline of this thesis}

Cardiac troponin I and $\mathrm{T}$ are the most sensitive and accurate markers used in the diagnosis of acute myocardial infarction. Unfortunately, the cardiac troponins have been found elevated in a variety of physiological and pathological conditions without any apparent signs of AMI. The first part of this thesis focuses on these "non AMI" elevations of cardiac troponin. Chapter 2 investigates the presence of cardiac troponin elevations in clinically stable end-stage renal disease (ESRD) 
patients and describes the analytical and biological variations in cTnT and cTnI measurements in this population. Chapter 3 investigates the prognostic value of cTnT in patients presenting to the emergency room with acute dyspnea. Particular focus is placed on the added prognostic value of previously undetectable cTnT values that can now be measured with the hs-cTnT assay. Chapter 4 describes the presence of cTnT and cTnI elevations after strenuous exercise. In Chapter 5 the release characteristics of the cardiac troponins in response to simulated AMI and strenuous exercise are studied in cultured cardiomyocytes. The in-vitro study investigates how different cardiac stressors can induce the formation and release of different molecular forms of cTnT and cTnI.

The second part of this thesis focuses on BNP and NT-proBNP. Both these molecules are released from the cardiomyocytes upon increased cardiac wall stretch and are excellent diagnostics biomarkers for assessing heart failure. In ESRD patients there are several factors that influence NT-proBNP and BNP values and that can complicate the interpretation of elevated NT-proBNP values. Chapter 6 describes the influence of overhydration and inflammation on BNP and NTproBNP. Chapter 7 describes the highly increased NT-proBNP/BNP ratio that is found in ESRD patients and suggests that these markers are either cleared or produced in different amounts in patients receiving haemodialysis treatment.

The final chapter, Chapter 8 contains a general discussion of the results described in this thesis and gives directions towards future research.

\section{References}

1. Vaartjes I, van Dis I, Visseren F, Bots M. Hart- en vaatziekten in nederland 2010, cijfers over leefstijl- en risicofactoren, ziekte en sterfte. Den Haag: Nederlandse Hartstichting 2010.

2. Achar SA, Kundu S, Norcross WA. Diagnosis of acute coronary syndrome. Am Fam Physician. 2005;72:119-126

3. Morrow DA, Cannon CP, Jesse RL, Newby LK, Ravkilde J, Storrow AB, Wu AH, Christenson RH. National academy of clinical biochemistry laboratory medicine practice guidelines: Clinical characteristics and utilization of biochemical markers in acute coronary syndromes. Circulation. 2007; 115:e356-375

4. Thygesen K, Alpert JS, White HD. Universal definition of myocardial infarction. J Am Coll Cardiol. 2007;50:2173-2195

5. Katus HA, Remppis A, Looser S, Hallermeier K, Scheffold T, Kubler W. Enzyme linked immuno assay of cardiac troponin $\mathrm{t}$ for the detection of acute myocardial infarction in patients. $\mathrm{J} \mathrm{Mol} \mathrm{Cell}$ Cardiol. 1989;21:1349-1353 


\section{Chapter 1}

6. Cummins B, Auckland ML, Cummins P. Cardiac-specific troponin-i radioimmunoassay in the diagnosis of acute myocardial infarction. Am Heart J. 1987;113:1333-1344

7. Januzzi JL. Cardiac biomarkers in clinical practice. Sudbury, Mass.: Jones and Bartlett Publishers; 2011.

8. Collinson PO. Troponin t or troponin i or ck-mb (or none?). Eur Heart J. 1998;19 Suppl N:N16-24

9. Katus HA, Remppis A, Scheffold T, Diederich KW, Kuebler W. Intracellular compartmentation of cardiac troponin $\mathrm{t}$ and its release kinetics in patients with reperfused and nonreperfused myocardial infarction. Am J Cardiol. 1991;67:1360-1367

10. Mair J, Artner-Dworzak E, Lechleitner P, Smidt J, Wagner I, Dienstl F, Puschendorf B. Cardiac troponin $\mathrm{t}$ in diagnosis of acute myocardial infarction. Clin Chem. 1991;37:845-852

11. Remppis A, Scheffold T, Greten J, Haass M, Greten T, Kubler W, Katus HA. Intracellular compartmentation of troponin t: Release kinetics after global ischemia and calcium paradox in the isolated perfused rat heart. J Mol Cell Cardiol. 1995;27:793-803

12. Bleier J, Vorderwinkler KP, Falkensammer J, Mair P, Dapunt O, Puschendorf B, Mair J. Different intracellular compartmentations of cardiac troponins and myosin heavy chains: A causal connection to their different early release after myocardial damage. Clin Chem. 1998;44:1912-1918

13. Wu AH, Feng YJ, Moore R, Apple FS, McPherson PH, Buechler KF, Bodor G. Characterization of cardiac troponin subunit release into serum after acute myocardial infarction and comparison of assays for troponin $t$ and $i$. American association for clinical chemistry subcommittee on ctni standardization. Clin Chem. 1998;44:1198-1208

14. Katrukha AG, Bereznikova AV, Esakova TV, Pettersson K, Lovgren T, Severina ME, Pulkki K, Vuopio-Pulkki LM, Gusev NB. Troponin i is released in bloodstream of patients with acute myocardial infarction not in free form but as complex. Clin Chem. 1997;43:1379-1385

15. Labugger R, Organ L, Collier C, Atar D, Van Eyk JE. Extensive troponin i and t modification detected in serum from patients with acute myocardial infarction. Circulation. 2000;102:1221-1226

16. McDonough JL, Labugger R, Pickett W, Tse MY, MacKenzie S, Pang SC, Atar D, Ropchan G, Van Eyk JE. Cardiac troponin $\mathrm{i}$ is modified in the myocardium of bypass patients. Circulation. 2001;103:58-64.

17. McDonough JL, Van Eyk JE. Developing the next generation of cardiac markers: Disease-induced modifications of troponin i. Prog Cardiovasc Dis. 2004;47:207-216

18. Zhang Z, Biesiadecki BJ, Jin JP. Selective deletion of the nh2-terminal variable region of cardiac troponin $\mathrm{t}$ in ischemia reperfusion by myofibril-associated mu-calpain cleavage. Biochemistry. 2006;45:11681-11694

19. Michielsen EC, Diris JH, Kleijnen VW, Wodzig WK, Van Dieijen-Visser MP. Investigation of release and degradation of cardiac troponin $\mathrm{t}$ in patients with acute myocardial infarction. Clin Biochem. 2007;40:851-855

20. Madsen LH, Christensen G, Lund T, Serebruany VL, Granger CB, Hoen I, Grieg Z, Alexander JH, Jaffe AS, Van Eyk JE, Atar D. Time course of degradation of cardiac troponin i in patients with acute st-elevation myocardial infarction. The assent-2 troponin substudy. Circ Res. 2006;99:11411147

21. Guyton AC, Hall JE. Textbook of medical physiology. W.P. Saunders; 2000.

22. de Tombe PP. Cardiac myofilaments: Mechanics and regulation. J Biomech. 2003;36:721-730

23. Farah CS, Reinach FC. The troponin complex and regulation of muscle contraction. Faseb J. 1995;9:755-767

24. Kobayashi T, Jin L, de Tombe PP. Cardiac thin filament regulation. Pflugers Arch. 2008;457:37-46

25. Jin JP, Chong SM. Localization of the two tropomyosin-binding sites of troponin t. Arch Biochem Biophys. 2010;500:144-150

26. Panteghini M, Pagani F, Yeo KT, Apple FS, Christenson RH, Dati F, Mair J, Ravkilde J, Wu AH. Evaluation of imprecision for cardiac troponin assays at low-range concentrations. Clin Chem. 2004;50:327-332 
27. Giannitsis E, Katus HA. Comparison of cardiac troponin $t$ and troponin i assays--implications of analytical and biochemical differences on clinical performance. Clin Lab. 2004;50:521-528

28. Panteghini M. The new definition of myocardial infarction and the impact of troponin determination on clinical practice. Int J Cardiol. 2006;106:298-306

29. Giannitsis E, Kurz K, Hallermayer K, Jarausch J, Jaffe AS, Katus HA. Analytical validation of a high-sensitivity cardiac troponin $\mathrm{t}$ assay. Clin Chem. 2010;56:254-261

30. Todd J, Freese B, Lu A, Held D, Morey J, Livingston R, Goix P. Ultrasensitive flow-based immunoassays using single-molecule counting. Clin Chem. 2007;53

31. F.S. Apple MMM, D.P.Farris, S.A. Karimi, P.A. Simpson, L.T.Le. Serum 99th percentile reference value for the high sensitive singulex cardiac troponin i assay. Clinical Chemistry. 2009;55:A63

32. Omland T, de Lemos JA, Sabatine MS, Christophi CA, Rice MM, Jablonski KA, Tjora S, Domanski MJ, Gersh BJ, Rouleau JL, Pfeffer MA, Braunwald E. A sensitive cardiac troponin $t$ assay in stable coronary artery disease. $N$ Engl J Med. 2009;361:2538-2547

33. Latini R, Masson S, Anand IS, Missov E, Carlson M, Vago T, Angelici L, Barlera S, Parrinello G, Maggioni AP, Tognoni G, Cohn JN. Prognostic value of very low plasma concentrations of troponin $\mathrm{t}$ in patients with stable chronic heart failure. Circulation. 2007;116:1242-1249

34. Laufer EM, Mingels AM, Winkens MH, Joosen IA, Schellings MW, Leiner T, Wildberger JE, Narula J, Van Dieijen-Visser MP, Hofstra L. The extent of coronary atherosclerosis is associated with increasing circulating levels of high sensitive cardiac troponin t. Arterioscler Thromb Vasc Biol.2010; 30:1269-1275

35. Jacobs LH, van de Kerkhof J, Mingels AM, Kleijnen VW, van der Sande FM, Wodzig WK, Kooman JP, van Dieijen-Visser MP. Haemodialysis patients longitudinally assessed by highly sensitive cardiac troponin $\mathrm{t}$ and commercial cardiac troponin $\mathrm{t}$ and cardiac troponin $\mathrm{i}$ assays. Ann Clin Biochem. 2009;46:283-290

36. Mingels A, Jacobs L, Michielsen E, Swaanenburg J, Wodzig W, van Dieijen-Visser M. Reference population and marathon runner sera assessed by highly sensitive cardiac troponin $t$ and commercial cardiac troponin $\mathrm{t}$ and $\mathrm{i}$ assays. Clin Chem. 2009;55:101-108

37. Hamm CW, Giannitsis E, Katus HA. Cardiac troponin elevations in patients without acute coronary syndrome. Circulation. 2002;106:2871-2872

38. Kelley WE, Januzzi JL, Christenson RH. Increases of cardiac troponin in conditions other than acute coronary syndrome and heart failure. Clin Chem. 2009

39. Peacock WFt, De Marco T, Fonarow GC, Diercks D, Wynne J, Apple FS, Wu AH. Cardiac troponin and outcome in acute heart failure. N Engl J Med. 2008;358:2117-2126

40. Setsuta K, Seino Y, Ogawa T, Arao M, Miyatake Y, Takano T. Use of cytosolic and myofibril markers in the detection of ongoing myocardial damage in patients with chronic heart failure. Am J Med. 2002;113:717-722.

41. Miller WL, Hartman KA, Burritt MF, Grill DE, Jaffe AS. Profiles of serial changes in cardiac troponin $\mathrm{t}$ concentrations and outcome in ambulatory patients with chronic heart failure. Journal of the American College of Cardiology. 2009;54:1715-1721

42. Perna ER, Macin SM, Canella JP, Augier N, Stival JL, Cialzeta JR, Pitzus AE, Garcia EH, Obregon R, Brizuela M, Barbagelata A. Ongoing myocardial injury in stable severe heart failure: Value of cardiac troponin $\mathrm{t}$ monitoring for high-risk patient identification. Circulation. 2004;110:2376-2382

43. Sommerer C, Beimler J, Schwenger V, Heckele N, Katus HA, Giannitsis E, Zeier M. Cardiac biomarkers and survival in haemodialysis patients. Eur J Clin Invest. 2007;37:350-356

44. Khan NA, Hemmelgarn BR, Tonelli M, Thompson CR, Levin A. Prognostic value of troponin $t$ and i among asymptomatic patients with end-stage renal disease: A meta-analysis. Circulation. 2005;112:3088-3096

45. Apple FS, Murakami MM, Pearce LA, Herzog CA. Predictive value of cardiac troponin i and $t$ for subsequent death in end-stage renal disease. Circulation. 2002;106:2941-2945. 


\section{Chapter 1}

46. Zethelius B, Johnston N, Venge P. Troponin i as a predictor of coronary heart disease and mortality in 70-year-old men: A community-based cohort study. Circulation. 2006;113:1071-1078

47. Otsuka T, Kawada T, Ibuki C, Seino Y. Association between high-sensitivity cardiac troponin $t$ levels and the predicted cardiovascular risk in middle-aged men without overt cardiovascular disease. Am Heart J.159:972-978

48. Agewall S, Giannitsis E, Jernberg T, Katus H. Troponin elevation in coronary vs. Non-coronary disease. Eur Heart $J$.

49. Thygesen K, Mair J, Katus H, Plebani M, Venge P, Collinson P, Lindahl B, Giannitsis E, Hasin Y, Galvani M, Tubaro M, Alpert JS, Biasucci LM, Koenig W, Mueller C, Huber K, Hamm C, Jaffe AS. Recommendations for the use of cardiac troponin measurement in acute cardiac care. Eur Heart J.

50. U.S. Renal data system, usrds 2007 annual data report: Atlas of chronic kidney disease and endstage renal disease in the united states, national institutes of health, national institute of diabetes and digestive and kidney diseases, bethesda, md, 2007. 2007:192-208

51. National Institutes of Health; National Institute of Diabetes and Digestive and Kidney Diseases; Bethesda M. U.S. Renal Data System, USRDS 2007 Annual Data Report: Atlas of Chronic Kidney Disease and End-Stage Renal Disease in the United States. 2007:138-154

52. Herzog CA, Ma JZ, Collins AJ. Poor long-term survival after acute myocardial infarction among patients on long-term dialysis. N Engl J Med. 1998;339:799-805

53. Apple FS, Murakami MM, Pearce LA, Herzog CA. Multi-biomarker risk stratification of n-terminal pro-b-type natriuretic peptide, high-sensitivity c-reactive protein, and cardiac troponin $\mathrm{t}$ and $\mathrm{i}$ in end-stage renal disease for all-cause death. Clin Chem. 2004;50:2233-2235

54. Havekes B, van Manen JG, Krediet RT, Boeschoten EW, Vandenbroucke JP, Dekker FW. Serum troponin $\mathrm{t}$ concentration as a predictor of mortality in hemodialysis and peritoneal dialysis patients. Am J Kidney Dis. 2006;47:823-829

55. Aviles RJ, Askari AT, Lindahl B, Wallentin L, Jia G, Ohman EM, Mahaffey KW, Newby LK, Califf RM, Simoons ML, Topol EJ, Berger P, Lauer MS. Troponin $t$ levels in patients with acute coronary syndromes, with or without renal dysfunction. N Engl J Med. 2002;346:2047-2052.

56. deFilippi C, Wasserman S, Rosanio S, Tiblier E, Sperger H, Tocchi M, Christenson R, Uretsky B, Smiley M, Gold J, Muniz H, Badalamenti J, Herzog C, Henrich W. Cardiac troponin t and c-reactive protein for predicting prognosis, coronary atherosclerosis, and cardiomyopathy in patients undergoing long-term hemodialysis. Jama. 2003;290:353-359

57. Kanderian AS, Francis GS. Cardiac troponins and chronic kidney disease. Kidney Int. 2006;69:11121114

58. Kumar N, Michelis MF, Devita MV, Panagopoulos G, Rosenstock JL. Troponin i levels in asymptomatic patients on haemodialysis using a high-sensitivity assay. Nephrol Dial Transplant. 2010

59. Hickman PE, Koerbin G, Southcott E, Tate J, Dimeski G, Carter A, McGill D, Talaulikar G, Potter JM. Newer cardiac troponin i assays have similar performance to troponin $t$ in patients with endstage renal disease. Ann Clin Biochem. 2007;44:285-289

60. Ooi DS, Isotalo PA, Veinot JP. Correlation of antemortem serum creatine kinase, creatine kinase$\mathrm{mb}$, troponin $\mathrm{i}$, and troponin $\mathrm{t}$ with cardiac pathology. Clin Chem. 2000;46:338-344

61. deFilippi CR, Thorn EM, Aggarwal M, Joy A, Christenson RH, Duh SH, Jeudy J, Beache G. Frequency and cause of cardiac troponin t elevation in chronic hemodialysis patients from study of cardiovascular magnetic resonance. Am J Cardiol. 2007;100:885-889

62. Wiessner R, Hannemann-Pohl K, Ziebig R, Grubitzsch H, Hocher B, Vargas-Hein O, Lun A, Schimke I, Liefeldt L. Impact of kidney function on plasma troponin concentrations after coronary artery bypass grafting. Nephrol Dial Transplant. 2007

63. Montagnana M, Lippi G, Tessitore N, Salvagno GL, Targher G, Gelati M, Lupo A, Guidi GC. Effect of hemodialysis on traditional and innovative cardiac markers. J Clin Lab Anal. 2008;22:59-65 
64. Sommerer C, Heckele S, Schwenger V, Katus HA, Giannitsis E, Zeier M. Cardiac biomarkers are influenced by dialysis characteristics. Clin Nephrol. 2007;68:392-400

65. Diris JH, Hackeng CM, Kooman JP, Pinto YM, Hermens WT, Van Dieijen-Visser MP. Impaired renal clearance explains elevated troponin $\mathrm{t}$ fragments in hemodialysis patients. Circulation. 2004;109:23-25

66. Fahie-Wilson MN, Carmichael DJ, Delaney MP, Stevens PE, Hall EM, Lamb EJ. Cardiac troponin t circulates in the free, intact form in patients with kidney failure. Clin Chem. 2006;52:414-420

67. Wu AH, Jaffe AS, Apple FS, Jesse RL, Francis GL, Morrow DA, Newby LK, Ravkilde J, Tang WH, Christenson RH, Cannon CP. National academy of clinical biochemistry laboratory medicine practice guidelines: Use of cardiac troponin and b-type natriuretic peptide or n-terminal prob-type natriuretic peptide for etiologies other than acute coronary syndromes and heart failure. Clin Chem. 2007;53:2086-2096

68. Roberts MA, Fernando D, Macmillan N, Proimos G, Bach LA, Power DA, Ratnaike S, Ierino FL. Single and serial measurements of cardiac troponin i in asymptomatic patients on chronic hemodialysis. Clin Nephrol. 2004;61:40-46

69. Miller WL, Hartman KA, Burritt MF, Grill DE, Rodeheffer RJ, Burnett JC, Jr., Jaffe AS. Serial biomarker measurements in ambulatory patients with chronic heart failure: The importance of change over time. Circulation. 2007;116:249-257

70. Thompson PD, Franklin BA, Balady GJ, Blair SN, Corrado D, Estes NA, 3rd, Fulton JE, Gordon NF, Haskell WL, Link MS, Maron BJ, Mittleman MA, Pelliccia A, Wenger NK, Willich SN, Costa F. Exercise and acute cardiovascular events placing the risks into perspective: A scientific statement from the american heart association council on nutrition, physical activity, and metabolism and the council on clinical cardiology. Circulation. 2007;115:2358-2368

71. Scharhag J, Herrmann M, Urhausen A, Haschke M, Herrmann W, Kindermann W. Independent elevations of n-terminal pro-brain natriuretic peptide and cardiac troponins in endurance athletes after prolonged strenuous exercise. Am Heart J. 2005;150:1128-1134

72. Kratz A, Lewandrowski KB, Siegel AJ, Chun KY, Flood JG, Van Cott EM, Lee-Lewandrowski E. Effect of marathon running on hematologic and biochemical laboratory parameters, including cardiac markers. Am J Clin Pathol. 2002;118:856-863

73. Fortescue EB, Shin AY, Greenes DS, Mannix RC, Agarwal S, Feldman BJ, Shah MI, Rifai N, Landzberg MJ, Newburger JW, Almond CS. Cardiac troponin increases among runners in the boston marathon. Ann Emerg Med. 2007;49:137-143, 143 e131

74. Leers MP, Schepers R, Baumgarten R. Effects of a long-distance run on cardiac markers in healthy athletes. Clin Chem Lab Med. 2006;44:999-1003

75. Michielsen EC, Wodzig WK, Van Dieijen-Visser MP. Cardiac troponin t release after prolonged strenuous exercise - a review. Sports Med. 2008;38:425-435

76. Neilan TG, Yoerger DM, Douglas PS, Marshall JE, Halpern EF, Lawlor D, Picard MH, Wood MJ. Persistent and reversible cardiac dysfunction among amateur marathon runners. Eur Heart J. 2006;27:1079-1084

77. Breuckmann F, Mohlenkamp S, Nassenstein K, Lehmann N, Ladd S, Schmermund A, Sievers B, Schlosser T, Jockel KH, Heusch G, Erbel R, Barkhausen J. Myocardial late gadolinium enhancement: Prevalence, pattern, and prognostic relevance in marathon runners. Radiology. 2009;251:50-57

78. Roberts MA, MacMillan N, Hare DL, Ratnaike S, Sikaris K, Fraenkel MB, Ierino FL. Cardiac troponin levels in asymptomatic patients on the renal transplant waiting list. Nephrology (Carlton). 2006;11:471-476

79. Shave R, Ross P, Low D, George K, Gaze D. Cardiac troponin i is released following high-intensity short-duration exercise in healthy humans. Int J Cardiol. 2010;145:337-339 


\section{Chapter 1}

80. Eijsvogels T, George K, Shave R, Gaze D, Levine BD, Hopman MT, Thijssen DH. Effect of prolonged walking on cardiac troponin levels. Am J Cardiol.105:267-272

81. Middleton N, George K, Whyte G, Gaze D, Collinson P, Shave R. Cardiac troponin t release is stimulated by endurance exercise in healthy humans. J Am Coll Cardiol. 2008;52:1813-1814

82. Neumayr G, Pfister R, Mitterbauer G, Maurer A, Gaenzer H, Sturm W, Hoertnagl H. Effect of the "race across the alps" in elite cyclists on plasma cardiac troponins i and t. Am J Cardiol. 2002;89:484486

83. Shave R, George K, Gaze D. The influence of exercise upon cardiac biomarkers: A practical guide for clinicians and scientists. Curr Med Chem. 2007;14:1427-1436

84. Hickman PE, Potter JM, Aroney C, Koerbin G, Southcott E, Wu AH, Roberts MS. Cardiac troponin may be released by ischemia alone, without necrosis. Clinica chimica acta; international journal of clinical chemistry. 2010;411:318-323

85. Neumayr G, Pfister R, Mitterbauer G, Eibl G, Hoertnagl H. Effect of competitive marathon cycling on plasma $\mathrm{n}$-terminal pro-brain natriuretic peptide and cardiac troponin $\mathrm{t}$ in healthy recreational cyclists. Am J Cardiol. 2005;96:732-735

86. Communal C, Sumandea M, de Tombe P, Narula J, Solaro RJ, Hajjar RJ. Functional consequences of caspase activation in cardiac myocytes. Proc Natl Acad Sci U S A. 2002;99:6252-6256.

87. Hessel MH, Atsma DE, van der Valk EJ, Bax WH, Schalij MJ, van der Laarse A. Release of cardiac troponin i from viable cardiomyocytes is mediated by integrin stimulation. Pflugers Arch. 2008;455:979-986

88. Hessel MH, Michielsen EC, Atsma DE, Schalij MJ, van der Valk EJ, Bax WH, Hermens WT, van Dieijen-Visser MP, van der Laarse A. Release kinetics of intact and degraded troponin $i$ and $t$ after irreversible cell damage. Exp Mol Pathol. 2008

89. Hunt SA. Acc/aha 2005 guideline update for the diagnosis and management of chronic heart failure in the adult: A report of the american college of cardiology/american heart association task force on practice guidelines (writing committee to update the 2001 guidelines for the evaluation and management of heart failure). J Am Coll Cardiol. 2005;46:e1-82

90. Lloyd-Jones DM, Larson MG, Leip EP, Beiser A, D'Agostino RB, Kannel WB, Murabito JM, Vasan RS, Benjamin EJ, Levy D. Lifetime risk for developing congestive heart failure: The framingham heart study. Circulation. 2002;106:3068-3072

91. Maisel AS, Krishnaswamy P, Nowak RM, McCord J, Hollander JE, Duc P, Omland T, Storrow AB, Abraham WT, Wu AH, Clopton P, Steg PG, Westheim A, Knudsen CW, Perez A, Kazanegra R, Herrmann HC, McCullough PA. Rapid measurement of b-type natriuretic peptide in the emergency diagnosis of heart failure. N Engl J Med. 2002;347:161-167.

92. Christ M, Thuerlimann A, Laule K, Klima T, Hochholzer W, Perruchoud AP, Mueller C. Long-term prognostic value of b-type natriuretic peptide in cardiac and non-cardiac causes of acute dyspnoea. Eur J Clin Invest. 2007;37:834-841

93. Levin ER, Gardner DG, Samson WK. Natriuretic peptides. N Engl J Med. 1998;339:321-328

94. Lam CS, Burnett JC, Jr., Costello-Boerrigter L, Rodeheffer RJ, Redfield MM. Alternate circulating pro-b-type natriuretic peptide and b-type natriuretic peptide forms in the general population. $\mathrm{J} \mathrm{Am}$ Coll Cardiol. 2007;49:1193-1202

95. Wieczorek SJ, Wu AH, Christenson R, Krishnaswamy P, Gottlieb S, Rosano T, Hager D, Gardetto N, Chiu A, Bailly KR, Maisel A. A rapid b-type natriuretic peptide assay accurately diagnoses left ventricular dysfunction and heart failure: A multicenter evaluation. Am Heart J. 2002;144:834-839.

96. Omland T, Persson A, Ng L, O'Brien R, Karlsson T, Herlitz J, Hartford M, Caidahl K. N-terminal pro-b-type natriuretic peptide and long-term mortality in acute coronary syndromes. Circulation. 2002;106:2913-2918. 
97. Hobbs FD, Davis RC, Roalfe AK, Hare R, Davies MK, Kenkre JE. Reliability of n-terminal pro-brain natriuretic peptide assay in diagnosis of heart failure: Cohort study in representative and high risk community populations. Bmj. 2002;324:1498

98. Januzzi J, James L., Camargo CA, Anwaruddin S, Baggish AL, Chen AA, Krauser DG, Tung R, Cameron R, Nagurney JT. The n-terminal pro-bnp investigation of dyspnea in the emergency department (pride) study. The American Journal of Cardiology. 2005;95:948-954

99. Maisel A. B-type natriuretic peptide levels: A potential novel "white count" for congestive heart failure. J Card Fail. 2001;7:183-193.

100. Wang TJ, Larson MG, Levy D, Leip EP, Benjamin EJ, Wilson PW, Sutherland P, Omland T, Vasan RS. Impact of age and sex on plasma natriuretic peptide levels in healthy adults. Am J Cardiol. 2002;90:254-258.

101. Mehra MR, Uber PA, Park MH, Scott RL, Ventura HO, Harris BC, Frohlich ED. Obesity and suppressed b-type natriuretic peptide levels in heart failure. Journal of the American College of Cardiology. 2004;43:1590-1595

102. Vickery S, Price CP, John RI, Abbas NA, Webb MC, Kempson ME, Lamb EJ. B-type natriuretic peptide (bnp) and amino-terminal probnp in patients with ckd: Relationship to renal function and left ventricular hypertrophy. Am J Kidney Dis. 2005;46:610-620

103. van Kimmenade RR, Januzzi JL, Jr., Bakker JA, Houben AJ, Rennenberg R, Kroon AA, Crijns HJ, van Dieijen-Visser MP, de Leeuw PW, Pinto YM. Renal clearance of b-type natriuretic peptide and amino terminal pro-b-type natriuretic peptide a mechanistic study in hypertensive subjects. J Am Coll Cardiol. 2009;53:884-890

104. Madsen LH, Ladefoged S, Corell P, Schou M, Hildebrandt PR, Atar D. N-terminal pro brain natriuretic peptide predicts mortality in patients with end-stage renal disease in hemodialysis. Kidney Int. 2007;71:548-554

105. Pimenta J, Sampaio F, Martins P, Carvalho B, Rocha-Goncalves F, Ferreira A, Bettencourt P. Aminoterminal b-type natriuretic peptide (nt-probnp) in end-stage renal failure patients on regular hemodialysis: Does it have diagnostic and prognostic implications? Nephron Clin Pract. 2009;111:c182-188

106. DeFilippi C, van Kimmenade RR, Pinto YM. Amino-terminal pro-b-type natriuretic peptide testing in renal disease. Am J Cardiol. 2008;101:82-88

107. Srisawasdi P, Vanavanan S, Charoenpanichkit C, Kroll MH. The effect of renal dysfunction on bnp, nt-probnp, and their ratio. Am J Clin Pathol. 2010;133:14-23

108. Kemperman H, van den Berg M, Kirkels H, de Jonge N. B-type natriuretic peptide (bnp) and nterminal probnp in patients with end-stage heart failure supported by a left ventricular assist device. Clin Chem. 2004;50:1670-1672

109. Jacobs LH, Mingels AM, Wodzig WK, van Dieijen-Visser MP, Kooman JP, Srisawasdi P, Vanavanan S, Charoenpanichkit C, Kroll M. Renal dysfunction, hemodialysis, and the ntprobnp/bnp ratio. Am J Clin Pathol. 2010;134:516-517

110. Martinez-Rumayor A, Richards AM, Burnett JC, Januzzi JL, Jr. Biology of the natriuretic peptides. Am J Cardiol. 2008;101:3-8

111. Booth J, Pinney J, Davenport A. N-terminal probnp--marker of cardiac dysfunction, fluid overload, or malnutrition in hemodialysis patients? Clin J Am Soc Nephrol. 2010;5:1036-1040

112. Jacobs LH, van de Kerkhof JJ, Mingels AM, Passos VL, Kleijnen VW, Mazairac AH, van der Sande FM, Wodzig WK, Konings CJ, Leunissen KM, van Dieijen-Visser MP, Kooman JP. Inflammation, overhydration and cardiac biomarkers in haemodialysis patients: A longitudinal study. Nephrol Dial Transplant. 2010;25:243-248 



\title{
CHAPTER 2
}

\section{Haemodialysis patients longitudinally assessed by highly sensitive cardiac troponin $\mathrm{T}$ and commercial cardiac troponin $\mathrm{T}$ and cardiac troponin $\mathrm{I}$ assays}

\begin{abstract}
SUMMARY
Background: Elevated cardiac troponin ( $(\mathrm{Tn})$ concentrations predict an increased mortality in patients suffering from end stage renal disease (ESRD). This study compares the performance of a pre-commercial high-sensitive cTnT assay (hs-cTnT) with two contemporary cTn assays in detecting cTn elevations in ESRD patients during a 6 month follow-up.

Methods: 32 ESRD patients were followed for 6 months, during which cTn concentrations were assessed every 2 months. Baseline biomarker concentrations were compared to those in a simultaneously measured reference population of 501 healthy subjects.

Results: During follow-up 26 (81\%), 32 (100\%) and 9 (28\%) of the patients showed elevated cTn concentrations according to the current $c \operatorname{Tn} T$, the $h s-c \operatorname{Tn} T$ and the $c \operatorname{Tn} I$ assays, respectively. The range of concentrations measured within each patient had a median (IQR) magnitude of $0.03 \mu g / L(0.02-0.06), 0.017 \mu g / L(0.011-0.029)$ and 0.011 $\mu g / L(0-0.017)$ according to aforementioned assays.

Conclusion: According to hs-cTnT assay, all of the ESRD patients had elevated cTnT concentrations at least once during the follow-up. As elevated cTn concentrations are highly prognostic of adverse events, the use of serial measurements has thus identified additional patients at risk for such events. The fact that we find cTn concentrations to be higher in patients with a history of cardiac disease is in line with this. Additional studies in ESRD patients are needed to investigate the added diagnostic and prognostic value of the very low cTnT concentrations and variations only detected by the hs-cTnT assay.
\end{abstract}




\section{Introduction}

Patients suffering from end-stage renal disease (ESRD) have a markedly reduced lifespan. Overall, the life expectancy of patients undergoing dialysis is about 4 times as low as for the general population. ${ }^{1}$ The main cause of death in these patients is accounted for by cardiovascular events and over $55 \%$ of patients on dialysis suffer from congestive heart failure.1, 2 Considering this high incidence of cardiovascular complications, there is a need for accurate and sensitive biomarkers which can be used for diagnosis and risk stratification in ESRD patients. Over the years, the cardiac troponins (cTn) have proven to be accurate and sensitive markers for assessing ischaemic cardiac damage and predicting cardiovascular death in ESRD patients. ${ }^{3,4}$ Nonetheless, cTn concentrations can be elevated in the absence of apparent cardiac damage or clinical symptoms (as reviewed in 5,6) and might be influenced by a decreased renal clearance in patients with severe renal disease.7, 8 As the diagnosis of acute myocardial infarction (AMI) has been defined as: a rise and/or fall of cardiac markers - preferably cTnT or cTnI - detected with at least one value above the $99^{\text {th }}$ percentile limit of the reference population and should be associated with clinical, electro-cardiographic or imaging findings, ${ }^{9,}{ }^{10}$ such cTn elevations can impede the diagnosis of an acute myocardial infarction (AMI) (eg. when ESRD patients are presenting with clinical symptoms). Recent National Academy of Clinical Biochemistry (NACB) guidelines have addressed this issue and suggest that for patients with chronically elevated concentrations of cTn, changes in cTn (>20\%) 6-9 hours after the onset of clinical symptoms are indicative of an AMI. ${ }^{11}$ However, such changes in cTn concentrations might also occur in the absence of clinical symptoms. ${ }^{12,} 13$ To date, little is known about the biological variation in cTn concentrations, although some studies have taken serial measurements to investigate the cTn serum concentrations over longer periods of time. ${ }^{12-16}$

The advent of new, more sensitive cTn assays could improve the usefulness of both single and serial cTn measurements. To date, most commercial cTn assays lack a sufficient analytical performance to accurately detect cTn concentrations in healthy subjects, either because the limit of detection (LOD) of the assay is higher than the reference concentrations or because the assay imprecision, expressed as the 
coefficient of variation $(\mathrm{CV})$ is higher than $10 \%$ at the $99^{\text {th }}$ percentile of the healthy subjects. ${ }^{17-19}$ Assays with sufficient sensitivity to determine the reference concentrations will improve the detection of "abnormal" cTn concentrations in ESRD and other patient populations. More precise assays will also be able to detect temporal changes in cTn concentrations which could not be detected to date. Such increasingly confident measurements will not only identify patients with abnormal cTn concentrations and variations, but could also shed light on the discrepancy between cardiac troponin $\mathrm{T}(\mathrm{cTnT})$ and cardiac troponin I (cTnI). Until recently the number of ESRD patients showing increased cTnT concentrations was about three times as high as for cTnI (53\% vs 17\%). ${ }^{5}$ With the advent of new, more sensitive cTnI assays, the difference decreases, but the number of patients with cTn concentrations above the $10 \% \mathrm{CV}$ limit of the assay is still larger for CTnT (59\%) than for $\operatorname{TnI}(32 \%){ }^{20}$

In this study we investigate the performance of two recently developed cTn assays: the pre-commercial high-sensitive cTnT assay (hs-cTnT) (Roche Diagnostics, Mannheim, Germany) and the Architect i2000SR cTnI assay (cTnI) (Abbott Diagnostics, Wiesbaden, Germany) in measuring cTn concentrations in a population of haemodialysis patients. For comparison, cTnT was also measured using the current $4^{\text {th }}$ generation cTnT immunoassay (Roche Diagnostics, Mannheim, Germany). In addition, we assessed the intra-individual variation in the cTn concentrations during a 6-month follow-up.

\section{Materials and methods}

\section{Reference population}

Baseline cardiac biomarker concentrations were determined in a reference population of 501 apparently healthy persons who participated in a health check program at the University Hospital Maastricht, the Netherlands. In accordance with the recent NACB practice guidelines in acute coronary syndromes (ACS), the $99^{\text {th }}$ percentile upper reference limits (URL) were determined in this population. ${ }^{9}$ To exclude participants with potential cardiac syndromes, outliers were excluded when cTn (I or T), N-Terminal Pro-Brain-type Natriuretic Peptide (NT-proBNP) or creatine kinase $\mathrm{MB}$ isoenzyme (CK-MB) concentrations exceeded the mean 
concentration by more than 3 times the standard deviation. The cut-off concentrations for CK-MB and NT-proBNP were defined gender-specifically. Cutoff concentrations for CK-MB were $10 \mu \mathrm{g} / \mathrm{L}$ for the males and $7.9 \mu \mathrm{g} / \mathrm{L}$ for the females. The NT-proBNP cut-off concentration was $41 \mathrm{pmol} / \mathrm{L}(=347 \mathrm{pg} / \mathrm{mL})$ for both males and females. In effect, 22 subjects were excluded because of outlying cardiac biomarker concentrations, 10 subjects on the basis of CK-MB, 8 subjects because of NT-proBNP and 4 subjects because of cTn (I or T). Additionally, 2 subjects were excluded because they were $<18$ years old, leaving a total of 477 subjects.

\section{Patient population}

A cohort of 44 chronic haemodialysis patients from the Department of Internal Medicine at the University Hospital Maastricht was selected to participate in this 6month longitudinal study. The study protocol was approved by the medical ethical review committee of the University Hospital Maastricht (Medical Ethical Committee AZM/UM). All patients provided written informed consent. Blood samples were collected pre-dialysis at the start of the study and subsequently every two months for a period of 6 months. During the follow-up period 12 patients were hospitalized. The reasons for hospitalization were very diverse, briefly: pneumonia; stoma operation; removal of kidney transplant; kidney transplant; malaise after chemotherapy; rectal blood loss/diarrhea; nausea, vomiting; hip replacement; kidney transplant followed by Ileus; hypoglycaemia/collaps; dizziness/fall; subdural hematoma. Since one of our aims was to study the occurrence of cTn variations in a stable (e.g. with no acute worsening in the patient's condition) population of ESRD patients, hospitalized patients were excluded from our analysis. Collected blood samples were allowed to clot and then centrifuged: obtained serum samples were stored at $-80{ }^{\circ} \mathrm{C}$ until analysis. Four patients failed to have blood taken at one occasion. Clinical data were collected from the medical records in our hospital. Patients could be divided into two groups on the basis of a history of cardio vascular disease (CVD). CVD was considered present when patients had a history of myocardial infarction, had required coronary intervention (e.g. percutaneous transluminal coronary 
angioplasty (PTCA), coronary Artery Bypass Grafting (CABG)) or suffered from congestive cardiac failure.

\section{Laboratory Methods}

CTnT was measured on the Elecsys 2010 (Roche Diagnostics, Mannheim, Germany) using the $4^{\text {th }}$ generation $c \operatorname{TnT}$ immunoassay with a limit of detection (LOD) of $0.01 \mu \mathrm{g} / \mathrm{L}$ and a $10 \% \mathrm{CV}$ of $0.03 \mu \mathrm{g} / \mathrm{L}$ (according to package insert). CTnT was additionally measured using the pre-commercial high-sensitive cTnT (hscTnT) assay on the Elecsys 2010. According to the manufacturers data (J. Jarausch, personal communication) the $10 \% \mathrm{CV}$ was estimated at $0.012 \mu \mathrm{g} / \mathrm{L}$. CTnI was measured on the Architect i2000SR (Abbott Diagnostics, Wiesbaden, Germany). According to the manufacturer's data, the LOD of the assay is $0.009 \mu \mathrm{g} / \mathrm{L}$ and the $10 \% \mathrm{CV}$ concentration is $0.032 \mu \mathrm{g} / \mathrm{L}$. Precision profiles for the hs-cTnT and the cTnI assay were determined in our laboratory by repeated $(n=20)$ measurements in 7 pooled serum samples (cTnI concentrations ranging from 0.017 to $0.088 \mu \mathrm{g} / \mathrm{L}$ and cTnT concentrations ranging from $0.002 \mu \mathrm{g} / \mathrm{L}$ to $0.019 \mu \mathrm{g} / \mathrm{L}$ ) as described previously. ${ }^{21}$ The resulting $10 \% \mathrm{CV}$ concentrations for the hs-cTnT and cTnI assays were found at $0.009 \mu \mathrm{g} / \mathrm{L}$ and $0.032 \mu \mathrm{g} / \mathrm{L}$ respectively. The LODs for the hs-cTnT and cTnI assays were calculated in our laboratory according to the Clinical and Laboratory Standards Institute (CLSI) EP17 guidelines. According to these guidelines the $\mathrm{LOD}=($ meanblank $+1,645 *$ SDblank $)+(1,645 *$ SDlow concentration sample $)$. The LOB, determined in cTn negative serum (supplied to us by Abbott Diagnostics) by replicate $(n=10)$ measurements revealed a LOB of $0.006 \mu \mathrm{g} / \mathrm{L}$ for the cTnI assay (mean cTnI $=0.001 \mu \mathrm{g} / \mathrm{L} ; \mathrm{SD}=0.003 \mu \mathrm{g} / \mathrm{L}$ ) and a LOB of $<0.001 \mu \mathrm{g} / \mathrm{L}$ for the hscTnT assay (mean and SD $<0.001 \mu \mathrm{g} / \mathrm{L})$. Replicate measurements $(n=20)$ in a serum sample containing a mean cTnI concentration of $0.017 \mu \mathrm{g} / \mathrm{L}$ showed a SD of 0.003 $\mu \mathrm{g} / \mathrm{L}$ for the Architect cTnI assay. Replicate measurements $(n=20)$ with the hs-cTnT assay in a serum sample containing a mean cTnT concentration of $0.002 \mu \mathrm{g} / \mathrm{L}$ showed a SD of $0.00072 \mu \mathrm{g} / \mathrm{L}$. The resulting LOD is thus established at $0.011 \mu \mathrm{g} / \mathrm{L}$ for the cTnI assay and at $0.001 \mu \mathrm{g} / \mathrm{L}$ for the hs-cTnT assay. In subsequent calculations cTnI concentrations measured below the analytical LOD were set equal to the LOD of the assay. 


\section{Statistical analysis}

Data analyses were performed using Statistical Package for Social Sciences (SPSS), Version 15.0 for Windows (SPSS Inc., Chicago, IL, USA). Continuous variables are described as median and interquartile range (IQR) or as mean and standard deviation (SD). Categorical variables are described as absolute numbers and as percentages. Biovariability data was analyzed by calculating the intra-individual coefficient of variation $(\mathrm{CVi})$ and the range (min-max) of cTn concentrations measured during the follow-up. The CVi was calculated by subtracting the analytical variation (CVa) from the total variation (CVtot), such that $\mathrm{CVtot}^{2}=\mathrm{CVi}^{2}$ $+\mathrm{CVa}^{2}$. The analytical variation is estimated by extrapolating the CVa from the precision profiles for the hs-cTnT and cTnI assays (precision profiles shown previously ${ }^{21}$ ). For the 4 th generation cTnT assay the CVa is extrapolated from the precision profile in the package insert for this assay. The maximum percent change during the 6 month period for each of the patients is calculated as the ((maximum concentration measured during the 6 month period minus the minimum concentration) / minimum concentration) ${ }^{*} 100 \%$. Differences in cTn concentrations and variations (ranges) between patients with and without cardiac disease were compared using the Mann-Whitney-U test. The level of statistical significance was established at $\mathrm{p}<0.05$.

\section{Results}

\section{The reference population}

Our reference population consisted of 264 male and 213 female subjects with an average (SD) age of $51 \mathrm{y}$ (10.5). Mean cTnT concentrations according to the hs-cTnT assay were $0.004 \mu \mathrm{g} / \mathrm{L}(\mathrm{SD}=0.003 \mu \mathrm{g} / \mathrm{L})$ and the mean cTnI concentration was $0.001 \mu \mathrm{g} / \mathrm{L}(\mathrm{SD}=0.003 \mu \mathrm{g} / \mathrm{L})$. The $99^{\text {th }}$ percentile URLs for the $\mathrm{cTn}$ assays under investigation were $0.016 \mu \mathrm{g} / \mathrm{L}$ for the hs-cTnT assay and $0.013 \mu \mathrm{g} / \mathrm{L}$ for the cTnI assay. The $9^{\text {th }}$ percentile URL for the current $4^{\text {th }}$ generation $c$ TnT assay was set at $0.01 \mu \mathrm{g} / \mathrm{L}$ because all of the measurements lay below the LOD $(<0.01 \mu \mathrm{g} / \mathrm{L})$.

Figure 1 visualizes the cTn concentrations measured by the hs-cTnT (figure 1A) and the cTnI assays (figure 1B). According to the hs-cTnT assay $92 \%$ of the cTnT concentrations lie above the LOD and follow an almost Gaussian distribution. In 
contrast, only $2 \%$ of the concentrations measured by the cTnI assay lie above the LOD. Furthermore, the $99^{\text {th }}$ percentile URL calculated for the hs-cTnT assay lies above the concentration at which the $\mathrm{CV}$ is $<10 \%$. Conversely, for the $\mathrm{cTnI}$ assay the $99^{\text {th }}$ percentile URL lies below the concentration at which the $\mathrm{CV}$ was $<10 \%$.
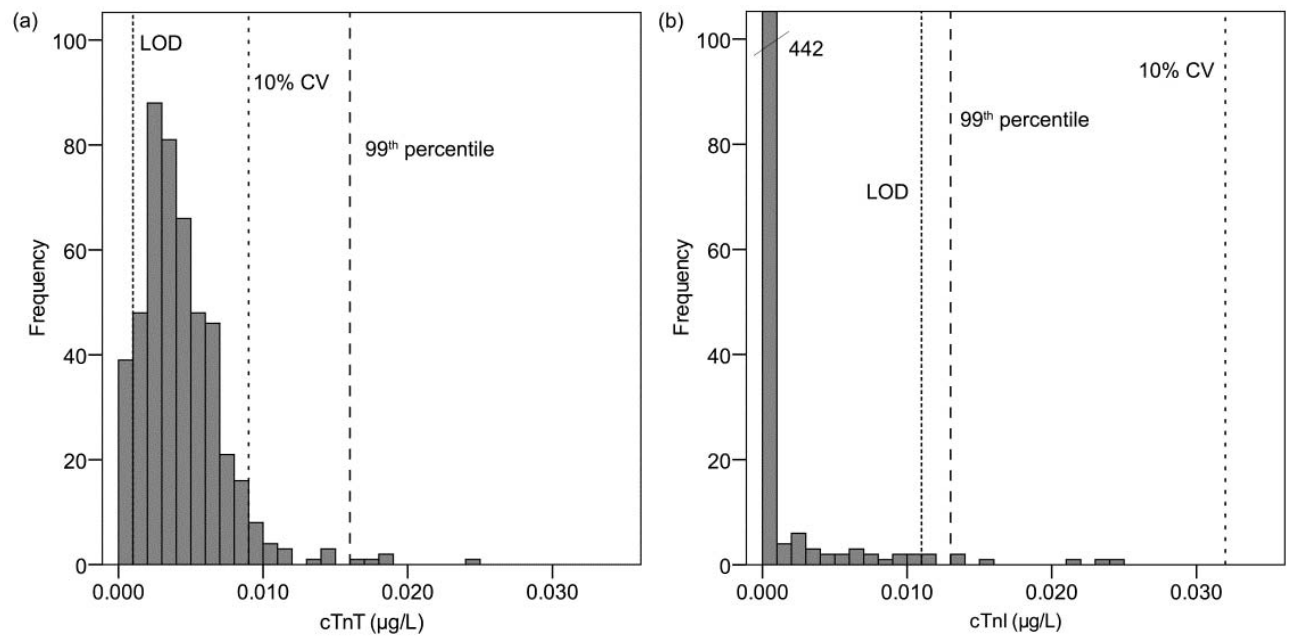

Figure 1. CTn concentrations in the reference population as measured with (a) hs-cTnT and (b) the CTnl assay.

\section{Baseline measurements in the patient population}

Table 1 shows the characteristics of the 32 ESRD patients enrolled in our study. Measurements at baseline revealed median cTn concentrations (IQR) as detected by the cTnT, hs-cTnT and cTnI assays of $0.02 \mu \mathrm{g} / \mathrm{L}(<0.01-0.05), 0.053 \mu \mathrm{g} / \mathrm{L}(0.032-$ $0.076)$ and $0.014 \mu \mathrm{g} / \mathrm{L}(0.011-0.027)$ respectively. 


\section{Chapter 2}

Table 1. Baseline characteristics of the ESRD patient population.

\begin{tabular}{ll}
\hline Characteristic & \\
\hline Men & 21 \\
Women & 11 \\
Age (min-max) in y & $66(35-91)$ \\
Time on dialysis (min-max) in months & $33(1-102)$ \\
Hypertension & $28(88 \%)$ \\
Diabetes & $12(38 \%)$ \\
History of ischaemic heart disease & $10(31 \%)$ \\
History of cardiac failure & $9(28 \%)$ \\
Patient with (history of) cardiac disease & $17(53 \%)$ \\
\hline
\end{tabular}

Table 2 shows the number of patients having cTn concentrations above the different analytical cut-off values. At baseline 12 (38\%), 30 (94\%) and 6 (19\%) patients showed cTn concentrations above the designated AMI cut-off values according to the cTnT, the hs-cTnT and the cTnI assays, respectively.

Table 2. Number of patients having above cut-off cardiac troponin concentrations at baseline and at least once during the 6-month follow-up.

\begin{tabular}{llllll}
\hline Cardiac troponin assay & LOD & $10 \%$ CV & 99th percentile & AMI cut-off* \\
\hline \multirow{2}{*}{ cTnT } & Cut-off $(\mu \mathrm{g} / \mathrm{L})$ & $<0.01$ & 0.03 & $<0.01$ & 0.03 \\
& Baseline & $20(63 \%)$ & $12(38 \%)$ & $20(63 \%)$ & $12(38 \%)$ \\
& Follow-up & $31(97 \%)$ & $26(81 \%)$ & $31(97 \%)$ & $26(81 \%)$ \\
\multirow{2}{*}{ hs-cTnT } & Cut-off $(\mu \mathrm{g} / \mathrm{L})$ & 0.001 & 0.009 & 0.016 & 0.016 \\
& Baseline & $32(100 \%)$ & $32(100 \%)$ & $30(94 \%)$ & $30(94 \%)$ \\
& Follow-up & $32(100 \%)$ & $32(100 \%)$ & $32(100 \%)$ & $32(100 \%)$ \\
\multirow{2}{*}{ cTnI } & Cut-off $(\mu \mathrm{g} / \mathrm{L})$ & 0.011 & 0.032 & 0.013 & 0.032 \\
& Baseline & $17(53 \%)$ & $6(19 \%)$ & $16(50 \%)$ & $6(19 \%)$ \\
& Follow-up & $23(72 \%)$ & $9(28 \%)$ & $22(69 \%)$ & $9(28 \%)$ \\
\hline
\end{tabular}

* According to recent NACB guidelines the $99^{\text {th }}$ percentile is the recommended cut-off concentration in AMI. However, the assay imprecision $(\% \mathrm{CV})$ should be $\leq 10 \%$ at the $99^{\text {th }}$ percentile ${ }^{9}$, otherwise the $10 \% \mathrm{CV}$ concentration is used. 


\section{Serial measurements in the patient population}

Figure 2 shows the range of concentrations measured during the follow-up in each patient for each of the biomarkers under investigation for both patients with $(\mathrm{n}=17)$ and without $(\mathrm{n}=15)$ a history of CVD. This section discusses the range of cTn concentrations measured in all patients; in the next section we investigate the differences between patients with and without CVD.

During the 6-month follow-up we found a median (IQR) cTn concentration of 0.037 $\mu \mathrm{g} / \mathrm{L}(0.017-0.074), 0.055 \mu \mathrm{g} / \mathrm{L}(0.033-0.079)$ and $0.014 \mu \mathrm{g} / \mathrm{L}(<0.011-0.028)$ for the cTnT, hs-cTnT and cTnI assays respectively. As can be seen in figure 2, the patients experienced large changes in cTn concentrations during the follow-up and the range of concentrations measured within each patient had a median (IQR) magnitude of $0.03 \mu \mathrm{g} / \mathrm{L}(0.02-0.06), 0.017 \mu \mathrm{g} / \mathrm{L}(0.011-0.029)$ and $0.011 \mu \mathrm{g} / \mathrm{L}(0-$ 0.017) according to the the cTnT, hs-cTnT and cTnI assays, respectively. This corresponded to a median within patient percent change of $150 \%$ (72-287), 44\% (27-69) and 54\% (0 - 114) for the cTnT, hs-cTnT and cTnI assays respectively. The total coefficient of variation (CVtot) was $40 \%, 16 \%$ and $20 \%$ for the aforementioned assays. The CVa belonging to the median concentrations measured during the follow-up (as estimated from the precision profiles) is 7\% according to the cTnT assay (median $\mathrm{cTnT}=0.037 \mu \mathrm{g} / \mathrm{L}$ ), $5 \%$ according to the hs-cTnT assay (median $\mathrm{cTnT}=0.055 \mu \mathrm{g} / \mathrm{L}$ ) and $15 \%$ for the $\mathrm{cTnI}$ assay (median $\mathrm{CTnI}=0.014 \mu \mathrm{g} / \mathrm{L}$ ). The CVi is thus $39 \%, 15 \%$ and $13 \%$ for the $\mathrm{cTnT}$, hs-cTnT and cTnI assays, respectively.

Considering the magnitude of the variation it is not surprising that the serial measurements identified additional patients that had cTn concentrations above the previously mentioned cut-off concentrations (at least once) during the 6-month period. During the follow-up we found that $26(81 \%), 32(100 \%)$ and $9(28 \%)$ patients had cTn concentrations above the AMI cut-off level according to the cTnT, hs-cTnT and cTnI assays, respectively. Table 2 shows the number of patients exceeding the pre-defined cut-off concentrations during the 6 month period. 


\section{Chapter 2}
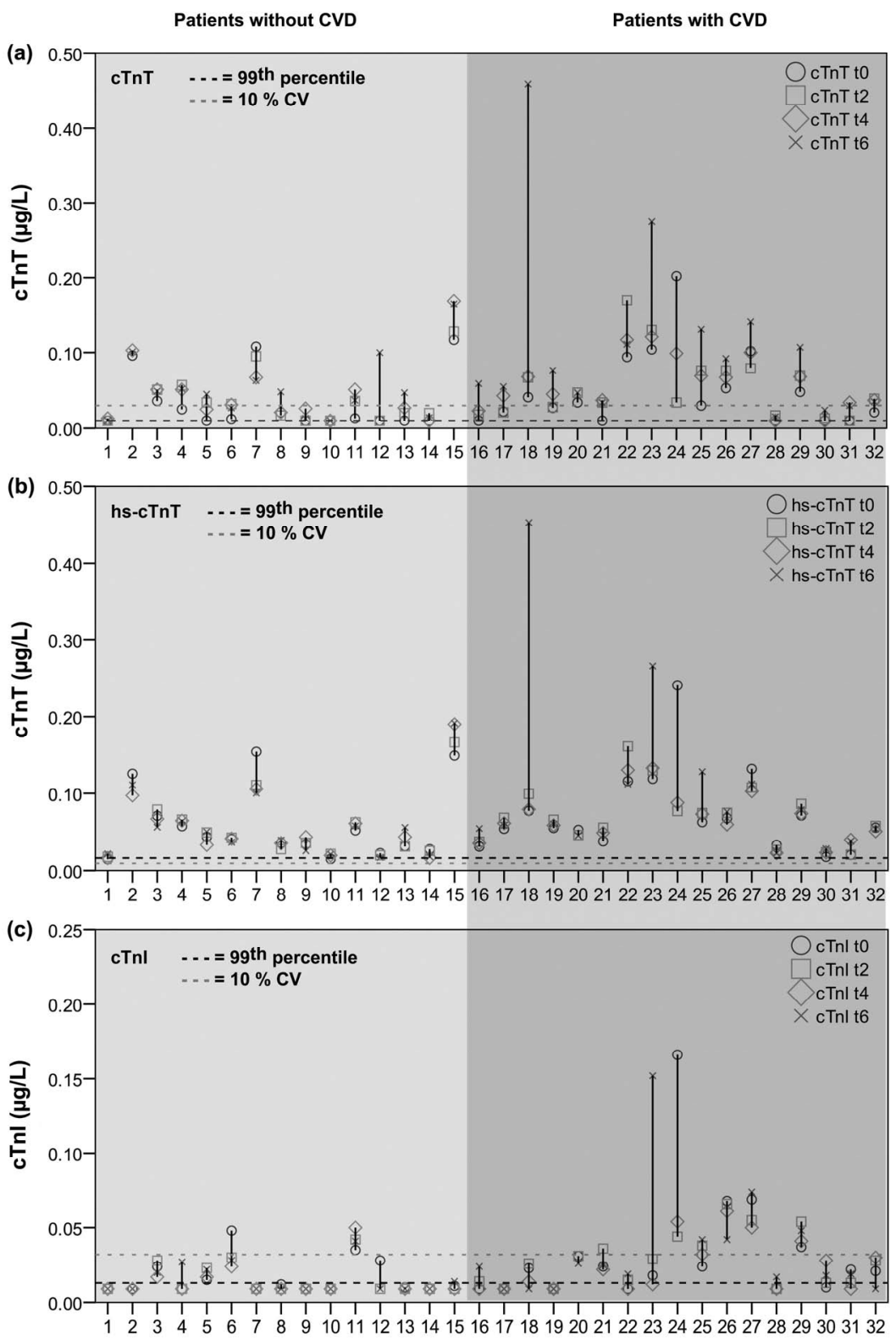

Figure 2. Range of concentrations measured in each patient during the study. (a) cTnT concentrations according to the cTnT assay (b) cTnT concentrations according to the hs-cTnT assay (c) cTnI concentrations. 


\section{Patients with and without a history of cardiovascular disease}

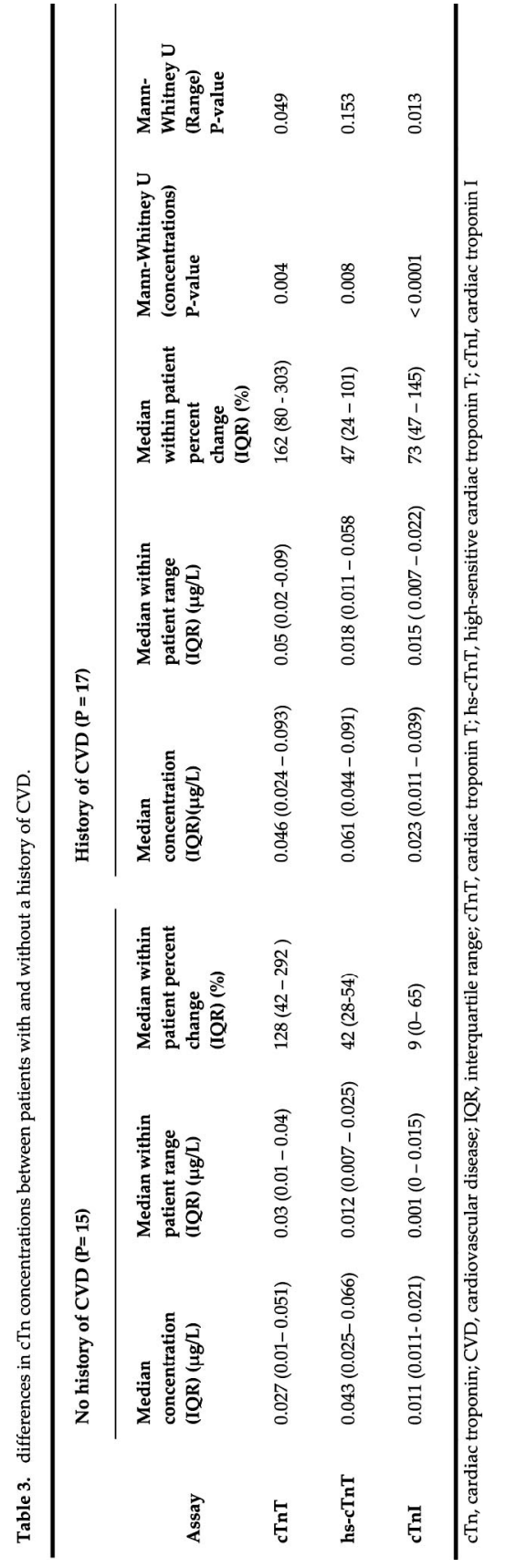

As could already be seen in figure 2, large differences exist between the cTn concentrations and variations in patients with and without a history of CVD. Table 3 quantifies the differences in the cTn concentrations measured during the follow-up. The three assays showed significantly higher concentrations of cTn in the patients who suffered from CVD. In addition, as might be expected, the relative number of patients having elevated concentrations of cTn is higher in the group with CVD. This difference is particularly large for the cTnI assay where only 2 out of 15 patients without CVD have cTnI concentrations above the AMI cut-off concentration, compared to 7 out of 17 in the patients with CVD. Moreover, the variations in the cTn concentrations, as assessed by the ranges of concentrations measured during the follow up, are larger in the CVD patients. Note however, that, as can be seen in table 4 , the variations in cTn concentrations are, in part, the result of analytical rather than biological variations. When the results are assessed for the individual patients, we find a large degree of heterogeneity in the agreement between cTnT and cTnI elevations. In some cases, as with 
patients 23 and 24 one can identify severely elevated concentrations of both cTnT and cTnI, which both seem to increase/decrease at the same time. On the other hand, there are patients, such as 7, 15 and 18 which show very strong elevations (i.e. $>0.1 \mu \mathrm{g} / \mathrm{L}$ ) in cTnT (according to both cTnT assays), yet virtually no elevations in cTnI concentrations. In general, patients with elevated concentrations of cTnI also have elevated concentrations of cTnT, but patients with elevated concentrations of cTnT do not always have elevated concentrations of cTnI.

Table 4. Intra individual coefficients of variation in patients with and without a history of CVD.

\begin{tabular}{|c|c|c|c|c|c|c|}
\hline \multirow[b]{2}{*}{ Assay } & \multicolumn{3}{|c|}{ No history of CVD $(\mathrm{P}=15)$} & \multicolumn{3}{|c|}{ History of CVD $(\mathrm{P}=17)$} \\
\hline & CVtot & $\mathrm{CVa}$ & Cvi & CVtot & $\mathrm{CVa}$ & $\mathrm{CVi}$ \\
\hline cTnT & 35 & 10 & 34 & 47 & 6 & 47 \\
\hline hs-cTnT & 14 & 5 & 13 & 17 & 5 & 16 \\
\hline cTnI & n.a.* & $>15 \% *$ & n.a.* & 24 & 2 & 21 \\
\hline
\end{tabular}

* The coefficients of variations for the patient without CVD could not be determined accurately for the cTnI assay.

\section{Discussion}

This study describes, for the first time, the performance of a pre-commercial hscTnT assay in measuring cardiac troponin elevations and variations in a population of ESRD patients during a 6-month follow-up. In addition, we compared its performance to the current $4^{\text {th }}$ generation cTnT and the Architect $\mathrm{cTnI}$ assays. In the past, several studies have shown the occurrence of elevated cTn concentrations in ESRD patients without apparent cardiac damage and clinical symptoms. ${ }^{22-26}$ These elevated concentrations of cTn are of cardiac origin ${ }^{27}$ and were shown to be highly predictive for a cardiovascular event. ${ }^{3,4,24} \mathrm{~A}$ meta-analysis combining results from 28 studies (3931 patients) showed that cTnT concentrations above $0.1 \mu \mathrm{g} / \mathrm{L}$ were associated with an increase in all-cause mortality (relative risk: 2.64). ${ }^{3}$ Other studies have shown an increased mortality in ESRD patients with cTnT concentrations above $0.026 \mu \mathrm{g} / \mathrm{L}^{24}$ and $0.01 \mu \mathrm{g} / \mathrm{l}^{4}$ Due to the lack of standardization in the available assays, the prognostic value of cTnI is less conclusive and cut-off concentrations cannot be compared between assays. 
Nonetheless, elevated concentrations of cTnI have also been shown to be associated with an increased mortality in ESRD patients..$^{4,22}$

In agreement with previous studies, ${ }^{22-26}$ we found that 12 (38\%) of our patients had elevated concentrations of cTnT according to the current cTnT assay and $6(19 \%)$ had elevated concentrations of cTnI according to the Archtitect cTnI assay. Using the recently developed pre-commercial hs-cTnT assay we find that the occurrence of elevated concentrations of cTnT is far greater than previously described and at baseline 30 (94\%) of the ESRD patients showed elevated concentrations of cTnT.

By following the cTn concentrations at regular points in time, we have identified an additional number of patients with elevated cTn concentrations. During the follow-up $26(81 \%), 32(100 \%)$ and $9(28 \%)$ of the patients showed cTn concentrations above the AMI cut-off concentrations according to the cTnT, hscTnT and cTnI assays respectively. As elevated concentrations of cTn are highly prognostic of adverse events in ESRD patients, the use of serial measurements has thus identified additional patients at risk for such events. The fact that we find cTn concentrations to be higher in patients with a history of cardiovascular disease seems to be in line with this.

We should note however, that due to differences in the precision with which the 99 $9^{\text {th }}$ percentile can be determined, the AMI cut-offs for the assays are set at different concentrations. For the cTnT and CTnI assays, the $10 \% \mathrm{CV}$ cut-off concentrations are used, whereas for the hs-cTnT assay, the 99th percentile URL is used. When we assess the occurrence of cTn elevations above the $99^{\text {th }}$ percentile URL, we find that the difference between the assays is much smaller and 31 (97\%) of the patients have cTnT elevations and $22(69 \%)$ have cTnI elevations versus 32 $(100 \%)$ for the hs-cTnT assay. Considering the fact that the $4^{\text {th }}$ generation cTnT and the Architect cTnI assays were not able to detect the $99^{\text {th }}$ percentile with sufficient precision $(<10 \mathrm{CV} \%)$ these findings however, should be interpreted with caution. Nonetheless, they suggest that more sensitive CTnI measurements could reveal that the occurrence of cTnI elevations in ESRD patients is more frequent than is presently thought. This idea is supported by recent findings with sensitive $\mathrm{CTnI}$ assays in $\mathrm{ESRD}^{20}$ and chronic kidney disease patients, ${ }^{28}$ which find more cTnI elevations than previously described. 
In general, there seems to be a great degree of heterogeneity between the patients in the amount of variation in their cTn concentrations. For instance, according to the new hs-cTnT assay, 8 (25\%) of the patients experienced changes in cTnT $>0.03$ $\mu \mathrm{g} / \mathrm{L}$, whereas another $8(25 \%)$ of the patients had variations $<0.01 \mu \mathrm{g} / \mathrm{L}$ during the 6-month follow-up. Thus, as can also been seen in figure 2, the patient population consisted of a group of patients with relatively stable cTn concentrations and a group with a high degree of variations in their cTn concentrations. Further research, in a larger population is needed to identify if the patients with the higher degree of variation are at greater risk for adverse events.

According to recent NACB guidelines only patients with chronically elevated concentrations of cTn, with changes in cTn (>20\%) 6-9 hours after the onset of clinical symptoms are suffering from an AMI. ${ }^{11}$ Therefore, none of our patients would have been classified as having an AMI. Nonetheless, as increases in cTn represent further (subclinical) myocardial damage and an increased likelihood for cardiac events, they should not be ignored. It would therefore be wise to perform a detailed cardiac evaluation in patients showing large variations in cTn concentrations, even if these variations are not accompanied by clinical symptoms. The increases in cTn, as seen in many of our patients, would, if not for the longitudinal study, have been detected. Assessing cTn concentrations at regular points in time would therefore appear as a sensible tool to increase clinical vigilance for the presence of myocardial damage and as a means for possible intervention. This is in agreement with previous studies which provided evidence for the increased ability of serial versus single measurements to identify patients at risk for an event. ${ }^{12-16}$

In the setting of heart failure, previously undetectable concentrations of cTnT were shown to have important prognostic value.29 The use of highly sensitive cTn assays, like the hs-cTnT assay, will enable a better differentiation between cTn concentrations in healthy and diseased patients and could improve risk stratification. Regrettably, our study was limited by a small sample size and the absence of outcomes. Therefore, additional research is needed to show if this prognostic value exists in the setting of ESRD and how patients can further benefit from serial measurements with highly sensitive cTn assays. 


\section{References}

1. National Institutes of Health; National Institute of Diabetes and Digestive and Kidney Diseases; Bethesda M. U.S. Renal Data System, USRDS 2007 Annual Data Report: Atlas of Chronic Kidney Disease and End-Stage Renal Disease in the United States. 2007:138-154

2. U.S. Renal data system, usrds 2007 annual data report: Atlas of chronic kidney disease and endstage renal disease in the united states, national institutes of health, national institute of diabetes and digestive and kidney diseases, bethesda, md, 2007. 2007:192-208

3. Khan NA, Hemmelgarn BR, Tonelli M, Thompson CR, Levin A. Prognostic value of troponin $t$ and i among asymptomatic patients with end-stage renal disease: A meta-analysis. Circulation. 2005;112:3088-3096

4. Apple FS, Murakami MM, Pearce LA, Herzog CA. Predictive value of cardiac troponin i and $t$ for subsequent death in end-stage renal disease. Circulation. 2002;106:2941-2945.

5. Kanderian AS, Francis GS. Cardiac troponins and chronic kidney disease. Kidney Int. 2006;69:11121114

6. Lamb EJ, Webb MC, Abbas NA. The significance of serum troponin $t$ in patients with kidney disease: A review of the literature. Ann Clin Biochem. 2004;41:1-9

7. Diris JH, Hackeng CM, Kooman JP, Pinto YM, Hermens WT, Van Dieijen-Visser MP. Impaired renal clearance explains elevated troponin $t$ fragments in hemodialysis patients. Circulation. 2004;109:23-25

8. Wiessner R, Hannemann-Pohl K, Ziebig R, Grubitzsch H, Hocher B, Vargas-Hein O, Lun A, Schimke I, Liefeldt L. Impact of kidney function on plasma troponin concentrations after coronary artery bypass grafting. Nephrol Dial Transplant. 2008; 23:231-238

9. Apple FS, Jesse RL, Newby LK, Wu AH, Christenson RH, Cannon CP, Francis G, Morrow DA, Ravkilde J, Storrow AB, Tang W, Jaffe AS, Mair J, Ordonez-Llanos J, Pagani F, Panteghini M, Tate J. National academy of clinical biochemistry and ifcc committee for standardization of markers of cardiac damage laboratory medicine practice guidelines: Analytical issues for biochemical markers of acute coronary syndromes. Clin Chem. 2007;53:547-551

10. Thygesen K, Alpert JS, White HD, Jaffe AS, Apple FS, Galvani M, Katus HA, Newby LK, Ravkilde J, Chaitman B, Clemmensen PM, Dellborg M, Hod H, Porela P, Underwood R, Bax JJ, Beller GA, Bonow R, Van Der Wall EE, Bassand JP, Wijns W, Ferguson TB, Steg PG, Uretsky BF, Williams DO, Armstrong PW, Antman EM, Fox KA, Hamm CW, Ohman EM, Simoons ML, Poole-Wilson PA, Gurfinkel EP, Lopez-Sendon JL, Pais P, Mendis S, Zhu JR, Wallentin LC, Fernandez-Aviles F, Fox KM, Parkhomenko AN, Priori SG, Tendera M, Voipio-Pulkki LM, Vahanian A, Camm AJ, De Caterina R, Dean V, Dickstein K, Filippatos G, Funck-Brentano C, Hellemans I, Kristensen SD, McGregor K, Sechtem U, Silber S, Tendera M, Widimsky P, Zamorano JL, Morais J, Brener S, Harrington R, Morrow D, Sechtem U, Lim M, Martinez-Rios MA, Steinhubl S, Levine GN, Gibler WB, Goff D, Tubaro M, Dudek D, Al-Attar N. Universal definition of myocardial infarction: Kristian thygesen, joseph s. Alpert and harvey d. White on behalf of the joint esc/accf/aha/whf task force for the redefinition of myocardial infarction. Eur Heart J. 2007;28:2525-2538

11. Wu AH, Jaffe AS, Apple FS, Jesse RL, Francis GL, Morrow DA, Newby LK, Ravkilde J, Tang WH, Christenson RH, Cannon CP. National academy of clinical biochemistry laboratory medicine practice guidelines: Use of cardiac troponin and b-type natriuretic peptide or n-terminal prob-type natriuretic peptide for etiologies other than acute coronary syndromes and heart failure. Clin Chem. 2007;53:2086-2096

12. Roberts MA, Fernando D, Macmillan N, Proimos G, Bach LA, Power DA, Ratnaike S, Ierino FL. Single and serial measurements of cardiac troponin $\mathrm{i}$ in asymptomatic patients on chronic hemodialysis. Clin Nephrol. 2004;61:40-46 


\section{Chapter 2}

13. Miller WL, Hartman KA, Burritt MF, Grill DE, Rodeheffer RJ, Burnett JC, Jr., Jaffe AS. Serial biomarker measurements in ambulatory patients with chronic heart failure: The importance of change over time. Circulation. 2007;116:249-257

14. Ooi DS, Zimmerman D, Graham J, Wells GA. Cardiac troponin t predicts long-term outcomes in hemodialysis patients. Clin Chem. 2001;47:412-417.

15. Wayand D, Baum H, Schatzle G, Scharf J, Neumeier D. Cardiac troponin $t$ and $i$ in end-stage renal failure. Clin Chem. 2000;46:1345-1350.

16. Han JH, Lindsell CJ, Ryan RJ, Gibler WB. Changes in cardiac troponin $t$ measurements are associated with adverse cardiac events in patients with chronic kidney disease. Am J Emerg Med. 2005;23:468-473

17. Panteghini M, Pagani F, Yeo KT, Apple FS, Christenson RH, Dati F, Mair J, Ravkilde J, Wu AH. Evaluation of imprecision for cardiac troponin assays at low-range concentrations. Clin Chem. 2004;50:327-332

18. Giannitsis E, Katus HA. Comparison of cardiac troponin $t$ and troponin $i$ assays--implications of analytical and biochemical differences on clinical performance. Clin Lab. 2004;50:521-528

19. Panteghini M. The new definition of myocardial infarction and the impact of troponin determination on clinical practice. Int J Cardiol. 2006;106:298-306

20. Hickman PE, Koerbin G, Southcott E, Tate J, Dimeski G, Carter A, McGill D, Talaulikar G, Potter JM. Newer cardiac troponin i assays have similar performance to troponin $t$ in patients with endstage renal disease. Ann Clin Biochem. 2007;44:285-289

21. Mingels A, Jacobs L, Michielsen E, Swaanenburg J, Wodzig W, van Dieijen-Visser M. Reference population and marathon runner sera assessed by highly sensitive cardiac troponin $t$ and commercial cardiac troponin $t$ and $i$ assays. Clin Chem. 2009;46:283-290

22. Apple FS, Murakami MM, Pearce LA, Herzog CA. Multi-biomarker risk stratification of n-terminal pro-b-type natriuretic peptide, high-sensitivity c-reactive protein, and cardiac troponin $\mathrm{t}$ and $\mathrm{i}$ in end-stage renal disease for all-cause death. Clin Chem. 2004;50:2233-2235

23. Havekes B, van Manen JG, Krediet RT, Boeschoten EW, Vandenbroucke JP, Dekker FW. Serum troponin $\mathrm{t}$ concentration as a predictor of mortality in hemodialysis and peritoneal dialysis patients. Am J Kidney Dis. 2006;47:823-829

24. Sommerer C, Beimler J, Schwenger V, Heckele N, Katus HA, Giannitsis E, Zeier M. Cardiac biomarkers and survival in haemodialysis patients. Eur J Clin Invest. 2007;37:350-356

25. Aviles RJ, Askari AT, Lindahl B, Wallentin L, Jia G, Ohman EM, Mahaffey KW, Newby LK, Califf RM, Simoons ML, Topol EJ, Berger P, Lauer MS. Troponin t levels in patients with acute coronary syndromes, with or without renal dysfunction. N Engl J Med. 2002;346:2047-2052.

26. deFilippi C, Wasserman S, Rosanio S, Tiblier E, Sperger H, Tocchi M, Christenson R, Uretsky B, Smiley M, Gold J, Muniz H, Badalamenti J, Herzog C, Henrich W. Cardiac troponin t and c-reactive protein for predicting prognosis, coronary atherosclerosis, and cardiomyopathy in patients undergoing long-term hemodialysis. Jama. 2003;290:353-359

27. Fredericks S, Murray JF, Bewick M, Chang R, Collinson PO, Carter ND, Holt DW. Cardiac troponin $\mathrm{t}$ and creatine kinase $\mathrm{mb}$ are not increased in exterior oblique muscle of patients with renal failure. Clin Chem. 2001;47:1023-1030.

28. Lamb EJ, Kenny C, Abbas NA, John RI, Webb MC, Price CP, Vickery S. Cardiac troponin i concentration is commonly increased in nondialysis patients with ckd: Experience with a sensitive assay. Am J Kidney Dis. 2007;49:507-516

29. Latini R, Masson S, Anand IS, Missov E, Carlson M, Vago T, Angelici L, Barlera S, Parrinello G, Maggioni AP, Tognoni G, Cohn JN. Prognostic value of very low plasma concentrations of troponin $\mathrm{t}$ in patients with stable chronic heart failure. Circulation. 2007;116:1242-1249 


\title{
CHAPTER 3
}

\section{Highly sensitive troponin $\mathrm{T}$ versus conventional troponin $\mathrm{T}$ testing for risk stratification in patients} presenting with acute dyspnoea to the emergency department

\begin{abstract}
SUMMARY
Aims: To investigate the value of highly sensitive cardiac troponin $T$ (hs-cTnT) in the risk stratification of patients presenting to the emergency department with dyspnoea.

Methods and results: We prospectively studied 678 consecutive patients presenting to the emergency department with dyspnoea. Patients were subsequently divided into three troponin categories: (i) troponin $T$ not elevated, (ii) troponin $T$ elevated by the hs-cTnT assay only, i.e. $h s-c T n T \geq 0.016 \mu g / L$, and (iii) troponin $T$ elevated by both assays, i.e. $c \operatorname{Tn} T \geq 0.03 \mu \mathrm{g} / \mathrm{L}$ and $h s-c T n T \geq 0.016 \mu \mathrm{g} / \mathrm{L}$. The prognostic value of $h s-c T n T$ for 90 -days and 1-year all-cause mortality was compared with that of conventional cardiac troponin $T$ (cTnT) and N-terminal pro-brain natriuretic peptide (NT-proBNP). The hs-cTnT assay was able to detect troponin $T$ in the majority of patients $(n=648 ; 96 \%)$ whereas only 331 patients $(49 \%)$ had detectable cTnT concentrations. Overall, hs-cTnT was associated with both 90-day and 1-year mortality, independently of traditional clinical risk factors and NT-proBNP. 90-day mortality rate increased over the troponin categories: (i) $2.3 \%$, (ii) $9.5 \%$, and (iii) $26 \%, P<0.001$ ) and patients in the second and third troponin category had a reduced probability of long-term survival (log-rank $P<0.001)$. Moreover, in patients with undetectable $c T n T$ concentrations $(c \operatorname{Tn} T<0.01 \mu \mathrm{g} / \mathrm{L}), h s-c T n T$ was superior to NTproBNP in predicting 90-day mortality.

Conclusion: The hs-cTnT assay improves risk stratification beyond the conventional troponin assay in patients presenting with acute dyspnoea to the emergency department. Particularly, for clinical decision making, the hs-cTnT assay enables identification of lowrisk patients.
\end{abstract}

Part of this work has been published in: Clinical Chemistry 2011 Nov. 18 [Epub ahead of print]

L Jacobs*, S van Wijk*,L Eurlings, $R$ van Kimmenade, $R$ Lemmers, P.Broos,

O Bekers, M Prins, H Crijns, Y Pinto, M Dieijen-Visser, HP Brunner-La Rocca

* Both authors contributed equally 


\section{Introduction}

Cardiac troponins are sensitive markers of cardiac injury and are the preferred biochemical markers for the diagnosis of acute coronary syndrome (ACS).1, 2 However, it has been recognized for some years that cardiac troponin $\mathrm{T}$ ( $\mathrm{cTnT}$ ) may be detected in the absence of ACS, ${ }^{3,4}$ such as in heart failure (HF) patients, ${ }^{5-8}$ patients suffering from end stage renal disease (ESRD), 9,10 and patients with atrial fibrillation..$^{11}$ In these conditions, detectable troponin concentrations were found to be associated with disease severity and worse outcome. Recently, highly sensitive assays with the ability to accurately measure very low troponin concentrations, even in 'healthy' subjects, have been developed. ${ }^{12}$, 13 These highly sensitive cTnT assays (hs-cTnT) enable detection of circulating troponin in the majority of patients with chronic HF and stable coronary artery disease (CAD) and were found to be prognostic in these patients. ${ }^{14,15}$ Although the hs-cTnT assay seems to increase the prognostic power of troponin measurement, only few direct comparisons have been made between the conventional and the highly sensitive assay. ${ }^{16,17}$ Also, it is not yet known whether the prognostic value of hs-cTnT measurements can be extended to acute settings in general, e.g. in patients presenting with acute dyspnoea, since acute dyspnoea is one of the most common and challenging presentations at the emergency department. ${ }^{18,}{ }^{19}$ Despite recent advances in the evaluation of dyspnoeic patients, particularly by using brain natriuretic peptide (BNP) and N-terminal pro-brain natriuretic peptide (NT-proBNP), ${ }^{20-25}$ but also other biomarkers such as, sST2 or galectin-3, ${ }^{24-27}$ assessing individual risk remains difficult. In order to provide best management, it is of importance to accurately stratify risk in these patients. Therefore, we investigated whether hs-cTnT measurements on top of several well-known prognostic factors including NTproBNP may improve both short and long-term risk assessment and whether the prognostic value of the hs-cTnT assay exceeds that of the conventional cTnT assay. 


\section{Methods}

\section{Study population and study design}

Between June 2007 and October 2009, 678 patients aged $>18$ years presenting to the cardiac emergency department of the Maastricht University Medical Centre with dyspnoea as their main complaint were consecutively enrolled in this prospective study. Exclusion criteria were ST-elevated myocardial infarction (STEMI) and dyspnoea resulting from chest trauma. Blood samples were obtained within 30 minutes after arrival at the emergency department. Baseline characteristics including the final cause of dyspnoea were based on the clinical record. Patients were followed for 1 year. Follow-up data were collected via chart review and if necessary, data were obtained from the general practitioner or by enquiry of the municipal register. Primary outcome measure was 90-day all-cause mortality and secondary outcome 1-year all-cause mortality. All investigational procedures involved in this study have been approved by the institutional review board (Medical Ethical Committee MUMC) and comply with the Declaration of Helsinki.

\section{Laboratory analysis}

Measurements of routine laboratory parameters, i.e. NT-proBNP, cTnT, c-reactive protein $(\mathrm{CRP})$, creatinine, and haemoglobin $(\mathrm{Hb})$, were performed immediately after blood collection. Excess of collected serum samples was frozen and stored at $80^{\circ} \mathrm{C}$ until analysis and hs-cTnT concentrations were measured at a later time point ( 1 freeze-thaw cycle). In this study we refer to the conventional, $4^{\text {th }}$ generation troponin $\mathrm{T}$ assay as ' $\mathrm{CTnT}$ ' and we refer to the highly-sensitive, $5^{\text {th }}$ generation troponin $\mathrm{T}$ assay as 'hs-cTnT'. Cardiac troponin $\mathrm{T}$ concentrations were measured with both the cTnT and the hs-cTnT assay, using the Elecsys 2010 analyser (Roche Diagnostics, Mannheim, Germany). The conventional assay has a limit of detection (LOD) of $0.01 \mu \mathrm{g} / \mathrm{L}$, a 99th percentile upper reference limit (URL) of $<0.01 \mu \mathrm{g} / \mathrm{L}$ and a $10 \%$ coefficient of variation $(\mathrm{CV})$ value at $0.03 \mu \mathrm{g} / \mathrm{L}$, as specified by the manufacturer. The highly sensitive assay has a LOD of $0.003 \mu \mathrm{g} / \mathrm{L}$, a $99^{\text {th }}$ percentile URL of $0.016 \mu \mathrm{g} / \mathrm{L}$ and a $10 \% \mathrm{CV}$ at $0.009 \mu \mathrm{g} / \mathrm{L}$, as recently described. ${ }^{28,}{ }^{29} \mathrm{In}$ agreement with recent guidelines, troponin concentrations were considered elevated when the measurements exceeded the $99^{\text {th }}$ percentile URL, with the 
prerequisite that they could be measured with a $\mathrm{CV}<10 \%$. $^{2}$, 30 In keeping with these guidelines, elevated concentrations were defined as $\geq 0.016 \mu \mathrm{g} / \mathrm{L}$ for the hscTnT assay and $\geq 0.03 \mu \mathrm{g} / \mathrm{L}$ for the cTnT assay. NT-proBNP concentrations were measured using the NT-proBNP assay for the Elecsys 2010 and the prospectively defined cut-off of $900 \mathrm{pg} / \mathrm{ml}$ was used. ${ }^{31}$

\section{Statistical analysis}

Data are presented as frequencies, mean \pm SD or median (interquartile range, [IQR]). Patients were divided into three categories based on troponin concentrations: (i) troponin $\mathrm{T}$ not elevated by both assays, (ii) troponin $\mathrm{T}$ elevated by the hs-cTnT assay only, i.e. hs-cTnT $\geq 0.016 \mu \mathrm{g} / \mathrm{L}$, (iii) troponin $\mathrm{T}$ elevated by both assays, i.e. $\mathrm{cTnT} \geq 0.03 \mu \mathrm{g} / \mathrm{L}$ and hs-cTnT $\geq 0.016 \mu \mathrm{g} / \mathrm{L}$. Comparisons between groups were performed using $\chi 2$-tests for categorical data and one-way ANOVA or KruskalWallis $\mathrm{H}$ test for continuous data, as appropriate. Receiver operating characteristic (ROC) analysis was used to assess prognostic accuracy in terms of the area under the curve (AUC) with regard to 90-day mortality. Logistic regression analysis was used to test the association between troponin $\mathrm{T}$ concentrations and 90-day mortality. For long-term outcome, Cox proportional-hazard regression analysis was used. In these models, troponin $\mathrm{T}$ was examined as a categorical variable by troponin categories and as a continuous variable by both assays separately. Adjustments were made for traditional clinical risk factors (age, sex, history of HF, creatinine concentration, dyspnoea severity, systolic blood pressure and left ventricular ejection fraction [LVEF]) with and without NT-proBNP and CRP. We checked for co-linearity and interactions among covariates and found none of significance. Continuous variables not fulfilling linearity assumption were transformed before entry into the models. Calibration of the models was visualized and tested by the Hosmer-Lemeshow statistic. Model accuracy and discrimination were evaluated by (i) c-statistic, a measure of AUC, (ii) integrated discrimination improvement (IDI), and (iii) net reclassification index (NRI), as recently suggested $^{32-34}$ following the method of Pencina et al. ${ }^{34}$ Kaplan-Meier curve plots were estimated and compared by the log-rank test. Tests were two-sided with a level of significance of $\mathrm{P}<0.05$. Calculations were done using SPSS 16.0 (SPSS inc, 
Chicago, Illinois, USA). Comparison of ROC curves was performed using the STAR online application. ${ }^{35}$

\section{Results}

\section{Patient characteristics by troponin categories}

Baseline characteristics, as divided by troponin categories, are shown in Table 1. Overall, patients with elevated cTnT concentrations were older and more likely to be male, to have a history of HF, CAD or diabetes mellitus and to be on diuretics prior to presentation. Additionally, these patients had more elevated NT-proBNP and creatinine concentrations, lower LVEF and more severe dyspnoea at presentation reflected by NYHA classification. Considering the final diagnosis of dyspnoea, patients with elevated CTnT concentrations were more often diagnosed with acutely decompensated heart failure and ACS or angina pectoris.

\section{Distribution of Troponin T concentrations}

Figure 1 shows the distribution of troponin $\mathrm{T}$ values measured with the hs-cTnT assay in this dyspnoea population $(n=678)$ and in a reference population of 477 apparently healthy subjects described previously.28, 29 In our dyspnoea population, troponin $\mathrm{T}$ concentrations were detectable (i.e. $\geq 0.003 \mu \mathrm{g} / \mathrm{L}$ ) in almost all patients utilizing the hs-cTnT assay $(\mathrm{n}=648 ; 95.6 \%)$, whereas with the cTnT assay, nearly half of the patients $(n=331 ; 48.8 \%, P<0.001)$ had detectable concentrations (i.e. $\geq 0.01$ $\mu \mathrm{g} / \mathrm{L}$ ). Troponin $\mathrm{T}$ concentrations were elevated according to the cTnT assay (i.e. $\geq 0.03 \mu \mathrm{g} / \mathrm{L})$ in 223 patients $(32.9 \%)$ whereas 506 patients $(74.6 \%)$ had elevated concentrations according to the hs-cTnT assay (i.e. $\geq 0.016 \mu \mathrm{g} / \mathrm{L}$ ). In patients with undetectable cTnT (i.e. $<0.01 \mu \mathrm{g} / \mathrm{L} ; \mathrm{n}=337$ ), hs-cTnT was detectable in 317 (91.4\%) and elevated (i.e. $\geq 0.016 \mu \mathrm{g} / \mathrm{L}$ ) in $180(51.9 \%)$ patients. 


\section{Chapter 3}

Table 1: Baseline characteristics

\begin{tabular}{|c|c|c|c|c|c|}
\hline Characteristics & Overall & $\begin{array}{c}\text { Troponin } \\
\text { category } \mathbf{1} \\
H_{s} c T n T \\
<0.016 \mu g / L\end{array}$ & $\begin{array}{c}\text { Troponin } \\
\text { category } \mathbf{2} \\
c T n T<0.03 \mu \mathrm{g} / \mathrm{L} \\
\text { and } \mathrm{hs}- \\
T n T \geq 0.016 \mu \mathrm{g} / \mathrm{L}\end{array}$ & $\begin{array}{c}\text { Troponin } \\
\text { category } \mathbf{3} \\
c T n T \geq 0.03 \mu g / L \text { and } \\
h s-c T n T \geq 0.016 \mu g / L\end{array}$ & $\mathbf{P}$ \\
\hline & Value & Value & Value & Value & \\
\hline Age (years) & $75 \pm 12$ & $67 \pm 15$ & $77 \pm 10$ & $78 \pm 10$ & $<0.001^{\mathrm{a}, \mathrm{b}}$ \\
\hline Male gender (\%) & $373(55 \%)$ & $88(51 \%)$ & $143(51 \%)$ & $142(64 \%)$ & $0.006^{\mathrm{b}, \mathrm{c}}$ \\
\hline \multicolumn{6}{|l|}{ Medical history: } \\
\hline Heart failure & $241(36 \%)$ & $43(25 \%)$ & $103(36 \%)$ & $95(43 \%)$ & $0.001^{\mathrm{a}, \mathrm{b}}$ \\
\hline Ischemic etiology & $157(65 \%)$ & $23(53 \%)$ & $68(66 \%)$ & $66(69 \%)$ & 0.182 \\
\hline Coronary artery disease & $312(46 \%)$ & $63(37 \%)$ & $140(49 \%)$ & $109(49 \%)$ & $0.016^{\mathrm{a}, \mathrm{b}}$ \\
\hline Diabetes Mellitus & $194(29 \%)$ & $32(19 \%)$ & $88(32 \%)$ & $74(35 \%)$ & $0.001^{\mathrm{a}, \mathrm{b}}$ \\
\hline Atrial fibrillation & $216(32 \%)$ & $54(31 \%)$ & $91(32 \%)$ & $71(32 \%)$ & 0.989 \\
\hline COPD & $146(22 \%)$ & $29(17 \%)$ & $63(22 \%)$ & $54(24 \%)$ & 0.206 \\
\hline Hypertension & $386(69 \%)$ & $85(60 \%)$ & $175(75 \%)$ & $126(69 \%)$ & $0.008^{\mathrm{a}}$ \\
\hline $\operatorname{LVEF}(\%)$ & $43 \pm 17$ & $49 \pm 16$ & $42 \pm 16$ & $39 \pm 17$ & $<0.001^{a, b, c}$ \\
\hline \multicolumn{6}{|l|}{ Symptoms and signs at presentation: } \\
\hline Dyspnea at rest & $267(39 \%)$ & $56(33 \%)$ & $106(37 \%)$ & $105(47 \%)$ & $0.010^{\mathrm{b}, \mathrm{c}}$ \\
\hline \multicolumn{6}{|l|}{ Blood pressure: } \\
\hline Systolic (mmHg) & $138 \pm 29.1$ & $141 \pm 24.7$ & $139 \pm 30.9$ & $133 \pm 29.3$ & $0.025^{\mathrm{b}, \mathrm{c}}$ \\
\hline Diastolic (mmHg) & $74.8 \pm 17.3$ & $78.2 \pm 16.3$ & $74.9 \pm 18.4$ & $72.1 \pm 16.0$ & $0.003^{c}$ \\
\hline Heart rate $(\mathrm{bpm})$ & $92 \pm 28$ & $92 \pm 27$ & $88 \pm 27$ & $95 \pm 30$ & $0.023^{c}$ \\
\hline QRS-duration (ms) & $109 \pm 31.2$ & $97.1 \pm 24.2$ & $111 \pm 34.1$ & $114 \pm 30.0$ & $<0.001^{\mathrm{a}, \mathrm{b}}$ \\
\hline \multicolumn{6}{|l|}{ Laboratory results: } \\
\hline Hs-cTnT (pg/ml) & $\begin{array}{c}32.75 \\
(17.41-60.53)\end{array}$ & $\begin{array}{c}9.59 \\
(7.18-13.41)\end{array}$ & $\begin{array}{c}28.18 \\
(21.28-37.00)\end{array}$ & $\begin{array}{c}79.60 \\
(56.93-157.90)\end{array}$ & $<0.001^{a, b, c}$ \\
\hline $\mathrm{Hb}(\mathrm{mmol} / \mathrm{L})$ & $7.9 \pm 1.3$ & $8.4 \pm 1.0$ & $7.8 \pm 1.3$ & $7.7 \pm 1.3$ & $<0.001^{\mathrm{a}, \mathrm{b}}$ \\
\hline CRP (mg/L) & $\begin{array}{c}15.00 \\
(5.60-41.75)\end{array}$ & $\begin{array}{c}9.50 \\
(3.40-28.25)\end{array}$ & $\begin{array}{c}14.00 \\
(5.00-36.00)\end{array}$ & $\begin{array}{c}25.00 \\
(9,20-57.00)\end{array}$ & $<0.001^{b, c}$ \\
\hline Creatinine $(\mu \mathrm{mol} / \mathrm{L})$ & $\begin{array}{c}111 \\
(89-150)\end{array}$ & $\begin{array}{c}90 \\
(76-108)\end{array}$ & $\begin{array}{c}114 \\
(93-143)\end{array}$ & $\begin{array}{c}143 \\
(104-227)\end{array}$ & $<0.001^{a, b, c}$ \\
\hline NT-proBNP (pg/ml) & $\begin{array}{c}3174 \\
(989-8350)\end{array}$ & $\begin{array}{c}788 \\
(180-2476)\end{array}$ & $\begin{array}{c}3177 \\
(1186-7153)\end{array}$ & $\begin{array}{c}7525 \\
(2797-16864)\end{array}$ & $<0.001^{\mathrm{a}, \mathrm{b}, \mathrm{c}}$ \\
\hline \multicolumn{6}{|l|}{ Final diagnoses: } \\
\hline Acutely decompensated heart failure & $389(57 \%)$ & $52(30 \%)$ & $178(63 \%)$ & $159(71 \%)$ & $<0.01^{\mathrm{a}, \mathrm{b}}$ \\
\hline ACS or angina pectoris & $51(8 \%)$ & $10(6 \%)$ & $13(5 \%)$ & $28(13 \%)$ & $0.003^{\mathrm{b}, \mathrm{c}}$ \\
\hline Inflammatory pulmonary disease & $35(5 \%)$ & $16(9 \%)$ & $14(5 \%)$ & $5(2 \%)$ & $0.007^{\mathrm{b}}$ \\
\hline Rhythm and conduction disturbances & $48(7 \%)$ & $16(9 \%)$ & $19(7 \%)$ & $13(6 \%)$ & 0.38 \\
\hline Other & $55(8 \%)$ & $23(13 \%)$ & $20(7 \%)$ & $12(5 \%)$ & $0.015^{\mathrm{a}, \mathrm{b}}$ \\
\hline Dyspnea of unknown cause & $100(15 \%)$ & $55(32 \%)$ & $39(14 \%)$ & $6(3 \%)$ & $<0.001^{a, b, c}$ \\
\hline \multicolumn{6}{|l|}{ Medication at presentation: } \\
\hline Diuretics & $403(60 \%)$ & $78(46 \%)$ & $181(66 \%)$ & $144(65 \%)$ & $<0.001^{\mathrm{a}, \mathrm{b}}$ \\
\hline ACEi of ARB & $384(57 \%)$ & $88(52 \%)$ & $177(64 \%)$ & $119(54 \%)$ & $0.013^{\mathrm{a}, \mathrm{c}}$ \\
\hline$\beta$-blockers & $372(56 \%)$ & $88(52 \%)$ & $166(60 \%)$ & $118(53 \%)$ & 0.142 \\
\hline Aldosterone antagonist & $55(8 \%)$ & $11(6 \%)$ & $27(10 \%)$ & $17(8 \%)$ & 0.463 \\
\hline $\mathrm{OAC}$ & $252(38 \%)$ & $58(34 \%)$ & $107(39 \%)$ & $87(39 \%)$ & 0.531 \\
\hline Digitalis & $86(13 \%)$ & $14(8 \%)$ & $37(13 \%)$ & $35(16 \%)$ & $0.077^{c}$ \\
\hline
\end{tabular}

ACEi=angiotensine converting enzyme inhibitor; $A C S=a c u t e$ coronary syndrome; $A R B=$ angiotensin receptor blocker; $C O P D=$ chronic obstructive pulmonary disease; $C R P=C$-reactive protein; Hb=haemoglobin; hs-cTnT=highly sensitive cardiac troponin $T ; L V E F=l e f t$ ventricular ejection fraction; $N T$-proBNP $=N$-terminal pro-brain natriuretic peptide; OAC=oral anticoagulation. ${ }^{a} P<0.05$ for comparing group 1 versus $2 ;{ }^{b} P<0.05$ for comparing group 1 versus $3 ;{ }^{c} P<0.05$ for comparing group 2 versus 3.Data are presented as mean $\pm S D$, median (interquartile range) or as frequencies with percentages. 


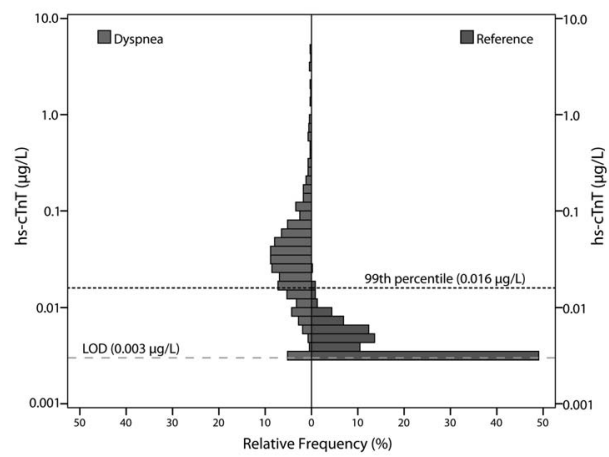

Figure 1. Relative distribution of hs-cTnT values in our dyspnoea cohort $(\mathrm{n}=678)$ and in a healthy reference population $(n=477)$.

\section{Highly sensitive versus conventional troponin $\mathrm{T}$ for predicting early outcome}

More than half of the patients ( $\mathrm{n}=398 ; 57.4 \%)$ were admitted following presentation to the emergency department. Ninety days follow-up was complete in all patients. After 90-days, 89 patients (13.1\%) had died, of which 68 (76.4\%) from cardiovascular causes. The number of admissions following presentation and short-term mortality rates increased over the troponin categories (table 2). Both the second and third troponin category was associated with 90-day mortality (table 3).

Table 2. Event rates in cardiac troponin categories.

\begin{tabular}{lcccc}
\hline & $\begin{array}{c}\text { Troponin } \\
\text { category } \mathbf{1}\end{array}$ & $\begin{array}{c}\text { Troponin } \\
\text { category } \mathbf{2}\end{array}$ & $\begin{array}{c}\text { Troponin } \\
\text { category 3 }\end{array}$ & $\mathbf{P}$ \\
\hline Admission following presentation & $59(34 \%)$ & $166(59 \%)$ & $173(78 \%)$ & $<0.001^{\mathrm{a}, \mathrm{b}, \mathrm{c}}$ \\
Lenght of stay in days (IQR) & $5(3-8)$ & $6(4-10)$ & $7(4-12)$ & $<0.001^{\mathrm{a}, \mathrm{b}, \mathrm{c}}$ \\
In hospital mortality & $1(1 \%)$ & $9(3 \%)$ & $22(10 \%)$ & $<0.001^{\mathrm{a}, \mathrm{b}, \mathrm{c}}$ \\
30- days mortality & $2(1 \%)$ & $17(6 \%)$ & $39(18 \%)$ & $<0.001^{\mathrm{a}, \mathrm{b}, \mathrm{c}}$ \\
90- days mortality & $4(2 \%)$ & $27(10 \%)$ & $58(26 \%)$ & $<0.001^{\mathrm{a}, \mathrm{b}, \mathrm{c}}$ \\
1- year mortality & $14(9 \%)$ & $50(21 \%)$ & $73(39 \%)$ & $<0.001^{\mathrm{a}, \mathrm{b}, \mathrm{c}}$ \\
\hline
\end{tabular}

Data are presented as median (interquartile range, IQR) or as frequencies with percentages. ${ }^{\text {a }}<0.05$ for comparing group 1 versus 2 ; ${ }^{\mathrm{b}} \mathrm{P}<0.05$ for comparing group 1 versus 3 ; $\mathrm{P}<0.05$ for comparing group 2 versus 3

Table 3. Association of cardiac troponin categories with 90-day and 1-year mortality

\begin{tabular}{cllll}
\hline & Unadjusted & & Adjusted & \\
\hline 90-day mortality & OR (95\%CI) & $\mathbf{P}$ & OR (95\%CI) & $\mathbf{P}$ \\
Troponin category 2 & $4.43(1.52-12.89)$ & 0.006 & $2.50(0.83-7.56)$ & 0.11 \\
Troponin category 3 & $14.76(5.24-41.59)$ & $<0.001$ & $6.24(2.07-18.82)$ & 0.001 \\
1-year mortality & HR (95\%CI) & $\mathbf{P}$ & HR (95\%CI) & $\mathbf{P}$ \\
Troponin category 2 & $2.53(1.44-4.47)$ & 0.001 & $1.46(0.81-2.61)$ & 0.21 \\
Troponin category 3 & $5.79(3.35-10.01)$ & $<0.001$ & $2.72(1.50-4.93)$ & 0.001 \\
\hline
\end{tabular}

$\mathrm{HR}=$ hazard ratio; $\mathrm{CI}=$ confidence interval; $\mathrm{OR}=\mathrm{Odd}$ ratio. Hazard and Odds ratios are for comparison with troponin category 1 as a reference category. Adjustments were made for age, gender, dyspnea NYHA IV, history of heart failure, systolic blood pressure, left ventricular ejection fraction and creatinine level. 
After correction for traditional clinical risk factors this only remained true for the third troponin category. When using troponin concentrations as a continuous variable, a strong association with 90-day mortality was present, independent of traditional risk factors and irrespective of the assay used (table 4).

Table 4. Incremental prognostic value of biomarkers on top of clinical risk factors for 90-day mortality.

\begin{tabular}{|c|c|c|c|c|c|c|}
\hline & & Selection & $\begin{array}{l}\text { Hosmer- } \\
\text { Lemeshow }\end{array}$ & Discrimination & & \\
\hline Model & OR $(95 \%)$ & $\chi^{2}$ & $\mathrm{P}^{* *}$ & C-index $(95 \% \mathrm{CI})$ & IDI & NRI \\
\hline $\begin{array}{l}\text { Model 1: Clinical } \\
\text { risk factors* }\end{array}$ & & 84.8 & 0.55 & $0.787(0.741-0.833)$ & & \\
\hline+ Hs-cTnT & $1.64(1.34-2.01)^{\mathrm{a}}$ & $107.5^{\mathrm{a}}$ & 0.52 & $0.817(0.774-0.860)^{\mathrm{b}}$ & $4.2 \% \mathrm{a}^{\mathrm{a}}$ & $12.9 \%^{\mathrm{b}}$ \\
\hline$+\mathrm{cTnT}$ & $1.44(1.24-1.68)^{\mathrm{a}}$ & $106.8^{\mathrm{a}}$ & 0.25 & $0.815(0.771-0.859)^{\mathrm{b}}$ & $4.4 \%{ }^{\mathrm{a}}$ & $13.7 \%^{\mathrm{b}}$ \\
\hline+ NT-proBNP & $1.59(1.28-1.96)^{a}$ & $105.0^{\mathrm{a}}$ & 0.78 & $0.811(0.766-0.855)$ & $3.9 \%$ & $17.0 \% \mathrm{~b}$ \\
\hline$+\mathrm{CRP}$ & $1.60(1.31-1.95)^{\mathrm{a}}$ & $107.0^{\mathrm{a}}$ & 0.98 & $0.816(0.771-0.861)^{\mathrm{b}}$ & $4.4 \% \mathrm{a}$ & $12.3 \%^{\mathrm{b}}$ \\
\hline
\end{tabular}

$\mathrm{CRP}=\mathrm{C}$-reactive protein; $\mathrm{cTnT}=$ cardiac troponin $\mathrm{T}$; hs-cTnT=highly sensitive cardiac troponin $\mathrm{T}$; IDI=integrated discrimination improvement; NRI=net reclassification index; NT-proBNP=N-terminal pro-brain natriuretic peptide; $\mathrm{OR}=\mathrm{odds}$ ratio. Hs-cTnT, cTnT, NT-proBNP and CRP were added separately to model 1 as log-transformed continuous variables. Odds ratios are for each unit increase in the natural logarithm. * Including age, gender, dyspnea NYHA IV, history of heart failure, C-reactive protein, systolic blood pressure, left ventricular ejection fraction and creatinine level. ${ }^{* *}$ A $\mathrm{P}<0.05$ for the Hosmer-Lemeshow statistic indicates a significant difference between predicted versus observer probability, whereas a high $\mathrm{P}$-value indicates a good model fit. a $\mathrm{P}<0.001$ compared to model 1 . $^{\mathrm{b}}$ $\mathrm{P}<0.05$ compared to model 1 .

This remained true after correction for traditional clinical risk factors plus NTproBNP and CRP (OR=1.34, 95\% CI 1.07-1.68, $\mathrm{P}=0.012$ for hs-cTnT and $\mathrm{OR}=1.24$, 95\% CI 1.05-1.47, $\mathrm{P}=0.012$ for cTnT). Hs-cTnT, cTnT, NT-proBNP and CRP all had similar incremental value in predicting 90-day mortality beyond clinical risk factors according to AUC, NRI and IDI (table 5). The combination of any two biomarkers did not further improve model discrimination beyond the models with one single biomarker (data not shown). ROC-curve analysis for the estimation of 90-day mortality in figure 2 illustrates that hs-cTnT, cTnT, NT-proBNP and CRP have comparable prognostic accuracy of 90-day mortality $(\mathrm{P}>0.1$ for all comparisons). The predefined cut-off value of $0.016 \mu \mathrm{g} / \mathrm{L}$ for hs-cTnT showed a higher prognostic sensitivity (96\%) and negative predictive value (98\%) compared to those for the cTnT cut-off of $0.03 \mu \mathrm{g} / \mathrm{L}$ (65\% and $93 \%$, respectively), at the expense of lower specificity and positive predictive value (table 5). 


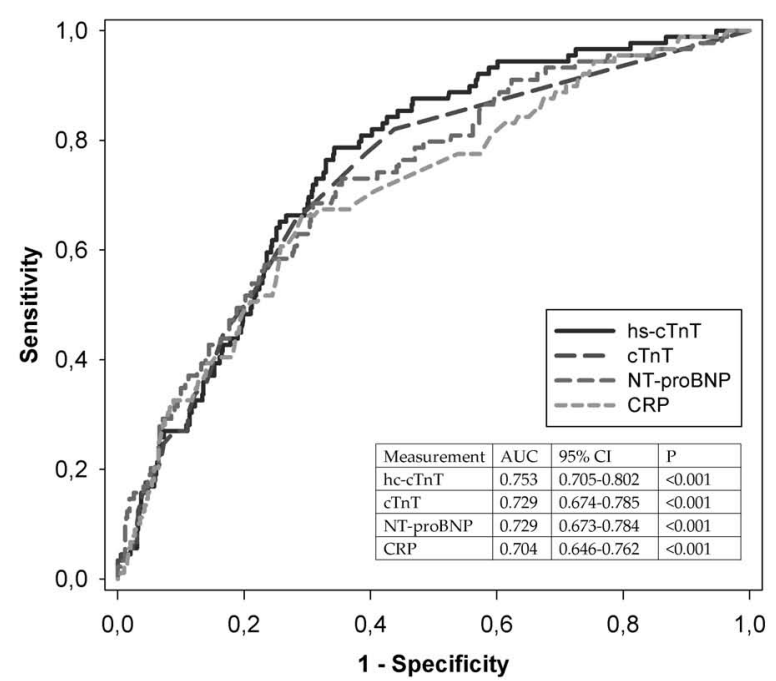

Figure 2. ROC-curves for the prognostic accuracy of hs-cTnT, cTnT, NT-proBNP, and CRP for 90-day mortality with corresponding area's under the curve.

Table 5. Predictive performance of cardiac biomarkers at cut-offs for elevation.

\begin{tabular}{lllll}
\hline & Sensitivity & Specificity & PPV & NPV \\
\hline hs-cTnT (0.016 ug/L) & $96 \%$ & $29 \%$ & $17 \%$ & $98 \%$ \\
cTnT (0.03 ug/L) & $65 \%$ & $72 \%$ & $26 \%$ & $93 \%$ \\
NT-proBNP (900 pg/ml) & $94 \%$ & $26 \%$ & $16 \%$ & $97 \%$ \\
\hline
\end{tabular}

$\mathrm{cTnT}=$ cardiac troponin $\mathrm{T} ; \mathrm{hs}-\mathrm{cTnT}=$ highly sensitive cardiac troponin $\mathrm{T} ; \mathrm{NPV}=$ negative predictive value; NTproBNP=N-terminal pro-brain natriuretic peptide; $\mathrm{PPV}=$ positive predictive value.

\section{Hs-cTnT for predicting long-term mortality}

Complete 1-year follow-up data were available in 606 (89.3\%) patients. Of the remaining 72 patients, 70 patients had a follow-up of at least 6 months (2 patients emigrated, leaving no means of contact). Data was censored at the time of last contact. At one year, 162 (23.9\%) patients had died, of which 118 (72.8\%) from cardiovascular causes. Cumulative survival rates over time are shown in figure 3, showing a reduced survival in the second and third troponin category. The association of troponin $\mathrm{T}$ with mortality was maintained over the long-term and was similar to short-term results, as depicted in table 3 . When using troponin concentrations as a continuous variable, regression analysis confirmed a strong association for hs-cTnT with 1-year mortality, even after correction for clinical risk factors (HR=1.35; 95\% CI 1.18-1.53; $\chi^{2} 20.1 ; \mathrm{P}<0.001$ per logarithmic unit increase) 
and for clinical risk factors plus NT-proBNP and CRP (HR=1.17; 95\% CI 1.01-1.35; $\chi^{2} 4.4 ; \mathrm{P}=0.037$ per logarithmic unit increase).

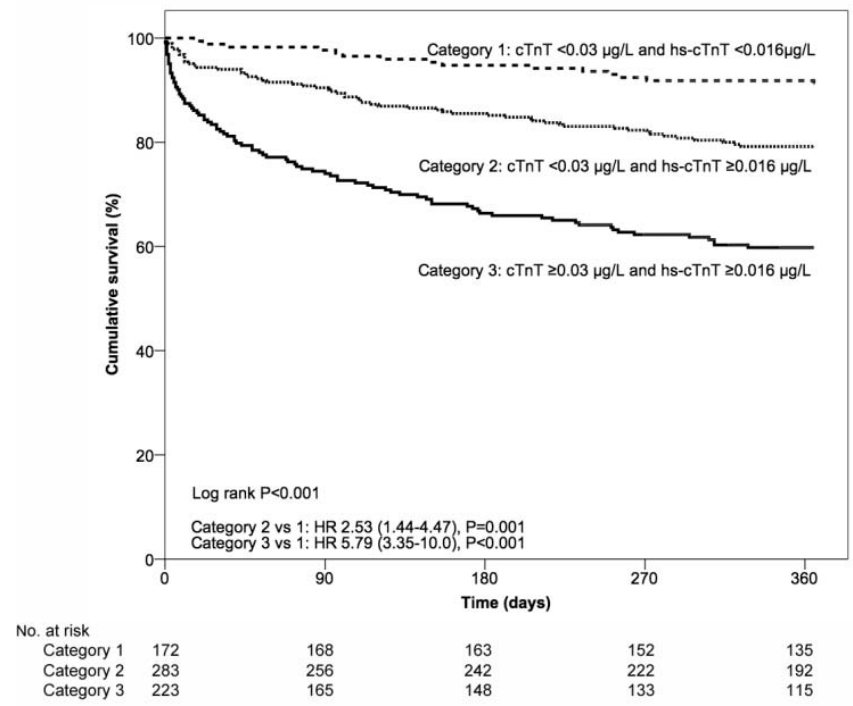

Figure 3: Kaplan-Meier survival curves for all-cause mortality according to the three troponin categories.

\section{Patients with undetectable cTnT by the conventional assay}

In patients with undetectable cTnT (i.e. $<0.01 \mu \mathrm{g} / \mathrm{L} ; \mathrm{n}=347$ ) by the conventional assay, $16(4.6 \%)$ patients had died within 90 days and $41(11.8 \%)$ had died at 1 -year follow-up. Hs-TnT was elevated $\geq 0.016 \mu \mathrm{g} / \mathrm{L}$ in 180 of 347 patients $(51.9 \%)$ and this cut-off identified patients at risk of 90-day (OR=4.26, 95\% CI: 1.19-15.21, $\mathrm{P}=0.026)$ and 1-year mortality $(\mathrm{HR}=2.27,95 \% \mathrm{CI}: 1.19-4.36, \mathrm{P}=0.013)$. In this subgroup of patients with previously undetectable troponin $\mathrm{T}$ concentrations, hs-cTnT was the only biomarker independently associated with 90-day mortality (OR=3.61, 95\% CI 1.20-10.83 $\mathrm{P}=0.022$ per logarithmic unit increase, corrected for clinical risk factors) and the only biomarker with a significant prognostic accuracy for 90-day mortality (AUC=0.733, 95\% CI 0.617-0.849, $\mathrm{P}=0.002$ ). 


\section{Discussion}

In our cohort of 678 patients presenting with dyspnoea to the emergency department, we found that (i) troponin $\mathrm{T}$ is strongly associated with both 90-day and 1-year mortality, independently of traditional clinical risk factors plus NTproBNP and CRP, (ii) the hs-cTnT assay has additional prognostic value beyond conventional cTnT and NT-proBNP in the range where troponin $\mathrm{T}$ is not elevated or not detectable according to the cTnT assay, and (iii) the hs-cTnT cut-off of 0.016 $\mu \mathrm{g} / \mathrm{L}$ enables identification of subjects with excellent prognosis and improves risk stratification beyond the conventional cTnT assay.

As it may be expected, in patients with both detectable cTnT and hs-cTnT measurements, the prognostic value of these assays was comparable. Nonetheless, additional value of the hs-cTnT assay on top of the conventional assay could clearly be shown in subjects with undetectable cTnT concentrations $(<0.01 \mu \mathrm{g} / \mathrm{L})$, given that in patients with undetectable cTnT, hs-cTnT was the only biomarker predictive of an elevated risk of death. Interestingly, hs-cTnT was elevated $\geq 0.016$ $\mu \mathrm{g} / \mathrm{L}$ in more than half of the patients with undetectable cTnT concentrations, showing the discrepancy of the assays in the low range. In line with our findings, very low cTnT concentrations measured by the highly sensitive assay have recently been shown to be a powerful predictor and discriminator of outcome in patients with ESRD, ${ }^{36}$ stable $\mathrm{HF}^{15}$ stable $\mathrm{CAD}^{14}$ and even in community-dwelling populations. ${ }^{37-39}$ An important difference with these previous studies is that in our study, nearly half $(48.8 \%)$ of the patients had measurable cTnT concentrations, whereas in the former studies only a minority of patients had detectable cTnT concentrations. Therefore, the additive value of the highly sensitive assay on top of the conventional assay might have been more difficult to identify in our study. Despite this, the hs-cTnT cut-off of $0.016 \mu \mathrm{g} / \mathrm{L}$ showed excellent prognostic sensitivity and negative predictive value in our study and allowed risk stratification beyond the conventional cTnT cut-off. That is, the hs-cTnT cut-off allowed identification of patients with a truly low risk of 90-day and 1-year mortality (troponin category 1). Patients with 'negative' cTnT values according to the conventional assay $(<0.03 \mu \mathrm{g} / \mathrm{L})$ on the other hand do not necessarily have a benign prognosis. In these patients, who were previously thought to be low-risk, 
the hs-cTnT assay enabled differentiation between troponin category 2 and 3, which have very different outcomes (table 2 and figure 3 ). Thus, we show here that the hs-cTnT assay can help to stratify risk in patients with acute dyspnoea and particularly, for clinical decision making, that the cut-off of $0.016 \mu \mathrm{g} / \mathrm{L}$ enables identification of truly low-risk patients who might be evaluated safely in an outpatient setting. Similar results were recently seen in patients with non-high risk pulmonary embolism. ${ }^{16}$ We now extend these results to a more general and heterogeneous population with acute dyspnoea. This is a population that is commonly encountered at emergency departments, 18,19 wherein making a quick and safe decision is of particular importance and may allow saving of resources. Brain natriuretic peptides are nowadays the most widely used biomarkers for risk stratification in patients with acute dyspnoea. ${ }^{20-22,40,41}$ Although we confirm the excellent prognostic value of NT-proBNP in these patients, the prognostic performance of hs-cTnT in our cohort was overall similar to that of NT-proBNP and even exceeded that of NT-proBNP and CRP within the patients with undetectable cTnT concentrations. Furthermore, hs-cTnT was associated with 90day and 1-year mortality independent of traditional risk factors plus NT-proBNP and CRP and hs-cTnT had incremental value on top of clinical risk factors (table 4). Additional prognostic value of hs-cTnT on top of clinical risk factors was also seen in chronic HF and stable CAD. ${ }^{14,15}$ Although the incremental value of hs-cTnT in our study seems modest considering the relatively small increase in AUC of 0.03, the combination of several risk prediction methods (NRI, IDI, C-statistic) according to recent recommendations ${ }^{33}$ provides robust documentation of the incremental value of hs-cTnT. It should also be noted in this regard that our baseline clinical model already had strong prognostic performance (AUC 0.787), making it more difficult to show incremental value. There are several limitations to our study. Firstly, our study was performed in a single centre emergency department. Secondly, the number of patients and events was relatively small, especially in the subgroup of patients with undetectable cTnT, limiting the number of predictors that could be included. Nonetheless, we corrected for seven traditional risk factors in multivariate analysis. Sample size issues also precluded stratified analysis among patient subgroups. Taking this together, it will be of interest to validate our findings in another, preferably larger cohort. Finally, one must take into 
consideration that as a result of using a more sensitive assay, specificity is reduced. Also, our study did not directly assess the impact of hs-cTnT levels on the management of patients. Therefore, the therapeutic consequences of using the hscTnT assay in clinical practice for immediate stratifying patients with dyspnoea need prospective evaluation.

In conclusion, cardiac troponin $\mathrm{T}$ concentrations measured by the hs-cTnT assay are of prognostic value in patients presenting with acute dyspnoea and provide additional prognostic information when compared to conventional troponin testing and NT-proBNP testing. In particular, regarding clinical decision making, results of hs-cTnT below the cut-off of $0.016 \mu \mathrm{g} / \mathrm{L}$ enable identification of low-risk patients, whereas patients above this cut-off have a substantial risk even if conventional $\mathrm{cTnT}$ is not detectable.

\section{Acknowledgements}

We are grateful to Vincent Kleijnen for his help with the laboratory analyses.

\section{References}

1. Alpert JS, Thygesen K, Antman E, Bassand JP. Myocardial infarction redefined--a consensus document of the joint european society of cardiology/american college of cardiology committee for the redefinition of myocardial infarction. J Am Coll Cardiol. 2000;36:959-969

2. Morrow DA, Cannon CP, Jesse RL, Newby LK, Ravkilde J, Storrow AB, Wu AH, Christenson RH. National academy of clinical biochemistry laboratory medicine practice guidelines: Clinical characteristics and utilization of biochemical markers in acute coronary syndromes. Circulation. 2007;115:e356-375

3. Hamm CW, Giannitsis E, Katus HA. Cardiac troponin elevations in patients without acute coronary syndrome. Circulation. 2002;106:2871-2872

4. Kelley WE, Januzzi JL, Christenson RH. Increases of cardiac troponin in conditions other than acute coronary syndrome and heart failure. Clinical chemistry. 2009;55:2098-2112

5. Miller WL, Hartman KA, Burritt MF, Grill DE, Jaffe AS. Profiles of serial changes in cardiac troponin $\mathrm{t}$ concentrations and outcome in ambulatory patients with chronic heart failure. Journal of the American College of Cardiology. 2009;54:1715-1721

6. Peacock WFt, De Marco T, Fonarow GC, Diercks D, Wynne J, Apple FS, Wu AH. Cardiac troponin and outcome in acute heart failure. N Engl J Med. 2008;358:2117-2126

7. Perna ER, Macin SM, Canella JP, Augier N, Stival JL, Cialzeta JR, Pitzus AE, Garcia EH, Obregon R, Brizuela M, Barbagelata A. Ongoing myocardial injury in stable severe heart failure: Value of cardiac troponin $\mathrm{t}$ monitoring for high-risk patient identification. Circulation. 2004;110:2376-2382

8. Setsuta K, Seino Y, Ogawa T, Arao M, Miyatake Y, Takano T. Use of cytosolic and myofibril markers in the detection of ongoing myocardial damage in patients with chronic heart failure. Am J Med. 2002;113:717-722. 


\section{Chapter 3}

9. Khan NA, Hemmelgarn BR, Tonelli M, Thompson CR, Levin A. Prognostic value of troponin $t$ and $\mathrm{i}$ among asymptomatic patients with end-stage renal disease: A meta-analysis. Circulation. 2005;112:3088-3096

10. Sommerer C, Beimler J, Schwenger V, Heckele N, Katus HA, Giannitsis E, Zeier M. Cardiac biomarkers and survival in haemodialysis patients. Eur J Clin Invest. 2007;37:350-356

11. van den Bos EJ, Constantinescu AA, van Domburg RT, Akin S, Jordaens LJ, Kofflard MJ. Minor elevations in troponin $\mathrm{i}$ are associated with mortality and adverse cardiac events in patients with atrial fibrillation. European heart journal. 2011;32:611-7

12. Giannitsis E, Kurz K, Hallermayer K, Jarausch J, Jaffe AS, Katus HA. Analytical validation of a high-sensitivity cardiac troponin $\mathrm{t}$ assay. Clin Chem. 2010;56:254-261

13. $\mathrm{Wu} \mathrm{AH}$. Biochemical markers of cardiac damage: From traditional enzymes to cardiac-specific proteins. Ifcc subcommittee on standardization of cardiac markers (s-scm). Scandinavian journal of clinical and laboratory investigation. 1999;230:74-82

14. Latini R, Masson S, Anand IS, Missov E, Carlson M, Vago T, Angelici L, Barlera S, Parrinello G, Maggioni AP, Tognoni G, Cohn JN. Prognostic value of very low plasma concentrations of troponin $\mathrm{t}$ in patients with stable chronic heart failure. Circulation. 2007;116:1242-1249

15. Omland T, de Lemos JA, Sabatine MS, Christophi CA, Rice MM, Jablonski KA, Tjora S, Domanski MJ, Gersh BJ, Rouleau JL, Pfeffer MA, Braunwald E. A sensitive cardiac troponin t assay in stable coronary artery disease. N Engl J Med. 2009;361:2538-2547

16. Lankeit M, Friesen D, Aschoff J, Dellas C, Hasenfuss G, Katus H, Konstantinides S, Giannitsis E. Highly sensitive troponin $\mathrm{t}$ assay in normotensive patients with acute pulmonary embolism. European heart journal. 2010;31:1836-1844

17. Reichlin T, Hochholzer W, Bassetti S, Steuer S, Stelzig C, Hartwiger S, Biedert S, Schaub N, Buerge C, Potocki M, Noveanu M, Breidthardt T, Twerenbold R, Winkler K, Bingisser R, Mueller C. Early diagnosis of myocardial infarction with sensitive cardiac troponin assays. $N$ Engl J Med. 2009;361:858-867

18. Manning HL, Schwartzstein RM. Pathophysiology of dyspnea. The New England journal of medicine. 1995;333:1547-1553

19. Michelson E, Hollrah S. Evaluation of the patient with shortness of breath: An evidence based approach. Emergency medicine clinics of North America. 1999;17:221-237, x

20. Christ M, Thuerlimann A, Laule K, Klima T, Hochholzer W, Perruchoud AP, Mueller C. Long-term prognostic value of b-type natriuretic peptide in cardiac and non-cardiac causes of acute dyspnoea. European journal of clinical investigation. 2007;37:834-841

21. Gegenhuber A, Mueller T, Dieplinger B, Poelz W, Pacher R, Haltmayer M. B-type natriuretic peptide and amino terminal probnp predict one-year mortality in short of breath patients independently of the baseline diagnosis of acute destabilized heart failure. Clinica chimica acta; international journal of clinical chemistry. 2006;370:174-179

22. Januzzi JL, Jr., Sakhuja R, O'Donoghue M, Baggish AL, Anwaruddin S, Chae CU, Cameron R, Krauser DG, Tung R, Camargo CA, Jr., Lloyd-Jones DM. Utility of amino-terminal pro-brain natriuretic peptide testing for prediction of 1-year mortality in patients with dyspnea treated in the emergency department. Archives of internal medicine. 2006;166:315-320

23. Ordonez-Llanos J, Merce-Muntanola J, Santalo-Bel M. Natriuretic peptide testing in emergency settings. Clin Chem Lab Med. 2008;46:1543-1549

24. Rehman SU, Martinez-Rumayor A, Mueller T, Januzzi JL, Jr. Independent and incremental prognostic value of multimarker testing in acute dyspnea: Results from the probnp investigation of dyspnea in the emergency department (pride) study. Clinica chimica acta; international journal of clinical chemistry. 2008;392:41-45

25. van Kimmenade RR, Januzzi JL, Jr., Ellinor PT, Sharma UC, Bakker JA, Low AF, Martinez A, Crijns HJ, MacRae CA, Menheere PP, Pinto YM. Utility of amino-terminal pro-brain natriuretic peptide, 
galectin-3, and apelin for the evaluation of patients with acute heart failure. Journal of the American College of Cardiology. 2006;48:1217-1224

26. Dieplinger B, Gegenhuber A, Kaar G, Poelz W, Haltmayer M, Mueller T. Prognostic value of established and novel biomarkers in patients with shortness of breath attending an emergency department. Clinical biochemistry. 2010;43:714-719

27. Maisel A, Mueller C, Nowak R, Peacock WF, Landsberg JW, Ponikowski P, Mockel M, Hogan C, Wu AH, Richards M, Clopton P, Filippatos GS, Di Somma S, Anand I, Ng L, Daniels LB, Neath SX, Christenson R, Potocki M, McCord J, Terracciano G, Kremastinos D, Hartmann O, von Haehling S, Bergmann A, Morgenthaler NG, Anker SD. Mid-region pro-hormone markers for diagnosis and prognosis in acute dyspnea: Results from the bach (biomarkers in acute heart failure) trial. Journal of the American College of Cardiology. 2010;55:2062-2076

28. Jacobs LH, van de Kerkhof J, Mingels AM, Kleijnen VW, van der Sande FM, Wodzig WK, Kooman JP, van Dieijen-Visser MP. Haemodialysis patients longitudinally assessed by highly sensitive cardiac troponin $\mathrm{t}$ and commercial cardiac troponin $\mathrm{t}$ and cardiac troponin $\mathrm{i}$ assays. Ann Clin Biochem. 2009;46:283-290

29. Mingels A, Jacobs L, Michielsen E, Swaanenburg J, Wodzig W, van Dieijen-Visser M. Reference population and marathon runner sera assessed by highly sensitive cardiac troponin $t$ and commercial cardiac troponin $\mathrm{t}$ and $\mathrm{i}$ assays. Clin Chem. 2009;55:101-108

30. Thygesen K, Alpert JS, White HD, Jaffe AS, Apple FS, Galvani M, Katus HA, Newby LK, Ravkilde J, Chaitman B, Clemmensen PM, Dellborg M, Hod H, Porela P, Underwood R, Bax JJ, Beller GA, Bonow R, Van der Wall EE, Bassand JP, Wijns W, Ferguson TB, Steg PG, Uretsky BF, Williams DO, Armstrong PW, Antman EM, Fox KA, Hamm CW, Ohman EM, Simoons ML, Poole-Wilson PA, Gurfinkel EP, Lopez-Sendon JL, Pais P, Mendis S, Zhu JR, Wallentin LC, Fernandez-Aviles F, Fox KM, Parkhomenko AN, Priori SG, Tendera M, Voipio-Pulkki LM, Vahanian A, Camm AJ, De Caterina R, Dean V, Dickstein K, Filippatos G, Funck-Brentano C, Hellemans I, Kristensen SD, McGregor K, Sechtem U, Silber S, Tendera M, Widimsky P, Zamorano JL, Morais J, Brener S, Harrington R, Morrow D, Lim M, Martinez-Rios MA, Steinhubl S, Levine GN, Gibler WB, Goff D, Tubaro M, Dudek D, Al-Attar N. Universal definition of myocardial infarction. Circulation. 2007;116:2634-2653

31. Januzzi JL, Jr., Camargo CA, Anwaruddin S, Baggish AL, Chen AA, Krauser DG, Tung R, Cameron R, Nagurney JT, Chae CU, Lloyd-Jones DM, Brown DF, Foran-Melanson S, Sluss PM, LeeLewandrowski E, Lewandrowski KB. The n-terminal pro-bnp investigation of dyspnea in the emergency department (pride) study. Am J Cardiol. 2005;95:948-954

32. Dunlay SM, Gerber Y, Weston SA, Killian JM, Redfield MM, Roger VL. Prognostic value of biomarkers in heart failure: Application of novel methods in the community. Circ Heart Fail. 2009;2:393-400

33. Hlatky MA, Greenland P, Arnett DK, Ballantyne CM, Criqui MH, Elkind MS, Go AS, Harrell FE, Jr., Hong Y, Howard BV, Howard VJ, Hsue PY, Kramer CM, McConnell JP, Normand SL, O'Donnell CJ, Smith SC, Jr., Wilson PW. Criteria for evaluation of novel markers of cardiovascular risk: A scientific statement from the american heart association. Circulation. 2009;119:2408-2416

34. Pencina MJ, D'Agostino RB, Sr., D'Agostino RB, Jr., Vasan RS. Evaluating the added predictive ability of a new marker: From area under the roc curve to reclassification and beyond. Stat Med. 2008;27:157-172; discussion 207-112

35. Vergara IA, Norambuena T, Ferrada E, Slater AW, Melo F. Star: A simple tool for the statistical comparison of roc curves. BMC bioinformatics. 2008;9:265

36. McGill D, Talaulikar G, Potter JM, Koerbin G, Hickman PE. Over time, high-sensitivity tnt replaces nt-probnp as the most powerful predictor of death in patients with dialysis-dependent chronic renal failure. Clinica chimica acta; international journal of clinical chemistry. 2010;411:936-939 


\section{Chapter 3}

37. de Lemos JA, Drazner MH, Omland T, Ayers CR, Khera A, Rohatgi A, Hashim I, Berry JD, Das SR, Morrow DA, McGuire DK. Association of troponin $t$ detected with a highly sensitive assay and cardiac structure and mortality risk in the general population. Jama. 2011;304:2503-2512

38. deFilippi CR, de Lemos JA, Christenson RH, Gottdiener JS, Kop WJ, Zhan M, Seliger SL. Association of serial measures of cardiac troponin $t$ using a sensitive assay with incident heart failure and cardiovascular mortality in older adults. Jama. 2011;304:2494-2502

39. Otsuka T, Kawada T, Ibuki C, Seino Y. Association between high-sensitivity cardiac troponin $t$ levels and the predicted cardiovascular risk in middle-aged men without overt cardiovascular disease. American heart journal. 2010;159:972-978

40. Daniels LB, Maisel AS. Natriuretic peptides. Journal of the American College of Cardiology. 2007;50:2357-2368

41. Maisel A, Mueller C, Adams K, Jr., Anker SD, Aspromonte N, Cleland JG, Cohen-Solal A, Dahlstrom U, DeMaria A, Di Somma S, Filippatos GS, Fonarow GC, Jourdain P, Komajda M, Liu PP, McDonagh T, McDonald K, Mebazaa A, Nieminen MS, Peacock WF, Tubaro M, Valle R, Vanderhyden M, Yancy CW, Zannad F, Braunwald E. State of the art: Using natriuretic peptide levels in clinical practice. Eur J Heart Fail. 2008;10:824-839 


\title{
CHAPTER 4
}

\section{Reference population and marathon runner sera assessed by \\ highly sensitive cardiac troponin $T$ and commercial \\ cardiac troponin $T$ and I assays}

\begin{abstract}
SUMMARY
Background: Endurance exercise can increase cardiac troponin (cTn) concentrations as high as those seen in cases of minor myocardial infarction. The inability of most cTn assays to reliably quantify cTn at very low concentrations complicates a thorough data analysis, and the clinical implications of such increases remain unclear. The application of recently developed highly sensitive cTn immunoassays may help resolve these problems.
\end{abstract}

Methods: We evaluated the pre-commercial highly sensitive cardiac troponin $T$ (hscTnT) assay from Roche Diagnostics and the Architect cardiac troponin I (cTnIArchitect) assay from Abbott Diagnostics by testing samples from a reference population of 546 individuals and a cohort of 85 marathon runners. We also measured the samples with the current commercial cTnT assay for comparison.

Results: Although the hs-cTnT and cTnI-Architect assays were capable of measuring cTn concentrations at low concentrations $(<0.01 \mu \mathrm{g} / \mathrm{L})$, only the $\mathrm{hs}-\mathrm{cTnT}$ assay demonstrated a CV of $<10 \%$ at the $99^{\text {th }}$ percentile of the reference population and a near-gaussian distribution of the measurements. After a marathon, $86 \%$ of the runners had cTnT concentrations greater than the $99^{\text {th }}$ percentile with the hs-cTnT assay, whereas only $45 \%$ of the runners showed increased concentrations with the current cTnT assay. cTn concentrations remained significantly increased the day after the marathon. A multiple regression analysis demonstrated marathon experience and age to be significant predictors of post-marathon cTn concentrations $(P<0.05)$.

Conclusions: The hs-cTnT assay was the only assay tested with a performance capability sufficient to detect cTn concentrations in healthy individuals. The number of runners with increased cTn concentrations after a marathon depends highly on an assay's limit of detection (LOD). The assay with the lowest LOD, the hs-cTnT assay, showed that almost all runners had increased cTn concentrations. The clinical implications of these findings require further investigation.

Part of this work has been published in: Clinical Chemistry 2009; 55 (1):101-108: A. Mingels, L. Jacobs, E. Michielsen, J. Swaanenburg, W.Wodzig, M. van Dieijen-Visser. 


\section{Introduction}

Regular exercise is part of a healthy lifestyle and aids in the prevention of cardiovascular disease. ${ }^{1}$ In endurance exercise such as marathon running, however, physical collapse is frequently observed during and after races, and such collapses are often associated with coronary artery disease or left ventricular hypertrophy. ${ }^{1-3}$ The risk for such a cardiac event has been suggested to be comparable with that encountered in other daily activities and thus seems relatively low.2-4 Nevertheless, the concentrations of highly specific cardiac markers such as the cardiac troponins (cTn) are known to increase after prolonged exercise to concentrations similar to those seen after a minor myocardial infarction, ${ }^{5-9}$ as we have recently reviewed for cardiac troponin $\mathrm{T}(\mathrm{cTnT}) .{ }^{10}$ Because the consequences of cTn release are still unclear, the phenomenon of exerciseinduced cTn release is an active topic of discussion and requires further study.

The recent development of more sensitive cTnT and cTnI immunoassays and their evaluation in different clinical settings ${ }^{11-13}$ have prompted a redefinition of the diagnosis of acute myocardial infarction (AMI) as follows: an increase and/or decrease in the concentrations of cardiac markers, preferably cTnT or cTnI, should be documented by at least one observation above the $99^{\text {th }}$ percentile value of the reference population, and such results should be accompanied by clinical, electrocardiographic, or imaging findings. ${ }^{14}, 15$ Until recently, however, most cTn assays lacked an analytical performance sufficient to detect cTn concentrations in a reference population or to distinguish reference values from the analytical noise. The inadequacy of cTn assays can be attributed either to the limit of detection (LOD) of the cTn assay being higher than reference values or to assay imprecision (i.e., $\mathrm{CV}$ ) being $>10 \%$ at the $99^{\text {th }}$-percentile value of the reference population. ${ }^{16-18}$

Because of the wide variation in cTn assays, comparisons of previous studies of exercise-induced cTn release make sense only for studies that have used the same cTn immunoassay. Such comparisons are especially difficult for cTnI studies because, in contrast to the patented cTnT assay, the approximately 10-20 cTnI immunoassays that have been developed use different antibodies directed against different epitopes. ${ }^{14,16,17,19}$ In addition, the various assays use different calibrator and control materials. We previously demonstrated that the cTnT concentration 
increases after prolonged exercise by $59 \%$ on average. ${ }^{10}$ In brief, exercise-induced cTn release is characterized by a peak after the event is finished and a return to baseline concentrations within 1 day.10 In the presence of clinical symptoms, exercise-induced cTn release would be indicative of AMI and would require further investigation. The use of recently developed highly sensitive cTn assays may provide new insights into the exercise-induced release of cTn.

We studied the analytical performance of 2 recently introduced cTn assays, the pre-commercial highly sensitive cTnT (hs-cTnT) assay from Roche Diagnostics and the cTnI Architect (cTnI-Architect) assay from Abbott Diagnostics. cTn concentrations were investigated both in a reference population and in a cohort of marathon runners. We included the current commercially available cTnT assay (fourth generation) in the study for comparison.

\section{Methods}

\section{Reference population}

The reference population consisted of 546 apparently healthy persons from a health-check program at our hospital, and all of the individuals provided informed consent. To rule out individuals with cardiac syndromes, we included individuals in the study only when the following cardiac biomarker concentrations were all available: creatine kinase isoenzyme $\mathrm{MB}, \mathrm{N}$-terminal pro-B-type natriuretic peptide, cTnT measured with the hs-cTnT assay, and cTnI measured with the cTnIArchitect assay (details of the cTn measurements are described below). Consequently, we excluded 45 individuals from the reference population. We also excluded 22 individuals because the concentration of one of these 4 biomarkers exceeded the mean +3 SDs: creatine kinase isoenzyme MB mass (male cutoff, $>10$ $\mu \mathrm{g} / \mathrm{L}$; female cutoff, $>7.9 \mu \mathrm{g} / \mathrm{L}$; maximum, $13.37 \mu \mathrm{g} / \mathrm{L}$ ) in 10 individuals, $\mathrm{N}$-terminal pro-B-type natriuretic peptide concentration (cutoff, $>41 \mathrm{pmol} / \mathrm{L}$; maximum, 166 $\mathrm{pmol} / \mathrm{L}$ ) in 8 individuals, and cTn concentration (cTnT maximum, $0.134 \mu \mathrm{g} / \mathrm{L} ; \mathrm{cTnI}$ maximum, $0.217 \mu \mathrm{g} / \mathrm{L}$ ) in 4 individuals. 


\section{Marathon population}

Of the 836 runners who participated in the 2007 Maas Marathon $(42.2 \mathrm{~km}), 85$ runners were enrolled in the present study. This study was approved by the ethics committee (Maastricht University Medical Center, the Netherlands), and all participants signed informed consent forms. The maximum temperature on the day of the marathon was $23.4^{\circ} \mathrm{C}$ with a south wind $<14 \mathrm{~m} / \mathrm{s}$. We collected serum samples $0-2 \mathrm{~h}$ before the race, $<1 \mathrm{~h}$ after the race, and on the day after the race in a subgroup of 23 runners whom we selected for logistical reasons.

\section{Biomarker measurement}

The serum samples were clotted, centrifuged, and stored at $-80^{\circ} \mathrm{C}$ until analysis. cTnI was measured with the Architect i2000SR (Abbott Diagnostics), with an LOD of $0.009 \mu \mathrm{g} / \mathrm{L}$, a CV of $\leq 10 \%$ at $0.032 \mu \mathrm{g} / \mathrm{L}$, and the $99^{\text {th }}$ percentile cutoff at 0.012 $\mu \mathrm{g} / \mathrm{L}$, as provided by the manufacturer. We measured cTnT on the Elecsys 2010 instrument (Roche Diagnostics) with the current commercially available cTnT immunoassay (fourth generation), with an LOD of $<0.01 \mu \mathrm{g} / \mathrm{L}$, a CV $\leq 10 \%$ at 0.03 $\mu \mathrm{g} / \mathrm{L}$, and a 99th percentile cutoff at $<0.01 \mu \mathrm{g} / \mathrm{L}$. cTnT was also measured with the pre-commercial hs-cTnT assay. Complete validation of the hs-cTnT assay (same lot number) was performed in the research and development department of Roche Diagnostics. Intra-assay CVs were $5.7 \%$ and $0.5 \%$ at $0.022 \mu \mathrm{g} / \mathrm{L}$ and $2.98 \mu \mathrm{g} / \mathrm{L}$, respectively; inter-assay CVs were $3.0 \%$ and $1.4 \%$ at $0.021 \mu \mathrm{g} / \mathrm{L}$ and $3.03 \mu \mathrm{g} / \mathrm{L}$, respectively. The linearity of the hs-cTnT assay was evaluated by serial dilution, from 1 part serum plus 9 parts diluent to 9 parts serum plus 1 part diluent (initial cTnT concentration in serum, $9.5 \mu \mathrm{g} / \mathrm{L}$; Diluent Universal, Roche Diagnostics). The measured cTnT concentrations deviated from the expected concentrations by factors of 0.99 to 1.05. A comparison of the current cTnT assay and the hs-cTnT assay (cTnT up to $8 \mu \mathrm{g} / \mathrm{L}, \mathrm{n}=160$ ) yielded the following regression equation: $\mathrm{y}=$ $0.996 x+0.003 \mu \mathrm{g} / \mathrm{L}$, where $\mathrm{x}$ represents results obtained for the current commercial cTnT assay and $y$ represents results for the hs-cTnT assay $[r=0.9926$; 95th percentile of the residual distribution from the median $=0.331$ (Passing-Bablok regression analysis)]. We also measured creatine kinase and albumin concentrations with the Synchron LX 20 instrument (Beckman Coulter). 


\section{Statistical analysis}

Data were analyzed with the Statistical Package for Social Sciences, Version 13.0 for Windows (SPSS). A nonparametric approach was used to calculate the upper reference limits (97.5 th and 99th percentiles), and the Kolmogorov-Smirnov test was used to evaluate whether biomarker data deviated from a gaussian distribution. The LOD was defined by the sum of the mean of 10 measurements of cTn-negative serum +3 SD. For variables with a gaussian distribution, we used the pairedsamples t-test to evaluate differences between pre- and post-exercise samples and used the independent-samples t-test to test gender differences. Multiple regression analysis was used to evaluate possible associations of gender, age, body mass index, and experience (i.e., number of prior completed marathons) with postmarathon cTn concentration. We log-transformed the data with non-gaussian distributions and analyzed the data as described above if the transformed data approximated a gaussian distribution. For variables with a non-gaussian distribution, we analyzed the original data with the nonparametric Wilcoxon signed rank test and the Mann-Whitney U-test. For statistical calculations, cTnT concentrations less than the LOD were set equal to the LOD. Unless otherwise stated, the threshold for statistical significance was set at a P level of 0.05 .

\section{Results}

We used the NCCLS (now CLSI) EP5 guideline to establish precision profiles for the hs-cTnT and cTnI-Architect assays. As shown in Figure 1, the assay profiles produced $10 \%-C V$ cutoff concentrations at $0.009 \mu \mathrm{g} / \mathrm{L}$ and $0.032 \mu \mathrm{g} / \mathrm{L}$, respectively. We used 10 measurements of cTn-negative serum (mean +3 SDs) to establish LODs for the hs-cTnT and cTnI-Architect assays. The LOD was $<0.001 \mu \mathrm{g} / \mathrm{L}$ for the hs-cTnT assay and $0.009 \mu \mathrm{g} / \mathrm{L}$ for the cTnI-Architect assay. 
A)

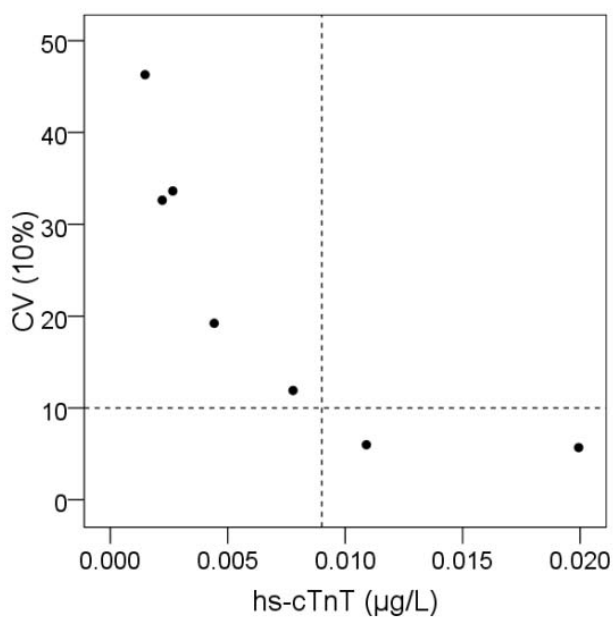

B)

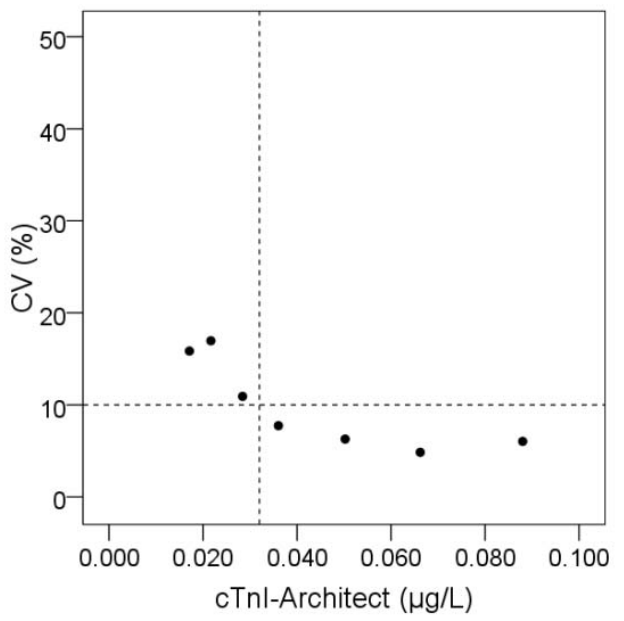

Figure 1. Precision profiles using a panel of serum samples as established for (A) the hs-cTnT assay with CV=10\% at $0.009 \mu \mathrm{g} / \mathrm{L}$ and for (B) the cTnI-Architect assay with $\mathrm{CV}=10 \%$ at $0.032 \mu \mathrm{g} / \mathrm{L}$.

The left side of figure 2 shows the cTn concentrations obtained for the reference population. With the cTnI-Architect assay, almost all measurements (97\%) were below the LOD. In contrast, the hs-cTnT assay yielded measurable concentrations for most of the samples in the reference population. For the cTnI-Architect assay, the $99^{\text {th }}$-percentile value $(0.013 \mu \mathrm{g} / \mathrm{L})$ was less than the $10 \%-\mathrm{CV}$ value. In contrast, the hs-cTnT assay had a CV of $<10 \%$ at the $99^{\text {th }}$-percentile value $(0.016 \mu \mathrm{g} / \mathrm{L})$. The current commercially available cTnT assay (fourth generation) produced values that were all below the LOD $(<0.01 \mu \mathrm{g} / \mathrm{L})$. Finally, analysis of the hs-cTnT data revealed cTn reference values that were higher for males than for females $(\mathrm{P}<$ 0.001; Table 1). Table 2 summarizes the baseline characteristics of the marathon population (85 runners). These data are comparable with those of the total marathon population of 836 runners ( $88 \%$ men; mean age, 45 years; mean running time, $3.76 \mathrm{~h}$ ). The participants in our study seem to be highly experienced runners. Fortyfour percent had previously completed 1-10 marathons, and 36\% had completed $>10$ marathons. 
Table 1. cTn reference values as measured with the hs-cTnT and cTnI-Architect assays. ${ }^{a}$

\begin{tabular}{|c|c|c|}
\hline Study population & $H s-c T n T$ assay $\mu g / L$ & cTnI-architect assay $\mu g / L^{L}$ \\
\hline \multicolumn{3}{|l|}{ Total $n=479$} \\
\hline Mean & 0.004 & 0.001 \\
\hline Median & 0.004 & $<0.001$ \\
\hline $97.5^{\text {th }}$ percentile & 0.011 & 0.008 \\
\hline $99^{\text {th }}$ percentile & 0.016 & 0.013 \\
\hline \multicolumn{3}{|l|}{ Females $n=215$} \\
\hline mean & 0.003 & 0.001 \\
\hline Median & 0.003 & 0.000 \\
\hline $97.5^{\text {th }}$ percentile & 0.007 & 0.007 \\
\hline $99^{\text {th }}$ percentile & 0.008 & 0.012 \\
\hline \multicolumn{3}{|l|}{ Males $n=264$} \\
\hline Mean & 0.005 & 0.001 \\
\hline Median & 0.005 & $<0.001$ \\
\hline $97.5^{\text {th }}$ percentile & 0.014 & 0.008 \\
\hline $99^{\text {th }}$ percentile & 0.018 & 0.013 \\
\hline
\end{tabular}

a Data for both assays were not normally distributed $(\mathrm{P}<0.001)$, including after log transformation. Differences between males and females in mean cTn concentration: hs-cTnT assay, $\mathrm{P}<0.001$; cTnI-Architect assay, $\mathrm{P}=0.788$.

b Ninety-seven percent of the measurements were below the LOD $(0.009 \mu \mathrm{g} / \mathrm{L})$.

Table 2. Baseline characteristics of the reference and marathon study population.

\begin{tabular}{|c|c|c|c|c|c|}
\hline & Age $e^{a}$ & Weight $^{a}$ & Height $^{a}$ & $\begin{array}{l}\text { Marathons } \\
\text { completed }^{b}\end{array}$ & Running time \\
\hline & years & $\mathrm{kg}$ & $m$ & $n$ & $h$ \\
\hline \multicolumn{6}{|l|}{ Marathon runners } \\
\hline Total $\mathrm{n}=85$ & $47(27-67)$ & $70(53-89)$ & $1.77(1.58-1.92)$ & $7(191)$ & $3.80(2.90-5.00)$ \\
\hline Females $n=15$ & $46(27-60)$ & $57(50-65)$ & $1.66(1.58-1.75)$ & $5(57)^{c}$ & $4.18(3.49-5.34)$ \\
\hline Males $n=70$ & $47(30-68)$ & $73(61-90)$ & $1.79(1.68-1.93)$ & $8(255)$ & $3.71(2.87-4.69)$ \\
\hline \multicolumn{6}{|l|}{ Reference population } \\
\hline Total $\mathrm{n}=479$ & $51(26-71)$ & & & & \\
\hline Females $n=215$ & $49(26-68)$ & & & & \\
\hline
\end{tabular}

a The data are consistent with a gaussian distribution and are presented as the mean $(95 \% \mathrm{CI})$.

${ }^{\mathrm{b}}$ The data did not fit a gaussian distribution and are presented as the median (97.5th percentile).

c The 92nd percentile is shown because of the small sample size $(n=15)$.

Figure 2 also shows that only the hs-cTnT and cTnI-Architect assays were able to measure prerace cTn concentrations. All prerace concentrations obtained with the current commercially available cTnT assay were below the assay's LOD. 


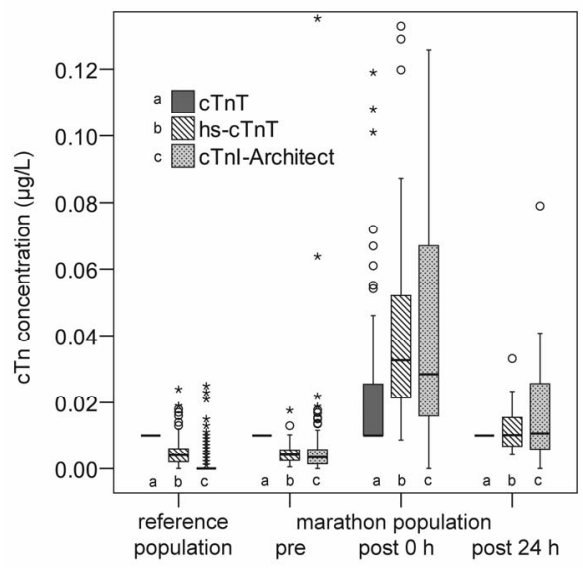

Figure 2. cTn concentrations in the reference and marathon study populations as measured with the current commercially available cTnT assay, the hs-cTnT assay, and the cTnI-Architect assay. Boxes represent the interquartile range (IQR), whiskers represent $1.5 \times$ the IQR values, and horizontal lines represent medians. Extreme values (o) represent values between 1.5x $\mathrm{IQR}$ and $3 \times$ IQR; outliers $\left(^{*}\right)$ represent values $>3 \times$ IQR.

Table 3 shows that prerace concentrations obtained with the hs-cTnT assay were within the reference interval $(\mathrm{P}=0.282)$. Prerace concentrations were significantly higher than the reference values $(\mathrm{P}<0.001)$ when the cTnI-Architect assay was used; however, pre-exercise concentrations obtained with the cTnI-Architect assay should be considered with care, because $82 \%$ were below the LOD of the assay $(<0.009 \mu \mathrm{g} / \mathrm{L})$.

Immediately after the marathon, all runners in the study showed an approximately 10-fold increase in cTnT and cTnI concentrations in the hs-cTnT and cTnI-Architect assays (Table 3). Albumin concentrations increased only slightly after the marathon; hence, we did not correct cTn concentrations for the effect of dehydration. The hs-cTnT assay showed that the cTnT concentration had increased to above the $99^{\text {th }}$ percentile $(0.016 \mu \mathrm{g} / \mathrm{L})$ in almost all of the runners $(86 \%)$. In contrast, only about half of the runners (45\%) were above the $99^{\text {th }}$-percentile value $(0.01 \mu \mathrm{g} / \mathrm{L})$ when the current commercially available cTnT assay was used. Results obtained with the hs-cTnT assay were highly correlated with values obtained with the current cTnT assay (Spearman rank correlation coefficient 0.955, for values above the $10 \%-C V$ cutoff concentration; $\mathrm{P}<0.001)$. 
Table 3. Measurement statistics for the marathon study population for serum samples taken before, immediately after $(0 \mathrm{~h})$, and the day after $(24 \mathrm{~h})$ the race.

\begin{tabular}{|c|c|c|c|c|c|}
\hline & $\begin{array}{l}\text { Fourth-generation } \\
\text { cTnT assay, } \mu g / L\end{array}$ & $\begin{array}{c}\text { Hs-cTnT } \\
\text { assay, } \mu g / L\end{array}$ & $\begin{array}{c}\text { cTnI-architect } \\
\text { assay, } \mu g / L\end{array}$ & $\begin{array}{l}C K \\
U / L\end{array}$ & $\begin{array}{c}\text { Albumin } \\
\mathrm{g} / \mathrm{L}\end{array}$ \\
\hline \multicolumn{6}{|l|}{ Pre-race $(\mathrm{n}=85)$} \\
\hline Mean & $<\mathrm{LOD}$ & 0.004 & 0.007 & 141 & 43.8 \\
\hline median & $<\mathrm{LOD}$ & 0.004 & 0.003 & 117 & 43.8 \\
\hline $97.5^{\text {th }}$ percentile & $<\mathrm{LOD}$ & 0.010 & 0.022 & 293 & 48.0 \\
\hline Normality test, $\mathrm{P}$ & $<0.001$ & $0.200^{\mathrm{a}, \mathrm{b}}$ & $<0.001$ & $0.200^{\mathrm{a}, \mathrm{b}}$ & $0.200^{\mathrm{b}}$ \\
\hline Male/female difference, $\mathrm{P}$ & 1.000 & $0.008^{\mathrm{a}}$ & 0.021 & $0.002^{\mathrm{a}}$ & 0.136 \\
\hline \multicolumn{6}{|l|}{ Postrace samples, 0 h (n=85) } \\
\hline Mean & 0.026 & 0.042 & 0.057 & 508 & 47.8 \\
\hline Median & $<\mathrm{LOD}$ & 0.033 & 0.029 & 378 & 48 \\
\hline $97.5^{\text {th }}$ percentile & 0.119 & 0.133 & 0.231 & 2249 & 52.7 \\
\hline Normality test, $\mathrm{P}$ & $<0.001$ & $0.200^{\mathrm{a}, \mathrm{b}}$ & $0.200^{\mathrm{a}, \mathrm{b}}$ & $0.021^{\mathrm{a}}$ & $0.200^{\mathrm{b}}$ \\
\hline $\begin{array}{l}\text { Prerace/postrace } \\
\text { difference, } \mathrm{P}\end{array}$ & $<0.001$ & $<0.001^{\text {a }}$ & $<0.001^{\mathrm{a}}$ & $<0.001^{\text {a }}$ & $<0.001$ \\
\hline Male/female difference, $\mathrm{P}$ & 0.411 & $0.451^{\mathrm{a}}$ & $0.156^{\mathrm{a}}$ & $0.793^{\mathrm{a}}$ & 0.031 \\
\hline \multicolumn{6}{|l|}{ Postrace samples, 24 h (n=23) } \\
\hline Mean & $<\mathrm{LOD}$ & 0.012 & 0.031 & 2183 & 42.6 \\
\hline Median & $<\mathrm{LOD}$ & 0.010 & 0.011 & 1458 & 42.8 \\
\hline $97.5^{\text {th }}$ percentile & $<\mathrm{LOD}$ & $0.023^{c}$ & $0.145^{c}$ & $6240^{c}$ & $47.0^{c}$ \\
\hline Normality test, $\mathrm{P}$ & $<0.001$ & $0.200^{\mathrm{a}, \mathrm{b}}$ & $0.200^{\mathrm{a}, \mathrm{b}}$ & $0.200^{\mathrm{a}, \mathrm{b}}$ & $0.200^{\mathrm{a}}$ \\
\hline $\begin{array}{l}\text { Prerace/postrace } \\
\text { difference, } \mathrm{P}\end{array}$ & \multicolumn{4}{|c|}{ difference, $\mathrm{P}$} & 0.359 \\
\hline Male/female difference, $\mathrm{P}$ & 1.000 & $0.214^{\mathrm{a}}$ & $0.967^{\mathrm{a}}$ & $0.596^{\mathrm{a}}$ & 0.170 \\
\hline Data normalized by & og-transformation $\mathrm{p}$ & r to testing & & & \\
\hline Highest possible $\mathrm{P}$ - & lue given by the Kol & gorov-Smirr & test of normality & & \\
\hline Because of the smal & ample size $(n=23)$, & lues for the 9 & ercentile are sh & & \\
\hline
\end{tabular}

The cTnI-Architect assay yielded cTnI concentrations that were increased to greater than the $99^{\text {th }}$ percentile in $81 \%$ of the runners. This percentage appeared comparable to that of the hs-cTnT assay; however, the $10 \%-\mathrm{CV}$ cutoff $(0.032 \mu \mathrm{g} / \mathrm{L})$ was exceeded in only $47 \%$ of the runners when the cTnI-Architect assay was used. For the hs-cTnT assay, nearly all of the post-exercise concentrations (98\%) were greater than the $10 \%-\mathrm{CV}$ concentration $(0.009 \mu \mathrm{g} / \mathrm{L})$.

Multiple regression analysis (Table 4) revealed running experience (the number of previously completed marathons) and age to be significant predictors of postmarathon cTn concentration as detected with the hs-cTnT assay (experience, $\mathrm{P}=$ 0.005; age, $\mathrm{P}=0.017$ ) and the cTnI-Architect assay (experience, $\mathrm{P}=0.001$; age, $\mathrm{P}=$ 0.008). Indeed, a comparison of the 2 outer quartiles of these cTn results showed that the runners with the lowest cTn concentrations had significantly more experience in marathon running than those with the highest cTn concentrations 
(hs-cTnT assay, $\mathrm{P}=0.005$; cTnI-Architect assay, $\mathrm{P}=0.036$ ). With respect to age, we found no significant difference between the 2 outer cTn quartiles for either the hscTnT assay $(P=0.254)$ or the cTnI-Architect assay $(P=0.689)$. We also noted no significant interaction between experience and age in the regression model (hscTnT assay, $\mathrm{P}=0.542$; cTnI-Architect assay, $\mathrm{P}=0.696)$. Furthermore, gender and body mass index showed no significant association with post-exercise cTn concentration (Table 4). A regression analysis of the change in cTn concentration (post-exercise concentration minus pre-exercise concentration) showed experience and age to be significant predictors of the change in cTn concentration (Table 5). Finally, in contrast to pre-exercise cTn concentrations, post-exercise concentrations appeared to be higher in women than in men, but this gender difference was not statistically significant (Table 3).

The day after the marathon, cTn concentrations returned to below the LOD when the current commercially available cTnT assay was used (Figure 2). When hs-cTnT and cTnI-Architect assays were used, cTn concentrations measured 1 day after the race remained significantly increased compared with pre-race cTn concentrations ( $\mathrm{P}<0.001$ for both the hs-cTnT and cTnI-Architect assays). The cTn concentration was still greater than the $99^{\text {th }}$ percentile value in $17 \%$ of the runners measured with the hs-cTnT assay and in $43 \%$ of the runners measured with the cTnI-Architect assay. The selected group of 23 runners who were studied the day after the marathon was compared with the total marathon study population (85 runners). The 2 groups showed no significant differences in pre-race and post-race cTn concentrations $(\mathrm{P}>0.1)$ measured with any of the cTn assays used in this study. 
Table 4. Multiple linear regression models for log-transformed cTn concentrations directly after the race as measured with the (A) hs-cTnT and (B) cTnI-Architect assay.

A)

\begin{tabular}{|c|c|c|c|c|c|c|}
\hline & $\log (h s-c T n T)$ & $B^{a}$ & $S E^{b}$ & p-value & Power & $R^{c}$ \\
\hline \multirow[t]{3}{*}{ Model 1} & & & & 0.061 & 0.469 & 0.242 \\
\hline & Intercept & 1.63 & 0.07 & $<0.001$ & & \\
\hline & Log (experience) & -0.11 & 0.06 & 0.061 & & \\
\hline \multirow[t]{4}{*}{ Model 2} & & & & 0.010 & 0.792 & 0.383 \\
\hline & Intercept & 1.20 & 0.19 & $<0.001$ & & \\
\hline & Log (experience) & -0.19 & 0.06 & 0.005 & & \\
\hline & Age & 0.01 & 0.00 & 0.017 & & \\
\hline \multirow[t]{5}{*}{ Model 3} & & & & 0.025 & 0.730 & 0.387 \\
\hline & Intercept & 1.21 & 0.19 & $<0.001$ & & \\
\hline & Log (experience) & -0.19 & 0.06 & 0.005 & & \\
\hline & Age & 0.01 & 0.00 & 0.021 & & \\
\hline & Gender & 0.04 & 0.09 & 0.657 & & \\
\hline \multirow[t]{6}{*}{ Model 4} & & & & 0.055 & 0.669 & 0.387 \\
\hline & Intercept & 1.30 & 0.56 & 0.025 & & \\
\hline & Log (experience) & -0.19 & 0.06 & 0.005 & & \\
\hline & Age & 0.01 & 0.00 & 0.024 & & \\
\hline & Gender & -0.05 & 0.11 & 0.641 & & \\
\hline & BMI & 0.00 & 0.02 & 0.871 & & \\
\hline
\end{tabular}

B)

\begin{tabular}{|c|c|c|c|c|c|c|}
\hline & $\log (c T n I$ architect $)$ & $B^{a}$ & $S E^{b}$ & $p$-value & Power & $\boldsymbol{R}^{c}$ \\
\hline \multirow[t]{3}{*}{ Model 1} & & & & 0.023 & 0.629 & 0.290 \\
\hline & Intercept & 1.74 & 0.10 & $<0.001$ & & \\
\hline & Log (experience) & -0.20 & 0.09 & 0.023 & & \\
\hline \multirow[t]{4}{*}{ Model 2} & & & & 0.002 & 0.907 & 0.437 \\
\hline & Intercept & 1.01 & 0.28 & 0.001 & & \\
\hline & Log (experience) & -0.33 & 0.09 & 0.001 & & \\
\hline & Age & 0.02 & 0.01 & 0.008 & & \\
\hline \multirow[t]{5}{*}{ Model 3} & & & & 0.006 & 0.864 & 0.440 \\
\hline & Intercept & 0.98 & 0.29 & 0.001 & & \\
\hline & Log (experience) & -0.33 & 0.10 & 0.001 & & \\
\hline & Age & 0.02 & 0.01 & 0.007 & & \\
\hline & Gender & 0.07 & 0.15 & 0.657 & & \\
\hline \multirow[t]{6}{*}{ Model 4} & & & & 0.015 & 0.816 & 0.440 \\
\hline & Intercept & 1.12 & 0.82 & 0.178 & & \\
\hline & Log (experience) & -0.33 & 0.10 & 0.001 & & \\
\hline & Age & 0.02 & 0.01 & 0.009 & & \\
\hline & Gender & 0.05 & 0.16 & 0.746 & & \\
\hline & BMI & -0.01 & 0.03 & 0.857 & & \\
\hline
\end{tabular}

a unstandardized coefficient in regression equation

b Standard Error

' Pearson's correlation coefficient 


\section{Chapter 4}

Table 5: Multiple linear regression models for log-transformed delta $(\Delta)$ (post- minus pre-race) cTn concentrations as measured with the (A) hs-cTnT and (B) cTnI-Architect assay.

A)

\begin{tabular}{|c|c|c|c|c|c|c|}
\hline & $\log (\Delta h s-c T n T)$ & $B^{a}$ & $S E^{b}$ & $p$-value & Power & $R^{c}$ \\
\hline \multirow[t]{3}{*}{ Model 1} & & & & 0.048 & 0.510 & 0.254 \\
\hline & Intercept & -1.42 & 0.08 & $<0.001$ & & \\
\hline & Log (experience) & -0.13 & 0.07 & 0.048 & & \\
\hline \multirow[t]{4}{*}{ Model 2} & & & & 0.031 & 0.656 & 0.336 \\
\hline & Intercept & -1.78 & 0.22 & $<0.001$ & & \\
\hline & Log (experience) & -0.19 & 0.07 & 0.010 & & \\
\hline & Age & 0.01 & 0.01 & 0.081 & & \\
\hline \multirow[t]{5}{*}{ Model 3} & & & & 0.070 & 0.587 & 0.340 \\
\hline & Intercept & -1.77 & 0.22 & $<0.001$ & & \\
\hline & Log (experience) & -0.19 & 0.07 & 0.011 & & \\
\hline & Age & 0.01 & 0.01 & 0.091 & & \\
\hline & Gender & -0.05 & 0.11 & 0.673 & & \\
\hline \multirow[t]{6}{*}{ Model 4} & & & & 0.133 & 0.526 & 0.341 \\
\hline & Intercept & -1.64 & 0.65 & 0.014 & & \\
\hline & Log (experience) & -0.19 & 0.07 & 0.011 & & \\
\hline & Age & 0.01 & 0.01 & 0.103 & & \\
\hline & Gender & -0.06 & 0.12 & 0.636 & & \\
\hline & BMI & -0.01 & 0.03 & 0.826 & & \\
\hline
\end{tabular}

B)

\begin{tabular}{|c|c|c|c|c|c|c|}
\hline & $\log (\Delta c \operatorname{TnI}$ architect $)$ & $B^{a}$ & $S E^{b}$ & p-value & Power & $\boldsymbol{R}^{c}$ \\
\hline \multirow[t]{3}{*}{ Model 1} & & & & 0.081 & 0.416 & 0.227 \\
\hline & Intercept & -1.38 & 0.12 & $<0.001$ & & \\
\hline & Log (experience) & -0.19 & 0.10 & 0.081 & & \\
\hline \multirow[t]{4}{*}{ Model 2} & & & & 0.013 & 0.765 & 0.376 \\
\hline & Intercept & -2.17 & 0.34 & $<0.001$ & & \\
\hline & Log (experience) & -0.32 & 0.12 & 0.007 & & \\
\hline & Age & 0.02 & 0.01 & 0.018 & & \\
\hline \multirow[t]{5}{*}{ Model 3} & & & & 0.024 & 0.738 & 0.393 \\
\hline & Intercept & -2.24 & 0.35 & $<0.001$ & & \\
\hline & Log (experience) & -0.34 & 0.02 & 0.005 & & \\
\hline & Age & 0.02 & 0.01 & 0.013 & & \\
\hline & Gender & 0.17 & 0.18 & 0.356 & & \\
\hline \multirow[t]{6}{*}{ Model 4} & & & & 0.050 & 0.682 & 0.395 \\
\hline & Intercept & -2.56 & 1.00 & 0.014 & & \\
\hline & Log (experience) & -0.33 & 0.12 & 0.006 & & \\
\hline & Age & 0.02 & 0.01 & 0.013 & & \\
\hline & Gender & 0.19 & 0.20 & 0.331 & & \\
\hline & BMI & 0.01 & 0.04 & 0.734 & & \\
\hline
\end{tabular}

a unstandardized coefficient in regression equation

b Standard Error

c Pearson's correlation coefficient 


\section{Discussion}

cTnT and cTnI immunoassays that have lower LODs, such as the hs-cTnT and cTnI- Architect assays, are better able to delineate the upper reference limits for cTn because of analytical improvements made in the lower portion of the measurement interval $(<0.01 \mu \mathrm{g} / \mathrm{L})$. The hs-cTnT assay was the only assay tested in this study that achieved sufficient precision, ${ }^{14,15}$ because the $10 \%-\mathrm{CV}$ cutoff concentration $(0.009 \mu \mathrm{g} / \mathrm{L})$ was lower than the $99^{\text {th }}$ percentile value of the reference population $(0.016 \mu \mathrm{g} / \mathrm{L}$, diagnostic cutoff). The hs-cTnT assay had the lowest LOD in this study and in this respect appears superior to the other cTn assays currently available. ${ }^{20}$ Our analytical results for the hs-cTnT assay are in agreement with those of Latini et al. ${ }^{11}$ and Kurz et al., ${ }^{21}$ the only other reports to have described the use of this pre-commercial assay. Latini et al. obtained an LOD of $0.001 \mu \mathrm{g} / \mathrm{L}$, an interassay $\mathrm{CV}$ of $5 \%$ at $0.01 \mu \mathrm{g} / \mathrm{L}$, and an inter-assay $\mathrm{CV}$ of $8 \%$. In the reference population ( $\mathrm{n}=1061$, with a concurrent $\mathrm{N}$-terminal pro-B-type natriuretic peptide concentration of $<125 \mathrm{ng} / \mathrm{L}$ ), these investigators obtained a $99^{\text {th }}$ percentile $\mathrm{cTnT}$ cutoff value of $0.012 \mu \mathrm{g} / \mathrm{L}$. We obtained significantly higher cTnT concentrations in males than in females with the hs-cTnT assay, a difference that has not been reported previously. ${ }^{19,} 22$ Given that the mean heart size is larger for males than for females, ${ }^{23,} 24$ it is reasonable to expect cTn reference values of males and females to differ. More accurate methods are required to study this possible gender difference, because the $10 \%-\mathrm{CV}$ cutoff value of the hs-cTnT assay $(0.009 \mu \mathrm{g} / \mathrm{L})$ was higher than the mean and median cTnT concentrations in the reference population studied (males, $0.005 \mu \mathrm{g} / \mathrm{L}$; females, $0.003 \mu \mathrm{g} / \mathrm{L}$ ). In addition, it is noteworthy that the $99^{\text {th }}$ percentile value of the reference population is slightly higher with the hscTnT assay $(0.016 \mu \mathrm{g} / \mathrm{L})$ than with the current commercially available assay $(0.01$ $\mu \mathrm{g} / \mathrm{L}$ ), but measurements with the current assay are not reliable for concentrations $<0.03 \mu \mathrm{g} / \mathrm{L}$ (i.e., with $\mathrm{CVs}>10 \%$ ). With the cTnI-Architect assay, we did not obtain sufficient precision in the lower part of the measurement interval (a CV $>10 \%$ at the $99^{\text {th }}$ percentile value of the reference population). Recently, Tate et al. reported a comparison study of $9 \mathrm{cTn}$ assays. ${ }^{25}$ Individuals were excluded from the reference population in case of diabetes mellitus, hypertension, cardiac disease, hyperlipidemia, and patients taking cardiac medications. The $99^{\text {th }}$ percentile value 
in this reference population $(\mathrm{n}=111)$ with the cTnI-Architect assay was $0.021 \mu \mathrm{g} / \mathrm{L}$, which is even higher than the cutoff we reported $(0.013 \mu \mathrm{g} / \mathrm{L})$. In addition, Wu et al. recently showed that $\mathrm{c} T n \mathrm{I}$ concentrations assayed in a reference population with a prototype assay based on single-photon fluorescence detection fit a gaussian distribution. ${ }^{26,27}$ The introduction of more sensitive and accurate cTn assays affects the number of AMI patients who are detected..$^{28}$ Serial cTn testing with the use of highly sensitive assays will be necessary to determine the clinical significance of cTn concentrations at the lower end of the measurement interval. ${ }^{29}$

In most studies that have investigated prolonged exercise, cTn concentrations became detectable immediately after exercise. ${ }^{10}, 30,31$ Pre-exercise concentrations were below the LOD, ${ }^{16-18}$ as was seen in the present study for the current commercially available cTnT assay. In addition, assay imprecision was too high to differentiate pre-exercise values from noise, ${ }^{16-18}$ an observation that held true for the cTnI-Architect assay in our study. The hs-cTnT assay showed increases in cTnT in almost all of the marathon runners (86\%). In contrast, a meta-analysis of 26 studies (1120 individuals) that used second- and third-generation cTnT assays showed cTnT increases in only $47 \%$ of the individuals. ${ }^{32}$ When a third generation cTnT assay was used, about half of the runners (59\%) also showed increased cTnT concentrations..$^{10}$ It is still questionable whether cardiovascular insufficiency is the underlying mechanism of collapse during or after prolonged exercise. With a fourth-generation cTnT assay, Siegel et al. reported that only $18 \%$ of collapsed marathon runners $(\mathrm{n}=99)$ showed increased cTn concentrations. ${ }^{33}$

The cTnI-Architect assay produced a broader cTn distribution than the hs-cTnT assay, both immediately after the race and a day later. This finding might be explained by the higher imprecision of the cTnI-Architect assay. Nevertheless, both the hs-cTnT and cTnI-Architect assays showed that $\mathrm{cTnT}$ and cTnI concentrations remained significantly increased the day after the marathon. This finding is in contrast with the results obtained with the majority of cTn assays, in which cTn seems to return to baseline concentrations within a day.

The cTn concentrations in runners after a marathon were higher than the cutoff used for diagnosing AMI.14, 15 The concentration difference, however, was minimal and the increases occurred in the absence of any clinical symptoms. Two opposing theories attempt to explain the link between exercise-induced cTn release and 
(acute) cardiac events. ${ }^{34}$ First, the reversibility concept proposes that exercise increases the number of radicals and thereby membrane permeability, causing cTn leakage from the cytosolic cellular pool.35, 36 This release has been suggested to be relatively fast and may correspond to the first cTn peak seen in AMI patients $(<1$ day). ${ }^{30,} 37,38$ Subsequently, however, there would be an influx and efflux of cytoplasmic constituents up to toxic levels. The second theory, the irreversibility concept, suggests that the cTn released after prolonged exercise is due to the breakdown of myocytes. This release would require the dissociation of cTn from the cTn complex (on actin molecules) and is thought to be much slower (>1 day). It therefore could correspond to the later cTn release that is seen as a second peak in AMI patients. ${ }^{30,37,38}$ Whether prolonged exercise has any long-term consequences remains to be clarified. To address this issue, Hessel et al. studied cTnI release from cultures of rat cardiomyocytes and demonstrated the release of intact cTnI from viable cardiomyocytes, ${ }^{39}$ which would imply that it is reversible cell damage that takes place after prolonged exercise. Further research is required to reveal whether troponin release after AMI is similar to the release occurring after prolonged exercise, both from a structural and from a kinetic point of view.

In the largest marathon population studied thus far (482 runners), less marathon experience and a higher age appeared to be associated with increases in cTn, whereas race duration and the presence of traditional cardiovascular risk factors were not. ${ }^{8}$ Neilan et al. used both echocardiography and serum biomarkers to study non-elite marathon runners specifically ${ }^{31}$ and found that cTnT concentrations were significantly higher in runners who trained $\leq 56 \mathrm{~km} /$ week than in runners who trained $>72 \mathrm{~km} /$ week. In a meta-analysis of 1120 individuals, Shave et al. ${ }^{32}$ found exercise duration to affect post-exercise cTn concentration but found the effect of age to be non-significant. When we used more sensitive assays, we also found a significant negative correlation between post-marathon cTn concentration and experience and found a non-significant positive relationship with age.

The clinical impact of exercise-induced increases in cTn concentration has not yet been fully clarified. Herrmann et al. advised that until the phenomenon is better understood, affected athletes should undergo further cardiologic investigation, including a stress test..$^{40}$ Whyte et al. suggested that serial measurements should be made after a marathon to evaluate a patient for an AMI. ${ }^{41}$ In the present study, the 
use of cTn assays with lower LODs showed $86 \%$ of the athletes to have increased cTnT concentrations after a marathon and $81 \%$ to have increased cTnI concentrations. There seems to be no rationale for examining all athletes with positive cTn concentrations in the absence of clinical symptoms. Further research is required to investigate whether a diagnostic cTn cutoff higher than the 99th percentile value is more realistic for well-trained athletes.

\section{References}

1. Thompson PD, Franklin BA, Balady GJ, Blair SN, Corrado D, Estes NA, 3rd, Fulton JE, Gordon NF, Haskell WL, Link MS, Maron BJ, Mittleman MA, Pelliccia A, Wenger NK, Willich SN, Costa F. Exercise and acute cardiovascular events placing the risks into perspective: A scientific statement from the american heart association council on nutrition, physical activity, and metabolism and the council on clinical cardiology. Circulation. 2007;115:2358-2368

2. Tunstall Pedoe DS. Marathon cardiac deaths : The london experience. Sports Med. 2007;37:448-450

3. Roberts WO, Maron BJ. Evidence for decreasing occurrence of sudden cardiac death associated with the marathon. J Am Coll Cardiol. 2005;46:1373-1374

4. Redelmeier DA, Greenwald JA. Competing risks of mortality with marathons: Retrospective analysis. Bmj. 2007;335:1275-1277

5. Scharhag J, Herrmann M, Urhausen A, Haschke M, Herrmann W, Kindermann W. Independent elevations of n-terminal pro-brain natriuretic peptide and cardiac troponins in endurance athletes after prolonged strenuous exercise. Am Heart J. 2005;150:1128-1134

6. La Gerche A, Connelly KA, Mooney DJ, Macisaac AI, Prior DL. Biochemical and functional abnormalities of left and right ventricular function following ultra-endurance exercise. Heart. 2007;94:860-866

7. Kratz A, Lewandrowski KB, Siegel AJ, Chun KY, Flood JG, Van Cott EM, Lee-Lewandrowski E. Effect of marathon running on hematologic and biochemical laboratory parameters, including cardiac markers. Am J Clin Pathol. 2002;118:856-863

8. Fortescue EB, Shin AY, Greenes DS, Mannix RC, Agarwal S, Feldman BJ, Shah MI, Rifai N, Landzberg MJ, Newburger JW, Almond CS. Cardiac troponin increases among runners in the boston marathon. Ann Emerg Med. 2007;49:137-143, 143 e131

9. Leers MP, Schepers R, Baumgarten R. Effects of a long-distance run on cardiac markers in healthy athletes. Clin Chem Lab Med. 2006;44:999-1003

10. Michielsen EC, Wodzig WK, Van Dieijen-Visser MP. Cardiac troponin $t$ release after prolonged strenuous exercise - a review. Sports Med. 2008;38:425-435

11. Latini R, Masson S, Anand IS, Missov E, Carlson M, Vago T, Angelici L, Barlera S, Parrinello G, Maggioni AP, Tognoni G, Cohn JN. Prognostic value of very low plasma concentrations of troponin $\mathrm{t}$ in patients with stable chronic heart failure. Circulation. 2007;116:1242-1249

12. Lam $\mathrm{Q}$, Black M, Youdell O, Spilsbury H, Schneider HG. Performance evaluation and subsequent clinical experience with the abbott automated architect stat troponin-i assay. Clin Chem. 2006;52:298-300

13. Hickman PE, Koerbin G, Southcott E, Tate J, Dimeski G, Carter A, McGill D, Talaulikar G, Potter JM. Newer cardiac troponin i assays have similar performance to troponin $t$ in patients with endstage renal disease. Ann Clin Biochem. 2007;44:285-289 
14. Apple FS, Jesse RL, Newby LK, Wu AH, Christenson RH, Cannon CP, Francis G, Morrow DA, Ravkilde J, Storrow AB, Tang W, Jaffe AS, Mair J, Ordonez-Llanos J, Pagani F, Panteghini M, Tate J. National academy of clinical biochemistry and ifcc committee for standardization of markers of cardiac damage laboratory medicine practice guidelines: Analytical issues for biochemical markers of acute coronary syndromes. Clin Chem. 2007;53:547-551

15. Thygesen K, Alpert JS, White HD, Jaffe AS, Apple FS, Galvani M, Katus HA, Newby LK, Ravkilde J, Chaitman B, Clemmensen PM, Dellborg M, Hod H, Porela P, Underwood R, Bax JJ, Beller GA, Bonow R, Van Der Wall EE, Bassand JP, Wijns W, Ferguson TB, Steg PG, Uretsky BF, Williams DO, Armstrong PW, Antman EM, Fox KA, Hamm CW, Ohman EM, Simoons ML, Poole-Wilson PA, Gurfinkel EP, Lopez-Sendon JL, Pais P, Mendis S, Zhu JR, Wallentin LC, Fernandez-Aviles F, Fox KM, Parkhomenko AN, Priori SG, Tendera M, Voipio-Pulkki LM, Vahanian A, Camm AJ, De Caterina R, Dean V, Dickstein K, Filippatos G, Funck-Brentano C, Hellemans I, Kristensen SD, McGregor K, Sechtem U, Silber S, Tendera M, Widimsky P, Zamorano JL, Morais J, Brener S, Harrington R, Morrow D, Sechtem U, Lim M, Martinez-Rios MA, Steinhubl S, Levine GN, Gibler WB, Goff D, Tubaro M, Dudek D, Al-Attar N. Universal definition of myocardial infarction: Kristian thygesen, joseph s. Alpert and harvey d. White on behalf of the joint esc/accf/aha/whf task force for the redefinition of myocardial infarction. Eur Heart J. 2007;28:2525-2538

16. Panteghini M, Pagani F, Yeo KT, Apple FS, Christenson RH, Dati F, Mair J, Ravkilde J, Wu AH. Evaluation of imprecision for cardiac troponin assays at low-range concentrations. Clin Chem. 2004;50:327-332

17. Giannitsis E, Katus HA. Comparison of cardiac troponin $t$ and troponin $i$ assays--implications of analytical and biochemical differences on clinical performance. Clin Lab. 2004;50:521-528

18. Panteghini M. The new definition of myocardial infarction and the impact of troponin determination on clinical practice. Int J Cardiol. 2006;106:298-306

19. Apple FS, Murakami MM. Serum and plasma cardiac troponin i 99th percentile reference values for 3 2nd-generation assays. Clin Chem. 2007;53:1558-1560

20. International Federation of Clinical Chemistry Committee on Standardization of Markers of Cardiac Damage. (Accessed September 2008)

http://www.ifcc.org/index.php?option=com_remository\&Itemid=120\&func=fileinfo\&id=87.

21. Kurz K, Giannitsis E, Zehelein J, Katus HA. Highly sensitive cardiac troponin t values remain constant after brief exercise- or pharmacologic-induced reversible myocardial ischemia. Clin Chem. 2008;54:1234-1238

22. Wallace TW, Abdullah SM, Drazner MH, Das SR, Khera A, McGuire DK, Wians F, Sabatine MS, Morrow DA, de Lemos JA. Prevalence and determinants of troponin $t$ elevation in the general population. Circulation. 2006;113:1958-1965

23. Olivetti G, Giordano G, Corradi D, Melissari M, Lagrasta C, Gambert SR, Anversa P. Gender differences and aging: Effects on the human heart. J Am Coll Cardiol. 1995;26:1068-1079

24. Salton CJ, Chuang ML, O'Donnell CJ, Kupka MJ, Larson MG, Kissinger KV, Edelman RR, Levy D, Manning WJ. Gender differences and normal left ventricular anatomy in an adult population free of hypertension. A cardiovascular magnetic resonance study of the framingham heart study offspring cohort. J Am Coll Cardiol. 2002;39:1055-1060

25. Tate JR, Ferguson W, Bais R, Kostner K, Marwick T, Carter A. The determination of the 99th centile level for troponin assays in an australian reference population. Ann Clin Biochem. 2008;45:275-288

26. Wu AHB, Fukushima N, Puskas R, Todd J, Goix P. Development and preliminary clinical validation of a high sensitivity assay for cardiac troponin using a capillary flow (single molecule) fluorescence detector. Clin Chem. 2006;52:2157-2159

27. Todd J, Freese B, Lu A, Held D, Morey J, Livingston R, Goix P. Ultrasensitive flow-based immunoassays using single-molecule counting. Clin Chem. 2007;53 


\section{Chapter 4}

28. Melanson SE, Tanasijevic MJ, Jarolim P. Cardiac troponin assays: A view from the clinical chemistry laboratory. Circulation. 2007;116:e501-504

29. Wu AH, Jaffe AS. The clinical need for high-sensitivity cardiac troponin assays for acute coronary syndromes and the role for serial testing. Am Heart J. 2008;155:208-214

30. Shave R, George K, Gaze D. The influence of exercise upon cardiac biomarkers: A practical guide for clinicians and scientists. Curr Med Chem. 2007;14:1427-1436

31. Neilan TG, Januzzi JL, Lee-Lewandrowski E, Ton-Nu TT, Yoerger DM, Jassal DS, Lewandrowski KB, Siegel AJ, Marshall JE, Douglas PS, Lawlor D, Picard MH, Wood MJ. Myocardial injury and ventricular dysfunction related to training levels among nonelite participants in the boston marathon. Circulation. 2006;114:2325-2333

32. Shave R, George KP, Atkinson G, Hart E, Middleton N, Whyte G, Gaze D, Collinson PO. Exerciseinduced cardiac troponin t release: A meta-analysis. Med Sci Sports Exerc. 2007;39:2099-2106

33. Siegel AJ, Januzzi J, Sluss P, Lee-Lewandrowski E, Wood M, Shirey T, Lewandrowski KB. Cardiac biomarkers, electrolytes, and other analytes in collapsed marathon runners: Implications for the evaluation of runners following competition. Am J Clin Pathol. 2008;129:948-951

34. Koller A. Exercise-induced increases in cardiac troponins and prothrombotic markers. Med Sci Sports Exerc. 2003;35:444-448

35. Neumayr G, Gaenzer H, Pfister R, Sturm W, Schwarzacher SP, Eibl G, Mitterbauer G, Hoertnagl H. Plasma levels of cardiac troponin i after prolonged strenuous endurance exercise. Am J Cardiol. 2001;87:369-371, A310

36. Neumayr G, Pfister R, Mitterbauer G, Maurer A, Gaenzer H, Sturm W, Hoertnagl H. Effect of the "race across the alps" in elite cyclists on plasma cardiac troponins i and t. Am J Cardiol. 2002;89:484486

37. Katus HA, Remppis A, Scheffold T, Diederich KW, Kuebler W. Intracellular compartmentation of cardiac troponin $\mathrm{t}$ and its release kinetics in patients with reperfused and nonreperfused myocardial infarction. Am J Cardiol. 1991;67:1360-1367

38. Michielsen EC, Diris JH, Kleijnen VW, Wodzig WK, Van Dieijen-Visser MP. Investigation of release and degradation of cardiac troponin $\mathrm{t}$ in patients with acute myocardial infarction. Clin Biochem. 2007;40:851-855

39. Hessel MH, Atsma DE, van der Valk EJ, Bax WH, Schalij MJ, van der Laarse A. Release of cardiac troponin i from viable cardiomyocytes is mediated by integrin stimulation. Pflugers Arch. 2008;455:979-986

40. Herrmann M, Scharhag J, Miclea M, Urhausen A, Herrmann W, Kindermann W. Post-race kinetics of cardiac troponin $\mathrm{t}$ and $\mathrm{i}$ and $\mathrm{n}$-terminal pro-brain natriuretic peptide in marathon runners. Clin Chem. 2003;49:831-834

41. Whyte G, George K, Shave R, Dawson E, Stephenson C, Edwards B, Gaze D, Oxborough D, Forster J, Simspon R. Impact of marathon running on cardiac structure and function in recreational runners. Clin Sci (Lond). 2005;108:73-80 


\section{CHAPTER 5}

\section{Ischemia and mechanical stretch in cultured cardiomyocytes and their varying effects on cardiac troponin release and degradation}

\section{SUMMARY}

Background: The cardiac troponins (cTn), both I (cTnI) and T (cTnT) are the most important markers used in the diagnosis of acute coronary syndromes (ACS) Nevertheless, they can be elevated in the absence of ACS (i.e. after strenuous exercise). It is unclear if these elevations represent irreversible cardiomyocyte-death or leakage from viable, reversibly damaged, cardiomyocytes. By subjecting cultured cardiomyocytes to ischemia or mechanical stretch we aim to identify if cTn can be released from reversibly damaged cardiomyocytes. Moreover, we aim to identify whether different cardiac stressors induce the formation and release of different molecular forms of cTn.

Methods: HL-1 cardiomyocytes were subjected to ischemia or mechanical stretch for progressive lengths of time. Ischemia was modeled by anoxia with glucose deprivation and mechanical stretch was induced by electric-field stimulation at $3 \mathrm{~Hz}$ (tachypacing). The $c T n$ content of both the collected culture media and cell lysates were determined and Western blots were made to analyze the molecular forms of the cTns. Cell-viability is determined by lactate dehydrogenase $(\mathrm{LDH})$ assay.

Results: The cardiac troponins were only released into the medium together with $\mathrm{LDH}$. However, before LDH was released there was already a significant decrease in the cellular content of the cTns in response to ischemia (50\% for cTnI and $20 \%$ for cTnT) and tachypacing (37\% for cTnI and $21 \%$ for cTnT). The ischemia treatment induced a more rapid cellular decrease of $c T n I$ than $c T n T$, and after 24 hours the relative intracellular amount of cTnT had increased 16-fold. Westernblots of the ischemic cells showed an increase in the relative amount of fragmented cTnI (25 kDa fragment) and cTnT (27 kDa) whereas the tachypaced cells did not.

Conclusion: Our results show differences in the cellular fate of the cardiac troponins in response to different stimuli. 


\section{Introduction}

Cardiac troponin I (cTnI) and $\mathrm{T}(\mathrm{cTnT})$ are accurate and sensitive markers of cardiac injury and the most important biochemical markers used in the diagnosis of acute myocardial infarction (AMI). ${ }^{1,2}$ Nevertheless, the cardiac troponins (cTns) can be elevated in the absence of AMI, in situations where irreversible cardiomyocyte damage is unlikely to play an important role. ${ }^{3,4}$ Prominent in the debate concerning these unexplained cTn elevations are the elevations seen in subjects after strenuous exercise. ${ }^{5-10}$

It has been hypothesized that the elevated levels of cTn seen after exercise are the result of a transient increase in the cardiomyocyte membrane permeability, resulting in the "leakage" of cytosolic cTn from reversibly damaged cardiomyocytes. ${ }^{11,} 12$ This hypothesis might explain the differences in the release kinetics of the cTns after strenuous exercise, where the cTn increases after exercise appear much earlier and the elevations return to baseline much faster than after AMI. ${ }^{11}{ }^{13}$ The cytosolic release of cTn would not only result in different release kinetics (compared to AMI) but also in differences in the released molecular forms of cTn. For example, a temporary increase in the membrane permeability would only induce the release of free (unbound) cTn from the cytosol, ${ }^{14},{ }^{15}$ whereas irreversible cellular damage will additionally result in the release of cTn (and its complexes) from disintegrating myofibrils. In addition to the presence or absence of myofibrillar cTn, there might also be differences in the presence of cleaved forms of cTn. The cTns are thought to be targets for proteases such as caspase ${ }^{16,17}$ and calpain, ${ }^{18-20}$ which are released during cell-death. Therefore, the degree of cTn degradation is expected to be larger in irreversibly damaged cells. Moreover, the complexed (myofibril bound) forms of cTn might be more susceptible to proteolytic degradation than the free forms, as illustrated by Communal et al., who found that caspase-3 cleaves cTnT when it is in complex with cTnI and TnC, but not as free cTnT. ${ }^{17}$ Some support for this hypothesis comes from the findings by Hessel et al. ${ }^{21}$ who showed the release of intact cTnI from viable cardiomyocytes by stimulation of stretch-responsive integrins. Conversely, irreversible cardiomyocyte damage, induced by metabolic inhibition with sodium azide, induced the simultaneous release of intact and fragmented forms of cTnI and cTnT. ${ }^{21,22}$ 
The examples shown above, further suggest that different cardiac stressors, i.e. mechanical stretch ${ }^{21}$ and ischemia, ${ }^{21,22}$ can result in the release of different molecular forms of cTn. Other studies also indicate stimulus dependent differences in the fragmentation of the cTns. For example, Feng et al. showed the formation of cTnI degradation products after increased preload. ${ }^{23}$ Their findings suggest that the proteolysis of $\mathrm{cTnI}$ is the result of increased diastolic pressure and largely independent from ischemia.23 In other words, mechanical stretch to the cardiomyocytes induces cTnI degradation. Others have also show N-terminal degradation of cTnT into a $27-\mathrm{kd}$ fragment in mice.24, 25 To date, it is unclear how and under which conditions the described cTnT and cTnI fragments are released. Clarifying the release kinetics of cTn and its molecular forms in various clinical conditions can further improve the diagnostic potential of the cTns. In this pilot study we investigated the release kinetics of $\mathrm{cTnT}$ and $\mathrm{cTnI}$ and its molecular fragments in response to the cardiac stressors seen during ischemic cardiac damage and strenuous exercise. This is achieved by subjecting HL-1 cardiomyocytes to ischemic or mechanical stressors for progressive lengths of time. By using HL-1 atrial cardiomyocytes, a cell line which continuously divides, spontaneously contracts and maintains a differentiated cardiac phenotype, ${ }^{26}$ the control and reproducibility of the experiments are greatly enhanced. The aims of our study were, firstly, to investigate if the cTns can be released from reversibly damaged cardiomyocytes that still have an intact plasma membrane. This is done by comparing the release kinetics of the cTns with that of lactate dehydrogenase (LDH). The cytosolic protein LDH is released from cells exhibiting a loss of membrane integrity as seen during primary and secondary necrosis and its release is commonly used to quantify cell-death. ${ }^{22,27}$ Secondly, by comparing the cTnI and cTnT concentrations in both cell lysates and culture medium we aim to identify possible stimulus dependent differences in the release characteristics of the cardiac troponins. The third aim of our study was to characterize the molecular forms of $\mathrm{cTnT}$ and $\mathrm{cTnI}$ that are generated in response to the varying stimuli and to identify stimulus dependent differences between them. To do so, the molecular forms of cTnT and cTnI are examined using Western blot analysis. 


\section{Materials and Methods}

\section{Cell culture of HL-1 atrial cardiomyocytes}

HL-1 cells were kindly provided by W. Claycomb (Louisiana State University, New Orleans, LA, USA), and cultured as described previously. ${ }^{28,}{ }^{29}$ Briefly, the cells were grown in Claycomb medium ${ }^{29}$ supplemented with $10 \%$ Fetal Bovine Serum (FBS), $0.1 \mathrm{mM}$ norepinephrine, $2 \mathrm{mM}$ L-glutamine, $100 \mathrm{U} / \mathrm{ml}$ penicillin and 100 $\mu \mathrm{g} / \mathrm{ml}$ streptomycin at $37^{\circ} \mathrm{C}$ and $5 \% \mathrm{CO}_{2}$. For routine passaging, the cells were maintained in T-75 flasks and split twice a week after reaching confluence, as described previously. ${ }^{28}$ For each of our experimental conditions the cells were seeded onto 6-well culture plates at a density of 100000 cells $/ \mathrm{cm}^{2}$ and grown for 24 hours in supplemented Claycomb medium prior to the experimental treatment. The medium used for the experimental treatment of the HL-1 cells consisted of Dulbecco's modified eagle medium (DMEM), supplemented with $2 \mathrm{mM}$ Lglutamine, $100 \mu \mathrm{M} / \mathrm{L}$ non-essential amino-acids (NEAA), 0.5\% albumin, $100 \mathrm{U} / \mathrm{ml}$ penicillin, $100 \mu \mathrm{g} / \mathrm{ml}$ streptomycin; with or without $4.5 \mathrm{~g} / \mathrm{L}$ glucose.

\section{Ischemia / Anoxia and glucose deprivation}

Ischemia was modeled by anoxia and glucose deprivation. At the start of our experiment $(\mathrm{t}=0)$ the culture medium was replaced with the supplemented DMEM medium without glucose and the cells were immediately placed in an anoxic environment (MACS VA500 microaerophilic workstation, Don Whitley Scientific, Shipley, UK). The atmosphere in the chamber consisted of $5 \% \mathrm{CO}_{2}, 5 \% \mathrm{H}_{2}$ and residual $\mathrm{N}_{2}$. Anoxia treatment is performed for 1, 3, 5, 7, 9, 12 and 24 hours.

\section{Electric-field stimulation / Tachypacing}

The increased contraction rate and mechanical stress, seen during strenuous exercise was modeled by rapid electric field stimulation (tachypacing). At $t=0$ the culture medium was replaced with supplemented DMEM medium (with glucose) and electrical pacing was immediately induced. The cells were paced using a Cpace Stimulator and 6-well C-Disch Culture Dish Electrodes from IonOptix (Milton, MA, USA). Electric-field stimulation was performed at $40 \mathrm{~V}$ with a frequency of $3 \mathrm{~Hz}$ and a pulse duration of $5 \mathrm{~ms}$. The electrical stimulation was 
performed for 1, 3, 5, 7 and 9 hours, whereby pacing for the 9 hour plate was initiated after the 1 hour treatment was finished (due to a limited availability of culture dish electrodes) .

\section{Control condition}

As a control, non-treated, HL-1 cells, grown for 0, 1, 3, 5, 7, 9, 12 and 24 hours in supplemented DMEM medium with glucose were grown alongside the ischemic and tachypaced cells.

\section{Sample collection and cardiac troponin measurements}

After each treatment period, the culture medium was collected and centrifuged for 5 minutes at $500 \mathrm{RCF}$ and the supernatant was stored at $-80^{\circ} \mathrm{C}$. Immediately after medium removal the cells were washed twice with cold $\left(4{ }^{\circ} \mathrm{C}\right) \mathrm{PBS}$ and $600 \mu \mathrm{L}$ cold $\left(4{ }^{\circ} \mathrm{C}\right)$ RIPA lysis buffer, containing $150 \mathrm{mM} \mathrm{NaCl}, 50 \mathrm{mM}$ Tris- $\mathrm{HCl}, 1 \%(\mathrm{v} / \mathrm{v})$ Igepal CA-630, 0.5\% (w/v) sodium deoxycholate, $0.1 \%(\mathrm{w} / \mathrm{v})$ SDS, $4 \%(\mathrm{v} / \mathrm{v})$ Complete protease inhibitor cocktail and 5\% (v/v) PhosSTOP phosphatase inhibitor cocktail, was added to each well. The plates were put on ice and the cells were lysed for 2 hours with mild agitation at $4{ }^{\circ} \mathrm{C}$. After the incubation, the cell lysates were transferred to eppendorf tubes and centrifuged for 15 minutes at maximum speed at $4{ }^{\circ} \mathrm{C}$. The supernatant was stored at $-80{ }^{\circ} \mathrm{C}$. CTnT concentrations were measured using the $4^{\text {th }}$ generation $\mathrm{CTnT}$ immunoassay on the Elecsys 2010 (Roche Diagnostics, Mannheim, Germany). CTnI concentrations were measured using the AxSYM $^{\circledast}$ Troponin-I ADV assay (Abbott Diagnostics, Wiesbaden, Germany).

\section{Cell death}

The release of lactate dehydrogenase (LDH) into the extracellular medium was used to quantify cell death. We determined the LDH activity in both the collected culture media and cell lysates using the LD-P lactate dehydrogenase assay on the Synchon LX20 pro clinical system (Beckman Coulter Inc., Palo Alto, CA, USA). The release of $\mathrm{LDH}$ is expressed as the $\mathrm{LDH}$ activity in the culture medium as a percentage of the total $\mathrm{LDH}$ in the well: (LDHmedium / LDHmedium + LDHlysates) ${ }^{*} 100 \%$. 
In addition to the LDH release, the amount of "living cells" was also estimated by measuring the total protein content in the collected cell lysates with the BCA Protein Assay Reagent (bicinchoninic acid) (Thermo Fisher Scientific, Inc., MA, USA).

\section{Immunoprecipitation of cTnI and cTnT from culture media.}

The cell culture medium samples generally contained very low concentrations of cTnT and cTnI, moreover, the albumin present in the culture medium interfered with the SDS-electrophoresis and western blot procedure described below. To circumvent these limitations we performed a highly specific immunoprecipitation for cTnI and cTnT using the anti-cTnI and cTnT monoclonal antibodies (mAbs) employed in the cTnI (Axsym) and cTnT (Elecsys) assays. The epitopes recognized by the M11.7 mAb from the cTnT assay are directed against amino acid residues (a.a.r.) 125-131 and for the $\mathrm{cTnI}$ assay the Mabs are directed against epitopes a.a.r. 41-49 and 87-91. For cTnT we incubated $10 \mu \mathrm{g}$ of biotinylated M11.7 (reagent 2 in the $4^{\text {th }}$ generation assay, $1.5 \mathrm{mg} / \mathrm{L}$ ) with streptavidin coated magnetic beads (Dynabeads, M270 Streptavidin, Invitrogen) for 90 minutes at room temperature. Subsequently, the beads were washed and crosslinked three times with dimethyl pimelimidate dihydrochloride (DMP, Sigma-Aldrich) as described previously ${ }^{30}$. For cTnI, the microparticles from the Axsym kit were already conjugated with the anti cTnI antibodies.

Before the immunoprecipitation all culture medium samples were diluted to the same cTnT or cTnI concentrations. The immunoprecipitation was performed by incubating $400 \mu \mathrm{L}$ of cell culture medium sample to $50 \mu \mathrm{L}$ of beads for 1 hour at $4^{\circ} \mathrm{C}$. The cTnT and cTnI are eluted from the beads with $50 \mu \mathrm{L}$ of $1 \mathrm{M}$ glycine $(\mathrm{pH}$ $=3$ ), for 15 minutes at $56^{\circ} \mathrm{C}$.

\section{Detection of $\mathrm{cTnI}$ and $\mathrm{cTnT}$ degradation products in cell lysates and medium}

Before separating the proteins, the cell lysates were all diluted to the same cTnT or cTnI concentrations. The cell culture lysates and immunoprecipitation eluates were each mixed with 4x XT Sample Buffer (Bio-Rad, 161-0791) and 20x Reducing Agent (Bio-Rad, 161-0792) and heated for 5 minutes at $95^{\circ} \mathrm{C}$. Subsequently, $25 \mu \mathrm{l}$ of the samples, containing equal amounts of $\mathrm{CTnT}$ and $\mathrm{cTnI}$ (see results section) was 
separated on a $12 \%$ Criterion XT SDS-PAGE gel (Bio-Rad, 345-0118). Gels were transferred to a nitrocellulose membrane (Bio-Rad, 162-0115, $0.45 \mu \mathrm{m}$ ). Further treatment of the blots was done with the SNAP i.d. protein detection system (Millipore) according to the manufacturer's instructions. Briefly, blocking was performed for $10 \mathrm{sec}$ with $0.5 \%$ Blocking buffer (Bio-Rad, 170-6404). The incubation with the primary antibody (specified below) was performed for 10 minutes. After washing (washed $4 \mathrm{x}$ with PBS with $0.1 \%$ Tween-20 (PBST)), the blot was incubated with secondary antibody (specified below) and washed $4 \mathrm{x}$ with PBST. The following primary and secondary antibodies were used:

For cTnT the primary anti-cTnT solution was $10 \mu \mathrm{g} / \mathrm{mL}$ Roche M7 (as kindly provided by Roche Diagnostics, epitope a.a.r. 136-147) in PBST. Alternatively we used a mix of anti cTnT mAbs: 9G6 (epitope: 1-60 ), 1c11 (epitope: 95-181), 7F4 (epitope: 60-70), 7A9 (epitope:180-287) (all mAbs ordered from Hystest LTD, Turku, Finland) at a concentrations of $2 \mu \mathrm{g} / \mathrm{mL}$. For the cTnT blots the secondary antibody solution consisted of $0.4 \mu \mathrm{g} / \mathrm{mL}$ goat anti-mouse IgG conjugated with peroxidase (Dako, P0447) in PBST. To blot cTnI we used the primary anti-cTnI solution from the Troponin-I ADV assay (Abbott, reagent 3, epitope a.a.r. 24-40) diluted 1:1 with PBST. Secondary antibody solution for CTnI was streptavidin-HRP (R\&D systems, 890803) 200-fold diluted in PBST. Alternatively we used a mix of 3 anti-cTnI mAbs: 19C7 (epitope: 41-49 ), MF4 (epitope: 190-196 ) and 84 (epitope: 117-126) (all mAbs ordered from Hystest) at a concentrations of $4 \mu \mathrm{g} / \mathrm{mL}$. The secondary antibody solution consisted of $0.4 \mu \mathrm{g} / \mathrm{mL}$ goat anti-mouse $\operatorname{IgG}$ conjugated with peroxidase (Dako, P0447) in PBST. Subsequently, membranes were incubated for 5 minutes in Super Signal West Femto Substrate (Thermo Scientific, 34096) and exposure was detected using the ChemiDoc XRS scanner (Bio-Rad).

\section{Data analysis and statistics}

Experiments were performed in triplicate and data are presented as mean $+/-$ S.E.M. Comparisons are made with using Student's paired t-test with $\mathrm{p}<0.05$ considered statistically significant. Protein release (for cTnI, cTnT and LDH) is defined as the percentage of total protein that is present in the medium: Release $=$ $[\mathrm{Pm}] /[\mathrm{Pm}+\mathrm{Pl}] * 100 \% ; \mathrm{Pm}=$ protein amount in the medium and $\mathrm{Pl}$ is the protein 


\section{Chapter 5}

amount in the cell lysate. The recovery of each of the proteins is defined as the amount of protein that can be recovered at each time point, relative to the amount in the control: $($ Recovery $=[\mathrm{Pl}+\mathrm{Pm}]$ in the experimental condition $) /([\mathrm{Pl}+\mathrm{Pm}]$ in the control) $* 100 \%$. The relative amount of intact and fragmented cTnI and cTnT were determined by densitometry, using the Quantity One software (Bio-Rad, Version 4.6.5.).

\section{Results}

\section{Ischemic damage and cell death}

In the first part of our experiments we modeled the ischemic damage seen during AMI by replacing the culture medium with medium without glucose and by placing the cells in an anoxic environment.

To investigate the effects of the ischemic treatment on the viability of the cells we determined the amount of LDH that is released into the medium. Figures $1 \mathrm{a}$ and $\mathrm{b}$ show the amount of LDH present in the cell culture lysates and culture media in ischemia treated and control cells, respectively. As can be seen by comparing these figures, the decrease in the cellular amount of LDH upon ischemic treatment is mirrored by the amount of LDH released into the medium. The total amount of $\mathrm{LDH}$ in the ischemia treated cells is roughly similar to the total amount in the control cells (on average 107.5\% $\pm 4.7 \%$ ). As can be seen in figure 1c, which visualizes the total recovery of $\mathrm{LDH}$ compared to the control condition, the recovery of $\mathrm{LDH}$ is independent from the duration of the treatment.

During the first three hours of treatments, the release of LDH into the medium (and thus irreversible damage to the membrane integrity) does not exceed that in the control condition. As can be seen in figure 1d, the release of LDH increases strongly after 5 hours of treatment $(65 \% \pm 6 \%$ release) and after 9 hours of treatment $(94 \% \pm 1 \%$ release) the release curve reaches a plateau phase. LDH release in the control condition only increases between 12 and 24 hours, suggesting a loss of membrane integrity as a result of medium depletion. Of note, as an alternative measure of cell viability we analyzed the total protein content of the cell lysates (results not shown) and the total protein and LDH content in the lysates of 
the ischemia treated cells showed an excellent correlation (Spearmans rho $=0.843$, $\mathrm{p}<0.001)$.

a)

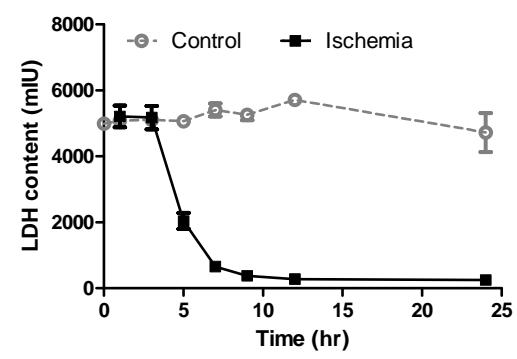

c)

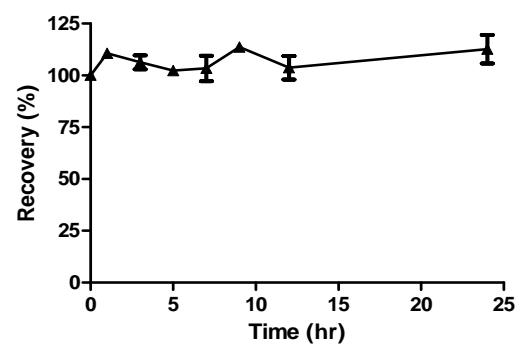

b) LDH in cell culture media

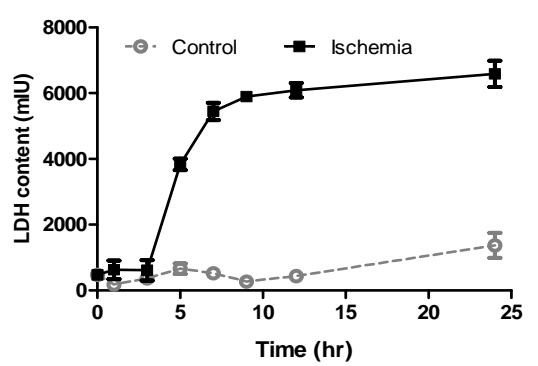

d)

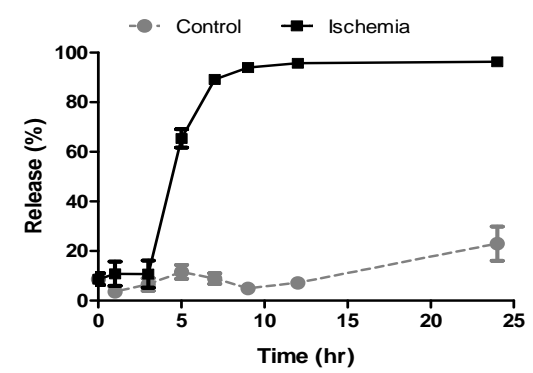

Figure 1. a) The cellular content of lactate dehydrogenase (LDH) in the ischemia treated and control cells. b) The LDH content in the cell culture medium of ischemic and control cells. c) The recovery of LDH: the total amount of LDH (in medium + lysates) in the ischemia treated cells relative to the amount of LDH in the control cells. $\mathbf{d}$ ) The release of LDH in ischemia treated and control cells.

\section{Ischemic damage and the cardiac troponins}

Figure 2a shows the changes in the total amount of $c \operatorname{TnI}$ and $c \operatorname{TnT}$ in ischemia treated and in control cells. During the first 3 hours, there is no decrease in the cellular content of LDH, but cTnI levels have dropped by about $52 \%$ and cTnT by $23 \%$. The cellular decrease in the cTns during the first 3 hours are not directly matched by an increase in the medium. After that period, the decrease in the lysates is matched by an increase in the medium. So during the first few hours of treatment not all cTnI and cTnT is recovered and there seems to be a considerable loss of the cTns. This is perhaps better illustrated by showing the total recovery of the cTnI, cTnT (and LDH for comparison) in figure 2c. Note that the recovery for cTnI decreases rapidly during the first three hours, but does not decline further during the treatment. For CTnT there is a similar, but slightly delayed trend and 
during the first 7 hours of treatment the recovery drops strongly, after which it does not decline further. The slight increase in the recovery of cTnI and cTnT, seen after 24 hours of treatment can be explained by the fact that (due to substrate depletion) there is a decrease in the cellular content of cTnI and cTnT in the control condition. We will come back to the decreased recovery when we discuss the results of our Western blot experiments.

With respect to the release characteristics, we note that both the decrease in cellular cTnI and the increase in the culture medium occur more rapidly than for cTnT. This is best illustrated by the release curves in figure $2 \mathrm{~d}$, which show that after 5 hours of ischemic treatment approximately $68 \%( \pm 12)$ of the available cTnI is released into the medium compared to only $11 \%( \pm 8)$ for cTnT. In addition to the slower release of cTnT, the maximum cTnT release is also lower than that of cTnI and LDH. This observation would suggest that cTnT remains in the cell lysates longer than cTnI and LDH. To test this, we plotted the relative amounts of cTnT and cTnI per LDH in the cell lysates (figure 2e). Within the cell lysates the relative amount of cTnT (relative to LDH) increases during progressive lengths of ischemia treatments, whereas the relative amount of cTnI decreases. After 24 hours of treatment the relative amount of cTnT per $\mathrm{LDH}$ is increased $2.9( \pm 0.2)$ times compared to the control, compared to a factor $0.18( \pm 0.03)$ for cTnI per LDH. When directly compared to cTnT (figure $2 \mathrm{f}$ ) the relative amount of cTnT versus cTnI in the cell lysates increased by a factor of $16.4( \pm 3.3)$ in the $24 \mathrm{~h}$ ischemia treated cells (compared to control cells). 
a)

cTn in cell culture lysates

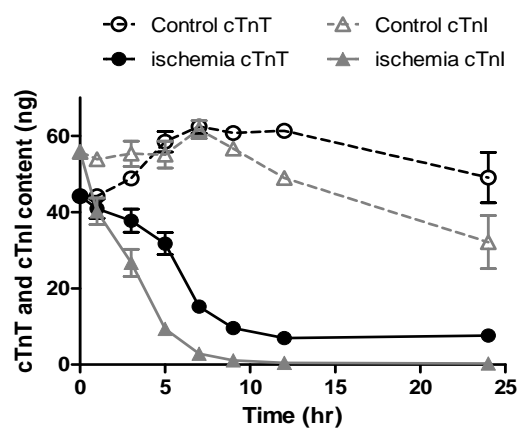

c)

$$
\text { Recovery (as \% of control) }
$$

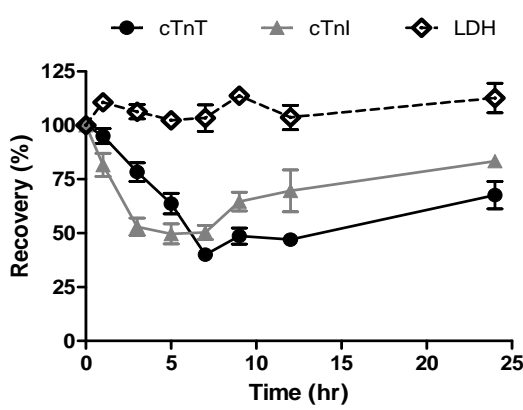

e)

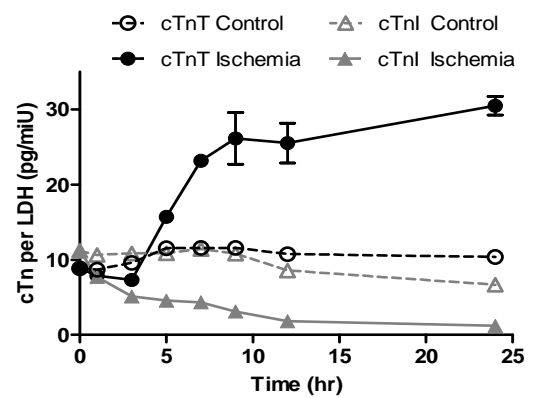

b)

cTn in cell culture medium

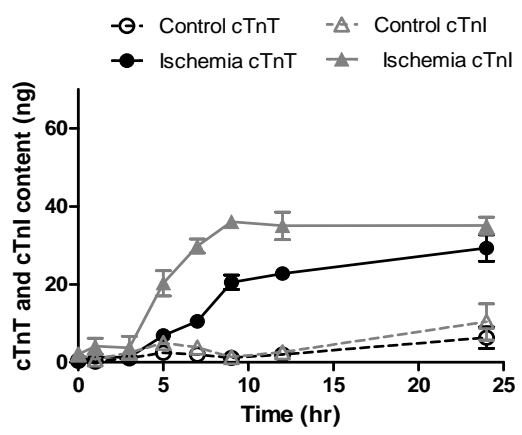

d)

Release ischemia

- Ischemia cTnT - Ischemia cTnl - ischemia LDH -๑- Control CTnT -A. Control cTnl $\quad$ a Control LDH

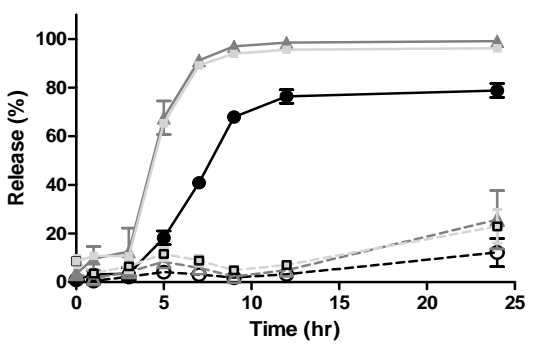

f) cTnT per cTnI in cell lysates

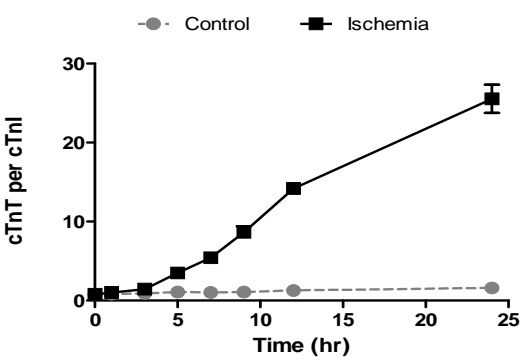

Figure 2 a) The cellular content of $c \operatorname{TnI}$ and $c \operatorname{TnT}$ in ischemia treated and control cells. b) cTnI and cTnT content in the cell culture medium of ischemic and control cells. c) The recovery of the cTns: the total amounts of cTn (in medium + lysates) in the ischemia treated cells relative to the amounts in the control cells. d) The release of cTnI, cTnT and LDH in ischemia treated and control cells. e) The cellular amount of cTnI and cTnI (both in ng) per miU of LDH in both control and ischemia treated cells. f) The cellular amount of cTnT per cTnI in control and ischemia treated cells. 


\section{Ischemia and the molecular forms of cTn}

In the previous section we quantitatively described the cellular cTn concentrations in HL-1 cardiomyocytes and its release into the culture medium in response to modeled ischemia. In this section we investigate if the ischemic treatment of the HL-1 cardiomyocytes induces a change in the generation and release of different molecular forms of cTnT and cTnI.

\section{cTnI in cell culture lysates}

First to be described are the results for cTnI. Before protein separation, the samples were diluted to $1 \mu \mathrm{g} / \mathrm{L}$ when possible. Due to the rapid decrease of cTnI in the ischemia treated cell lysates the 12 hour sample contained slightly less cTnI $(0.7$ $\mu \mathrm{g} / \mathrm{L})$ and the 24 hours sample contained too little cTnI for adequate blotting. In order to enable a comparison between the cTnI measurements with the AxSYM Troponin-I ADV assay we first used the detector antibody from this assay to probe the Western blot. The resulting Western blot in figure 3 shows two separate bands for cTnI, one at $29 \mathrm{kDa}$ and a smaller band at $25 \mathrm{kDa}$. Roughly $93 \%$ of the total signal originates from the $29 \mathrm{kDa}$ band and about $7 \%$ from the $25 \mathrm{kDa}$ band (see quantification in figure 3). During the treatment, the relative amount of the bands does not change with the length of treatment in either the control or the ischemia treated cells.

Next we performed the same Western blot experiment, but this time we used a mix of 3 different anti-cTnI antibodies, each targeted against a different epitope. Results in figure 3 show that for the first 5 hours the results with the antibody mix are virtually the same as for the AxSYM kit antibody. Interestingly, after 5 hours the relative intensity of the $29 \mathrm{kDa}$ and $25 \mathrm{kDa}$ bands begin to change with increasing lengths of ischemia treatment. After 12 hours the relative signal of the $25 \mathrm{kDa}$ band had increased to $37 \%$ (and the $39 \mathrm{kDa}$ decreased to about 33\%). Note that this relative increase in the $25 \mathrm{kDa}$ band was not picked up by the antibody from the AxSYM kit. 

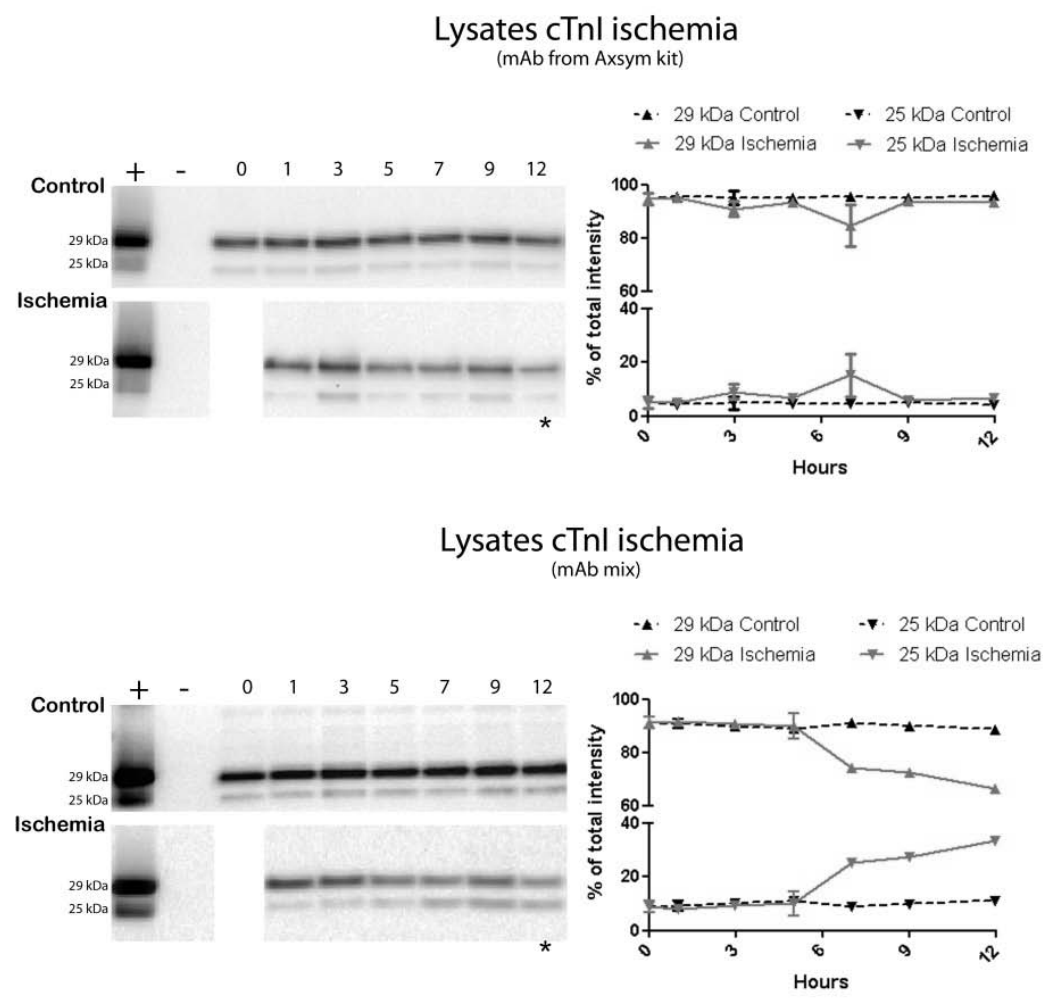

Figure 3. Western blots of ischemia cell culture lysates probed for cTnI. The upper part shows the blot and the intensity quantification after probing with the $\mathrm{cTnI} \mathrm{mAb}$ from the axsym kit. The lower part show the results for probing with the cTnI antibody mix. ${ }^{*} 12$ hour ischemia sample: $\mathrm{cTnI}=0.70 \mu \mathrm{g} / \mathrm{L}$

\section{cTnI in cell culture media}

Next we set out to examine the molecular forms of $c \operatorname{TnI}$ that are released into the medium in response to the ischemia treatment. Before immunoprecipitation (IP) the collected medium samples were diluted to the same cTnI concentration $(0.5$ $\mu \mathrm{g} / \mathrm{L})$. Subsequently, the eluates of the IP were separated and blotted in the same way as the cell lysates. Figure 4 shows the results for the cTnI Western blot of the cell culture media, probed with the Axsym kit antibodies. Results show the presence of only one cTnI reactive band at $29 \mathrm{kDa}$. Regrettably, we could not probe these samples with the cTnI antibody mix because the IP of the beads from the Axsym kit resulted in the release of light and heavy chains from the antibodies on the beads. These light- and heavy chains originating from the beads, react with anti-mouse antibodies in the goat anti-mouse IgG (GAMPO) that we use as a 
secondary antibody to detect the cTnI antibodies from the mix. The antibodies from the kit weren't influenced by the released light and heavy chains because the secondary detection-step is based on a biotin-streptavidin interaction.

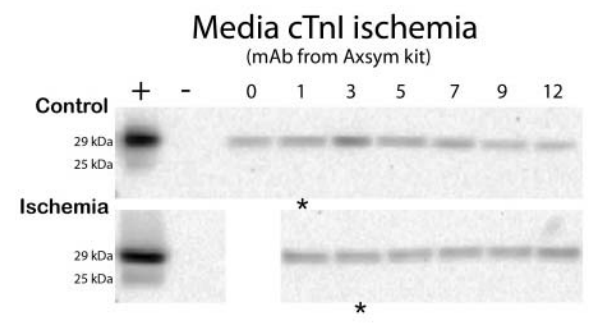

Figure 4: Western blot of ischemia cell culture
media probed for cTnI. Blot was probed with
the cTnI mAb from the axsym kit. ${ }^{*} 1$ hour
control: $c T n I=0.4 \mu \mathrm{g} / \mathrm{L} ;{ }^{*} 3$ hour ischemia:
$\mathrm{cTnI}=0.44 \mu \mathrm{g} / \mathrm{L}$.

cTnT in cell culture lysates

Before protein separation, the samples were diluted to a cTnT concentration of 7,5 $\mu \mathrm{g} / \mathrm{L}$. For a good comparison between the cTnT measurements with the Elecsys cTnT assay, we used the M7 detector antibody from the elecsys kit to probe the Western blot. Figure 5 shows a representative example of the cell lysate Western blot and the summarized quantification of the bands. The Western blot shows two separate immunoreactive bands for cTnT, one at $37 \mathrm{kDa}$ and a smaller band at 27 $\mathrm{kDa}$. In the control samples and during the first hours of ischemia, $99 \%$ of the total troponin signal on the blot originates from the $37 \mathrm{kDa}$ (intact $\mathrm{cTnT}$ ) band. Upon progressive lengths of ischemia treatment the relative amount of the $37 \mathrm{kDa}$ band decreases and that of the $27 \mathrm{kDa}$ band increases. The increase, however, is relatively low and after 12 and 24 hours of ischemia only about $3.3 \%$ and $4.7 \%$ of the total cTnT signal on the blot originates from the $27 \mathrm{kDa}$ band. To test for the presence of other cTnT degradation products we also performed the blotting experiment using a mix of 4 different anti-cTnT mAbs. As can be seen in figure 5 the results are similar to those with the M7 mAbs. 


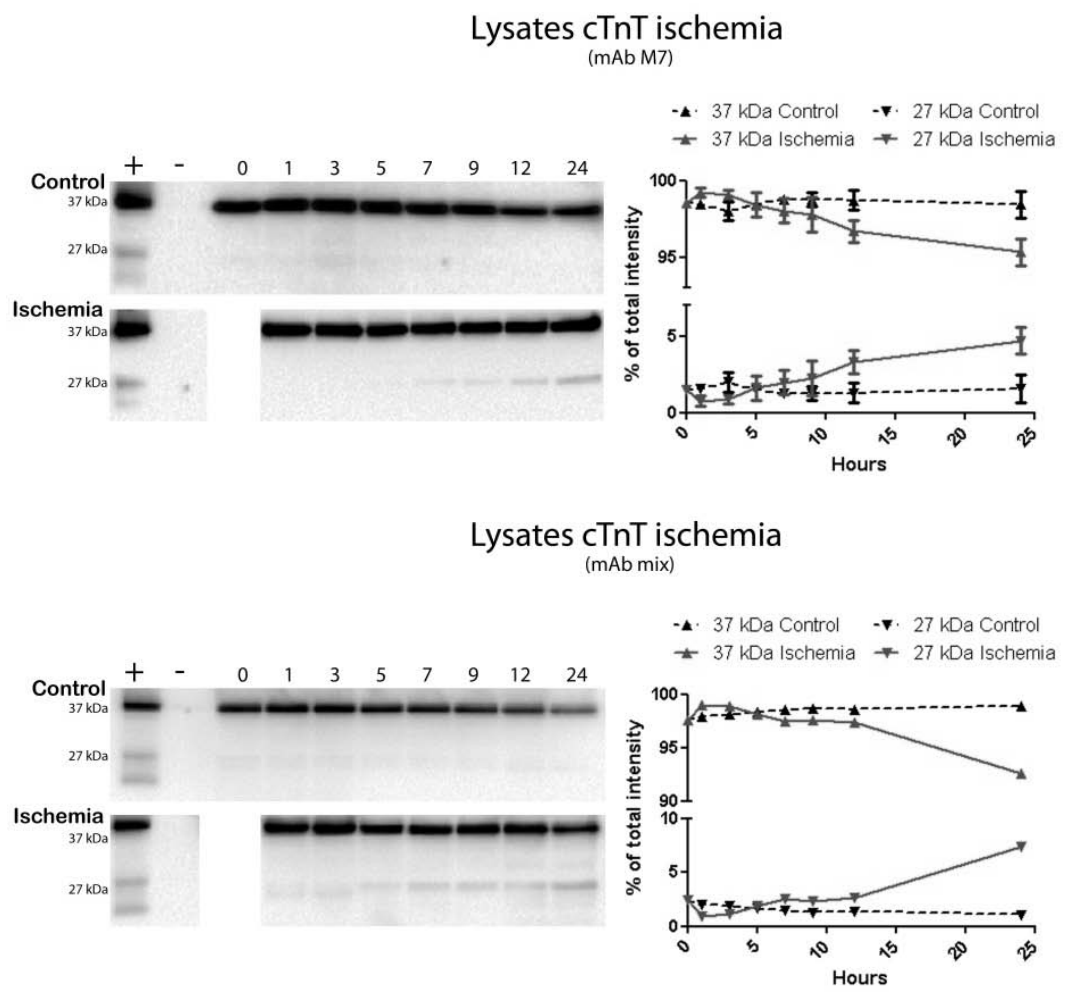

Figure 5. Western blots of ischemia cell culture lysates probed for cTnT. The upper part shows the blot and the intensity quantification after probing with the M7 mAb from the elecsys kit. The lower part show the results for probing with the cTnT antibody mix.

\section{cTnT in cell culture media}

Figure 6 shows a representative example of a Western blot that was made to investigate the molecular forms of cTnT that are released into the culture medium in response to the ischemia treatment. Before immunoprecipitation (IP) the collected medium samples were diluted to the same cTnT concentration $(0.25 \mu \mathrm{g} / \mathrm{L})$ when possible. As there is hardly any release of cTnT from the control cells and during the first hours of the ischemia treatment, not all samples contained enough cTnT to be diluted to $0.25 \mu \mathrm{g} / \mathrm{L}$ (actual pre IP concentrations are given in the text accompanying figure 6).

Our results show that cTnT is only released into the medium in the intact $37 \mathrm{kDa}$ form throughout the entire ischemia treatment. Re-probing the blots with the cTnT antibody mix did not reveal any additional cTnT bands (results not shown). 


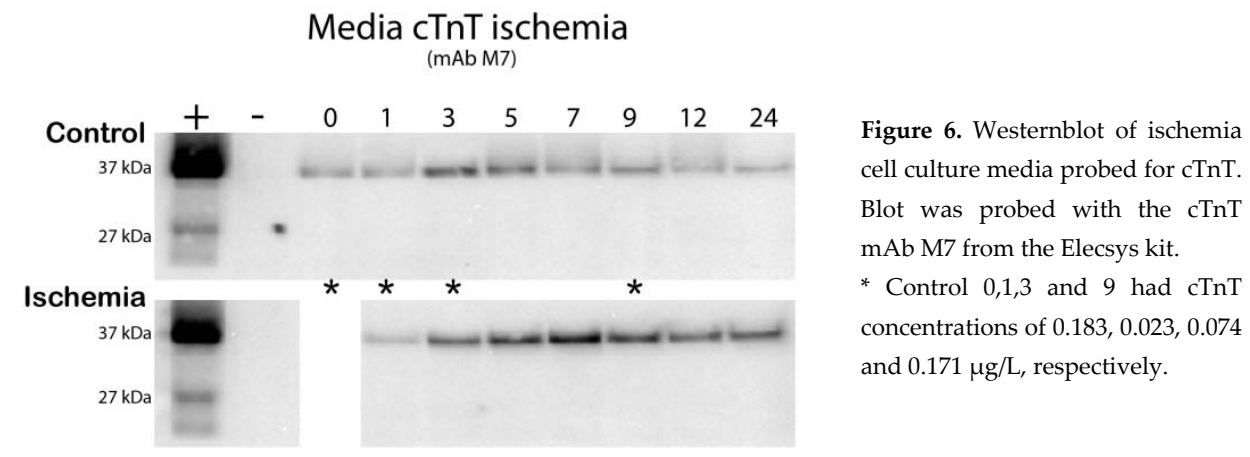

\section{Tachypacing and cell death}

Tachypacing at $3 \mathrm{~Hz}$ induced a gradual decrease in the cellular content of LDH in the HL-1 cells (figure 7a), which is accompanied by an increase in the culture medium (figure $7 \mathrm{~b}$ ). During the 9 hours of tachypacing the total amount of LDH does not change markedly. As can be seen in figure $7 \mathrm{c}$, the recovery of LDH (compared to the control condition) remains relatively constant during the treatment and averages around $99 \%( \pm 11)$.

The release of LDH into the medium in response to tachypacing (figure $7 \mathrm{~d}$ ) is already significant after 3 hours of tachypacing $(18.7 \% \pm 3.2$ in tachypaced cells versus $6.5 \% \pm 4.4$ in the controls, $\mathrm{p}<0.01$ ). Subsequently, the release of $\mathrm{LDH}$ increases further and after 9 hours of pacing $64 \% \pm 3$ of LDH is released into the medium. Note that for the ischemia treated cells (figure 1) the release of LDH had not begun after 3 hours of treatment, but after 9 hours virtually all of the LDH had been released into the medium. So the release of LDH from the tachypaced cells begins slightly earlier, but is more gradual than for the ischemia treated cells. Similarly as for the ischemia treated cells, the total protein content in the cell lysates (results not shown) showed an excellent correlation (Spearmans rho $=0.839$, $\mathrm{p}<0.001$ ) with the LDH content. 
a)

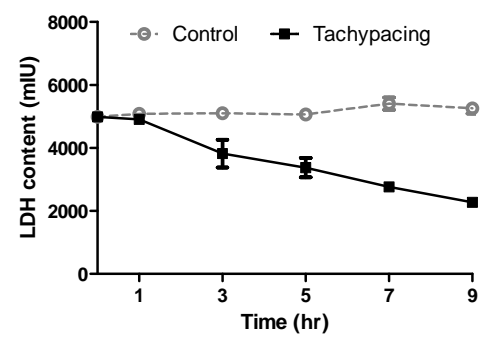

c)

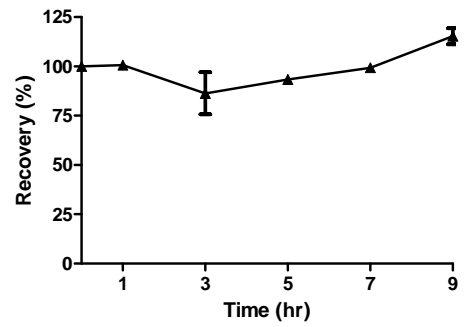

b)

LDH in cell culture media

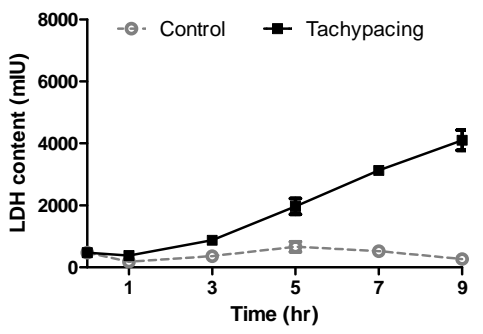

d)

Release tachypacing

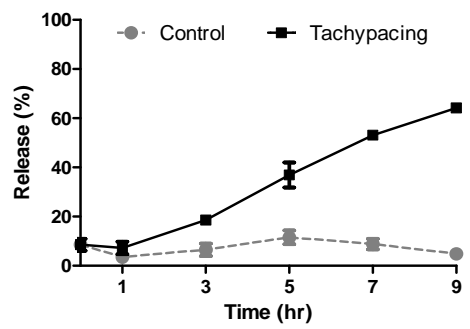

Figure 7a) The cellular content of lactate dehydrogenase (LDH) in the tachypaced (TP) and control cells. b) The LDH content in the cell culture medium of tachypaced and control cells. c) The recovery of LDH: the total amount of LDH (in medium + lysates) in the tachypaced cells relative to the amount of LDH in the control cells. d) The release of LDH in tachypaced and control cells.

\section{Tachypacing and the cardiac troponins}

Above we have shown that there is virtually no change in the cellular content of LDH in the first hour after tachypacing. The cellular cTnI and cTnT content, however, already showed a strong decrease in the first hour after tachypacing (figure 8a). To illustrate: after 1 hour of pacing the cTnI and cTnT content drops by roughly $20 \mathrm{ng}(37 \%)$ and $9 \mathrm{ng}(20 \%)$ compared to the controls, respectively. This decrease seen in the first hour is not matched by an increase in the medium (figure $8 b)$. Similarly as in the ischemia treatment, the total recovery of cTnI and cTnT gradually drops with progressive lengths of treatment, whereby the cTnT recovery exceeds that of cTnI (figure 8c).

The release of cTnT and cTnI into the medium (figure 8d) essentially follows the release of LDH, although the relative amount that is released is higher for $\mathrm{LDH}$ than for cTnI and cTnT. 


\section{Chapter 5}

a)

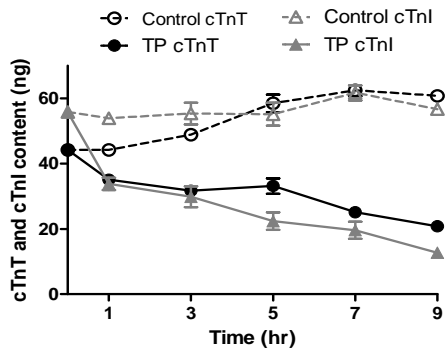

c)

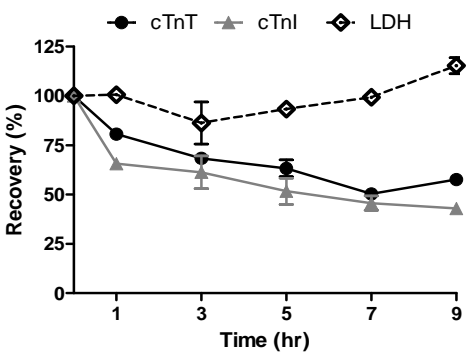

e) cTn per LDH in cell lysates

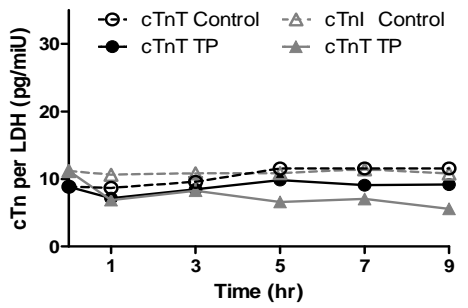

b)

cTn in cell culture medium

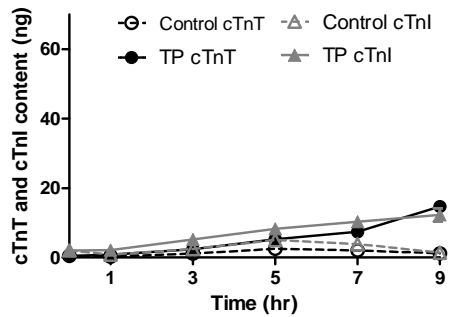

d)

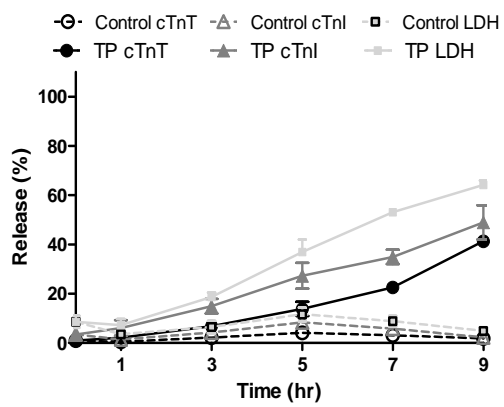

f)

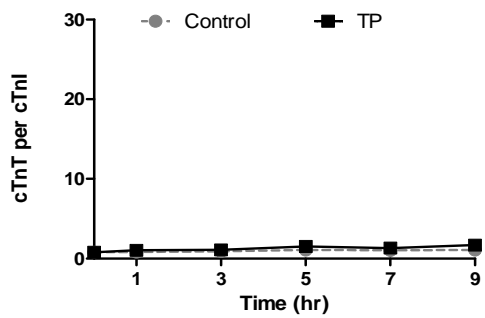

Figure 8a) The cellular content of cTnI and cTnT in tachypaced (TP) and control cells. b) cTnI and cTnT content in the cell culture medium of tachypaced and control cells. c) The recovery of the cTns: the total amounts of cTn (in medium + lysates) in the tachypaced cells relative to the amounts in the control cells. d) The release of cTnI, cTnT and LDH in tachypaced and control cells. e)The cellular amount of cTnI and cTnI (both in ng) per miU of LDH in both control and tachypaced cells. f) The cellular amount of cTnT per cTnI in control and tachypaced cells. 
With respect to the relative amount of cTnI and cTnT compared to LDH in the cell lysates we see that this drops slightly in response to tachypacing (figure 8e), which is in line with the more pronounced decrease of the cTns in the lysates. Within the cells, the relative amounts of cTnT and cTnI do not change markedly in response to tachypacing (figure 8f). Note that this relative stability in the relative cellular amount of LDH, cTnT and cTnI after tachypacing is in contrast with the changes seen in response to the ischemia treatment.

\section{Tachypacing and the molecular forms of cTn}

Figure 9 shows the Western blots that were made to investigate the molecular forms of cTnI present in the tachypaced cells. Similarly as for the ischemia treated samples described above, the lysate samples were diluted to a cTnI concentration of $1 \mu \mathrm{g} / \mathrm{L}$. The first blots were performed using the detector antibody from the AxSYM Troponin-I ADV assay to probe the cTnI on the Western blot. Results show the presence of two immunoreactive bands for cTnI, one at $29 \mathrm{kDa}$ and the other at $25 \mathrm{kDa}$. During the tachypacing treatment the relative amount of these bands (29 $\mathrm{kDa} \approx 93 \%, 25 \mathrm{kDa} \approx 7 \%$ ) does not change compared to the control cells. Next we performed the experiment using the cTnI antibody mix (results in figure.9). Using the cTnI mix we do not see the appearance of additional cTnI bands, nor do we detect a change in the relative amount of the $29 \mathrm{kDa}$ and $25 \mathrm{kDa}$ immunoreactive bands. 


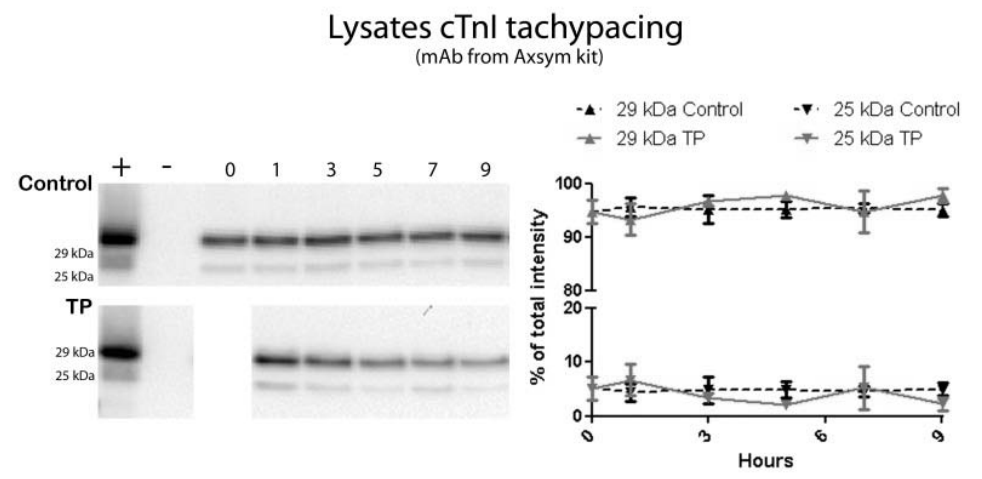

\section{Lysates cTnl tachypacing}

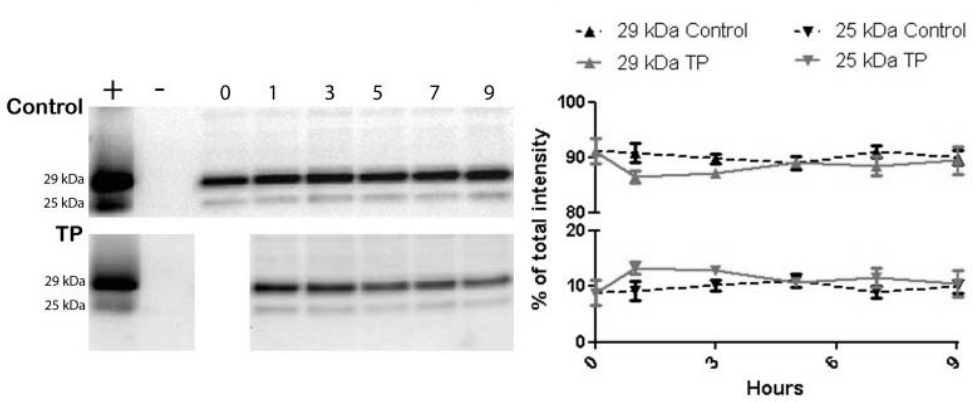

Figure 9. Western blots of tachypaced cell culture lysates probed for cTnI. The upper part shows the blot and the intensity quantification after probing with the cTnI mAb from the axsym kit. The lower part show the results for probing with the cTnI antibody mix.

\section{cTnI in cell culture media after tachypacing}

Before investigating the $\mathrm{cTnI}$ forms released into the medium in response to tachypacing, the medium samples were diluted to a cTnI concentration of $0.5 \mu \mathrm{g} / \mathrm{L}$ and subjected to IP. Subsequently, the eluates of the IP were separated and blotted in the same way as the cell lysates.

In figure 10 we show a Western blot of the cell culture media, probed with the Axsym kit antibodies. Results show the presence of only one cTnI reactive band at $29 \mathrm{kDa}$. As mentioned above, due to cross reactivity of eluted light and heavy chain antibodies we could not probe the samples with our cTnI antibody mix. 


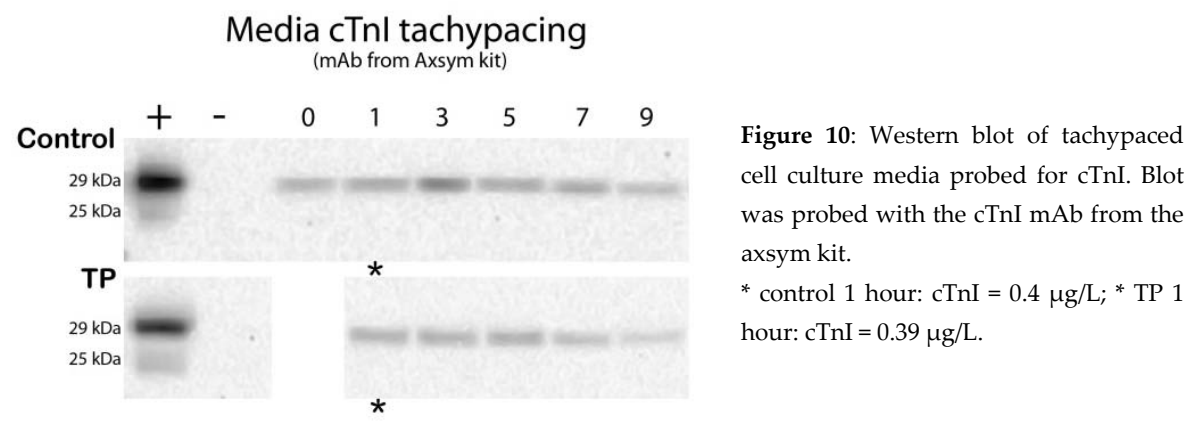

\section{cTnT in cell culture lysates after tachypacing}

Before protein separation, the lysate samples were diluted to a cTnT concentration of $7,5 \mu \mathrm{g} / \mathrm{L}$. Figure 11 shows a representative example of the cell lysate Western blot, probed with the M11.7 mAb and the summarized quantification of the bands. The Western blot showed two separate immunoreactive bands for cTnT, one at 37 $\mathrm{kDa}$ and a smaller (barely visible) band at $27 \mathrm{kDa}$. Roughly $99 \%$ of the cTnT signal originates from the $37 \mathrm{kDa}$ band and this relative amount does not change during the progression of the tachypacing treatment. Results for the Western blot with the cTnT antibody mix do not reveal a different fragmentation pattern than that picked up by the M7 mAb (Figure 11).

\section{CTnT in cell culture media}

Before subjecting the cell culture media to Western blotting, the medium samples were immunoprecipitated using the "catcher" antibody (M11.7) from the Roche Elecsys kit. Before immunoprecipitation (IP) the collected medium samples were diluted to the same cTnT concentration $(0.25 \mu \mathrm{g} / \mathrm{L})$ when possible. As there is hardly any release of cTnT in the first hours of the tachypacing treatment and in the control cells, not all samples contained enough cTnT to be diluted to $0.25 \mu \mathrm{g} / \mathrm{L}$. As can be seen in figure $12, \mathrm{cTnT}$ is only visible in the intact $37 \mathrm{kDa}$ form throughout the entire tachypacing treatment. Re-probing the blots with the cTnT antibody mix did not reveal any additional cTnT bands (results not shown). 


\section{Chapter 5}

\section{$\underset{(\text { LAb M7) }}{\text { Lysates cTnT tachypacing }}$}

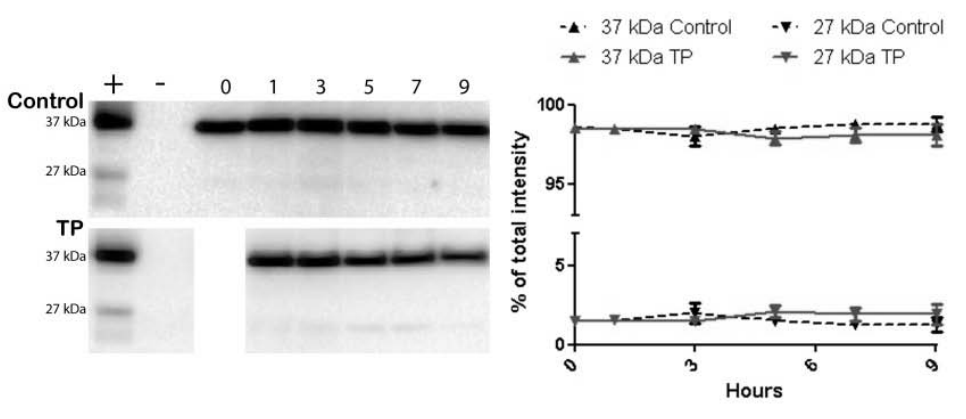

\section{Lysates cTnT tachypacing \\ (mAb mix)}

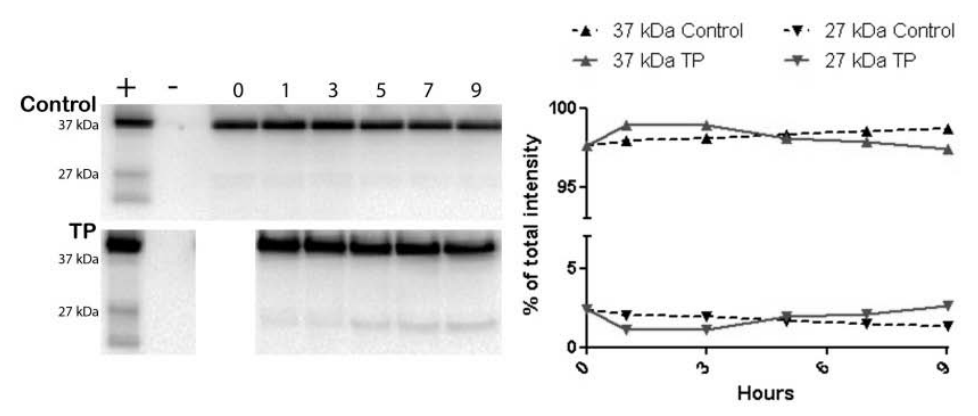

Figure 11: Western blots of tachypaced cell culture lysates probed for cTnT. The upper part shows the blot and the intensity quantification after probing with the M7 mAb from the elecsys kit. The lower part show the results for probing with the cTnT antibody mix.

\section{Media cTnT tachypacing}

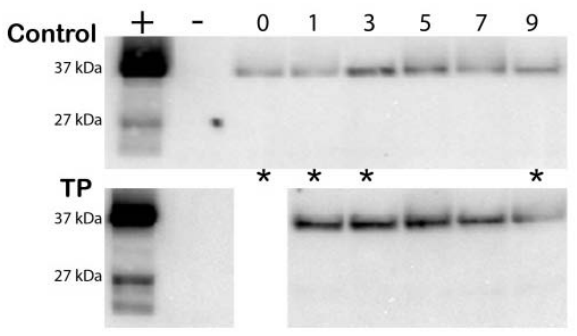

Figure 12: Western blot of tachypaced cell culture media probed for cTnT (probed with M7 $\mathrm{mAb}) .{ }^{*}$ Control 0, 1, 3 and 9 had cTnT concentrations of $0.183,0.023$, 0.074 and $0.171 \mu \mathrm{g} / \mathrm{L}$, respectively. 


\section{Discussion}

In this pilot-study, we explored the release of cTnT and cTnI from cultured HL-1 cardiomyocytes in response to simulated ischemia and rapid electric field stimulation at $3 \mathrm{~Hz}$ (tachypacing). Our results show (1) that the cellular content of cTnI and cTnT decreases strongly in response to ischemia. After 3 hours of ischemia, the cTnI content has dropped by over $50 \%$ and the cTnT content by over $20 \%$. This decrease is a) not associated with a decrease in the cellular content of LDH and b) not accompanied by a release of the cTns into the culture medium. After more than 3 hours of ischemia treatment, the cellular levels of LDH also begin to drop and cTnI, cTnT and LDH get released into the culture medium.

Upon tachypacing, the cellular decrease of LDH begins after 3 hours, but in the first hour of pacing, the cardiomyocytes had already lost $37 \%$ and $21 \%$ of their $\mathrm{cTnI}$ and cTnT content, respectively. (2) Upon ischemia the cTnI content in the cells and the release into the culture medium is more pronounced than for cTnT. This results in a relative increase in the cellular content of cTnT versus cTnI (i.e. a 16 fold increase after 24 hours of ischemia). Upon tachypacing we do not find marked changes in the relative cellular contents of cTnT and cTnI. Moreover, the release of LDH from the tachypaced cells begins slightly earlier, but proceeds more gradually than in the ischemia treated cells. (3) Ischemia induced the formation of fragmented forms of cTnT and cTnI in the cell lysates, tachypacing does not. However, within the culture medium, only the intact forms of cTnI and cTnT could be detected (both after ischemia and tachypacing).

The release characteristic of $\mathrm{cTnI}$ and $\mathrm{cTnT}$ from the cells in response to ischemia are comparable to those seen after AMI. Following an AMI, the release kinetics of cTnT and cTnI are roughly similar and concentrations begin to rise 3-6 hours after the onset of AMI and peak after 12-24 hours. ${ }^{31}, 32$ Similarly the HL-1 cells begin releasing CTnI and cTnT 3 to 5 hours after inducing ischemia. This release was associated with a concomitant release of LDH. As the release of LDH is associated with a loss of membrane integrity and commonly used to quantify cell death, 22, 27 its simultaneous release with cTn suggests that the cTn release in this study only occurs from irreversibly damaged cardiomyocytes.

Before the cTns are release into the medium, however, we already detect a significant decrease in their cellular content. Importantly, the cellular levels of LDH 
do not decrease during this period, suggesting that cTnI and cTnT are lost intracellularly, before the onset of irreversible cell-death. This decrease is (at least in part) due to the intracellular degradation of the cTns. This is best illustrated by the Western Blot results for cTnI (figure 3), where we find a dynamic change in the detected forms of cTnI in response to the ischemia treatment. This change was not detectable by the detector antibodies from the cTnI-assay, so the assay does not detect all the cTnI that is present within the cells. For cTnT, we also find evidence of a specific proteolytic breakdown (figure 5), but there is no clear difference between the molecular forms detected by the detector antibody from the cTnTassay and the cTnT specific antibody mix. The lower molecular weight immunoreactive bands of cTnI and cTnT are, however, only detectable on the blot several hours after the decrease in the cellar concentrations. Therefore, it is likely that the decrease in response to ischemia might also be the result of other degradation processes (specific or non-specific) or other post-translations modifications, such as phosphorylation ${ }^{33}$ and ubiquitination. ${ }^{34,35}$

Irrespective of the exact underlying mechanism for the intracellular decrease, the decreased recovery suggests that the released cTns represent only a relatively small part of the total amount of cTn that was originally present in the cardiomyocytes. Other in vitro experiments, using neonatal rat cardiomyocytes even showed a slightly lower recovery of 34\% for cTnI and 39\% for cTnT in response to 24 hours of metabolic inhibition. ${ }^{22}$ In vivo, the lower recovery may even be more pronounced and earlier reports have shown that after 72 hours after AMI only about $5 \%$ of cTnT is recovered (in comparison to the recovery of cytoplasmic enzymes like LDH). ${ }^{36}$ The decreased (and possible stimulus dependent) differences in the recovery of the cTns may have consequences for their use in infarct size quantification. Although released cTn levels correlate with the infarct size ${ }^{37}$, the cytosolic enzymes such as LDH, and hydroxybutyrate dehydrogenase (HBDH) and Creatine Kinase (CK) allow for a better quantification of infarct size ${ }^{36}$. In particular in conditions where infarct onset is known CK outperforms cTn with respect to infarct size quantification. ${ }^{38}$

In our study we find some interesting differences in the cellular fate and the release characteristics between cTnI and cTnT. For example, the cellular decrease of cTnI strongly exceeds that of cTnT. Moreover, we find a more pronounced increase in 
cTnI medium levels in the early hours after the onset of ischemia than for cTnT (figure $2 \mathrm{~b}$ and $2 \mathrm{~d}$ ). A possible explanation could be the fact that $\mathrm{cTnI}$ is located outermost on the thin filament, ${ }^{39}$ which may facilitate a more readily access to proteases such as caspase ${ }^{16,17}$ and calpain. ${ }^{18-20}$ The less pronounced cellular decrease (and medium increase) of cTnT compared to cTnI could additionally be caused by the fact that cTnT, in itself, can bind to tropomyosin with high affinity. ${ }^{40}$, ${ }^{41}$ This would also offer an explanation for the fact that the maximum cTnT release is also lower than that of $\mathrm{cTnI}$ and $\mathrm{LDH}$.

The above described observation that $\mathrm{cTnT}$ remains in the cell lysates longer than cTnI and LDH does not hold true in the tachypaced cells. When comparing figure $2 \mathrm{f}$ and $4 \mathrm{f}$ it is clear that upon tachypacing there is almost no increase in the relative amount of cTnT compared to cTnI in the cell lysates. Moreover, the decrease in cTnI and cTnT, seen during the first hour of tachypacing, is not associated with a change in the relative amounts of cTn degradation products. This result is in line with a previous study by Ke et al. ${ }^{19}$ who have shown a gradual decrease in the cTn content in HL-1 cardiomyocytes that were subject to $3 \mathrm{~Hz}$ tachypacing, but also failed to detect a specific degradation product. This suggest that the decrease in the cTns may be caused by different post-translational modifications compared to those after ischemia. It has, for example been shown that ischemia can induce a specific degradation of $\mathrm{cTnT}^{42}$ and that electrical pacing can induce (via protein kinase D1) the phosphorylation of cTnI.43

With respect to the release of cTn into the medium, we could not detect the presence of degraded forms of cTnI or cTnT in the culture medium in either ischemia or tachypacing treated cells. This was unexpected, in particular for the ischemia experiment because the cell lysates did show low MW band on the WB. Moreover, several studies have shown the presence of fragmented forms of $\mathrm{cTn}$ in human serum after AMI. ${ }^{44}$, 45 Moreover, studies in neonatal rat cardiomyocytes have shown the release of both intact and fragmented forms of cTnI and cTnT in response to metabolic inhibition..$^{22}$ There are several possible explanations for the fact that we do not detect the cTn fragments in the culture medium. First, it could be that $\mathrm{cTnT}$ and $\mathrm{CTnI}$ are only released in the intact form and that any subsequent degradation, as in described in human serum after AMI, ${ }^{44,}{ }^{45}$ may be caused by breakdown in the bloodstream. Secondly, it could be that the methods used in our 
study are not sensitive enough to accurately detect the fragmented cTn forms. For example, the antibodies from the axsym cTnI kit failed to detect fragments of cTnI that were detectable by a mix of 3 anti-cTnT mAbs. As we performed an IP for cTnI and cTnT with only one specific antibody (or two for the cTnI IP), it could even be that fragmented forms of cTn are lost because the mAbs used in the IP do not pick them up. Importantly, we used the same "catcher" antibodies as those from the assays used to measure the cTn concentrations and our IP was able to extract over $95 \%$ of the cTn in the medium samples. So our IP extracts virtually all the troponin that is measured by the assays. More in general, a visual inspection of the media blots reveals a relatively low signal intensity in general, and the pre-IP cTnI and cTnT concentrations may have been too low to accurately detect small amounts of cTn degradation products. Perhaps IP using beads with several anti cTn mAbs, directed towards different parts of the cTn protein could improve the sensitivity and enable the detection of fragmented forms of cTn in the medium.

In this study we found that the actual release of cTn from the cells into the medium in response to tachypacing was always associated with a concomitant release of LDH. It has however been hypothesized that the concomitant release of LDH with the cTns is not necessarily the result of irreversible cellular damage. Recently, Hickman et al. ${ }^{46}$ offered an interesting explanation for the release of cTn from viable, non-necrotic cardiomyocytes. According to their hypothesis, blebs can form on the plasma membrane of cardiomyocytes in response to ischemia. These blebs, can either be reabsorbed, or release their content into the circulation. When the blebs release their content, cTn levels in a patient's blood will rise, whilst the cardiomyocytes remain viable (if the ischemic damage is not too large). If this hypothesis is correct, than the concomitant release of LDH with the cTns is not necessarily the result of irreversible cellular damage. Future (morphological) studies, using electron microscopy are needed to investigate the presence or absence of membrane blebbing under various experimental conditions. Moreover, future studies should also investigate the mechanism underlying the intracellular decrease of cTnI and cTnT in the time before LDH is released. The studies should not only investigate the cellular fate in more details, i.e. by studying if the decrease of the cTns is related to proteolytic breakdown, phosphorylation or 
ubiquitinilation, but also the functional effects of these modifications on contractility and viability of cardiomyocytes.

\section{Acknowledgements}

This study was partly funded by the E.C. Noyons foundation (E.C Noyons Stichting ter Bevordering van de Klinische Chemie in Nederland).

\section{References}

1. Alpert JS, Thygesen K, Antman E, Bassand JP. Myocardial infarction redefined--a consensus document of the joint european society of cardiology/american college of cardiology committee for the redefinition of myocardial infarction. J Am Coll Cardiol. 2000;36:959-969

2. Morrow DA, Cannon CP, Jesse RL, Newby LK, Ravkilde J, Storrow AB, Wu AH, Christenson RH. National academy of clinical biochemistry laboratory medicine practice guidelines: Clinical characteristics and utilization of biochemical markers in acute coronary syndromes. Circulation. 2007;115:e356-375

3. Hamm CW, Giannitsis E, Katus HA. Cardiac troponin elevations in patients without acute coronary syndrome. Circulation. 2002;106:2871-2872

4. Kelley WE, Januzzi JL, Christenson RH. Increases of cardiac troponin in conditions other than acute coronary syndrome and heart failure. Clin Chem. 2009

5. Scharhag J, Herrmann M, Urhausen A, Haschke M, Herrmann W, Kindermann W. Independent elevations of n-terminal pro-brain natriuretic peptide and cardiac troponins in endurance athletes after prolonged strenuous exercise. Am Heart J. 2005;150:1128-1134

6. Kratz A, Lewandrowski KB, Siegel AJ, Chun KY, Flood JG, Van Cott EM, Lee-Lewandrowski E. Effect of marathon running on hematologic and biochemical laboratory parameters, including cardiac markers. Am J Clin Pathol. 2002;118:856-863

7. Fortescue EB, Shin AY, Greenes DS, Mannix RC, Agarwal S, Feldman BJ, Shah MI, Rifai N, Landzberg MJ, Newburger JW, Almond CS. Cardiac troponin increases among runners in the boston marathon. Ann Emerg Med. 2007;49:137-143, 143 e131

8. Leers MP, Schepers R, Baumgarten R. Effects of a long-distance run on cardiac markers in healthy athletes. Clin Chem Lab Med. 2006;44:999-1003

9. Michielsen EC, Wodzig WK, Van Dieijen-Visser MP. Cardiac troponin $t$ release after prolonged strenuous exercise - a review. Sports Med. 2008;38:425-435

10. Mingels A, Jacobs L, Michielsen E, Swaanenburg J, Wodzig W, van Dieijen-Visser M. Reference population and marathon runner sera assessed by highly sensitive cardiac troponin $t$ and commercial cardiac troponin $t$ and $i$ assays. Clin Chem. 2009;55:101-108

11. Neumayr G, Pfister R, Mitterbauer G, Maurer A, Gaenzer H, Sturm W, Hoertnagl H. Effect of the "race across the alps" in elite cyclists on plasma cardiac troponins i and t. Am J Cardiol. 2002;89:484486

12. Shave R, George K, Gaze D. The influence of exercise upon cardiac biomarkers: A practical guide for clinicians and scientists. Curr Med Chem. 2007;14:1427-1436

13. Middleton N, George K, Whyte G, Gaze D, Collinson P, Shave R. Cardiac troponin t release is stimulated by endurance exercise in healthy humans. J Am Coll Cardiol. 2008;52:1813-1814

14. Remppis A, Scheffold T, Greten J, Haass M, Greten T, Kubler W, Katus HA. Intracellular compartmentation of troponin $\mathrm{t}$ : Release kinetics after global ischemia and calcium paradox in the isolated perfused rat heart. J Mol Cell Cardiol. 1995;27:793-803 
15. Neumayr G, Pfister R, Mitterbauer G, Eibl G, Hoertnagl H. Effect of competitive marathon cycling on plasma n-terminal pro-brain natriuretic peptide and cardiac troponin $t$ in healthy recreational cyclists. Am J Cardiol. 2005;96:732-735

16. Lancel S, Joulin O, Favory R, Goossens JF, Kluza J, Chopin C, Formstecher P, Marchetti P, Neviere R. Ventricular myocyte caspases are directly responsible for endotoxin-induced cardiac dysfunction. Circulation. 2005;111:2596-2604

17. Communal C, Sumandea M, de Tombe P, Narula J, Solaro RJ, Hajjar RJ. Functional consequences of caspase activation in cardiac myocytes. Proc Natl Acad Sci U S A. 2002;99:6252-6256.

18. Barta J, Toth A, Edes I, Vaszily M, Papp JG, Varro A, Papp Z. Calpain-1-sensitive myofibrillar proteins of the human myocardium. Mol Cell Biochem. 2005;278:1-8

19. Ke L, Qi XY, Dijkhuis AJ, Chartier D, Nattel S, Henning RH, Kampinga HH, Brundel BJ. Calpain mediates cardiac troponin degradation and contractile dysfunction in atrial fibrillation. J Mol Cell Cardiol. 2008;45:685-693

20. Kositprapa C, Zhang B, Berger S, Canty JM, Jr., Lee TC. Calpain-mediated proteolytic cleavage of troponin i induced by hypoxia or metabolic inhibition in cultured neonatal cardiomyocytes. $\mathrm{Mol}$ Cell Biochem. 2000;214:47-55

21. Hessel MH, Atsma DE, van der Valk EJ, Bax WH, Schalij MJ, van der Laarse A. Release of cardiac troponin i from viable cardiomyocytes is mediated by integrin stimulation. Pflugers Arch. 2008;455:979-986

22. Hessel MH, Michielsen EC, Atsma DE, Schalij MJ, van der Valk EJ, Bax WH, Hermens WT, van Dieijen-Visser MP, van der Laarse A. Release kinetics of intact and degraded troponin $\mathrm{i}$ and $\mathrm{t}$ after irreversible cell damage. Exp Mol Pathol. 2008

23. Feng J, Schaus BJ, Fallavollita JA, Lee TC, Canty JM, Jr. Preload induces troponin i degradation independently of myocardial ischemia. Circulation. 2001;103:2035-2037.

24. Zhang Z, Biesiadecki BJ, Jin JP. Selective deletion of the nh2-terminal variable region of cardiac troponin $\mathrm{t}$ in ischemia reperfusion by myofibril-associated mu-calpain cleavage. Biochemistry. 2006;45:11681-11694

25. Feng HZ, Biesiadecki BJ, Yu ZB, Hossain MM, Jin JP. Restricted n-terminal truncation of cardiac troponin $\mathrm{t}$ : A novel mechanism for functional adaptation to energetic crisis. J Physiol. 2008

26. Claycomb WC, Lanson NA, Jr., Stallworth BS, Egeland DB, Delcarpio JB, Bahinski A, Izzo NJ, Jr. Hl-1 cells: A cardiac muscle cell line that contracts and retains phenotypic characteristics of the adult cardiomyocyte. Proc Natl Acad Sci U S A. 1998;95:2979-2984

27. Seymour EM, Wu SY, Kovach MA, Romano MA, Traynor JR, Claycomb WC, Bolling SF. Hl-1 myocytes exhibit pkc and k(atp) channel-dependent delta opioid preconditioning. J Surg Res. 2003;114:187-194

28. Schwenk RW, Dirkx E, Coumans WA, Bonen A, Klip A, Glatz JF, Luiken JJ. Requirement for distinct vesicle-associated membrane proteins in insulin- and amp-activated protein kinase (ampk)-induced translocation of glut4 and cd36 in cultured cardiomyocytes. Diabetologia. 2010;53:2209-2219

29. Claycomb WC, Lanson NA, Jr., Stallworth BS, Egeland DB, Delcarpio JB, Bahinski A, Izzo NJ, Jr. Hl-1 cells: A cardiac muscle cell line that contracts and retains phenotypic characteristics of the adult cardiomyocyte. Proceedings of the National Academy of Sciences of the United States of America. 1998;95:2979-2984

30. Michielsen EC, Diris JH, Hackeng CM, Wodzig WK, Van Dieijen-Visser MP. Highly sensitive immunoprecipitation method for extracting and concentrating low-abundance proteins from human serum. Clin Chem. 2005;51:222-224

31. Januzzi JL. Cardiac biomarkers in clinical practice. Sudbury, Mass.: Jones and Bartlett Publishers; 2011.

32. Collinson PO. Troponin t or troponin i or ck-mb (or none?). Eur Heart J. 1998;19 Suppl N:N16-24

33. Jideama NM, Noland TA, Jr., Raynor RL, Blobe GC, Fabbro D, Kazanietz MG, Blumberg PM, Hannun YA, Kuo JF. Phosphorylation specificities of protein kinase c isozymes for bovine cardiac 
troponin $\mathrm{i}$ and troponin $\mathrm{t}$ and sites within these proteins and regulation of myofilament properties. J Biol Chem. 1996;271:23277-23283

34. Kedar V, McDonough H, Arya R, Li HH, Rockman HA, Patterson C. Muscle-specific ring finger 1 is a bona fide ubiquitin ligase that degrades cardiac troponin i. Proceedings of the National Academy of Sciences of the United States of America. 2004;101:18135-18140

35. Witt SH, Granzier H, Witt CC, Labeit S. Murf-1 and murf-2 target a specific subset of myofibrillar proteins redundantly: Towards understanding murf-dependent muscle ubiquitination. Journal of molecular biology. 2005;350:713-722

36. Kragten JA, Hermens WT, van Dieijen-Visser MP. Cardiac troponin $t$ release into plasma after acute myocardial infarction: Only fractional recovery compared with enzymes. Ann Clin Biochem. 1996;33 ( Pt 4):314-323

37. Steen H, Giannitsis E, Futterer S, Merten C, Juenger C, Katus HA. Cardiac troponin $t$ at 96 hours after acute myocardial infarction correlates with infarct size and cardiac function. J Am Coll Cardiol. 2006;48:2192-2194

38. Hage FG, Aqel R, Aljaroudi W, Heo J, Pothineni K, Hansalia S, Lawson D, Dubovsky E, Iskandrian AE. Correlation between serum cardiac markers and myocardial infarct size quantified by myocardial perfusion imaging in patients with hypertrophic cardiomyopathy after alcohol septal ablation. The American journal of cardiology. 2010;105:261-266

39. Toyo-Oka T, Ross J, Jr. Ca2+ sensitivity change and troponin loss in cardiac natural actomyosin after coronary occlusion. The American journal of physiology. 1981;240:H704-708

40. Feng HZ, Hossain MM, Huang XP, Jin JP. Myofilament incorporation determines the stoichiometry of troponin i in transgenic expression and the rescue of a null mutation. Archives of biochemistry and biophysics. 2009;487:36-41

41. Perry SV. Troponin t: Genetics, properties and function. J Muscle Res Cell Motil. 1998;19:575-602

42. Feng HZ, Chen M, Weinstein LS, Jin JP. Removal of the n-terminal extension of cardiac troponin $\mathrm{i}$ as a functional compensation for impaired myocardial beta-adrenergic signaling. J Biol Chem. 2008;283:33384-33393

43. Goodall MH, Wardlow RD, 2nd, Goldblum RR, Ziman A, Lederer WJ, Randall W, Rogers TB. Novel function of cardiac protein kinase $\mathrm{d} 1$ as a dynamic regulator of ca2+ sensitivity of contraction. The Journal of biological chemistry. 2010;285:41686-41700

44. Michielsen EC, Diris JH, Kleijnen VW, Wodzig WK, Van Dieijen-Visser MP. Investigation of release and degradation of cardiac troponin $\mathrm{t}$ in patients with acute myocardial infarction. Clin Biochem. 2007;40:851-855

45. Madsen LH, Christensen G, Lund T, Serebruany VL, Granger CB, Hoen I, Grieg Z, Alexander JH, Jaffe AS, Van Eyk JE, Atar D. Time course of degradation of cardiac troponin i in patients with acute st-elevation myocardial infarction. The assent-2 troponin substudy. Circ Res. 2006;99:11411147

46. Hickman PE, Potter JM, Aroney C, Koerbin G, Southcott E, Wu AH, Roberts MS. Cardiac troponin may be released by ischemia alone, without necrosis. Clinica chimica acta; international journal of clinical chemistry. 2010;411:318-323 



\title{
CHAPTER 6
}

\section{Inflammation, overhydration and cardiac biomarkers in haemodialysis patients: a longitudinal study}

\begin{abstract}
SUMMARY
Background: Inflammation, overhydration and elevated cardiac biomarkers are related to outcome in haemodialysis (HD) patients. Here, we explored the relationship between the body composition, inflammation and cardiac biomarker concentrations in HD patients longitudinally.

Methods: 44 HD patients were followed for 6 months. Body composition was assessed by multifrequency bioimpedance (BIA). Serum concentrations of cardiac troponin $T$ (cTnT), high-sensitive C-reactive protein (hsCRP), brain natriuretic peptide (BNP) and $N$ terminal proBNP (NT-proBNP) were assessed at 2 monthly intervals. The longitudinal data analysis was conducted with a marginal model.

Results: During the follow-up, the parameters describing the body composition were highly predictive of both BNP and NT-proBNP and independent of gender, time, hsCRP and $c T n T$ concentrations. The intracellular water (ICW)/body weight (BW) ratio (reflecting malnutrition) exerted a negative effect, whereas the extracellular water (ECW)/BW ratio (reflecting overhydration) had a positive effect on BNP and NT-proBNP concentrations. HsCRP and cTnT concentrations were significantly associated with each other. Furthermore NT-proBNP concentrations were predictive of $c T n T$ and hsCRP concentrations.

Conclusions: In the present study we find a significant relation between BIA derived body composition parameters and natriuretic peptide concentrations. This relationship was independent of the cardiac history of the patient and suggests that the natriuretic peptide levels are to some degree modifiable by changing a patient's fluid distribution. Moreover, cTnT, BNP, NT-proBNP and hsCRP were significantly related, showing a complex relation between overhydration, malnutrition, inflammation, and cardiac biomarkers in dialysis patients.
\end{abstract}




\section{Introduction}

In dialysis patients, various risk markers for the vastly increased mortality risk have emerged. Among them both parameters related to abnormalities in body composition (fluid distribution) ${ }^{1-3}$ and various biochemical markers, such as such C-reactive protein $(\mathrm{CRP})$, cardiac troponin $\mathrm{T}(\mathrm{cTnT})$, brain natriuretic peptide (BNP) and N-terminal proBNP (NT-proBNP) were shown to be powerful predictors of mortality. ${ }^{4-6}$

While the predictive power of these parameters has clearly been shown, they represent different biological processes. High sensitive CRP (hsCRP) is thought to reflect inflammation, (NT-pro)BNP concentrations are generally considered to reflect cardiac wall stress, and cTnT concentrations are thought to describe ischemic cardiac damage. While (NT-pro)BNP and cTnT have proven to be accurate and sensitive markers for assessing heart failure and ischaemic cardiac damage, respectively, their levels might additionally be influenced by a decreased renal clearance in patients with severe renal disease. ${ }^{7-9}$ Moreover, cTnT may be elevated due to increased cardiac wall stress leading to micro-ischemia, as reflected by the relation between left ventricle hypertrophy $(\mathrm{LVH})$ and cTnT concentrations in haemodialysis patients. ${ }^{10,} 11$ Finally, elevated cTnT concentrations in dialysis patients have also been associated with inflammation and are possibly related to endothelial damage and an increase in oxidative stress. ${ }^{12,}{ }^{13}$ Hence, for subjects with renal failure, a clear-cut delimitation of the biomarker's individual functions and their apparent interdependence are seemingly more intricate. Empirical evidence so far suggests that their already known and established biological roles may also be affected by a dysfunctional state of the dialysis patient's body composition status.

The parameters describing the body composition (BC), such as the amount of intracellular $(\mathrm{ICW})$ or extracellular water $(\mathrm{ECW})$ have been linked to varying underlying causes. ICW is often used to estimate the body cell mass (BCM) and as such, reflects nutritional status and ECW has been shown to reflect overhydration. ${ }^{14}$ Over the years several approaches using bioelectrical impedance (BIA) measurements in haemodialysis (HD) patients have been described to accurately assess volume distributions. ${ }^{15,16}$ 
To date, few studies have assessed the relationship between the body composition and cardiac and inflammatory biomarkers. In two recent studies, overhydration was found to be related to inflammation, as reflected by a relation between extracellular volume (or inferior caval vein diameter) and CRP concentrations. ${ }^{17,18}$ Although the mechanism behind the relation between overhydration and inflammation has not yet been elucidated, an increased passage of endotoxins from the intestines into the blood due to gut edema might be involved. ${ }^{19}$ Another explanation might be a reduction in 'dry weight' because of loss of body cell mass in the inflammatory state, which leads to progressive overhydration if changes in dry weight are not appropriately detected and treated. ${ }^{20,21}$ More recently, a relation between overhydration, NT-proBNP and cTnT has been suggested. ${ }^{22}$ Mechanistically, an increase in ECW might induce left ventricular dilatation and subsequent increases in NT-proBNP (and cTnT) concentrations.

Focus of the present study is the relationship between cardiac and inflammation biomarkers and abnormalities in body fluid distribution, as characteristically found in dialysis patients. While a few studies have assessed these interrelations to the best of our knowledge no study as yet assessed these relations in a longitudinal way.

\section{Patients and methods}

\section{Study design}

The study consisted of both a cross-sectional and a longitudinal part. Patients were studied for 6 consecutive months. Blood samples were collected pre-dialysis at the start of the study and subsequently every two months for a period of 6 months. Bioimpedance measurements were performed on the same day as blood sampling.

\section{Patients}

A cohort of 44 chronic haemodialysis patients participated in this 6-month longitudinal study. The study protocol was approved by the medical ethical review committee of the University Hospital Maastricht. All patients provided written informed consent. Exclusion criteria were: the presence of a pacemaker or an internal cardioverter defibrillator (ICD). Blood samples were collected pre- 
dialysis at the start of the study and subsequently every two months for a period of 6 months. Collected plasma and serum samples were stored at $-80{ }^{\circ} \mathrm{C}$ until analysis. Haemodialysis treatment was performed with the Polyflux $8 \mathrm{~L}^{\circledR}$ in 39 patients, Sureflux 130 Nipro $^{\circledR}$ in 3 patients, and 2 patients were treated with on-line haemodiafiltration. Vascular access was achieved through a native fistula in 28 patients, by PTFE graft in 14 patients and by central venous catheter in 2 patients. In total, 12 patients suffered an event (an acute worsening in the patient's condition, which required hospitalisation). Reasons for the events were very diverse, (i.e. ranging from pneumonia to hip replacement) which prevented a clear analysis of the acute effects of the event and data gathered during an event were not included in our analysis. To investigate (and correct) possible differences between the event and event-free patients, the occurrence of an event during the study was included into the marginal model.

Patients could further be divided into two groups on the basis of a history of cardiovascular disease (CVD). CVD was considered present when patients had a history of myocardial infarction, had required coronary intervention (e.g. percutaneous transluminal coronary angioplasty (PTCA), Coronary Artery Bypass Grafting (CABG)) or suffered from congestive cardiac failure.

\section{Laboratory analysis}

C-reactive protein (CRP) concentrations were measured using the CardioPhase hsCRP assay (Dade Behring Inc., Newark, USA). According to the manufacturer's protocol the limit of detection (LOD) of the assay is $0.175 \mathrm{mg} / \mathrm{L}$ and the coefficient of variation $(\mathrm{CV})$ is $<10 \%$ for concentrations between $0.5 \mathrm{mg} / \mathrm{L}$ and $62 \mathrm{mg} / \mathrm{L}$. HsCRP concentrations $>3 \mathrm{mg} / \mathrm{L}$ were considered elevated. CTnT was measured on the Elecsys 2010 (Roche Diagnostics, Mannheim, Germany) using a pre-commercial high-sensitive cTnT (hs-cTnT) assay. Precision profiles for this assay were established in our laboratory and the 99th percentile reference cut-off value was determined in a population of 501 healthy subjects. ${ }^{23}$ The LOD for the hs-cTnT assay was established at $<0.001 \mu \mathrm{g} / \mathrm{L}$ and the $10 \% \mathrm{CV}$ cut-off concentration was $0.009 \mu \mathrm{g} / \mathrm{L}$. The 99th percentile was established at $0.016 \mu \mathrm{g} / \mathrm{L}$. CTnT concentrations above the 99th percentile measured in the healthy reference population were considered elevated (as recommended in recent NACB guidelines). ${ }^{24}$ NT-proBNP 
was measured using the proBNP assay for the Elecsys 2010. According to the package insert the LOD is $0.6 \mathrm{pmol} / \mathrm{L}$ and the $\mathrm{CV}$ at $20.7 \mathrm{pmol} / \mathrm{L}$ is $3.2 \%$ and is $2.3 \%$ at $586 \mathrm{pmol} / \mathrm{L}$. Elevated NT-proBNP concentrations were defined as values above the 99th percentile measured in a reference population of 501 healthy subjects (unpublished results). The 99th percentile value was found to be $31.28 \mathrm{pmol} / \mathrm{L}$ for the male- and $35.55 \mathrm{pmol} / \mathrm{L}$ for the female participants. BNP was measured in plasma with the SHIONORIA BNP immunoradiometric assay (Cis-Bio International, Gif-sur-Yvette, France). This kit, according to its package insert, has a LOD of $2.0 \mathrm{pg} / \mathrm{mL}$ en a within- and between-run $\mathrm{CV}$ of $2.7 \%$ and $4.3 \%$ at 22.1 $\mathrm{pg} / \mathrm{mL}$ and $21.1 \mathrm{pg} / \mathrm{mL}$ respectively $(1 \mathrm{pg} / \mathrm{mL}=0.289 \mathrm{pmol} / \mathrm{L})$. BNP concentrations above the $95 \%$ confidence interval are considered elevated. According to the package insert this value is $18.4 \mathrm{pg} / \mathrm{mL}(18.6 \mathrm{pg} / \mathrm{mL}$ for women and $18.2 \mathrm{pg} / \mathrm{mL}$ for men). Blood samples were taken before dialysis, in order to prevent possible influences of the dialysis process itself on the concentrations of the different biomarkers. ${ }^{13,25}$

\section{Bioimpedance analysis}

Body composition, described as extracellular water (ECW), and intracellular water (ICW) was assessed by multifrequency bioimpedance (BIA) measurements (Xitron 4002 Hydra), as described previously. ${ }^{15,16,26}$ For each BIA measurement pre- and post-dialytic values of ECW and ICW were measured and reported. Additional parameters used to asses the volume and nutritional status were also recorded, among them: the ICW:body weight ratio (ICW:BW) and the ECW:body weight ratio $(\mathrm{ECW}: \mathrm{BW})$. Furthermore, the phase angle $(\mathrm{PA})$, which is related to the ratio between ICW and ECW, and is thought to represent cellular membrane integrity, ${ }^{27}$ is recorded. Briefly, the BIA device measures the overall opposition, the impedance, to an alternating and/or direct electrical current. The impedance is the resultant of 2 components, the resistance and the capacitive reactance. So, the impedance is the vector that can be drawn from the resistance and the reactance. PA is the angle between the impedance and resistance vectors. The resistance represents the restriction to the flow of an electrical current through the body and it is associated with the amount of water present in the tissues. The capacitive reactance represents the opposition encountered by the current as a result of the 
capacitate function of tissue interfaces and cell membranes. ${ }^{27,} 28$ Note that the PA thus depends on both the amount of tissue hydration and the amount of intact cellmembranes.

In subsequent calculations we used the BIA-derived parameters that were gathered post-dialysis. This was done because volume state after dialysis is less variable as compared to pre-dialytic values. In addition to bioimpedance analysis, both preand post dialytic blood pressures (taken 5 minutes after the end of dialysis) were recorded.

\section{Statistics}

Data analyses were performed using Statistical Package for Social Sciences (SPSS), Version 15.0 for Windows (SPSS Inc., Chicago, IL, USA). To accommodate the longitudinal nature of the data and investigate whether the biomarker concentrations changed over time, a marginal model was fit. All outcome parameters (either cardiac or inflammation biomarkers) showed a skewed distribution, the reason for which they were log transformed (ln). Main determinants were the Body Composition (BC) parameters and the biomarkers themselves. Multivariable adjustment took place for a number of additional covariates, namely: gender, occurrence of an event (hospitalisation), diabetes, time (duration of study), cardiac history, time on dialysis, systolic blood pressure and vascular access (native fistula or PTFE graft). Non-significant predictors were eliminated via the backward procedure, except for gender and event, which were always retained in the model, irrespective of their significance. This was done to warrant adjusted effect of the main determinants for possible gender and/or events confounding. Parameters were estimated via the restricted maximum likelihood (REML) and the significance level was set at 5\%. For those parameters whose pvalues $<0.1$, additional likelihood ratio (LR) tests were carried out, equally at the $5 \%$, to determine whether to retain them in the final model. 


\section{Results}

\section{Patient characteristics at baseline}

Patient characteristics at the start of our study are given in Table 1. Our population consisted of 30 male and 14 female patients with an average ( \pm SD) age of $66( \pm$ 10.50) years. The 44 patients showed a large amount of cardiovascular complications, $55 \%$ of the patients had a history of ischemic cardiac disease and many of our patients showed elevated biomarker concentrations. At baseline, 95\% of the patients showed cTnT concentrations above the AMI cut-off concentration of $0.016 \mu \mathrm{g} / \mathrm{L}(23 \%$ had cTnT concentrations above $0.1 \mu \mathrm{g} / \mathrm{L})$. Natriuretic peptide concentrations were also frequently increased and $91 \%$ and $98 \%$ of our patients had elevated BNP and NT-proBNP concentrations, respectively. In addition, hsCRP concentrations were elevated in $64 \%$ of the patients.

Table 1. Patient characteristics at the start of the study.

\begin{tabular}{|c|c|}
\hline Men & 30 \\
\hline Women & 14 \\
\hline Age (years) & 66 (total range 35-91) \\
\hline Time on dialysis (months) & 30 (total range $1-102$ ) \\
\hline Hypertension & $37(84 \%)$ \\
\hline Diabetes & $15(34 \%)$ \\
\hline History of ischemic heart disease & $14(32 \%)$ \\
\hline History of cardiac failure & $13(30 \%)$ \\
\hline BMI $\left(\mathrm{kg} / \mathrm{m}^{2}\right)$ & $24.4(22.2-26.0)$ \\
\hline hsCRP (mg/L) & $7.0(1.7-15.9)$ \\
\hline Haemoglobin $(\mathrm{mmol} / \mathrm{L})($ mean \pm SD) & $7.0 \pm 0.8$ \\
\hline $\mathrm{cTnT}(\mu \mathrm{g} / \mathrm{L})$ & $0.056(0.036-0.09)$ \\
\hline \multirow[t]{2}{*}{$\mathrm{BNP}(\mathrm{pg} / \mathrm{mL})$} & $82.6(30.1-252.0)$ \\
\hline & 우 $92.2(55.0-244.8)$ \\
\hline \multirow[t]{2}{*}{ NT-proBNP (pmol/L) } & $843.8(362.7-5544.3)$ \\
\hline & 우 1259.5 (218.5-3808.0) \\
\hline \multirow[t]{2}{*}{ Diastolic BP (mm Hg) } & $69 \pm 18$ \\
\hline & + $63 \pm 16$ \\
\hline \multirow[t]{2}{*}{ Systolic BP (mm Hg) } & $135 \pm 35$ \\
\hline & ㅇ $133 \pm 32$ \\
\hline \multirow[t]{2}{*}{ ICW/BW (L/kg) } & $\partial 0.25 \pm 0.05$ \\
\hline & 우 $0.21 \pm 0.03$ \\
\hline \multirow[t]{2}{*}{ ECW/BW (L/kg) } & ð $0.25 \pm 0.04$ \\
\hline & 우 $0.22 \pm 0.04$ \\
\hline \multirow[t]{2}{*}{ Phase angle (degrees) } & ¿ $4.97 \pm 1.50$ \\
\hline & 우 $4.44 \pm 1.24$ \\
\hline
\end{tabular}

The biomarker concentrations are displayed as median (IQR) concentrations.Body composition parameters (ICW/BW, ECW/BW and $\mathrm{PA}$ ) are displayed as mean $\pm \mathrm{SD}$. 


\section{Marginal models}

Cardiac and inflammatory biomarkers were taken as outcome variables individually and their associations with BC parameters and other biomarkers were tested. For all models, likelihood ratio tests confirmed that the unstructured covariance matrix of observations was the most appropriate. As BNP and NTproBNP are strongly correlated (and originate from the same precursor) multicollinearity problems would arise, if both were to be fitted into the model together. Therefore the models were fitted with either BNP or NT-proBNP, never both of them simultaneously. Results are henceforth mainly shown for NTproBNP. Similarly, the PA was found to be strongly associated with the ECW/BW and ICW/BW in a linear fashion (linear regression, averaged over the time points, $\mathrm{PA}=3.44+23.12 \mathrm{ICW} / \mathrm{BW}-17 \mathrm{ECW} / \mathrm{BW}$ with $\left.\mathrm{R}^{2}=0.93\right)$. Accordingly, the models were fitted either with the PA only or ECW/BW and ICW/BW, not with the three of them concurrently. Hereafter, the models fitted with the phase angle will be referred to as PA-approach whereas the models fitted with ECW/BW and ICW/BW are referred to as ICW-ECW approach.

Tables 2-5 present the marginal models' regression coefficients for each biomarker as outcome variable separately. Table 2, with NT-proBNP as outcome, illustrates the results for both approaches (either PA or ICW-ECW), which yielded similar log likelihoods, had the same variables selected via the backward procedure and comparable estimates for the significant main effect. For parsimonious reasons, only the regression coefficients for the PA approach are presented in the other tables.

\section{Time effect}

For virtually all outcome variables, no significant time effect was detected. Thus, no significant time-related trends were observed in the parameters under investigation. The exception was BNP which seemed to be slightly higher at visit 2 and 4 compared to visit 1. 


\section{Body Composition effect}

In general, the $B C$ parameters were highly predictive of both natriuretic peptide levels. As can be seen in tables 2 and 5, the PA and ICW/BW were shown to exert a negative effect, whereas the ECW had a positive effect on the NT-proBNP and BNP concentrations. The effects of the BC on the BNPs were independent of gender, time, and other biomarker levels. Figure 1 illustrates the relationship between the PA and the NT-proBNP concentrations (regression lines are given for each visit separately). It can be seen that as the PA values increase, $\ln (\mathrm{NT}$-proBNP) levels will linearly decrease. The same rate of decrease for all time points, as given by similar regression slopes, indicates that the effect remains constant over all visits.

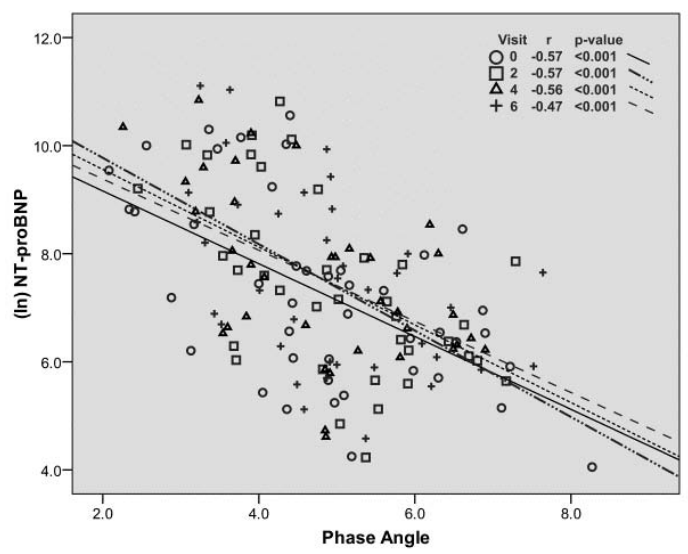

Figure 1. (ln)NT-proBNP concentrations as a function of the phase angle during the 6-month follow-up. Regression lines and correlation coefficients are shown for each of the 4 visits separately.

As can be interpreted from Table 3 and 4, the parameters describing the body composition were not significantly associated with CTnT and hsCRP concentrations, after adjustment for NT-proBNP. However, though omitted, it is noteworthy that, if NT-proBNP was taken out of the multivariable model, strong negative associations between $\mathrm{PA}$ and $\mathrm{CTnT}$ and hsCRP concentrations were detected (parameter estimates -0.104 and -0.306 with adjusted p-values 0.014 and 0.007 , for cTnT and hsCRP, respectively). Similarly, ICW/BW showed a significant negative effect. By contrast, ECW/BW values were significantly predictive neither of cTnT nor hsCRP, even after deletion of NT-proBNP. 
Table 2. Regression parameters estimates and corresponding $95 \%$ confidence intervals (CI) from a marginal model with either the Phase Angle or the ICW-ECW (in italic) approach

\begin{tabular}{lccr}
\hline Variable & $B$ & $\mathbf{9 5 \%} \mathbf{C I}$ & p-value \\
\hline Intercept & 7.67 & $5.93,9.42$ & $<0.001$ \\
& 5.47 & $3.43,7.51$ & $<0.001$ \\
Gender(female) & -0.42 & $-1.18,0.34$ & 0.270 \\
& -0.62 & $-1.45,0.20$ & 0.135 \\
Event (none) & -0.98 & $-1.75,-0.21$ & 0.014 \\
& -1.05 & $-1.83,-0.27$ & 0.010 \\
Cardiac history (none) & -1.12 & $-1.82,-0.42$ & 0.003 \\
& -1.20 & $-1.91,-0.50$ & 0.001 \\
Time on dialysis & 0.01 & $-0.0005,0.029$ & 0.058 \\
& 0.02 & $0.003,0.033$ & 0.019 \\
Systolic BP & 0.005 & $0.001,0.008$ & 0.015 \\
& 0.005 & $0.001,0.009$ & 0.01 \\
(ln) cTnT & 0.48 & $0.24,0.72$ & $<0.001$ \\
& 0.46 & $0.22,0.71$ & $<0.001$ \\
Phase Angle & -0.35 & $-0.53,-0.17$ & $<0.001$ \\
ICW:BW & -4.50 & $-8.98,-0.03$ & 0.049 \\
ECW:BW & 7.07 & $1.68,12.45$ & 0.011 \\
\hline
\end{tabular}

Outcome variable $\ln (\mathrm{NT}$-proBNP). For the categorical variables, the reference group is omitted.

Table 3. Regression parameters

\begin{tabular}{lccl}
\hline Variable & $B$ & $\mathbf{9 5} \% \mathbf{C I}$ & p-value \\
\hline Intercept & 3.16 & $2.84,1.08$ & $<0.001$ \\
Gender & 0.58 & $0.25,0.90$ & 0.001 \\
Event (none) & -0.22 & $-0.55,0.12$ & 0.194 \\
Diabetes & -0.39 & $-0.70,-0.07$ & 0.017 \\
(ln) NT-proBNP & 0.07 & $0.014,0.131$ & 0.016 \\
(ln) hsCRP & 0.06 & $0.013,0.113$ & 0.015 \\
\hline
\end{tabular}

Outcome variable $\ln (\mathrm{cTnT})$

\section{Other covariates}

No gender related differences were observed, except for cTnT, which was significantly lower in the female subjects. NT-proBNP and BNP concentrations were significantly higher in patients who had a history of cardiovascular disease whereas for cTnT and hsCRP no cardiac history effect was observed (Tables 2-5). The patients who had suffered a clinical event during our study had similar cTnT and hsCRP concentrations as those who did not suffer from an event. We did find that non-event patients had, on average lower natriuretic peptide levels. Vascular access was only significantly predictive for hsCRP concentrations, which were 
lowest when vascular access was achieved by PTFE graft. Finally, both higher systolic blood pressure and the longer time on dialysis were predictive of increased NT-proBNP concentrations.

Table 4. Regression parameters

\begin{tabular}{lccl}
\hline Variable & $B$ & $\mathbf{9 5 \%} \mathbf{C I}$ & p-value \\
\hline Intercept & -2.45 & $-4.29,-0.60$ & 0.010 \\
Gender & -0.53 & $-1.25,0.19$ & 0.142 \\
Event (none) & 0.19 & $-0.51,0.89$ & 0.582 \\
Diabetes & 0.60 & $-0.06,1.27$ & 0.074 \\
Vascular acces (PTFE graft) & -0.90 & $-1.60,-0.19$ & 0.014 \\
$(\ln )$ NT-proBNP & 0.29 & $0.12,0.46$ & 0.001 \\
$(\ln )$ cTnT & 0.53 & $0.18,0.88$ & 0.004 \\
& & & \\
\hline
\end{tabular}

Outcome variable $\ln (C R P)$
Table 5. Regression parameters

\begin{tabular}{lccl}
\hline Variable & $B$ & $\mathbf{9 5 \%} \mathbf{C I}$ & p-value \\
\hline Intercept & 7.65 & $6.52,8.77$ & $<0.001$ \\
Gender & 0.19 & $-0.51,0.90$ & 0.583 \\
Event (none) & -0.43 & $-1.16,0.29$ & 0.233 \\
Cardiac history (none) & -0.68 & $-1.35,-0.01$ & 0.047 \\
Phase angle & -0.56 & $-0.73,-0.38$ & $<0.001$ \\
visit 2 & 0.30 & $0.11,0.50$ & 0.003 \\
Visit 4 & 0.33 & $0.12,0.54$ & 0.003 \\
Visit 6 & 0.15 & $-0.12,0.42$ & 0.269 \\
\hline
\end{tabular}

Outcome variable $\ln (B N P)$

\section{Discussion}

The main findings of the present study are the significant relation between the BIA-derived parameters describing body composition and natriuretic peptides, and the relation between inflammation and cardiac biomarkers.

Earlier studies showed equivocal results with regard to the relation between volume status and (NT-pro)BNP concentrations.22, 29 This is likely due to the fact that elevated concentrations of BNP indirectly reflect overhydration due to left ventricular dilatation, whereas intrinsic cardiac disease may have the same effect. In the present study, higher natriuretic peptide concentrations (on the log scale) were related to malnutrition (negative association with ICW/BW) and/or overhydration (positive association with ECW/BW), additively and independently from each other. Importantly, this relation was independent of the cardiac history of the patient. Nonetheless, patients with a history of cardiac disease, patients with higher systolic blood pressure, as well as those who have been on dialysis for a longer period of time, had on average higher NT-proBNP concentrations. Taken together, our data suggests that elevations in NT-proBNP can be explained by abnormalities in a patient's BC and/or by the presence of cardiac disease. This is in agreement with earlier data regarding $\mathrm{ANP}^{30}$ in dialysis patients, in whom, after correction for overhydration, ANP concentrations only decreased in patients 
without cardiac disease but remained largely elevated in patients with intrinsic cardiac disease.

The PA is a complex variable due to its composite nature. On the one hand, it is highly correlated with the ratio between ICW and ECW. On the other, it can also be expressed as a linear function of both parameters, instead of only their ratio $\left(\mathrm{R}^{2}\right.$ 0.9). In this sense, lower PA levels may be the results of malnutrition, or overhydration, as well as both of them simultaneously. The present findings suggest that the predictive power of PA alone on cardiac and inflammation biomarkers is comparable to that of ICW and ECW, once taken together. As such, they buttress the value of the PA as a general marker for illness in dialysis patients. Previous studies showed a relation between the PA and mortality in various patient groups, including dialysis patients. ${ }^{3}$ Herein, the PA was independently related to the BNP, NT-proBNP, as well as to cTnT and hsCRP concentrations (under the premise that it is not corrected for NT-proBNP).

cTnT and hsCRP, were found to be related to the PA and the ICW/BW ratio, but not to the ECW/BW ratio suggesting that malnutrition, rather than overhydration is the most likely reason underlying their increased concentrations. The fact that the statistical significance of these associations disappears after adjustment for NTproBNP might be the result of a statistical artefact, resulting from the strong linear association between the $\mathrm{BC}$ and the natriuretic peptides, making the former redundant. We do however not rule out a potential role for NT-proBNP in mediating a body composition effect of cTnT and hsCRP. At any rate, cTnT and (NT-pro)BNP were significantly related, suggesting a relation between increased cardiac wall stress and micro-ischemia. ${ }^{31}$ Of note, increased cTnT concentrations, may occur even in the absence of coronary artery disease in dialysis patients, ${ }^{6,32-34}$ but were found to be related to left ventricular hypertrophy in dialysis patients. ${ }^{35}$ Left ventricular hypertrophy may increase cardiac wall stress and thus the oxygen demand of the ventricular wall. ${ }^{36}$

Throughout the present study the biomarker concentrations, as well as the BC parameters remained relatively stable over time, nevertheless the natriuretic peptide levels were highly correlated with the BC parameters. This suggests that the natriuretic peptide concentrations are, to some degree, modifiable by changing the BC status. Based on current knowledge, it appears prudent to perform detailed 
assessment of the BC, as well as cardiac evaluation, in patients with clearly elevated NT-proBNP concentrations. Additionally, due to the effects of a reduced renal clearance per se on NT-proBNP concentrations, ${ }^{37}$ it is of great importance that appropriate cut-off concentrations for NT-proBNP concentrations in dialysis patients are developed, as was recently attempted by David et al..$^{38}$ At any rate, it would appear sensible to assess cardiac biomarker concentrations at regular points in time, which would serve both as a baseline level, and as a possible tool for intervention and increased clinical vigilance in patients with largely increased values or variations. Finally, this study also confirms the usefulness of the PA as a general indicator for illness in dialysis patients.

A drawback of the study is the relatively small number of patients, and the absence of echocardiographic data. Strong points of the study are the longitudinal design, and the presence of detailed measurements of volume status.

Concluding, in this longitudinal study, we found a significant relation between natriuretic peptides and the BC assessed by multifrequency bioimpedance. Also, cTnT, natriuretic peptides, and hsCRP were significantly related, showing a complex relation between overhydration, malnutrition, inflammation, and cardiac biomarkers in haemodialysis patients.

\section{Acknowledgements.}

We would like to thank Dr. Etienne Michielsen for his help during the initial conception of this study and for providing us with a convenient database, in which patient data could easily be entered and retrieved. We would also like to thank Roche Diagnostics for providing the hs-cTnT reagents used in this study.

\section{References}

1. Wang AY, Wang M, Woo J, Law MC, Chow KM, Li PK, Lui SF, Sanderson JE. A novel association between residual renal function and left ventricular hypertrophy in peritoneal dialysis patients. Kidney Int. 2002;62:639-647

2. Pillon L, Piccoli A, Lowrie EG, Lazarus JM, Chertow GM. Vector length as a proxy for the adequacy of ultrafiltration in hemodialysis. Kidney Int. 2004;66:1266-1271

3. Mushnick R, Fein PA, Mittman N, Goel N, Chattopadhyay J, Avram MM. Relationship of bioelectrical impedance parameters to nutrition and survival in peritoneal dialysis patients. Kidney Int Suppl. 2003:S53-56 


\section{Chapter 6}

4. Apple FS, Murakami MM, Pearce LA, Herzog CA. Multi-biomarker risk stratification of n-terminal pro-b-type natriuretic peptide, high-sensitivity c-reactive protein, and cardiac troponin $t$ and $i$ in end-stage renal disease for all-cause death. Clin Chem. 2004;50:2233-2235

5. deFilippi C, Wasserman S, Rosanio S, Tiblier E, Sperger H, Tocchi M, Christenson R, Uretsky B, Smiley M, Gold J, Muniz H, Badalamenti J, Herzog C, Henrich W. Cardiac troponin t and c-reactive protein for predicting prognosis, coronary atherosclerosis, and cardiomyopathy in patients undergoing long-term hemodialysis. Jama. 2003;290:353-359

6. Sommerer C, Giannitsis E, Schwenger V, Zeier M. Cardiac biomarkers in haemodialysis patients: The prognostic value of amino-terminal pro-b-type natriuretic peptide and cardiac troponin $t$. Nephron Clin Pract. 2007;107:c77-c81

7. Ie EH, Klootwijk PJ, Weimar W, Zietse R. Significance of acute versus chronic troponin t elevation in dialysis patients. Nephron Clin Pract. 2004;98:c87-92

8. Goetze JP, Jensen G, Moller S, Bendtsen F, Rehfeld JF, Henriksen JH. Bnp and n-terminal probnp are both extracted in the normal kidney. Eur J Clin Invest. 2006;36:8-15

9. Diris JH, Hackeng CM, Kooman JP, Pinto YM, Hermens WT, Van Dieijen-Visser MP. Impaired renal clearance explains elevated troponin $\mathrm{t}$ fragments in hemodialysis patients. Circulation. 2004;109:23-25

10. Lowbeer C, Ottosson-Seeberger A, Gustafsson SA, Norrman R, Hulting J, Gutierrez A. Increased cardiac troponin $t$ and endothelin-1 concentrations in dialysis patients may indicate heart disease [in process citation]. Nephrol Dial Transplant. 1999;14:1948-1955

11. Wallace TW, Abdullah SM, Drazner MH, Das SR, Khera A, McGuire DK, Wians F, Sabatine MS, Morrow DA, de Lemos JA. Prevalence and determinants of troponin $t$ elevation in the general population. Circulation. 2006;113:1958-1965

12. Lowbeer C, Stenvinkel P, Pecoits-Filho R, Heimburger O, Lindholm B, Gustafsson SA, Seeberger A. Elevated cardiac troponin $\mathrm{t}$ in predialysis patients is associated with inflammation and predicts mortality. J Intern Med. 2003;253:153-160.

13. Sommerer C, Heckele S, Schwenger V, Katus HA, Giannitsis E, Zeier M. Cardiac biomarkers are influenced by dialysis characteristics. Clin Nephrol. 2007;68:392-400

14. Earthman C, Traughber D, Dobratz J, Howell W. Bioimpedance spectroscopy for clinical assessment of fluid distribution and body cell mass. Nutr Clin Pract. 2007;22:389-405

15. Chamney PW, Kramer M, Rode C, Kleinekofort W, Wizemann V. A new technique for establishing dry weight in hemodialysis patients via whole body bioimpedance. Kidney Int. 2002;61:2250-2258

16. van de Kerkhof J, Hermans M, Beerenhout C, Konings C, van der Sande FM, Kooman JP. Reference values for multifrequency bioimpedance analysis in dialysis patients. Blood Purif. 2004;22:301-306

17. Konings CJ, Kooman JP, Schonck M, Struijk DG, Gladziwa U, Hoorntje SJ, van der Wall Bake AW, van der Sande FM, Leunissen KM. Fluid status in capd patients is related to peritoneal transport and residual renal function: Evidence from a longitudinal study. Nephrol Dial Transplant. 2003;18:797-803

18. Vicente-Martinez M, Martinez-Ramirez L, Munoz R, Avila M, Ventura MD, Rodriguez E, Amato D, Paniagua R. Inflammation in patients on peritoneal dialysis is associated with increased extracellular fluid volume. Arch Med Res. 2004;35:220-224

19. Niebauer J, Volk HD, Kemp M, Dominguez M, Schumann RR, Rauchhaus M, Poole-Wilson PA, Coats AJ, Anker SD. Endotoxin and immune activation in chronic heart failure: A prospective cohort study. Lancet. 1999;353:1838-1842

20. Cheng LT, Tang W, Wang T. Strong association between volume status and nutritional status in peritoneal dialysis patients. Am J Kidney Dis. 2005;45:891-902

21. Chung SH, Heimburger O, Stenvinkel P, Wang T, Lindholm B. Influence of peritoneal transport rate, inflammation, and fluid removal on nutritional status and clinical outcome in prevalent peritoneal dialysis patients. Perit Dial Int. 2003;23:174-183 
22. Sommerer C, Beimler J, Schwenger V, Heckele N, Katus HA, Giannitsis E, Zeier M. Cardiac biomarkers and survival in haemodialysis patients. Eur J Clin Invest. 2007;37:350-356

23. Mingels A, Jacobs L, Michielsen E, Swaanenburg J, Wodzig W, van Dieijen-Visser M. Reference population and marathon runner sera assessed by highly sensitive cardiac troponin $t$ and commercial cardiac troponin $\mathrm{t}$ and $\mathrm{i}$ assays. Clin Chem. 2008

24. Wu AH, Jaffe AS, Apple FS, Jesse RL, Francis GL, Morrow DA, Newby LK, Ravkilde J, Tang WH, Christenson RH, Cannon CP. National academy of clinical biochemistry laboratory medicine practice guidelines: Use of cardiac troponin and b-type natriuretic peptide or n-terminal prob-type natriuretic peptide for etiologies other than acute coronary syndromes and heart failure. Clin Chem. 2007;53:2086-2096

25. Lippi G, Tessitore N, Montagnana M, Salvagno GL, Lupo A, Guidi GC. Influence of sampling time and ultrafiltration coefficient of the dialysis membrane on cardiac troponin i and t. Arch Pathol Lab Med. 2008;132:72-76

26. Konings CJ, Kooman JP, Schonck M, Cox-Reijven PL, van Kreel B, Gladziwa U, Wirtz J, Gerlag PG, Hoorntje SJ, Wolters J, Heidendal GA, van der Sande FM, Leunissen KM. Assessment of fluid status in peritoneal dialysis patients. Perit Dial Int. 2002;22:683-692

27. Barbosa-Silva MC, Barros AJ. Bioelectrical impedance analysis in clinical practice: A new perspective on its use beyond body composition equations. Current opinion in clinical nutrition and metabolic care. 2005;8:311-317

28. Kotanko P, Levin NW, Zhu F. Current state of bioimpedance technologies in dialysis. Nephrol Dial Transplant. 2008;23:808-812

29. Lee JA, Kim DH, Yoo SJ, Oh DJ, Yu SH, Kang ET. Association between serum n-terminal pro-brain natriuretic peptide concentration and left ventricular dysfunction and extracellular water in continuous ambulatory peritoneal dialysis patients. Perit Dial Int. 2006;26:360-365

30. Leunissen KM, Menheere PP, Cheriex EC, van den Berg BW, Noordzij TC, van Hooff JP. Plasma alpha-human atrial natriuretic peptide and volume status in chronic haemodialysis patients. Nephrol Dial Transplant. 1989;4:382-386

31. Sahinarslan A, Guz G, Okyay K, Torer N, Bali M, Sindel S, Cengel A. Brain natriuretic peptide correlates with troponin $\mathrm{t}$ in patients with renal failure. Acta Cardiol. 2007;62:171-176

32. Sharma R, Pellerin D, Gaze DC, Shah JS, Streather CP, Collinson PO, Brecker SJ. Dobutamine stress echocardiography and cardiac troponin $t$ for the detection of significant coronary artery disease and predicting outcome in renal transplant candidates. Eur J Echocardiogr. 2005;6:327-335

33. Obialo CI, Sharda S, Goyal S, Ofili EO, Oduwole A, Gray N. Ability of troponin t to predict angiographic coronary artery disease in patients with chronic kidney disease. Am J Cardiol. 2004;94:834-836

34. deFilippi CR, Thorn EM, Aggarwal M, Joy A, Christenson RH, Duh SH, Jeudy J, Beache G. Frequency and cause of cardiac troponin t elevation in chronic hemodialysis patients from study of cardiovascular magnetic resonance. Am J Cardiol. 2007;100:885-889

35. Duman D, Tokay S, Toprak A, Duman D, Oktay A, Ozener IC, Unay O. Elevated cardiac troponin t is associated with increased left ventricular mass index and predicts mortality in continuous ambulatory peritoneal dialysis patients. Nephrol Dial Transplant. 2005;20:962-967

36. Ritz E, Koch M. Morbidity and mortality due to hypertension in patients with renal failure. Am J Kidney Dis. 1993;21:113-118

37. Madsen LH, Ladefoged S, Corell P, Schou M, Hildebrandt PR, Atar D. N-terminal pro brain natriuretic peptide predicts mortality in patients with end-stage renal disease in hemodialysis. Kidney Int. 2007;71:548-554

38. David S, Kumpers P, Seidler V, Biertz F, Haller H, Fliser D. Diagnostic value of n-terminal pro-btype natriuretic peptide (nt-probnp) for left ventricular dysfunction in patients with chronic kidney disease stage 5 on haemodialysis. Nephrol Dial Transplant. 2008;23:1370-1377 



\title{
CHAPTER 7
}

\section{Renal dysfunction, haemodialysis and the $\mathrm{NT}$-proBNP/BNP ratio}

\begin{abstract}
SUMMARY
Introduction: Recent studies suggest that B-type natriuretic peptide (BNP) and Nterminal B-type natriuretic peptide (NT-proBNP) concentrations are equally dependant on renal function for their clearance. However, the ratio between NT-proBNP and BNP increases with a decreasing glomerular filtration rate (GFR). In patients with severe reductions in GFR, the discrepancies between BNP and NT-proBNP impede the clinical interpretation of these markers. By assessing the NT-proBNP/BNP ratios in end stage renal disease (ESRD) patients receiving haemodialysis treatment, we aim to shed more light on these discrepancies.

Methods: During a six month follow-up we collected blood samples from 32 clinically stable haemodialysis patients. NT-proBNP and BNP concentrations were assessed every 2 months.

Results: The median within-patient range in BNP concentrations was 74.5 (6.4 1317.9) and for NT-proBNP it was $782(44-26756)$. ). These variations correspond to a coefficient of variation (CV) of 42\% (7-149\%) for BNP and 35\% (8-113\%) for NTproBNP during the 6-month follow-up. The median-within patient range in the NTproBNP/BNP ratio was $13(1-104)$, corresponding to a median CV of $39 \%(10-82 \%)$.

Conclusion: The NT-proBNP/BNP ratios in the haemodialysis patients are much higher than those in patients with moderate and severe renal disease not receiving dialysis. In addition, the high degree of variability in NT-proBNP, BNP and their ratio, suggests that these markers are either cleared or produced in different amounts. These findings argue against NT-proBNP and BNP measurements that are aimed at assessing changes in the patient's condition or as a means to therapeutically guide haemodialysis patients.
\end{abstract}

Parts of this chapter have been published in: American Journal of Clinical Pathology 2010; 134 (3) : 516-517

L. Jacobs, A. Mingels, W. Wodzig,

J. Kooman, M. van Dieijen-Visser 


\section{Introduction}

In the general population the use of brain natriuretic peptide (BNP) and Nterminal brain natriuretic peptide (NT-proBNP) measurements have proven to be powerful tools in the diagnosis ${ }^{1}$ and risk stratification ${ }^{2}$ of heart failure. It has even been suggested that patients can benefit from BNP or NT-proBNP guided therapy. ${ }^{3}$ Nonetheless, in patients with a severely reduced renal function there is a large discrepancy between NT-proBNP and BNP values, which could impede the clinical interpretation and utility of these markers. Recent reports suggest that BNP and NT-proBNP concentrations rely equally on the glomerular filtration rate and $^{4}$ predominantly on cardiac pathologies, rather than renal clearance. ${ }^{4,5}$ Nevertheless, reports showing the NT-proBNP/BNP ratios for subjects over a wide range of glomerular filtration rates show that the NT-proBNP/BNP ratio increases with a decreasing glomerular filtration rate (GFR).4,6,7

The discrepancy between NT-proBNP and BNP could impede the clinical interpretation and utility of one or both of these markers. By assessing the NTproBNP/BNP ratios in end stage renal disease (ESRD) patients receiving haemodialysis treatment, we aim to shed more light on the discrepancies between these natriuretic peptides.

\section{Methods}

\section{Patients}

We studied a cohort of 32 clinically stable chronic haemodialysis patients during a six month longitudinal study. The patient population has been described elsewhere in more detail. ${ }^{8}$ Briefly, our patient population consisted of 21 men and 11 women with an average age of 66 years and an average time on dialysis of 33 months. The patients could be divided into a group without $(n=15)$ and with $(n=17)$ a history of cardiovascular disease (CVD), which was considered present when patients had suffered a previous myocardial infarction, had required coronary intervention (e.g. Percutaneous Transluminal coronary angioplasty, Coronary Artery Bypass Grafting) or suffered from congestive cardiac failure. More details about the population can be found elsewhere.9, 10 The study protocol 
was approved by the medical ethical review committee of the University Hospital Maastricht (Medical Ethical committee azM/UM) and the study was conducted in accordance with the ethical principles of the Declaration of Helsinki. All patients provided written informed consent. Blood samples were collected predialysis at the start of the study and subsequently every two months for a period of 6 months. The collected serum and plasma samples were stored at $-80{ }^{\circ} \mathrm{C}$ until analysis.

\section{Biomarkers measurements}

NT-proBNP concentrations were measured using the proBNP assay for the Elecsys 2010 (Roche Diagnostics, Mannheim, Germany). According to the package insert, the limit of detection (LOD) is $0.6 \mathrm{pmol} / \mathrm{L}(1 \mathrm{pmol} / \mathrm{L}=8.457 \mathrm{pg} / \mathrm{mL})$ and the coefficient of variation (CV) at $20.7 \mathrm{pmol} / \mathrm{L}$ is $3.2 \%$ and is $2.3 \%$ at $586 \mathrm{pmol} / \mathrm{L}$. BNP was measured in plasma with the SHIONORIA BNP immunoradiometric assay (Cis-Bio International, Gif-sur-Yvette, France). This kit, according to its package insert, has a LOD of $2.0 \mathrm{pg} / \mathrm{mL}(1 \mathrm{pg} / \mathrm{mL}=0.289 \mathrm{pmol} / \mathrm{L})$ en a within- and betweenrun $\mathrm{CV}$ of $2.7 \%$ and $4.3 \%$ at $22.1 \mathrm{pg} / \mathrm{mL}$ and $21.1 \mathrm{pg} / \mathrm{mL}$ respectively.

\section{Statistics}

Continuous variables are described as median and minimum and maximum value. The range represents the difference between the minimum and maximum value measured within each patient. The statistical analyses were performed using Statistical Package for Social Sciences (SPSS), Version 15.0 for Windows (SPSS Inc., Chicago, IL, USA).

\section{Results}

At baseline (at the first visit) the median BNP and NT-proBNP concentrations were $70.1 \mathrm{pmol} / \mathrm{L}(2.6-864 \mathrm{pmol} / \mathrm{L})$ and $843.8 \mathrm{pmol} / \mathrm{L}$ (70-22601 pmol/L) respectively. The median NT-proBNP/BNP ratio was $16.8(2.2-113.2)$ at baseline. Both BNP and NT-proBNP concentrations varied widely during the six month period within the individual patients. The median within-patient range in BNP concentrations was $74.5(6.4-1317.9)$ and for NT-proBNP it was $782(44-26756)$. These variations 
correspond to a coefficient of variation (CV) of $42 \%$ (7-149\%) for BNP and 35\% (8$113 \%$ ) for NT-proBNP during the 6-month follow-up. These large inter-individual variations are also present in the NT-proBNP/BNP ratio where the median-within patient range was $13(1-104)$, which corresponds to a median CV of $39 \%(10-82 \%)$. Figure 1 visualises the NT-proBNP/BNP ratios measured during the six month study for each of the 32 patients (patients 16-32 have a history of CVD). Note that even the patients showing the lowest ratios, i.e. patients 9,12 and 13 have ratios $>5$ on at least one occasion.

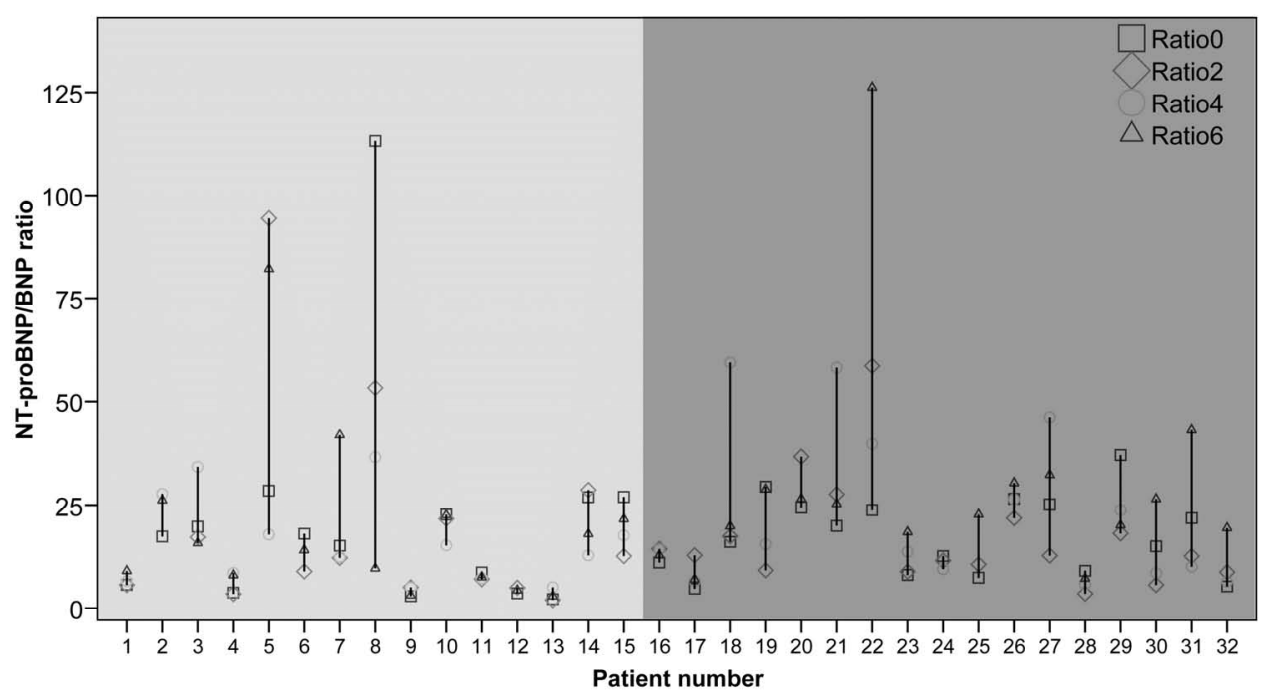

Figure 1. NT-proBNP/BNP ratios measured during the six month follow-up period in 32 haemodialysis patients (patients 16-32 have a history of cardiovascular disease).

\section{Discussion}

One should note that the ratios found here are much higher than those seen in previous reports. In the aforementioned reports by Kemperman et al. ${ }^{7}$ and van Kimmenade et al., ${ }^{4}$ figures are presented that show the NT-proBNP/BNP ratios for subjects over a wide range of glomerular filtration rates. Interestingly, the figures in both papers suggest an exponential increase in NT-proBNP/BNP ratios in patients with GFRs $<30 \mathrm{ml} / \mathrm{min} /\left(1.73 \mathrm{~m}^{2}\right)$. In agreement with this observation are recent data by Srisawasdi et al. ${ }^{6}$ who show that the ratio between NT-proBNP and 
BNP increases exponentially with the stage of renal disease. The high NTproBNP/BNP ratios in patients receiving haemodialysis treatment presented in this report suggested that the GFR dependant exponential increase in the NTproBNP/BNP ratio continues in patients receiving haemodialysis treatment.

Apart from the relatively high NT-proBNP/BNP ratios, figure 1 also clearly visualizes the immense variations seen in each of the patients during the followup. Importantly, these variations were detected in otherwise clinically stable patients. Now it might be argued that a more thorough investigation of the patient's condition (i.e. with echocardiography) would have enabled us to exclude sub-clinically unstable patients. However, the haemodialysis population described here is the kind of population that clinicians encounter in routine clinical practice and the kind of population in which BNP and/or NT-proBNP screening might offer a rapid and unbiased interpretation of the patient's cardiac function. The high degree of variability in the NT-proBNP/BNP ratios measured in the haemodialysis patients suggests different modes of clearance for BNP and NT-proBNP and possibly influences of the dialysis process itself. Indeed, even in healthy patients the clearance of BNP and NT-proBNP occurs by different mechanisms. BNP is mainly removed by the circulating type- $\mathrm{C}$ natriuretic peptide receptor and by neural endopeptidases ${ }^{11}$ (in addition to glomerular filtration) whereas it was recently shown that NT-proBNP is cleared in multiple tissues, albeit that $55-65 \%$ is cleared in renal tissue. ${ }^{12}$ Additionally the dialysis process itself may influence BNP and NT-proBNP concentrations. For instance, several studies have shown large differences between pre and post-dialytic NT-proBNP values, whereby, interestingly, some find elevated levels of NT-proBNP after dialysis ${ }^{13}$ whereas others find lower values. ${ }^{14}$

Future research is needed to identify the underlying mechanisms behind the strongly elevated NT-proBNP ratios. More in general, it would be prudent to investigate the reasons behind the strongly elevated NT-proBNP/BNP ratios, before using NT-proBNP and BNP measurements as a means of assessing changes in the patient's condition or as a means to therapeutically guide patients with strongly reduced renal functions. 


\section{References}

1. McCullough PA, Nowak RM, McCord J, Hollander JE, Herrmann HC, Steg PG, Duc P, Westheim A, Omland T, Knudsen CW, Storrow AB, Abraham WT, Lamba S, Wu AH, Perez A, Clopton P, Krishnaswamy P, Kazanegra R, Maisel AS. B-type natriuretic peptide and clinical judgment in emergency diagnosis of heart failure: Analysis from breathing not properly (bnp) multinational study. Circulation. 2002;106:416-422.

2. Bibbins-Domingo K, Gupta R, Na B, Wu AH, Schiller NB, Whooley MA. N-terminal fragment of the prohormone brain-type natriuretic peptide (nt-probnp), cardiovascular events, and mortality in patients with stable coronary heart disease. Jama. 2007;297:169-176

3. Jourdain P, Jondeau G, Funck F, Gueffet P, Le Helloco A, Donal E, Aupetit JF, Aumont MC, Galinier M, Eicher JC, Cohen-Solal A, Juilliere Y. Plasma brain natriuretic peptide-guided therapy to improve outcome in heart failure: The stars-bnp multicenter study. J Am Coll Cardiol. 2007;49:1733-1739

4. van Kimmenade RR, Januzzi JL, Jr., Bakker JA, Houben AJ, Rennenberg R, Kroon AA, Crijns HJ, van Dieijen-Visser MP, de Leeuw PW, Pinto YM. Renal clearance of b-type natriuretic peptide and amino terminal pro-b-type natriuretic peptide a mechanistic study in hypertensive subjects. J Am Coll Cardiol. 2009;53:884-890

5. Niizuma S, Iwanaga Y, Yahata T, Tamaki Y, Goto Y, Nakahama H, Miyazaki S. Impact of left ventricular end-diastolic wall stress on plasma b-type natriuretic peptide in heart failure with chronic kidney disease and end-stage renal disease. Clin Chem. 2009;55:1347-1353

6. Srisawasdi P, Vanavanan S, Charoenpanichkit C, Kroll MH. The effect of renal dysfunction on bnp, nt-probnp, and their ratio. Am J Clin Pathol. 2010;133:14-23

7. Kemperman $\mathrm{H}$, van den Berg M, Kirkels H, de Jonge N. B-type natriuretic peptide (bnp) and nterminal probnp in patients with end-stage heart failure supported by a left ventricular assist device. Clin Chem. 2004;50:1670-1672

8. Jacobs LH, van de Kerkhof J, Mingels AM, Kleijnen VW, van der Sande FM, Wodzig WK, Kooman JP, van Dieijen-Visser MP. Haemodialysis patients longitudinally assessed by highly sensitive cardiac troponin $\mathrm{t}$ and commercial cardiac troponin $\mathrm{t}$ and cardiac troponin $\mathrm{i}$ assays. Ann Clin Biochem. 2009

9. Jacobs LH, van de Kerkhof J, Mingels AM, Kleijnen VW, van der Sande FM, Wodzig WK, Kooman JP, van Dieijen-Visser MP. Haemodialysis patients longitudinally assessed by highly sensitive cardiac troponin $\mathrm{t}$ and commercial cardiac troponin $\mathrm{t}$ and cardiac troponin $\mathrm{i}$ assays. Ann Clin Biochem. 2009;46:283-290

10. Jacobs LH, van de Kerkhof JJ, Mingels AM, Passos VL, Kleijnen VW, Mazairac AH, van der Sande FM, Wodzig WK, Konings CJ, Leunissen KM, van Dieijen-Visser MP, Kooman JP. Inflammation, overhydration and cardiac biomarkers in haemodialysis patients: A longitudinal study. Nephrol Dial Transplant. 2010;25:243-248

11. Martinez-Rumayor A, Richards AM, Burnett JC, Januzzi JL, Jr. Biology of the natriuretic peptides. Am J Cardiol. 2008;101:3-8

12. Palmer SC, Yandle TG, Nicholls MG, Frampton CM, Richards AM. Regional clearance of aminoterminal pro-brain natriuretic peptide from human plasma. Eur J Heart Fail. 2009

13. Sommerer C, Heckele S, Schwenger V, Katus HA, Giannitsis E, Zeier M. Cardiac biomarkers are influenced by dialysis characteristics. Clin Nephrol. 2007;68:392-400

14. Madsen LH, Ladefoged S, Corell P, Schou M, Hildebrandt PR, Atar D. N-terminal pro brain natriuretic peptide predicts mortality in patients with end-stage renal disease in hemodialysis. Kidney international. 2007;71:548-554 


\section{CHAPTER 8}

General discussion 


\section{General discussion}

Cardiovascular diseases (CVD) are among the most common causes of death in the western world and account for over $30 \%$ of all deaths. ${ }^{1,2}$ Over the years a number of accurate and sensitive biochemical markers have been introduced that have greatly advanced the diagnosis and risk stratification in patients suffering from CVD. Among the most prominent of these markers are the cardiac troponins (cTns) and the brain natriuretic peptides (BNPs), which have revolutionized the diagnosis and risk stratification of acute coronary syndromes (ACS) and congestive heart failure (CHF), respectively. ${ }^{3,4}$ In this thesis we have described several conditions that can influence the concentrations of these markers and that can interfere with their diagnostic potential. For BNP and NT-proBNP, we longitudinally investigated the presence of elevated levels in end-stage renal disease (ESRD) patients. Moreover we investigated the relationship between the cardiac biomarkers, inflammation and the body composition (volume status). For the cTns we investigated their release in conditions where acute irreversible myocardial damage is unlikely to play an important role. We used a recently developed, highly sensitive cTnT assay to study the cTn serum concentrations in healthy subjects, patients with ESRD, patients suffering from acute dyspnea and in (otherwise healthy) subjects subjected to strenuous exercise. Moreover, we studied the release of cTn from cultured cardiomyocytes that were subjected to ischemia (anoxia + glucose deprivation) and electromechanical stimulation (tachypacing). This chapter aims to discuss the scientific and clinical relevance of our findings and offer directions towards future research.

\section{Highly sensitive cardiac troponin measurements}

Recently, a number of cTn assays with the ability to measure the $99^{\text {th }}$ percentile reference value with a coefficient of variation $(\mathrm{CV})$ below $10 \%$ have been introduced. These highly sensitive assays have enabled the acquisition of previously unobtainable information about the cTn concentrations in healthy subjects. For example, several studies have shown significantly higher cTn (both $\mathrm{T}$ and I) concentrations in male than in female subjects. ${ }^{5-9}$ Moreover, the highly sensitive measurements have revealed a significant amount of biological variability in cTn concentrations in otherwise healthy subjects. ${ }^{10,11}$ As recently summarized by 
our group (E. Cardinaels et al., submitted) the sensitive measurements also lead to a considerable heterogeneity in the $99^{\text {th }}$ percentile cut-off values that are reported. A major cause for this heterogeneity can be brought back to differences in the composition of the "healthy" reference population. A more stringent selection of "healthy subjects" leads to lower cTn concentrations in the reference population and a lower $99^{\text {th }}$ percentile (E. Cardinaels et al., submitted). Note that this is in line with recent findings showing previously undetectable cTn concentrations to be associated with structural heart disease and subsequent risk for all-cause mortality in the general population ${ }^{12}$ and in subjects without overt cardiovascular disease. ${ }^{13}$ From the above we can conclude that a great deal of knowledge concerning the cTn concentrations in healthy subjects has been (and will be) gathered with the highly sensitive assay. Most of this knowledge, notably, the presence of intraindividual variations and gender specific reference values, was unknown when the 99th percentile was first introduced as the cut-off value for the diagnosis of AMI. Considering this newfound knowledge it would be wise to investigate if the 99th percentile cut-off value is up for revision.

In defining new/alternative diagnostic cut-off values for cTn in the high-sensitive troponin era a number considerations need to be taken into account. First of all, there should be clear (preferably internationally standardized) criteria for the selection of a "reference population" whereby gender, age, ethnicity and sample size should be described. Moreover, stringent criteria, based on, questionnaires, laboratory parameters and perhaps ECG or cardiac imaging techniques should be taken into account. The difficulty and the degree of screening required can be appreciated from a recent publication that shows that even an 8-minute stress test can lead to significant increases in cTnI, as measured with an ultrasensitive cTnI assay. ${ }^{14}$ These increases $(>1.3 \mathrm{pg} / \mathrm{mL} \mathrm{cTnI})$, although below the 99th percentile, independently predicted the presence of ischemia (as measured by nuclear perfusion imaging).${ }^{14}$ Together with the novel findings on the biological variability in the cTn values in healthy subjects, ${ }^{10,11}$ future diagnostic cut-off criteria may rely more heavily on changing patterns as opposed a single cut-off value. A potential approach to incorporate the biological variation into the diagnosis of AMI could come from the use of reference change values (RCV). ${ }^{15}$ The RCV describes the change in a concentration between two time points, than can be perceived as 
significant, taking into account both the analytical and the individual (biological) variations and is calculated as follows:

$$
R C V=z \times \sqrt{2} \times \sqrt{C V_{A}^{2}+C V_{I}^{2}}
$$

wherein $\mathrm{z}$ is the $\mathrm{z}$ score, which can be set at the desired level of statistical significance. The analytical variation is described by the $C V_{A}$ and the individual (biological) variation by the $\mathrm{CV}_{\mathrm{I} .}{ }^{16}$ To date, there are only a few studies that investigated the RCV values for $\mathrm{cTnT}^{10}$ and $\mathrm{CTnI}^{11}$ in healthy subjects and more studies are needed to examine the strengths and weaknesses of using RCV values for the diagnosis of AMI. Similarly as for determining the 99th percentile cut-off value, the $\mathrm{CV}_{\text {I }}$ for cTn can vary from population to population and can depend on the sampling time-intervals. For example, it has to be investigated if the variations in the cTn measurements seen in dialysis patients, such as shown in chapter 2 and by others ${ }^{17}$ are comparable to those in "healthy subjects" and if they are diagnostically relevant. So, in order to define the biological variations, clear rules need to be established with respect to the inclusion of subjects, sampling times, storage etc. Moreover, the variations in otherwise healthy subjects may vary from those in diseased populations. In any case, the introduction of increasingly sensitive cTn assays has (and will) enabled a more detailed picture of the biological variations in cTn and possibly a better differentiation between healthy and diseased subjects. As a result the sensitive cTn assays are likely to improve the early diagnosis of AMI, as is illustrated by a recent study by Reichlin et al. showing an increased diagnostic performance 3 hours after the onset of AMI with sensitive cTn assays. ${ }^{18}$

Apart from the diagnostic value, the highly sensitive cTn assays are likely to improve the risk stratification in various patient populations. For example, as shown in chapter 3 , the hs-cTnT assay enabled the detection of circulating troponin in the majority of patients with acute dyspnea and low levels of cTnT were of prognostic value. Similarly the hs-cTnT assay enabled the detection of circulating troponin in the majority of patients with chronic HF and stable coronary artery disease (CAD) and was found to be prognostic in these patients. ${ }^{19,} 20$ 
Notwithstanding the diagnostic and prognostic value of the new, highly sensitive cTn assays a number of questions still remain, that cannot be answered, merely by an increasing sensitivity. Two examples of such questions have been extensively studied by our group and pertain to the presence of elevated cTn levels in end stage renal disease (ESRD) and after strenuous exercise. In these conditions, the answers perhaps lie with a more precise understanding of the molecular forms of cardiac troponin that are released into the bloodstream.

\section{When, where and how are the cardiac troponins released}

In Chapter 5 of this thesis we aimed to investigate the release of cTn after strenuous exercise by studying the release kinetics of cTn and its molecular forms from cultured cardiomyocytes that were subjected to electric-field stimulation at 3 $\mathrm{Hz}$ (tachypacing). Moreover, we compared the release characteristic of the cTns in response to the tachypacing with the release after ischemic damage (as induced by anoxia + glucose deprivation).

Using our models for ischemia and tachypacing in Hl-1 cardiomyocytes we found that the release of cTnI and cTnT was always associated with a concomitant release of the cytosolic protein, and known marker for cell-death: lactate dehydrogenase $(\mathrm{LDH})$. Based on these results, it therefore seems that the cTns are only released upon irreversible cell-death. However, before LDH was released, there was already a significant decrease in the cellular content of the cTns in response to ischemia (50\% for cTnI and 20\% for cTnT) and tachypacing (37\% for cTnI and $21 \%$ for cTnT). The exact mechanism behind this intracellular decrease is unknown, but could, in part, be due to intracellular degradation as the ischemia treatment revealed the increasing presence of lower MW cTnI and cTnT fragments with progressive lengths of treatment. Interestingly, no time dependent changes in the molecular forms of cTnI or cTnT could be detected upon tachypacing. Moreover, the relative amount of cTnT versus cTnI increases by a factor 16 after 24 hours of ischemia treatment. Upon tachypacing, there was hardly any increase in the relative amount of cTnT versus cTnI. These findings suggest clear differences in the cellular fate of the cTns in reponse to ischemia or tachypacing.

As mentioned above, with respect to the release of cTn into the culture medium, we find that not only the release upon ischemia, but also after tachypacing is 


\section{Chapter 8}

related to irreversible cellular death. These findings conflict with a study by Hessel et al. ${ }^{21}$ who showed the release of cTnI from viable cardiomyocytes by stimulation of stretch-responsive integrins. We should note, however, that tachypacing and integrin stimulation are very different approaches towards mimicking mechanical stretch and results may not be comparable. It would be interesting to compare tachypacing and integrin stimulation directly in future studies. Moreover, the concomitant release of LDH with the cTns, may not necessarily be caused by irreversible cell-death. Recently, Hickman et al..$^{22}$ offered an interesting explanation for the release of cTn from viable, non-necrotic cardiomyocytes. According to their hypothesis, blebs can form on the plasma membrane of cardiomyocytes in response to ischemia. These blebs, can either be reabsorbed, or release their content into the circulation. When the blebs release their content, cTn levels in a patient's blood will rise, whilst the cardiomyocytes remain viable (if the ischemic damage is not too large). If this hypothesis is correct, than the concomitant release of LDH with the cTns is not necessarily the result of irreversible cellular damage. Future studies, should therefore include morphological studies, using electron microscopy to investigate the presence or absence of membrane blebbing under various experimental conditions.

With respect to the release characteristics of the cardiac troponins we do find some interesting differences between the ischemia and the tachypacing treated cultures. In the ischemia treated cells we find that the relative amount of cTnI within the cells decreases slightly compared to LDH and strongly compared to cTnT. As a result the relative amount of cTnT versus cTnI increases by a factor 16 after 24 hours of pacing. Upon tachypacing, there is hardly any increase in the relative amount of cTnT versus cTnI. The release of cTnI in response to ischemia was also more pronounced in the first hours after onset of ischemia and suggests that cTnI is release before cTnT after ischemic damage. Future studies, using equally (highly) sensitive cTnI and cTnT assays are needed to test this in AMI patients.

With respect to the different molecular forms of $\mathrm{cTn}$ that are released in response to ischemic damage and tachypacing our results are ambiguous. On the one hand we find the formation of fragmented forms of cTnI and cTnT in the cell lysates of ischemia treated cells (and not in tachypaced cells). On the other hand we only detect intact $\mathrm{cTnI}$ and $\mathrm{cTnT}$ in the culture medium of the treated cells. This could 
however be due to the relatively low concentration of cTn that in the medium (especially in the early hours of treatment) and studies using more cells or models using isolated animal hearts might results in released cTn concentrations that are more easily blotted. It would additionally be interesting to test for the presence of different molecular forms of cardiac troponin, directly in the serum of marathon runners or in serum from animals that are subject to strenuous exercise. To do so, more sensitive analytical approaches would, however, be necessary as current Western blotting approaches are not sensitive enough to detect cTn in the serum of marathon runners.

\section{Cardiac biomarker measurements in End Stage Renal Disease}

The majority of patients with ESRD suffer from cardiovascular diseases, such as $\mathrm{CHF}$ and most of the patients will die from cardiovascular causes.23-25 The cardiac biomarkers described in this thesis, cTnT, cTnI, BNP and NT-proBNP have greatly advanced the diagnosis of acute coronary syndromes (ACS) and CHF, respectively, in both the general population and ESRD patients., 4, 26-30 However, in the setting of ESRD, cardiac troponin concentrations can be elevated in the absence of apparent cardiac damage or clinical symptoms.26, 29, 31-33 Similarly, BNP and N-terminal proBNP (NT-proBNP) concentrations are virtually always increased in ESRD patients. ${ }^{29}, 30$ The presence of such continuously elevated cardiac troponin, BNP and NT-proBNP concentrations can interfere with their diagnostic and prognostic potential in ESRD patients. ${ }^{34-36}$

With respect to the cardiac troponins we have seen in chapter 2, that the presence of cTn elevations in ESRD patients might be even more frequent than previously thought. We found, that by using a more sensitive cTnT assay more patients had elevated cTnT values at the beginning of our study ( $38 \%$ with the conventional assay versus $94 \%$ with the hs-cTnT assay). Others have similarly found a larger amount of cTnI elevations in ESRD patients by using more sensitive assays. ${ }^{37,}, 38$ Moreover, by using serial measurements we found that several clinically stable ESRD patients had cTn elevations at least once during the 6-month follow-up (81\%, $100 \%$ and $28 \%$ according to the cTnT, hs-cTnT and cTnI assays respectively). Assessing cTn concentrations at regular points in time would therefore appear as a sensible tool to increase clinical vigilance for the presence of myocardial damage 
and as a means for possible intervention. This is in agreement with previous studies which provided evidence for the increased ability of serial versus single measurements to identify patients at risk for an event. ${ }^{39-43}$

For BNP and NT-proBNP the use of serial measurements might also be used to determine baseline levels, and as a possible tool for intervention and increased clinical vigilance in patients with largely increased values or variations. Importantly, our results in chapter 6 show that the BNP and NT-proBNP concentrations might also be used to investigate the volume status in patients undergoing hemodialysis treatment. Throughout the study, BNP and NT-proBNP were highly correlated with the volume status. This suggests that the natriuretic peptide concentrations are, to some degree, modifiable by changing the volume status. We should note that the volume status is just one of many possible influences on the natriuretic peptide levels. For example, the dialysis process itself may influence BNP and NT-proBNP concentrations, whereby, some find elevated levels of NT-proBNP after dialysis ${ }^{44}$ and others find lower values. ${ }^{30}$ Notwithstanding all these influences it is important to note that BNP and NTproBNP remain associated with cardiovascular disease and all-cause mortality and their measurement remains of importance for diagnosis and risk stratification in ESRD patients. ${ }^{29,} 30$ However, the optimal cut-off values are significantly higher ${ }^{35}$ in ESRD patients and future studies are needed to develop appropriate cut-off concentrations for BNP and NT-proBNP in these patients.

\section{Concluding remarks}

The work described in this thesis began in June 2007. At that point, the cTns were already firmly established as the most important biochemical markers of ischemic cardiac damage, even though the cTn assays did not meet the analytical criteria required by current guidelines for the diagnosis of AMI. ${ }^{3}$ Since that time, several new assays, among them the hs-cTnT assay that is used throughout this thesis, have been introduced. The increased sensitivity has enabled the acquisition of previously unobtainable information about the cTn concentrations in healthy subjects. However, as with many technological advances, the increased sensitivity 
comes with new challenges and the measurability of cTn in virtually all tested subjects will call for new approaches in defining proper diagnostic cut-off levels. Moreover, apart from the diagnosis of AMI, recent studies are showing that CTnT concentrations well below the $9^{\text {th }}$ percentile are far from benign. In healthy and diseased, in young and old, when it comes to defining what constitutes "healthy cTn concentrations" the correct answer seems to be: less.

While increasing the sensitivity of the cTn assays is a worthwhile endeavor, it will not give insight into the possible differences in the release of cTn between various conditions, such as AMI, strenuous exercise and ESRD. To do so, future research, like that described in chapter 5 of this thesis, that are aimed at identifying specific, disease related differences in the release kinetics of cTn (or its molecular forms) is needed. In turn, this can enable the development of immunoassays with the ability to pinpoint the underlying reason behind the elevated cTn levels and drive the medical community towards harnessing the full diagnostic potential of the cardiac troponins.

\section{References}

1. Roger VL, Go AS, Lloyd-Jones DM, Adams RJ, Berry JD, Brown TM, Carnethon MR, Dai S, de Simone G, Ford ES, Fox CS, Fullerton HJ, Gillespie C, Greenlund KJ, Hailpern SM, Heit JA, Ho PM, Howard VJ, Kissela BM, Kittner SJ, Lackland DT, Lichtman JH, Lisabeth LD, Makuc DM, Marcus GM, Marelli A, Matchar DB, McDermott MM, Meigs JB, Moy CS, Mozaffarian D, Mussolino ME, Nichol G, Paynter NP, Rosamond WD, Sorlie PD, Stafford RS, Turan TN, Turner MB, Wong ND, Wylie-Rosett J. Heart disease and stroke statistics--2011 update: A report from the american heart association. Circulation. 2011;123:e18-e209

2. Vaartjes I, van Dis I, Visseren F, Bots M. Hart- en vaatziekten in nederland 2010, cijfers over leefstijl- en risicofactoren, ziekte en sterfte. Den Haag: Nederlandse Hartstichting 2010.

3. Thygesen K, Alpert JS, White HD. Universal definition of myocardial infarction. J Am Coll Cardiol. 2007;50:2173-2195

4. Maisel AS, Krishnaswamy P, Nowak RM, McCord J, Hollander JE, Duc P, Omland T, Storrow AB, Abraham WT, Wu AH, Clopton P, Steg PG, Westheim A, Knudsen CW, Perez A, Kazanegra R, Herrmann HC, McCullough PA. Rapid measurement of b-type natriuretic peptide in the emergency diagnosis of heart failure. N Engl J Med. 2002;347:161-167.

5. Mingels A, Jacobs L, Michielsen E, Swaanenburg J, Wodzig W, van Dieijen-Visser M. Reference population and marathon runner sera assessed by highly sensitive cardiac troponin $\mathrm{t}$ and commercial cardiac troponin $t$ and $i$ assays. Clin Chem. 2009;55:101-108

6. Saenger AK, Beyrau R, Braun S, Cooray R, Dolci A, Freidank H, Giannitsis E, Gustafson S, Handy B, Katus H, Melanson SE, Panteghini M, Venge P, Zorn M, Jarolim P, Bruton D, Jarausch J, Jaffe AS. Multicenter analytical evaluation of a high-sensitivity troponin $\mathrm{t}$ assay. Clin Chim Acta. 2011;412:748-754 


\section{Chapter 8}

7. Giannitsis E, Kurz K, Hallermayer K, Jarausch J, Jaffe AS, Katus HA. Analytical validation of a high-sensitivity cardiac troponin $\mathrm{t}$ assay. Clin Chem. 2010;56:254-261

8. Clerico A, Fortunato A, Ripoli A, Prontera C, Zucchelli GC, Emdin M. Distribution of plasma cardiac troponin i values in healthy subjects: Pathophysiological considerations. Clin Chem Lab Med. 2008;46:804-808

9. Prontera C, Fortunato A, Storti S, Mercuri A, Boni C, Zucchelli GC, Emdin M, Clerico A. Evaluation of analytical performance of advia ${ }^{\circledR}$ tni ultra immunoassay and comparison with access ${ }^{\circledR}$ accutni(tm) method. Immuno-analyse \& Biologie Spécialisée. 2008;23:311-318

10. Vasile VC, Saenger AK, Kroning JM, Jaffe AS. Biological and analytical variability of a novel highsensitivity cardiac troponin t assay. Clin Chem. 2010;56:1086-1090

11. Wu AH, Lu QA, Todd J, Moecks J, Wians F. Short- and long-term biological variation in cardiac troponin i measured with a high-sensitivity assay: Implications for clinical practice. Clin Chem. 2009;55:52-58

12. de Lemos JA, Drazner MH, Omland T, Ayers CR, Khera A, Rohatgi A, Hashim I, Berry JD, Das SR, Morrow DA, McGuire DK. Association of troponin t detected with a highly sensitive assay and cardiac structure and mortality risk in the general population. Jama.304:2503-2512

13. Otsuka T, Kawada T, Ibuki C, Seino Y. Association between high-sensitivity cardiac troponin $t$ levels and the predicted cardiovascular risk in middle-aged men without overt cardiovascular disease. Am Heart J.159:972-978

14. Sabatine MS, Morrow DA, de Lemos JA, Jarolim P, Braunwald E. Detection of acute changes in circulating troponin in the setting of transient stress test-induced myocardial ischaemia using an ultrasensitive assay: Results from timi 35. Eur Heart J. 2009;30:162-169

15. Aakre KM, Sandberg S. Can changes in troponin results be useful in diagnosing myocardial infarction? Clin Chem. 2010;56:1047-1049

16. Omar F, van der Watt GF, Pillay TS. Reference change values: How useful are they? J Clin Pathol. 2008;61:426-427

17. Hill SA, Cleve R, Carlisle E, Young E, McQueen MJ. Intra-individual variability in troponin $\mathrm{t}$ concentration in dialysis patients. Clin Biochem. 2009;42:991-995

18. Reichlin T, Hochholzer W, Bassetti S, Steuer S, Stelzig C, Hartwiger S, Biedert S, Schaub N, Buerge C, Potocki M, Noveanu M, Breidthardt T, Twerenbold R, Winkler K, Bingisser R, Mueller C. Early diagnosis of myocardial infarction with sensitive cardiac troponin assays. $N$ Engl J Med. 2009;361:858-867

19. Latini R, Masson S, Anand IS, Missov E, Carlson M, Vago T, Angelici L, Barlera S, Parrinello G, Maggioni AP, Tognoni G, Cohn JN. Prognostic value of very low plasma concentrations of troponin $\mathrm{t}$ in patients with stable chronic heart failure. Circulation. 2007;116:1242-1249

20. Omland T, de Lemos JA, Sabatine MS, Christophi CA, Rice MM, Jablonski KA, Tjora S, Domanski MJ, Gersh BJ, Rouleau JL, Pfeffer MA, Braunwald E. A sensitive cardiac troponin t assay in stable coronary artery disease. N Engl J Med. 2009;361:2538-2547

21. Hessel MH, Atsma DE, van der Valk EJ, Bax WH, Schalij MJ, van der Laarse A. Release of cardiac troponin i from viable cardiomyocytes is mediated by integrin stimulation. Pflugers Arch. 2008;455:979-986

22. Hickman PE, Potter JM, Aroney C, Koerbin G, Southcott E, Wu AH, Roberts MS. Cardiac troponin may be released by ischemia alone, without necrosis. Clinica chimica acta; international journal of clinical chemistry. 2010;411:318-323

23. U.S. Renal data system, usrds 2007 annual data report: Atlas of chronic kidney disease and endstage renal disease in the united states, national institutes of health, national institute of diabetes and digestive and kidney diseases, bethesda, md, 2007. 2007:192-208 
24. National Institutes of Health; National Institute of Diabetes and Digestive and Kidney Diseases; Bethesda M. U.S. Renal Data System, USRDS 2007 Annual Data Report: Atlas of Chronic Kidney Disease and End-Stage Renal Disease in the United States. 2007:138-154

25. Herzog CA, Ma JZ, Collins AJ. Poor long-term survival after acute myocardial infarction among patients on long-term dialysis. N Engl J Med. 1998;339:799-805

26. Sommerer C, Beimler J, Schwenger V, Heckele N, Katus HA, Giannitsis E, Zeier M. Cardiac biomarkers and survival in haemodialysis patients. Eur J Clin Invest. 2007;37:350-356

27. Khan NA, Hemmelgarn BR, Tonelli M, Thompson CR, Levin A. Prognostic value of troponin $t$ and i among asymptomatic patients with end-stage renal disease: A meta-analysis. Circulation. 2005;112:3088-3096

28. Apple FS, Murakami MM, Pearce LA, Herzog CA. Predictive value of cardiac troponin i and $\mathrm{t}$ for subsequent death in end-stage renal disease. Circulation. 2002;106:2941-2945.

29. Apple FS, Murakami MM, Pearce LA, Herzog CA. Multi-biomarker risk stratification of n-terminal pro-b-type natriuretic peptide, high-sensitivity c-reactive protein, and cardiac troponin $\mathrm{t}$ and $\mathrm{i}$ in end-stage renal disease for all-cause death. Clin Chem. 2004;50:2233-2235

30. Madsen LH, Ladefoged S, Corell P, Schou M, Hildebrandt PR, Atar D. N-terminal pro brain natriuretic peptide predicts mortality in patients with end-stage renal disease in hemodialysis. Kidney Int. 2007;71:548-554

31. Havekes B, van Manen JG, Krediet RT, Boeschoten EW, Vandenbroucke JP, Dekker FW. Serum troponin $\mathrm{t}$ concentration as a predictor of mortality in hemodialysis and peritoneal dialysis patients. Am J Kidney Dis. 2006;47:823-829

32. Aviles RJ, Askari AT, Lindahl B, Wallentin L, Jia G, Ohman EM, Mahaffey KW, Newby LK, Califf RM, Simoons ML, Topol EJ, Berger P, Lauer MS. Troponin t levels in patients with acute coronary syndromes, with or without renal dysfunction. N Engl J Med. 2002;346:2047-2052.

33. deFilippi C, Wasserman S, Rosanio S, Tiblier E, Sperger H, Tocchi M, Christenson R, Uretsky B, Smiley M, Gold J, Muniz H, Badalamenti J, Herzog C, Henrich W. Cardiac troponin t and c-reactive protein for predicting prognosis, coronary atherosclerosis, and cardiomyopathy in patients undergoing long-term hemodialysis. Jama. 2003;290:353-359

34. David S, Kumpers P, Seidler V, Biertz F, Haller H, Fliser D. Diagnostic value of n-terminal pro-btype natriuretic peptide (nt-probnp) for left ventricular dysfunction in patients with chronic kidney disease stage 5 on haemodialysis. Nephrol Dial Transplant. 2008;23:1370-1377

35. Pimenta J, Sampaio F, Martins P, Carvalho B, Rocha-Goncalves F, Ferreira A, Bettencourt P. Aminoterminal b-type natriuretic peptide (nt-probnp) in end-stage renal failure patients on regular hemodialysis: Does it have diagnostic and prognostic implications? Nephron Clin Pract. 2009;111:c182-188

36. Wu AH, Jaffe AS, Apple FS, Jesse RL, Francis GL, Morrow DA, Newby LK, Ravkilde J, Tang WH, Christenson RH, Cannon CP. National academy of clinical biochemistry laboratory medicine practice guidelines: Use of cardiac troponin and b-type natriuretic peptide or n-terminal prob-type natriuretic peptide for etiologies other than acute coronary syndromes and heart failure. Clin Chem. 2007;53:2086-2096

37. Kumar N, Michelis MF, Devita MV, Panagopoulos G, Rosenstock JL. Troponin i levels in asymptomatic patients on haemodialysis using a high-sensitivity assay. Nephrol Dial Transplant. 2010

38. Hickman PE, Koerbin G, Southcott E, Tate J, Dimeski G, Carter A, McGill D, Talaulikar G, Potter JM. Newer cardiac troponin i assays have similar performance to troponin $\mathrm{t}$ in patients with endstage renal disease. Ann Clin Biochem. 2007;44:285-289

39. Roberts MA, Fernando D, Macmillan N, Proimos G, Bach LA, Power DA, Ratnaike S, Ierino FL. Single and serial measurements of cardiac troponin $\mathrm{i}$ in asymptomatic patients on chronic hemodialysis. Clin Nephrol. 2004;61:40-46 


\section{Chapter 8}

40. Ooi DS, Zimmerman D, Graham J, Wells GA. Cardiac troponin t predicts long-term outcomes in hemodialysis patients. Clin Chem. 2001;47:412-417.

41. Wayand D, Baum H, Schatzle G, Scharf J, Neumeier D. Cardiac troponin $t$ and i in end-stage renal failure. Clin Chem. 2000;46:1345-1350.

42. Han JH, Lindsell CJ, Ryan RJ, Gibler WB. Changes in cardiac troponin t measurements are associated with adverse cardiac events in patients with chronic kidney disease. Am J Emerg Med. 2005;23:468-473

43. Miller WL, Hartman KA, Burritt MF, Grill DE, Rodeheffer RJ, Burnett JC, Jr., Jaffe AS. Serial biomarker measurements in ambulatory patients with chronic heart failure: The importance of change over time. Circulation. 2007;116:249-257

44. Sommerer C, Heckele S, Schwenger V, Katus HA, Giannitsis E, Zeier M. Cardiac biomarkers are influenced by dialysis characteristics. Clin Nephrol. 2007;68:392-400 


\section{Summary}

Cardiovascular diseases are among the most common causes of death in the western world and account for over $30 \%$ of all deaths. Over the years, a number of accurate and sensitive biochemical markers have been introduced that have greatly advanced the diagnosis and risk stratification of cardiovascular diseases. The most prominent of these biochemical markers are the cardiac troponins (cTn, either $\mathrm{T}$ or I) and the brain natriuretic peptides (BNP and NT-pro-BNP). These markers have revolutionized the diagnosis and risk stratification of acute coronary syndromes (ACS) and congestive heart failure (CHF) respectively. Notwithstanding these advances, there are several conditions (outside of ACS or CHF) that can influence the concentrations of these markers and that can interfere with their diagnostic and prognostic potential. In the first part of this thesis (chapters 2 to 5) we mainly address the cTn elevations that are found in conditions without any apparent signs of ischemic cardiac damage. The main focus is on addressing the diagnostic implications and the underlying mechanisms of these non-ischemia related cTn elevations. The second part (chapters 6 and 7) will address the factors that influence the plasma and serum concentrations of NT-proBNP and BNP in patients suffering from end-stage renal disease (ESRD) and their diagnostic and prognostic implications.

In Chapter 1 we provide some background information about the topics that are discussed within this thesis. It provides a general introduction on the cTns, their release and their use as biomarkers of ischemic cardiac damage. Moreover, it discusses the presence of cTn elevations in conditions where ischemic cardiac damage is unlikely to play an important role. Particular focus is placed on the release of cTn after strenuous exercise and on the possible mechanisms underlying them. Moreover, we discuss the presence of elevated cTn, BNP and NT-proBNP concentrations in patients suffering from ESRD.

In Chapter 2 we studied the presence of $\mathrm{cTnT}$ and $\mathrm{CTnI}$ elevations in a population of clinically stable ESRD patients. Moreover, we describe the analytical and biological variations in $\mathrm{CTnT}$ and $\mathrm{cTnI}$ measurements in this population. By using a pre-commercial highly sensitive cTnT assay (hs-cTnT) we were able to perform more sensitive and accurate measurements. Moreover, as the hs-cTnT assay 


\section{Summary}

enables an accurate measurement of cTnT concentration in a healthy reference population, it improves the differentiation between "normal" and elevated cTnT concentrations. Our results show, for the first time, that all of the ESRD patients had elevated cTnT concentrations at least once during the follow-up. As elevated cTn concentrations are highly prognostic of adverse events, the use of serial measurements has thus identified additional patients at risk for such events.

In Chapter 3 we investigate the prognostic value of the hs-cTnT assay for both early and long-term mortality in 678 consecutive patients presenting to the emergency department with dyspnea. Our data show that the hs-cTnT assay enables a better risk stratification than the conventional cTnT assay. Moreover, in the subjects with undetectable cTnT concentrations according to the conventional assay (about $50 \%$ of all patients), the hs-cTnT measurements were predicative of both 90-day and 1-year mortality.

Chapter 4 describes the presence of cTn elevations in response to strenuous exercise. We find that over $86 \%$ of the 85 marathon runners had cTnT elevation above the 99th percentile upper reference limit (URL) with the hs-cTnT assay, compared to only $45 \%$ with the conventional cTnT assay. Multiple regression analysis demonstrated marathon experience and age to be significant predictors of post-marathon cTn concentrations.

In Chapter 5 the release characteristics of the cardiac troponins in response to ischemic damage (modeled by anoxia and glucose deprivation) and strenuous exercise (modeled by electric-field stimulation at $3 \mathrm{~Hz}$ (tachypacing)) are studied. The results show that the release of the known marker for cellular membrane integrity lactate dehydrogenase (LDH) precedes or accompanies the release of cTnI and cTnT. This suggests that the cardiac troponins are only released when irreversible cellular damage has occurred. However, before LDH was released there was already a significant decrease in the cellular content of the cTns in response to ischemia (50\% for cTnI and $20 \%$ for cTnT) and tachypacing (37\% for cTnI and 21\% for cTnT). During the ischemic treatments the release of cTnI exceeds that of cTnT. Moreover the ischemia treatment generates fragmented forms of cTnI and cTnT. Upon tachypacing the release kinetics of cTnI and cTnT do not differ strongly and no changes in the generation of fragmented forms occur. 
The second part of this thesis focuses on the factors that can influence the BNP and NT-proBNP concentrations in patients suffering from ESRD and that can complicate the clinical interpretation of these markers. Chapter 6 examines the relationship between parameters describing the patient's body composition, the degree of inflammation and the cardiac biomarker concentrations. Within our population of 44 hemodialysis patients we found that overhydration, expressed as extracellular water (ECS) divided by the body weight (BW) showed a strong positive relation with the BNP and NT-proBNP concentration. Furthermore NTproBNP concentrations were predictive of $\mathrm{cTnT}$ and hsCRP concentrations. The relation between the body composition and the natriuretic peptide concentrations was independent of the cardiac history of the patient and suggests that the natriuretic peptide levels are to some degree modifiable by changing a patient's fluid distribution. Chapter 7 describes the highly increased NT-proBNP/BNP ratio that is found in ESRD patients and suggests that these markers are either cleared or produced in different amounts in patients receiving hemodialysis treatment.

The final chapter, Chapter 8 contains a general discussion of the results described in this thesis and gives directions towards future research. 


\section{Samenvatting}

Hart en vaatziekten zijn verantwoordelijk voor 30\% van alle sterfgevallen in de westerse wereld. Het gebruik van een aantal gevoelige en accurate biochemische merkers heeft ervoor gezorgd dat de diagnostiek en risicostratificatie van hart en vaatziekten de afgelopen jaren sterk is verbeterd. De belangrijkste biochemische merkers zijn cardiaal troponine I en $\mathrm{T}$ ( $\mathrm{cTnI}$ en $\mathrm{cTnT}$ ) en de brain natriuretic peptides (BNP en NT-pro-BNP). Deze merkers hebben de diagnostiek en de risicostratificatie van respectievelijk, acuut coronaire syndroom (ACS) en hartfalen (HF) gerevolutionaliseerd. Er zijn echter een aantal condities (buiten ACS en HF) die de concentraties van de hierboven genoemde biomerkers kunnen beïnvloeden. Hierdoor wordt de interpretatie van veranderingen in de biomerker concentraties bemoeilijkt en wordt de diagnostische en prognostische waarde beïnvloed. In het eerste deel van dit proefschrift (hoofdstuk $2 \mathrm{t} / \mathrm{m}$ ) gaan wij met name in op de cTn verhogingen die gevonden zijn in condities waarbij geen duidelijke aanwijzingen voor ischemische hartschade zijn. Hierbij is vooral aandacht besteed aan de diagnostische implicaties en de mechanismen die ten grondslag liggen aan de cTn verhogingen zonder duidelijke ischemische hartschade. Het tweede deel van dit proefschrift (hoofdstuk 6 en 7) gaat vooral in op de factoren die de BNP- en NTproBNP concentraties bij patiënten met terminale nierinsufficiëntie (die nierdialyse ondergaan) kunnen beïnvloeden, alsmede de diagnostische en prognostisch implicaties hiervan.

Hoofdstuk 1 geeft de nodige achtergrondinformatie over de onderwerpen die in dit proefschrift worden behandeld. Het geeft een algemene introductie over de cardiale troponines (cTns), hoe ze vrijkomen na hartschade en hoe ze gebruikt worden als biomerkers van ischemische hartschade. Daarnaast beschrijven we de aanwezigheid van cTns verhogingen in condities waar ischemische hartschade onwaarschijnlijk is. In het bijzonder wordt ingegaan op de vrijlating van cTn na zware inspanning en op de mogelijke mechanismen die hieraan ten grondslag liggen. Verder gaan we in op de aanwezigheid van verhoogde cTn-, BNP- en NTproBNP concentraties bij patiënten met terminale nierinsufficiëntie.

In Hoofdstuk 2 onderzochten we de aanwezigheid van cTnT en cTnI verhogingen in een populatie van klinisch stabiele patiënten met terminale nierinsufficiëntie. 
Bovendien beschrijven we de analytische en biologische variaties in de cTnT en cTnI concentraties bij deze patiënten. Door gebruik te maken van een precommerciële, zeer gevoelige cTnT meetmethode (hs-cTnT) waren we in staat om onze metingen gevoeliger en nauwkeuriger uit te voeren. Bovendien stelt de hscTnT meetmethode ons in staan om nauwkeurig de cTnT concentraties in een gezonde referentie-populatie te meten. Hierdoor kan er op een betere manier onderscheid worden gemaakt tussen "normale" en verhoogde cTnT concentraties. Uit onze resultaten blijkt dat alle patiënten met terminale nierinsufficiëntie minstens 1 keer gedurende de loop van de studie verhoogde cTnT concentraties hebben. Omdat verhoogde cTn concentraties voorspellend zijn voor een hogere mortaliteit, kunnen er door het gebruik van seriële metingen patiënten worden geïdentificeerd met een verhoogd risico op overlijden.

In hoofdstuk 3 onderzoeken we de prognostische waarde van de hs-cTnT meetmethode voor zowel korte als lange termijn mortaliteit bij 678 patiënten met dyspnoe (kortademigheid) als voornaamste klacht. Uit de resultaten blijkt dat de hs-cTnT methode een betere risicostratificatie geeft dan de conventionele cTnT methode. Verder blijkt de toegevoegde waarde van de hs-cTnT methode uit het feit dat de hs-cTnT waarden voorspellend waren voor de 90-dagen en 1-jaars mortaliteit in de groep patiënten die volgens de gewone cTnT methode geen meetbare cTnT concentraties hadden (ongeveer $50 \%$ van alle patiënten).

Hoofdstuk 4 beschrijft de aanwezigheid van cTn verhogingen na zware inspanning (rennen van een marathon). Maar liefst $86 \%$ van de 85 marathonlopers had cTnT verhogingen boven de 99 ste percentiel afkapwaarde met de hs-cTnT methode tegenover slechts $45 \%$ met de conventionele cTnT methode. Met behulp van meervoudige regressie-analyse tonen we aan dat marathon ervaring (eerder gelopen marathons) en leeftijd significante voorspellers zijn voor de post-marathon cTn concentraties.

In Hoofdstuk 5 bestuderen we het vrijkomen van cTn na ischemische schade (gemodelleerd door zuurstofgebrek en glucose deprivatie) en na zware inspanning (gemodelleerd door elektrische stimulatie op $3 \mathrm{~Hz}$ (tachypacing) uit $\mathrm{Hl}-1$ cardiomyocten. De resultaten tonen aan dat het vrijkomen van lactaat dehydrogenase $(\mathrm{LDH})$, een bekende merker voor de cellulaire membraan integriteit, voorafgaand of tegelijkertijd met het vrijkomen van $c T n I$ en $c \operatorname{TnT}$ 
plaatsvindt. Dit suggereert dat de cTns alleen vrijkomen in geval van onomkeerbare cellulaire schade. Echter, nog voordat LDH werd vrijgegeven aan het medium was er al een aanzienlijke daling van de intracellulaire hoeveelheid cTn ten gevolge van ischemie (50\% voor cTnI en $20 \%$ voor cTnT) en tachypacing (37\% voor cTnI en $21 \%$ voor cTnT). Als reactie op de ischemische behandeling blijkt er relatief meer cTnI dan cTnT vrij te komen. Verder gaat de ischemische behandeling gepaard met het ontstaan van gefragmenteerde vormen van cTnI en cTnT. Bij de cellen die getachypaced worden zijn er minder duidelijke verschillen tussen het vrijkomen van cTnT en cTnI, daarnaast nemen we geen veranderingen in het ontstaan van gefragmenteerde vormen waar.

Het tweede deel van dit proefschrift richt zich op de factoren die van invloed kunnen zijn op de BNP- en NT-proBNP concentraties bij patiënten die lijden aan terminale nierinsufficiëntie en die de klinische interpretatie van deze markers kunnen compliceren.

Hoofdstuk 6 beschrijft de relatie tussen de lichaamssamenstelling (mate van over/ondervulling), ontsteking en de cardiale biomerkers. In de 44 onderzochte hemodialysepatiënten blijkt dat de mate van overvulling, uitgedrukt als de hoeveelheid extracellulair water gedeeld door het lichaamsgewicht, een sterke positieve relatie met de BNP- en NT-proBNP concentraties laat zien. Verder blijken de NT-proBNP concentraties voorspellend voor cTnT- en hsCRP (merker voor ontsteking) concentraties. De relatie tussen de mate van overvulling en de BNP- en NT-proBNP concentraties was onafhankelijk van de cardiale voorgeschiedenis van de patiënt en suggereert dat de BNP- en NT-proBNP concentraties, tot op zekere hoogte, modificeerbaar zijn door het aanpassen van de hoeveelheid extracellulair water.

In Hoofdstuk 7 beschrijven we de verhoogde NT-proBNP/BNP ratio's die worden waargenomen bij hemodialyse patiënten. Deze sterk verhoogde ratio suggereert dat BNP en NT-proBNP in verschillende hoeveelheden geklaard of geproduceerd worden in patiënten die hemodialyse ondergaan.

Het laatste hoofdstuk, Hoofdstuk 8 bevat een algemene discussie over de in dit proefschrift beschreven resultaten en worden de mogelijkheden voor toekomstig onderzoek beschreven. 


\section{Dankwoord}

Zonder hulp van anderen had ik dit boekje nooit kunnen schrijven. Nu is de tijd aangebroken om een aantal van deze mensen te bedanken. Daarnaast is dit ook de plek om de mensen te bedanken die werkelijk niets hebben bijgedragen aan dit boekje, maar die mijn leven op een andere manier hebben verrijkt. Mijn promotor prof. dr. Marja van Dieijen-Visser en copromotor dr. Will Wodzig ben ik dankbaar voor beide. Beste Marja, bedankt voor al je hulp, voor je inhoudelijke bijdrage, voor de snelheid waarmee je manuscripten corrigeerde en voor het feit dat ik altijd bij je terecht kon met vragen. Maar meer dan dat wil ik je bedanken voor de fijne tijd in Maastricht, voor alle leuke en leerzame momenten tijdens borrels, reizen en een fotoshoot. Beste Will, dank voor al je hulp bij mijn onderzoek, voor de ontelbare keren dat ik even je kamer kon binnenlopen om een vraag te stellen of om even te klagen over het harde leven van een onderzoeker. Dank voor je goede adviezen over mijn onderzoek en over de opleiding tot klinisch chemicus. Dankzij jou en Marja ben ik klaar om "een vak te gaan leren" en ik ben blij dat ik jullie de komende jaren nog vaak zal blijven zien.

Wie ik gelukkig ook ga blijven zien is Alma. Beste Alma, 4 jaar lang was je mijn partner in crime. Het was fantastisch om met jou samen te werken. Altijd iemand om mee te sparren en om vragen aan te stellen. Ook buiten het lab was het een waar genoegen om jou als collega te hebben. Altijd relaxed, altijd in voor een feestje, en vaak tot in de allerlaatste uurtjes van de partij. Ik vind het echt geweldig om samen met jou te promoveren.

Bianca Pulinx, ik denk met veel plezier terug aan jouw tijd op onze kamer en er zijn vele momenten geweest dat Alma en ik jou hebben gemist. Heel veel succes met jouw promotie en met je nieuwe baan. Pinky Matthew, you made my time as a PhD student into a multicultural experience. I wish you all the best. Eline, jij kwam als laatste onderzoeker bij ons op de kamer en versterkte niet alleen ons onderzoek maar ook onze fashion-sense. Heel veel succes met je onderzoek.

Vincent, topanalist en blot-mentor, bedankt voor de fijne en gezellige samenwerking, en al je hulp bij de experimenten. 
Dr. Douwe de Boer, dank voor alle gesprekken tijdens de pauzes, je interessante verhalen over doping en de discussies die we hadden over de politiek. Dr. Bart de Wit, dank voor de goede gesprekken en je hulp om mij jou opvolger in Den Bosch te maken. Dr. Otto Bekers en dr. Paul Menheere, dank voor jullie interesse in mijn onderzoek. Paul, dank voor de kritische vragen over de kwaliteit van de meetmethoden, die komen mij in mijn nieuwe baan goed van pas. Otto, klinisch chemicus en topacteur, als ik aan jou denk zie ik die Italiaanse kok voor me: I have a suprise for you...fantastisch.

Judith, Petal en Lenneke, dank voor de gezellige lunches, borrels en etentjes. Judith speciaal dank voor alle attente e-mails of sms'jes als Janine of ik iets belangrijks hadden.

De afgelopen jaren heb ik het genoegen gehad om een aantal studenten te mogen begeleiden. Met name Sander Streng en Kevin Gerritsen hebben bergen werk verzet. Dank voor jullie hulp, met name jullie hulp tijdens de nachtelijke experimenten was above and beyond the call of duty.

Mijn voorgangers, Etienne en Jart, bedankt voor de solide troponine basis die jullie gelegd hebben. Onze opvolger Lieke wens ik ook veel succes.

Prof. dr. Jan Glatz wil ik bedanken voor zijn interesse in mijn onderzoek en voor het bieden van de gelegenheid om onderzoek bij de moleculaire genetica uit te voeren. Dr. Robert Schwenk, bedankt voor de fijne samenwerking en alle hulp met de HL-1 cellen.

De nefrologen dr. Jeroen Kooman en Jos van de Kerkhof, dank voor al jullie hulp en voor de goede samenwerking. Met jullie hulp is de basis gelegd voor bijna de helft van de hoofdstukken in dit boek. Jos, ik waardeer het enorm dat je destijds naast je drukke baan tijd maakte om af en toe naar Maastricht te komen.

Sandra van Wijk, het was mij een waar genoegen om met je samen te werken. Tijdens het schrijven hadden we meestal aan één woord genoeg. Hulde voor je vasthoudendheid bij het submittten.

Dr. Valeria Lima Passos, toen ik je vroeg om even naar mijn artikel te kijken hadden we niet verwacht dat er nog zoveel veranderd moest worden. Dank voor al je advies en hulp. 
Gerd-Jan, van de waterstraat in Horst, thuisjongen, vriend, consigliere en nu ook mijn paranimf (zoals ik de jouwe was). Bedankt voor je vriendschap, voor al je hulp en adviezen, voor het feit dat je weet dat ik altijd hetzelfde voor jou zou doen. Ik kan niet wachten op ons kantoor met balkon.

Steven, mijn mede grijze muis, tevens paranimf. Of het nu gaat over het opnieuw indienen van een artikel, het schrijven van een project/artikel/sollicitatiebrief of over het zetten van een simpel bakkie pleur, jij weet mij altijd te enthousiasmeren! Ik hoop dat we het nog vaak uit de hand laten lopen.

Iedereen die ik niet bij naam kan noemen omdat het teveel werk is, omdat er te weinig ruimte is of omdat mijn geheugen mij in de steek laat, dank voor de fantastische tijd in Maastricht. In het bijzonder wil ik de medewerkers van het Klinisch Chemisch Laboratorium in Maastricht bedanken voor de fijne samenwerking, voor de carnavalsvrijdagen en voor jullie ongelooflijk creatief en mooi cadeau. Ook mijn collega Carim promovendi, dank voor de gezellige Papendal cursussen, en voor het feit dat enkele van jullie mij een paar maanden aan het rennen hebben gekregen. Verder wil ik mijn nieuwe collega's van de afdeling Klinische Chemie en Hematologie van het Jeroen Bosch Ziekenhuis bedanken. Binnen een paar weken voelde ik mij al helemaal thuis.

Rik en Annemarie, fijn dat ik af en toe bij jullie kon klagen, bedankt voor het wandelen, de uitjes en voor het plat Horster ver van huis.

Mijn studiegenoten uit Nijmegen: ik hoop dat we de studiereis reünie ieder jaar blijven vol houden. Bas (bijna dr.), Maurice (helemaal directeur), jullie waren (met mij, al zeg ik het zelf) de meest effectieve MLW studenten. Het is altijd leuk om jullie weer te zien.

Mijn vrienden wil ik bedanken voor hun steun en begrip als ik te druk had om af te spreken. Vooral mijn thuisjongens uit Horst: René, Tristan, Geert, Mark, Gerd-Jan en Richard. Dank voor jullie vriendschap, dank voor de mannenweekenden, dank voor alles. Ook dank aan de partners voor de vriendenweekenden, voor de gezelligheid en voor het feit dat jullie Tristan en mij laten uitkuren (gelukkig vallen vrouwen op littekens). 
Pap, mam, Jean-Pierre en Eveline, dank voor jullie steun en interesse. Jean-Pierre, dank voor de leuke game-tijd in Maastricht en de lekkere Japanse maaltijden. Eveline, door onze drukke bezigheden hebben we elkaar de afgelopen jaren niet zoveel gezien, als we elkaar zagen was het altijd leuk. Pap en mam, bedankt dat jullie mij van jongs af aan mijn eigen keuzes lieten maken en het vertrouwen hadden dat het wel goed zou komen. Bedankt voor jullie steun en hulp, bedankt voor alles!

Als laatste wil ik Janine bedanken. Janine, jij bent mijn steun en toeverlaat. Het is fantastisch om bij jou te zijn, je bent mooi, lief en slim. Janine, ik zeg weleens dat ik alles zou inruilen voor een beetje meer; alles behalve jou, want zonder jou is alles minder. 


\section{List of publications}

Jacobs L ${ }^{*}$ van Wijk S*, Eurlings L, van Kimmenade R, Lemmers R, Broos P, Bekers O, Prins M, Crijns H, Pinto $Y$, van Dieijen-Visser M, Brunner-La Rocca HP. Highly sensitive troponin T versus conventional troponin $\mathrm{T}$ testing for risk stratification in patients presenting with acute dyspnea to the emergency department. Accepted for publication in Clinical Chemistry (January 2012 issue). * Equal contribution.

Jacobs L*, van de Kerkhof J*, Mingels A, Lima Passos V, Kleijnen V, Mazairac A, van der Sande F, Wodzig W, Konings C, Leunissen K, van Dieijen-Visser M, Kooman J. Inflammation, overhydration and cardiac biomarkers in haemodialysis patients: a longitudinal study. Nephrology Dialysis Transplantation 2010; 25 (1): 243-248. * Equal contribution.

Jacobs L, Mingels A, Wodzig W, Kooman J, van Dieijen-Visser M. Renal dysfunction, Haemodialysis and the NT-proBNP/BNP ratio. American Journal of Clinical Pathology. 2010; 134 (3): 516-517.

Jacobs L, van de Kerkhof J, Mingels A, Kleijnen V, van der Sande F, Wodzig W, Kooman J, van DieijenVisser M. Haemodialysis patients longitudinally assessed by highly sensitive cardiac troponin $\mathrm{T}$ and commercial cardiac troponin T and cardiac troponin I assays. Annals of Clinical Biochemistry 2009, 46 (4): 283-290.

Mingels A, Jacobs L, Michielsen E, Swaanenburg J, Wodzig W, van Dieijen-Visser M. Reference population and marathon runner sera assessed by highly sensitive cardiac troponin $\mathrm{T}$ and commercial cardiac troponin T and I assays. Clinical Chemistry 2009, 55 (1):101-108.

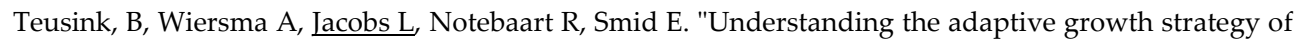
Lactobacillus plantarum by in silico optimisation." PLoS Computational Biology 2009; 5 (6): e1000410.

Mingels A, \acobs L, Kleijnen V, Laufer E, Winkens B, Hofstra L, Wodzig W, van Dieijen-Visser M. Cardiac troponin $\mathrm{T}$ elevations, using highly sensitive assay, in recreational running depend on running distance. Clinical Research in Cardiology 2010; 99 (6) : 385-391

Mingels A, \acobs L, Kleijnen V, Wodzig W, van Dieijen-Visser M. Cystatin C, a marker for renal function after exercise. International Journal of Sports Medicine 2009; 30 (9): 668-671.

Jacobs L, van de Kerkhof J, Mingels A, Kleijnen V, van der Sande F, Wodzig W, Kooman J, van DieijenVisser M. Cardiac biomarkers in dialysis patients: variations during a six month follow up. Nederlands Tijdschrift voor Klinische Chemie en Laboratoriumgeneeskunde 2008; 33: 176-178.

Mingels A, Jacobs L, Michielsen E, Swaanenburg J, Wodzig W, van Dieijen-Visser M. Cardiac and renal markers: reference population versus marathon runners. Nederlands Tijdschrift voor Klinische Chemie en Laboratoriumgeneeskunde 2008; 33: 188-190. 


\section{List of publications}

Jacobs L, Mingels A, van Dieijen-Visser M. Cardiac biomarkers in end-stage renal disease. Renal Diseases (Book 3) 2011, M. Sahay (Ed.), ISBN 979-953-307-705-4, Intech. Accepted for publication.

Jacobs L, Gerritsen K, Schwenk R, Cardinaels E, Wodzig W, Glatz J, van Dieijen-Visser M. Ischemia and mechanical stretch in cultured cardiomyocytes and their varying effects on cardiac troponin release and degradation. In preparation.

Cardinaels E, Mingels A, Jacobs L, Bekers O, van Dieijen-Visser M. A comprehensive review of diagnostic cutoff concentrations for high-sensitivity troponin assays and the challenges that lie ahead. Submitted. 


\section{Curriculum Vitae}

Leo Jacobs werd geboren op 15 mei 1980 te Venray. In 1996 behaalde hij zijn MAVO-diploma aan het Dendron College in Horst. Na een jaar HAVO-4 werd de kans geboden om direct naar VWO-5 door te stromen. Deze kans greep hij met beide handen aan en in 1999 behaalde hij zijn VWO diploma. Na het VWO startte Leo met de studie farmacie aan de Universiteit Utrecht om vervolgens in 2002 Moleculaire levenswetenschappen aan de Radboud Universiteit in Nijmegen te gaan studeren. Zijn afstudeerstages volgde hij bij de computational genomics departement van het CMBI in Nijmegen (onder begeleiding van dr. Ludo Pagie en prof. dr. Martijn Huynen) en bij NIZO food research in Ede (onder begeleiding van prof. dr. Bas Teusink). In 2007 studeerde hij met veel genoegen af en nog voordat hij zijn doctoraal in ontvangst kon nemen was hij begonnen aan zijn promotieonderzoek op het klinisch chemisch laboratorium van het academisch ziekenhuis Maastricht. Daar voerde hij onder begeleiding van zijn promotor prof. Marja van Dieijen-Visser en copromotor dr. Will Wodzig het in dit proefschrift beschreven onderzoek uit. In 2010 ontving Leo een stipendium van de Noyons stichting voor het uitvoeren van een studie naar het vrijkomen van cardiaal troponine $\mathrm{T}$ uit reversibel en irreversibel beschadigde hartspiercellen. De resultaten die hieruit voortvloeiden staan beschreven in dit proefschrift. Momenteel is Leo in opleiding tot klinisch chemicus bij prof. dr. Ron Kusters en dr. Peter van 't Sant in het Jeroen Bosch Ziekenhuis in Den Bosch. 